Uwuas

Torawe

LuBn 





\section{ACIDITY AND GAS INTERCHANGE IN CACTI}

BY

HERBERT M. RICHARDS

Professor of Botany,

Barnard College, Columbia University

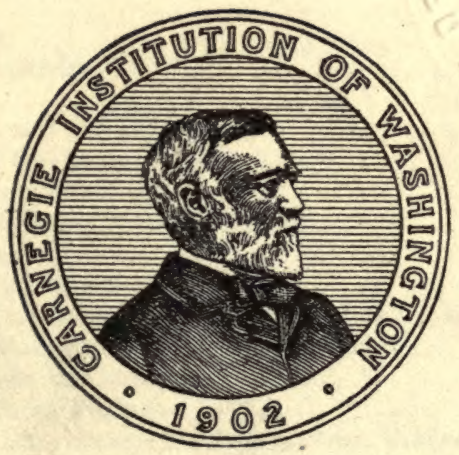

$\frac{1300398}{19 / 5 / 19}$

WASHINGTON, D. C.

Published by the Carnegie Institution of Washington 
CARNEGIE INSTITUTION OF WASHINGTON

Publieation No. 209

Copies of this Book

were first issued

AUG $\$ 11915$

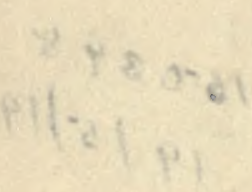

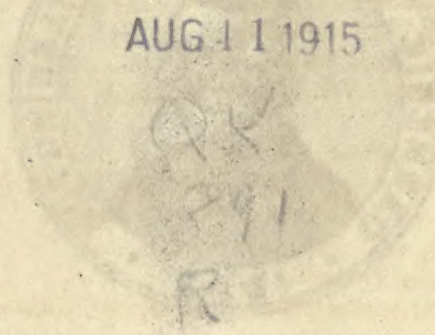

PRESS OF GIBSON BROTHFR, INC.

WASHINGTON, D. C. 


\section{CONTENTS.}

Historical.

Experimental Methods.

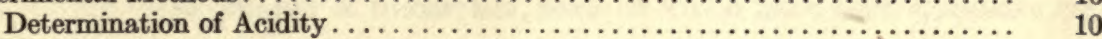

Determination of Respiration by the Pettenkofer Method............... 13

Methods in Gas-interchange Determinations. . . . . . . . . . . . . . . 15

General Methods of Procedure and Precautions.................... 20

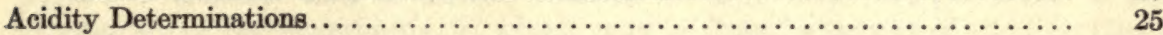

Periodicity in Acidity . . . . . . . . . . . . . . . . . . . . . . . . . 25

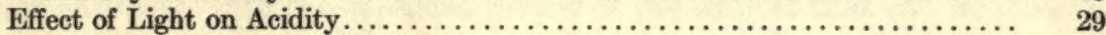

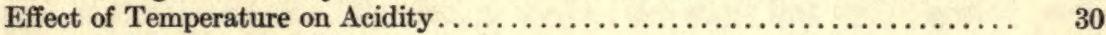

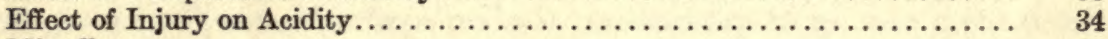

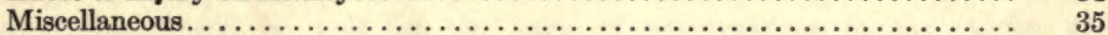

Experimental Data on Acidity Determinations, Tables 7 to $25 \ldots \ldots \ldots \ldots \ldots \ldots$

Evolution of Carbon Dioxide as determined by the Pettenkofer Method........ 47

Normal Respiration. . . . . . . . . . . . . . . . . . . . . . . . . . 47

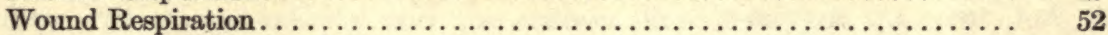

Diurnal Periodicity in relation to Temperature. . . . . . . . . . . . . 53

Experimental Data of Determinations with Pettenkofer Apparatus, Tables 28 to 41 . . $\quad 55$

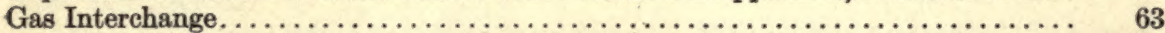

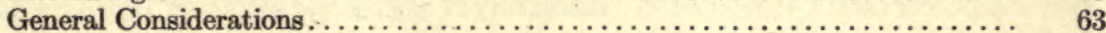

Quantities in Gas Interchange. . . . . . . . . . . . . . . . . . $66 \ldots \ldots$

Temperature Effect. . . . . . . . . . . . . . . . . . . . . . . . . . . . . 68

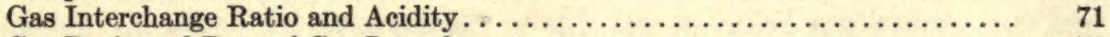

Gas Ratio and Rate of Gas Interchange. . . . . . . . . . . . . . . . . 73

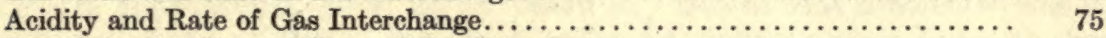

Pure Juice Acidity and Rate of Gas Interchange. . . . . . . . . . . . . 77

Certain Anomalous Cases. . . . . . . . . . . . . . . . . . . . . . . . . . 78

Relation of Gas Ratio to Course of Acidity . . . . . . . . . . . . . . 79

Evolution of Carbon Dioxide in Diffuse Light and Direct Sunlight. . . . . . . . . . 82

Evolution of Carbon Dioxide in the Absence of Oxygen.............. 84

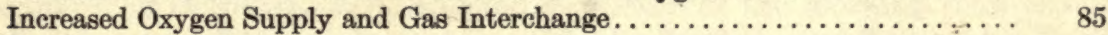

Gas Interchange over Long Periods. . . . . . . . . . . . . . . . . . . . 86

Experimental Data of Gas Interchange Determinations, Tables 53 to $67 \ldots \ldots \ldots \ldots 8$

Summary and Conclusions. . . . . . . . . . . . . . . . . . . . . . . . . . . . 
Digitized by the Internet Archive in 2007 with funding from Microsoft Corporation 


\title{
ACIDITY AND GAS INTERCHANGE IN CACTI.
}

\author{
BY Herbert M. Richards.
}

\section{HISTORICAL.}

That the respiratory activity, or rather the phenomena connected with the evolution of carbon dioxide, in cacti and in other succulents is peculiar and that the acidity of the juices of these plants exhibits periodic rise and fall have been known for a long time. These phenomena have been the subject of a considerable number of researches, some of which have been elaborate and thorough.

Within the last 25 years there have been published the comprehensive papers of Aubert ${ }^{a}$ and of Astruc ${ }^{b}$ dealing directly with the problems of the physiology of the succulents, in which may be found a survey of the literature. These accounts, with the excellent review of the subject that can be found in Czapek's ${ }^{e}$ Biochemie der Pflanzen, as well as the short but well-digested treatment given by Spoehr, ${ }^{d}$ perhaps make it unnecessary to go into great detail, nevertheless it will be well for the sake of convenience to summarize the present state of knowledge concerning the points mentioned above.

The two principal phenomena with which we are concerned, namely, the acidity with its periodicity and the carbon dioxide-oxygen quotient, are, as is now known, intimately connected; but in the earlier literature they were not associated.

It was that remarkably astute investigator, deSaussure, ${ }^{e}$ who first discovered that in a certain cactus form (Opuntia sp.), with which he experimented, the intake of oxygen might, under some circumstances, greatly exceed the output of carbon dioxide. In consequence of this the so-called respiratory quotient, instead of approaching unity, fell far below it. But at that time there was no knowledge of the acidity of the plant juices, let alone its periodicity, so that the significance of this peculiarity was not understood. As to the acidity of succulent plants, we owe the first mention to a casual observation by Benjamin Heyne ${ }^{f}$ in 1819 , who contributed a note regarding the more acid taste of the leaves of Bryophyllum (Cotyledon) calycinum in the morning than late in the afternoon. This original note, with the further contribution by H. F.

\footnotetext{
${ }^{a_{A}}$ Aubert, E. Recherches physiologiques sur les plants grasses: Part 1, Acides organiques, turgescence et transpiration des plantes grasses; part 2, Respiration et assimilation comparées chez les plantes grasses et les végétaux ordinaires. [Thesis.] Paris, 1892. See also: Sur la repartition des acides organiques chez les plantes grasses, Rev. Gen. Bot., vol. 2, p. 369, 1890; Recherches sur la respiration et l'assimilation des plantes grasses, Rev. Gen. Bot., vol. 4, p. 203, 1892; Recherches sur la turgescence et la transpiration des plantes grasses, Ann. Sc. Nat. Bot., series 7, vol. 16, p. 1, 1892.

${ }^{b}$ Astruc, A. Recherches sur l'acidité végétale. Ann. d. Sci. Nat. Bot., series 8, vol. 17, pp. 1-105, 1903.

${ }^{\circ}$ Czapek, F. Einige Biochemische Verhältnisse der Pflanzensäuren. Biochemie der Pflanzen, vol. 2, pp. 446 et seq., 1905.

dSpoehr, H. A. Photochemische Vorgänge bei der Entsäuerung der Succulenten. Biochemische Zeitschrift, vol. 57, p. 95, 1913.

${ }^{e}$ De Saussure, Theod. Recherches chimiques sur la vegetation, p. 64, 1804.

'Heyne, B. Trans. Linn. Soc., vol. II, part 2, p. 213.
} 
Link, is printed in Kraus' $\mathrm{s}^{a}$ paper on the acidity of cell-sap. Link actually tested with litmus paper the juice expressed from the same plant and also other crassulaceous forms, in the morning and in the evening, and so by more definite experimental means corroborated Heyne's report.

It was not until 1875 and later that $\mathrm{A}$. Mayer ${ }^{b}$ published his series of papers on his investigations of the organic acids found among the Crassulaceæ and established the fact that it is malic or isomalic acid that is present in these plants.

We may regard the investigation of de Saussure and the observations of Heyne and of Link as the starting-points from which have come the subsequent researches into the acidity of the succulent plants and their respiratory activity. Indeed, the whole question of the relation of acidity to the evolution of carbon dioxide had its first stimulus in these observations. Historically considered, Liebig's $\mathrm{s}^{c}$ theories find place here. In connection with the disappearance of organic acids in the ripening of fruit, he conceived the idea that these acids were concerned in the upbuilding of carbohydrates by the plant, and constituted a midpoint between carbon dioxide on the one hand and sugars on the other. This point of view was not, indeed, accepted by all, even at the time of its publication, and has since found but little favor, at least among plant physiologists. For a further discussion and more detail concerning the part which the investigations of A. Mayer played in regard to Liebig's theory, reference may be made to Warburg's account ${ }^{d}$ and to Spoehr, loc. cit., in which papers the matter is more fully discussed. It is sufficient to say that practically all of the later investigators have shown Liebig's theory to be untenable.

Kraus, in his paper on the acidity of cell-sap, in general very distinctly states his opinion that the acid is in no way connected with the formation of food substances and that it is a by-product of respiration. He determined that the loss of acid during the day was due to the direct effect of light and had no immediate connection with the true respiratory activity of the tissues. $\mathrm{He}$ regarded the acid as a secondary product of proteid splitting.

De Vries, ${ }^{e}$ in his work on the periodicity of acid formation in succulents, determined that prolonged darkness also results in diminution of acidity and further that exposure to high temperature produces the same effect. He concluded that the splitting up of the acid and its upbuilding are coincident processes, both of which are always taking place. At night the synthesis of the acid is more rapid than its breaking down, and in the day the reverse is true. He also held that no connection exists between the presence or absence of acids and the formation of sugars by the plant.

In many respects Warburg's paper, which followed shortly afterwards, is the most scholarly treatment of the subject that we have. He discusses the his-

\footnotetext{
aKraus, G. Ueber die Wasservertheilung in der Pflanze. IV. Die Acidität des Zellsaftes. Abh. der naturforseh. Ges., Halle, vol. 16, pp. 154-157, 1883.

Mayer, Ad. Landw. Versuchstat., vol. 18, p. 428, 1875; vol. 21, p. 277, 1878; vol. 30, p. 217. 1884; vol. 34, p. $127,1887$.

'Liebig. Chemie in ihrer Anwendung auf Agrikultur und Physiologie, 9th ed., p. 31, 1876.

${ }^{\star}$ Warburg, O. Ueber die Bedeutung der Organischen Säuren für den Lebensprozess der Pflanzen. Untersuch., aus dem Bot., Inst., Tubingen, vol. 2, p. 57, 1886.

'De Vries, H. Ueber die periodische Sảurebildung der Fettpflanzen. Bot. Zeit., vol. 42, p. 337, 1884. Ibid., Ueber die Periodicität im Säuregehalt der Fettpflanzen. Verslagen en Medeedlingen der Kononkl. Akad. van Wetenschapen. Afd. Naturkunde Reeks, Deil 1, 1884. Abstract Just Bot. Jahrb., vol. 1, p. 65, 1884.
} 
torical side of the question of the acidity of succulents and its significance from all points of view. As a result of his own experimental work he decided that the acid formation and its periodicity was peculiarly characteristic of plants which, by reason of their protection against high transpiration-rate, are not favorably placed as to gas-interchange relations. He concluded that the breaking up of the acid affords an important saving of carbon dioxide, since this takes place in the daytime when the liberated carbon dioxide will be reabsorbed in the photosynthetic processes. This is essentially the point of view taken in Pfeffer's ${ }^{a}$ digest of the matter, and is the opinion that holds generally. The acid collects at night as a result of respiratory processes, and this acid when it degenerates during the daytime affords a source of carbon dioxide which is utilized in photosynthesis.

Aubert $^{b}$ has published several important papers. He thought that in the eacti it is malic acid proper that is produced, but that in the Crassulacer the substance is somewhat different and is to be regarded as isomalic acid. He corroborated the general facts already known and accepted, and he extended knowledge of the questions involved by a careful investigation of the $\frac{\mathrm{CO}_{2}}{\mathrm{O}_{2}}$ quotient. The normal gas-ratio in succulents may be regarded as less than unity. The more succulent a plant is, the more acid it contains, and hence it will absorb in the dark an increasing amount of oxygen with a minimum output of carbon dioxide, as a consequence of which its gas-interchange ratio falls. The amount of earbon dioxide given off inereases with rising temperature, or with long-continued darkness, as well as with diminishing succulence, hence under these conditions the ratio rises. He argued that succulents produce malic acid at the cost of liberation of carbon dioxide, and when with higher temperature or other causes the formation of malic acid is inhibited more of this gas is given off in proportion to the oxygen absorbed, so that the amounts of the two become more nearly equal. Not only do the succulent plants present an unfavorable epidermal and stomatal provision for gas interchange, but the succulence itself inhibits free passage of gases into and out from the tissues and hence the peculiar phenomena of their gas-ratio is correlated with their anatomical structure, which in turn is a result of their habitat.

A very comprehensive examination of the whole question of plant acidity has been made by Purjewicz, ${ }^{c}$ covering the problems of the formation and destruction of organic acids in the higher plants in general. His results as to the sources of decrease in acidity confirm those of de Vries and other workers, namely, that the causes are light, continued darkness, and high temperatures. He regarded the breaking down of the acids as an oxidation process and pointed out that in the absence of oxygen this process is greatly inhibited. He adopted the already accepted conclusion that the carbon dioxide formed by the degeneration of the malic acid in light furnishes material for photosynthesis, and that its relation to the latter process is only indirect. That there is any increase in the carbohydrates accompanying the decrease in

\footnotetext{
aPfeffer, Wm. Physiology of plants (trans. by Ewart), vol. 1, p. 326, 1904.

Aubert, E. Sur la repartition des acides organiques ches les plantes grasses, Rev. Gen. Bot., vol. 2, p. 309, 1890. Recherches physiologiques sur les plantes grasses, Ann., Sci. Nat. Bot., Series 7, vol. 16, p. 1, 1892; also as a dissertation in 1892.

An elaborate abstract in Botanisches Centralblatt, vol. 58, pp. 368-374, Kiew, 1893 (Russian).
} 
acidity he regarded as a priori improbable. Indeed, some of his experiments showed an actual deerease of these substances in the tissues with diminishing acidity. He, like Aubert and Astruc, whose papers will be discussed later, agreed with Kraus in considering carbohydrates as the ultimate material from which the acids are formed, and he did not entertain de Vries's idea of a light stimulus which is inhibitory to acid formation, which consequently results in the diminished acidity characteristic of the day period. He also maintained that a certain amount of oxygen is necessary for the formation of the acids, but the quantity is much less than that required to break them down, oxygen being, nevertheless, of greater significance in the former process than in the latter. As to the $\frac{\mathrm{CO}_{2}}{\mathrm{O}_{2}}$ quotient, he found it lowest at the periods of maximum acid formation and highest when it is being broken down. In general, he considered the evidence to be all in the direction of supporting the usually accepted conclusion that the organic acids in plants are products of incomplete oxidation. The formation of the carbon dioxide is probably not direct, but by gradual steps in which simpler and simpler compounds are produced as the gas is given off. His conception of respiration, indeed, is that it is just such a process of gradual disintegration, first of carbohydrates and then of the acids formed from them.

Astrue $^{a}$ also has contributed a lengthy paper covering the general field of acidity in plants. Considerable attention is given, however, to the question of the acidity of the Crassulacex in particular. The two forms chiefly employed for experimental purposes were Sempervivum and Echeveria. Unlike Aubert, who found less acid in the young parts and most in the recently mature tissue, Astrue reports that the acids are formed most of all in young organs which show high cellular activity and a maximum of turgescence. According to him the acids which are produced gradually tend to diminish in amount as the tissues advance in age, either by entering into combination with alkaline bases absorbed with the soil-water or by esterification, in consequence of which the cell contents lose their acid properties. His conclusions are not so different from those of Aubert as would appear at first sight, for the latter admits that the average acidity finally diminishes after the period of early maturity is passed. Probably the two writers did not have precisely the same criteria for judging the relative age of the parts used. Astruc considers that the formation of the acids is indirectly dependent in part upon previous photosynthetic activity, so that succulent plants form much less acid at night, when they have been exposed during the previous day in an atmosphere devoid of carbon dioxide. In this respect he differed from de Vries, but agreed with Aubert in thinking that the formation of acid at night is dependent upon assimilation in the day. These conclusions are obvious if, as is generally accepted, it is from the partial breaking up of carbohydrates that the acid arises. Corroborative of this position he found that etiolated tissue was much lower in acidity than that which came from normally illuminated plants. The relation of acidification to the $\frac{\mathrm{CO}_{2}}{\mathrm{O}_{2}}$ ratio was shown by the lowering of the latter at night-time, when acid formation is taking place. Astruc agreed with Purjewicz and Aubert in finding that any cause which tends to hasten the

\footnotetext{
"Astruc, A. Recherches sur l'acidité végétale. Ann. d. Sci. Nat. Botanique, Series VII, vol.
17, pp. 1-64, 1903.
} 
acidification of the plant tends also to increase the carbon dioxide output and to raise the ratio. Oxygen is necessary for the production of acid, and so necessary that in atmospheres with less than the normal oxygen-supply this process is greatly impeded. Acidification is favored when the oxygen-supply is increased above normal, and hence his general statement that acid is best produced in an atmosphere rich in oxygen. On the other hand, a supply of oxygen is necessary for the deacidification. It has been shown by other investigators, without question, that oxygen is needed for both processes; but whether Astruc's interpretation is wholly applicable to the conditions found in succulents is perhaps doubtful. There is much more detail in this contribution of Astrue which might be given, but it is not necessary to do so here. On the whole it is a corroboration of the results of Aubert.

Very recently Spoehr has published a paper which gives the first definite account of the steps in the deacidification processes, following exposure of malic acid to light. The photolytic action of light on malic acid results in the formation of a number of degeneration products, as follows: formaldehyde, acetaldehyde, formic acid, acetic acid, glycolic acid, oxalic acid, and carbon dioxide. Step by step the malic acid breaks down to simpler derivatives accompanied by a constant evolution of carbon dioxide. That the disruption of the acid should be rapid at first, becoming gradually slower, is to be expected from the greater stability of the simpler acids, especially formic acid. The oxalic acid is apparently formed from the acetaldehyde, which is one of the early products of the deacidification processes. Some of this oxalic acid is removed from the sphere of photolytic action by reason of its precipitation as a calcium salt, but the rest suffers a further splitting, since oxalic acid is highly sensitive to light. A great deal of this work was done in vitro from ordinary chemical preparations, but there are some interesting observations on the plant-juices themselves. Among the most important is the account of an attempt to determine whether deacidification is brought about through the action of an enzyme. Very careful experiments gave a wholly negative result, and it appears, therefore, that this process can not be due to any enzymatic catalyst. Indeed, it is not wholly dependent upon the living protoplasm, since the expressed juice when placed in the sunlight diminishes in acidity with the formation of carbon dioxide. The product, after exposure to light, evinces an increased power to reduce Fehling's solution; but, as the author points out, this should not be necessarily interpreted as indicating the formation of reducing sugars. Many of the substances formed by photolysis would account for this response to the Fehling test. Attention is also called to the interesting theory of Borowikow on the influence of acid media upon the hydratation of colloids and the consequent effect on growth. The possible connection of this hydratation with the acidity question is suggested, to which fuller reference will be made in the appropriate place. In this connection, it is interesting to note that Aubert stated that less water is transpired by organs richest in malic acid, a circumstance which appears in keeping with Borowikow's suggestions. However this may be, even if the acidification of the colloids did not result in conditions which greatly affect growth, at least this increased hydratative power might be a very important factor in maintaining a sufficient water-balance to keep the cells alive and active. 
In the work of Maquenne and Demoussy, ${ }^{a}$ which is very recent, we have one of the most elaborate and exact investigations that has ever been attempted in this field. New methods and new corrections in the evaluation of their experiments are introduced. The bulk of the work does not touch immediately on the subject in hand, but some passages are of interest in connection with succulent plants. In general, the authors did not concern themselves, experimentally at least, with the matter of acidity. They state, however, that the $\frac{\mathrm{CO}_{2}}{\mathrm{O}_{2}}$ ratio in young tissues is greater than in mature ones. The lower ratio found at night, when the acidity is rising, they ascribe largely to the increased solubility of carbon dioxide in the juices of the plant at the lower temperatures which prevail at night. This would cause the apparent fall in the ratio by cutting down the amount of carbon dioxide evolved from the plant. It seems, however, dubious whether this increased solubility could possibly account for enough of this gas to produce the considerable effect on the gas-ratio that is to be observed.

Among the references to the importance of the acidity of the Crassulacer and other succulents in connection with the general problem of respiration that are to be found in the more general works, we have the discussion given by Nathanson ${ }^{b}$, in his recent book on the nutrition of plants. He states his opinion very emphatically that the formation of large amounts of acid is due not merely to the diminished oxygen attendant on the morphological structure of succulents, but to a regulatory process connected with the photosynthetic activities in this type of plant. His interpretation does not really seem to be very different from that of Warburg, except that is is somewhat more vague; and as a result of his discussion it is perhaps no easier to distinguish cause and effect than in the usual statements concerning the relation of respiration and photosynthesis in succulents.

The present status of the question is about that which is expressed by Pfeffer, which is based largely on the work of Kraus and Warburg, supported in the main by Aubert and Purjewicz. The acids which are formed are the result of oxidation of sugars, which is incomplete because of the comparatively restricted supply of oxygen consequent on the morphological structure of the succulent type of plant. The disappearance of the acid, as is plainly shown by Spoehr's work, is due mainly to light, which has a photolytic action on the malic acid and breaks it up into simpler substances. The acids do not appear to stand in direct relation with the synthesis of the carbohydrates in the photosynthetic processes, but the product of their disruption, which in its final form is carbon dioxide, may be of importance in this regard. Even if Bayer's hypothesis as to the nature of the photosynthetic process were on a firmer foundation than it is, the presence of formaldehyde as one of the degeneration products of the acids, as established by Spoehr's experiments, would weaken it greatly. However, even if formaldehyde is not the primary substance produced in photosynthesis, the possibility of this substance being worked up by the plant into sugars is not precluded. Under such circumstances, it might be suggested that any formaldehyde which is formed in the process of the

\footnotetext{
aMaquenne, L., et E. Demoussy. Nouvelles recherches sur les échanges gazeaux des plantes vertes avec l'atmosphere. Paris, 1913. See also Compt. Rend., vol. 156, p. 28, 1913; ibid., vol. 156 , p. 506, 1913; ibid, vol. 156, p. $278,1913$.

Nathanson, A. Der Stoffswechsel der Pflanzen, pp. 376-394, 1910. Leipzig.
} 
degeneration of the acids might be utilized at once by the plant for constructive purposes and would not necessarily be further broken down to its final constituents of carbon dioxide and water. This, however, would not mean that the deacidification of the tissues could be effected without the evolution of carbon dioxide, for this gas is also formed in the splitting-off of some of the higher acids.

How far these present studies may help to throw much more light upon these vexed questions is perhaps doubtful. An attempt has been made, however, to accumulate a larger body of reliable data than previously existed, with the hope of being able more closely to analyze the various happenings connected with the appearance and disappearance of the acids among cacti. This has been done especially in relation to the interchange of gases which takes place during the processes that have been commonly included under the general head of respiration.

The work was largely carried on at the Desert Botanical Iaboratory at Tueson, Arizona, under the auspices and with the support of the Carnegie Institution of Washington. To be able to work upon these desert plants in their native habitat and with the facilities afforded by the laboratory was, as the writer acknowledges with great pleasure, an unusual opportunity. It is a further pleasure to acknowledge the interest of the director, Dr. D. T. MacDougal, whose suggestions have been helpful, and also of the other members of the staff, particularly Dr. H. A. Spoehr. The gathering of so much experimental data in connection with the gas-interchange problem would have been almost impossible without the assistance of Miss M. E. Latham, who collaborated in the work on gas-interchange. 


\section{EXPERIMENTAL METHODS.}

The methods employed in this investigation present nothing markedly new. There were, in general, three lines along which the work was carried out. In the first place, there was the determination of the acidity of the tissue both as regards the pure juice and as regards the total amount of acid present. Secondly, determinations of carbon dioxide evolution were made by the wellknown Pfeffer-Pettenkofer method, to fix not only the diurnal periodicity in relation to the normal temperature changes, but also to determine the effect of various external agencies upon the rate. The last and most important line of investigation was that of the gas interchange in darkness between the plant and the atmosphere. For this the methods familiar from the work of Bonnier and Magnin and many others of their school were used, and their micro-gas-analysis apparatus was employed in determining the amount of carbon dioxide evolved and the amount of oxygen absorbed, and then the same or parallel material was investigated to determine its acidity. This involved the making of a very considerable number of gas-interchange experiments simultaneously with the acidity measurements.

\section{DETERMINATION OF ACIDITY.}

At first attention was devoted wholly to the determination of acidity in order to become familiar with the behavior of the plants in this regard, under varying conditions. The acidity may be measured by the expressed juice, and while the writer is very well aware that this juice does not necessarily represent the sap of the cell contents, as it must include also any fluids which are present in the intercellular spaces, it at least gives the amount of free acid present in the tissues, and is the only index of a quantitative sort that we have for such a study. In general, the acid material expressed from the tissue was immediately titrated without further purification or decolorization. In many of the cacti the juice darkens very rapidly on exposure to the air, due perhaps to the formation of oxidases, but Opuntia versicolor presents less difficulty than most in this regard. Only rarely did any marked discoloration of the expressed liquids occur, even after they had stood in contact with the air for as much as two hours. Nevertheless, even when no change of color ensues, there is always danger that oxidation processes may set in and affect the acidity unless titration is made at once. Various methods of extraction and purification were tried, and the method to be described below was adopted, since, in view of the scope of the work which the writer had in mind it was essential to reduce the processes for the determination of acidity to the simplest means consistent with reliable results.

For experimental purposes Opuntia versicolor presents a great advantage over most of the cacti in that the amount of mucilaginous substance, which is squeezed out in the process of pressing the tissue, is minimal. Indeed, there is commonly none whatever except from the very dry, flaccid joints. This is true also of some other species that were tried, such as Mamillaria grahami, Carnegiea gigantea, and Echinocactus wislizeni, but there is not such a wealth of material of these forms within easy reach-not, at least, as far as concerns the numbers of individuals. As for the bulk of tissue one giant cactus would, indeed, afford enough for a whole investigation, but for obvious reasons it would hardly be profitable to carry on a research with a single specimen which would necessarily soon become affected with serious traumatic reactions. 
The usual method of acid extraction was this: A sufficiently large sample, say of about 50 grams of tissue of healthy joints, was pressed in an ordinary large-sized meat-press. From such a sample there were obtained usually at least 10 e.c. of what is termed in the succeeding pages "pure juice." The writer expressly avoids the term "cell-sap," which means little or nothing and is apt to give a very erroneous impression. From young and very turgid tissue the amount of juice so obtained was sometimes as much as 20 or even 25 c.c., and from old flaceid tissue as low as 5 c.c. With the latter material, indeed, it was sometimes necessary to use a considerably larger sample in order to obtain enough juice to give a satisfactory result, for in all but a very few cases the titrations of pure juice represent at least 10 c.c. This juice as it came from the plant was of course discolored with chlorophyll and finely comminuted tissue and was strained or filtered before titration. When diluted with several times its bulk of water it made a very acceptable solution for titration purposes, and its slightly greenish color, as soon as the eye became accustomed to discounting its presence, did not interfere seriously with a satisfactorily sharp reading of the end point.

This sample of the tissue, already once pressed, was wetted and pressed again and this process repeated a second and third time. Trial showed that the amount of acid obtained from a fourth pressing was negligible. The tissue that remained was washed into a flask and shaken vigorously with water. All extracts obtained by the second and subsequent pressings and the water in which the squeezed tissue had been shaken were mixed together and strained and used later in determining what has here been called "total acidity.

In the actual titration as much of the pure juice was taken as could be accurately measured, and in almost all cases it was seen that this should be at least 10 e.c. Phenolphthalein was then added and the alkali run in from the burette until the end-point was satisfactorily determined. In doubtful cases it was sometimes purposely over-run and titrated back with standard acid. The solution most generally employed for titration was an $\mathrm{N} / 10 \mathrm{KOH}$, though in some instances, where little acid was expected, an N/20 solution was employed. As given in the tables, all results have been reduced to the decinormal equivalent. The acid used for titrating back was an appropriate strength of $\mathrm{HCl}$.

Any remaining juice and the washings of all the apparatus which had contained it were added to the secondary extractions, already spoken of, and the whole made up to some definite quantity, usually 250 c.c. An aliquot portion of this was titrated, as with the pure juice, at least two titrations being made in every case. All of these processes can be carried on with considerable speed, and while it is possible that this simple method for determining the acidity may not be susceptible of as great accuracy as a more elaborate one, it has two distinct advantages: It is possible to make many more observations in a given time, and the juices are titrated in a practically unaltered condition. No question of changes that might have taken place in the processes of extraction can come in. It is, indeed, true that not every plant, certainly very few of the cacti, yield their acid so easily and in a form so little contaminated as does Opuntia versicolor, and, as has previously been stated, it was for this reason that this species was so largely employed. The only trouble that arose was the occasional presence of the mucilaginous substances which are so characteristic of the cacti, but these rarely occurred in considerable quantity. When 
they were present, care had to be taken not to make false reading of the endpoint because of the uneven coloration which ensued, owing to the lack of homogeneity of the extract. It was found that by constant agitation the mucilaginous substance could be made to color evenly with the more fluid portions of the sample.

The actual total acidity, of course, will be the multiple of the aliquot portion titrated, plus whatever acid has been estimated as pure juice. In the earlier experiments the acidity of the pure juice was not determined, as water was used in connection with the first pressing, but this method was soon abandoned. The acidity of the pure juice is the quickest means of obtaining the relative acidity of a number of specimens, and, as it varies elosely in accordance with the total acidity, it will serve at times for the necessary index of the condition of the tissue. In some of the later work, where speed was a necessary factor, the total acidity was not determined. In all of the tables in which acidity is recorded it is indicated which of these three ways was used, $i$. e., total acidity alone, acidity of juice alone, or the two together. It will be noted that the total acidity in most cases has been calculated both as to amount per gram fresh weight and per gram dry weight. The importance of the latter becomes evident when we wish to compare the acidities of flaceid specimens with those of turgid specimens. The former showing, as they do, so much higher percentages of dry weight, the acidity per gram solid substance becomes even less than it appears when reckoned according to fresh weight.

In all cases the tables show the acidity in terms of cubic centimeters of $\mathrm{N} / 10 \mathrm{KOH}$, either per cubic centimeter of the pure juice of per gram fresh or dry weight of the material used. For the sake of brevity it is commonly stated that the acidity was such and such a figure per cubic centimeter or per gram, meaning by this that that was its value in terms of cubic centimeters of the decinormal alkali solution.

Occasional exceptions to the praxis as outlined were made where demanded. In a few cases, where only very small samples of the cactus joints were of necessity available for acidity determination, it was not possible to obtain as much as 10 c.c. of the pure juice, so a smaller amount had to suffice. The use of a smaller quantity is of course less satisfactory and was not resorted to when it was avoidable, but, inasmuch as the results obtained were not discordant with those from larger samples, it is fair to assume that they were sufficiently trustworthy. Another departure from the usual practice was the occasional determination of the acidity in the whole of the residual pressings without making the liquid up to a known volume from which an aliquot part could serve. While this method is not necessarily inaccurate, it is attended with a certain risk of losing the whole titration. It may be said that this was only done when, as in the other case, there was only a small quantity to work with.

In the work done in 1912 and subsequently, all of the solid matter from the samples of tissue used was recovered as carefully as possible and was dried, to be used later in determining the dry weight. At the time of making the acidity determinations, it was found convenient merely to dry the material in the sun - a process which takes place very rapidly in Tucson - and to leave the final drying to be done at convenience in the winter. In weighing the samples of the fresh material it was not usually the practice to carry them down closer than $0.1 \mathrm{gram}$, but with the dried specimens the weight is given to $0.05 \mathrm{gram}$. 
Individual differences in the living shoot, due to a variation in the number of spines and so forth, would amount to a variation larger than the limits thus set. Since we have no idea what their function may be, it seemed unwise to remove the spines, lest a wound stimulus might result; and to obtain, in any case, a strictly quantitative estimate of the amount of tissue actually active in a cactus joint would not be an easy matter. As a rule, it is better not to mutilate tissues used in experimentation more than is absolutely necessary. It will be seen in the later discussion that the possible traumatic reaction, resultant upon the necessary removal of the joints from the plant, was carefully tested out.

In most of the work Merck's reagent $\mathrm{KOH}$ was employed and as an indicator phenolphthalein was found satisfactory. It takes a little practice to satisfy oneself as to the end-point of the titration, but once familiarity is attained it is entirely possible to get results that are consistent among themselves and which also must closely approximate the absolute quantity of acid present.

Reference has already been made to the mucilaginous substances so frequently found as a result of crushing and pressing tissues of cacti and to the extraordinary freedom of Opuntia versicolor from this disadvantage. The other common cylindrical opuntias (O. mammilata, $O$. fulgida, O. spinosior, and especially $O$. leptocaulis) all gave copious amounts of this mucilaginous material which, showing as it does an acid reaction because of the presumably watery solutions held in it, must be included in the titration. As the alkali penetrates the collodial mass relatively slowly, and as it is not possible to ascertain what reactions may take place between it and the potassic hydroxide, it is obvious that only an approximate determination of the acidity can be made by the method employed. It is not impossible that one might devise a method to obviate these difficulties, but that was not attempted in this work, since the $O$. versicolor afforded a sufficient field for study. It should be added that the two flat opuntias common around the laboratory at Tucson, namely, $O$. discata and $O$. blakeana, are very mucilaginous.

\section{DETERMINATION OF RESPIRATION BY THE PETTENKOFER METHOD.}

For the ready and accurate determination of the evolution of carbon dioxide, there is no apparatus more satisfactory than the Pfeffer-Pettenkofer or some of its modifications. The type employed here was that described by Pfeffer $^{a}$ in his paper on intramolecular respiration, with certain modernization in details. The apparatus is so well known that description of it would be superfluous. All of the precautions which are necessary for accurate results were rigidly adhered to. The air passing through the apparatus was carefully washed and the regulation of its flow carefully guarded. In the experiments carried on in New York, the suction used was that produced by an aspirator attached to the faucet, where throughout the building there was maintained by an automatic pump a constant pressure of 60 pounds. In Tucson the exhaustion apparatus consisted of a small electric pump, the suction of which was equalized by a water-column. In both cases an additional safeguard was interpolated between the suction source and the Pettenkofer apparatus by means of a simple mercury safety-valve that has been used by numerous exper-

aPfeffer, W. Ueber intramolekulare Athmung. Untersuchungen aus Tübingen, vol, 1, p. 636, 1881-85. 
imenters. This valve was set so as to make the flow constant at the least suction possible that would guarantee a steady stream of air through the absorption tube. It is perhaps not necessary to say that, even with all these precautions, the apparatus was constantly watched and in only a few instances was there any trouble with the air-current. To obtain satisfactory results with any suction apparatus of this sort it is essential that the flow of air or gas should be as even as possible. For most of the work the flow was measured by a gas-meter of the American Meter Company, which could be read to 0.005 cubic foot, and a rate of 5 liters per hour was used. In Tucson, in the absence of the meter, the gas-volume was measured by displacement of water. A by-pass was arranged in the suction apparatus so that without disturbing the adjustment of the mercury valve a much faster stream could be allowed to pass through the Pettenkofer apparatus when it was desired quickly to change the atmosphere in the receiver. It should be added, however, that the pressure was never allowed to become diminished by more than a few millimeters of mercury, lest the relation of the internal gases in the tissues be disturbed.

The amount of rubber tubing with which the gases from the plant came in contact was cut down to a minimum, and where its use was necessary the inside of the tube was vaselined so as to prevent, as far as possible, any diffusion of the carbon dioxide. These rubber connectors were frequently renewed, so that any deleterious effect that the vaseline might have on the rubber need not be considered.

Constancy of temperature was insured by immersing the receiver holding the plants in a large container filled with water. Lacking automatic control, this was kept at the desired temperature by constant watching. For raising the temperature one of the familiar types of immersed electric heaters was used and for lowering it cold water or, if necessary, ice. A paddle stirrer was kept in agitation from time to time to insure even distribution of heat. Where pure hydrogen or nitrogen was used great care was taken to wash the gas and to eliminate all traces of oxygen. A by-pass in the supply tubes made it possible to sample the gas passing through the apparatus without disturbing its flow for a measurable length of time. When hydrogen was used it was manufactured in the usual way and purified twice before being run into the apparatus. For the most part, however, nitrogen was preferred where an atmosphere without oxygen was desired. The commercial product is delivered in high-pressure cylinders and contains only a small percentage of oxygen and no poisonous gases, as far as the writer is aware. Besides being led through the usual tubes containing potassium permanganates, potassic hydroxide, etc., this was washed of its oxygen by being passed through two extra long Emmerling towers and a whole battery of Pettenkofer tubes filled with alkaline pyrogallol. Repeated tests showed that no trace of oxygen was left after this treatment.

As an absorbent for the carbon dioxide, the writer preferred the usual barium hydroxide, except in the few instances where the apparatus was left to run a long time without change, when the heavy precipitate would clog the even flow of the air-current. In such cases a solution of potassic hydroxide was used. The amount of carbon dioxide given off was determined as usual by the decrease in alkalinity of the barium-hydroxide solution in the Pettenkofer tube. In conclusion it may be said that toluene vapor was introduced into the gas flowing through the apparatus, to obviate the difficulties arising from the respiratory activity of possible bacterial forms. 


\section{METHODS IN GAS-INTERCHANGE DETERMINATIONS.}

The preliminary experiments were made by the writer in the spring of 1912 , at which time, also, the scope of this phase of the investigation was planned. During the summer at Tucson charge of these experiments was given to Miss M. E. Latham, who later analyzed the samples and compared the results with analyses carried out by the writer. The series of experiments undertaken in the summer of 1913 were performed by the writer during a brief stay at Tueson and were analyzed by the collaborators during the following winter. With the new apparatus employed during the second summer it was possible to carry through a large number of experiments in a short time and it was found possible to keep the gas samples for an indefinite length of time in tightly stoppered, mercury-sealed vials. In practice the tubes were about half or two-thirds filled with the gas over a mercury bath. Stoppers were then jammed in very tightly and the tubes kept in an upright position. The only problem was the safe transportation and this was solved by personally carrying the samples so as to insure the integrity of the mercury seal. Two lots were thus brought across the continent, and the writer is absolutely sure that nothing happened in either journey to disturb the seals and thus invalidate the samples. Analyses made both before and after the journey showed no difference; indeed, analyses made in 1914 from samples collected in 1912 gave the same results as those made in 1912. This method of procedure proved itself highly advantageous in many ways. In the first place, it allowed of the collection of a large number of samples during rather brief visits to Tucson, and secondly, the analyses of the samples could be made at leisure under more favorable conditions than possible at the high temperatures found in Arizona during the summer. The making of micro-analyses is exacting work and requires a care in manipulation that is not likely to be attained if the work is done under pressure of time. There is, indeed, the admitted disadvantage that some of the results may be found unsatisfactory after it is too late to repeat the experiments, but considering all circumstances this was by far the best course to adopt.

The manner first employed for obtaining the required gas samples was somewhat primitive, although efficient. The material under investigation was placed in wide-mouthed flasks (Grignard flasks) of from 600 to 800 c.c. capacity, and the flasks were then rigidly fixed over dishes of mercury to seal them. After a desired lapse of time samples of the atmosphere within the flasks were obtained by means of a bent pipette filled with mercury and operated with a rubber bulb. In order to insure a mixing of the gases before sampling, the mercury in the pipette was several times violently ejected into the flask while it was still sealed. It is of course unnecessary to say that the pipette was so constructed that it was not possible to eject all the mercury on one compression of the bulb and thus contaminate the sample with the air which the latter contained. The gas thus drawn off was transferred to the tube in which it was to be stored without removing the pipette from the mercury bath. The vials into which the samples were run had been filled with mercury with such great care that no bubbles of air adhered to the sides of the vial. No matter how clean the glass may be, and even if the mercury itself is ordinarily pure, bubbles of some size frequently stick closely to the walls. In the filling of these tubes, then, each was minutely inspected, and the greatest care was taken to avoid this possible cause of serious contamination of the gas sample. When the vial full of mercury was in a satisfactory 
condition it was a simple matter to expel the gas in the pipette into the vial until the latter was from half to two-thirds full of the sample. If the analysis was not to be made at once a stopper was very tightly jammed into the mouth of the vial and it was then placed in a case where it could not possibly fall on its side. The gas, under some compression, had a seal of 8 to $10 \mathrm{~mm}$. of mercury below it, so that it could stand considerable rough handling without bringing the gas in contact with the stopper itself. These samples that were brought back to New York were kept carefully in an upright position during transit.

After the samples had been removed the eapacity of the flask with the cactus joints still in it was determined by direct measurement and the material itself used for an acidity determination and later for the estimation of dry weight.

In the summer of 1913 an extended series of experiments was made under various conditions. In these the samples were obtained and capacity of the flasks were determined by an improved method. The apparatus used for this was modeled after that devised by Aubert ${ }^{a}$ with a few modifications. Follow-

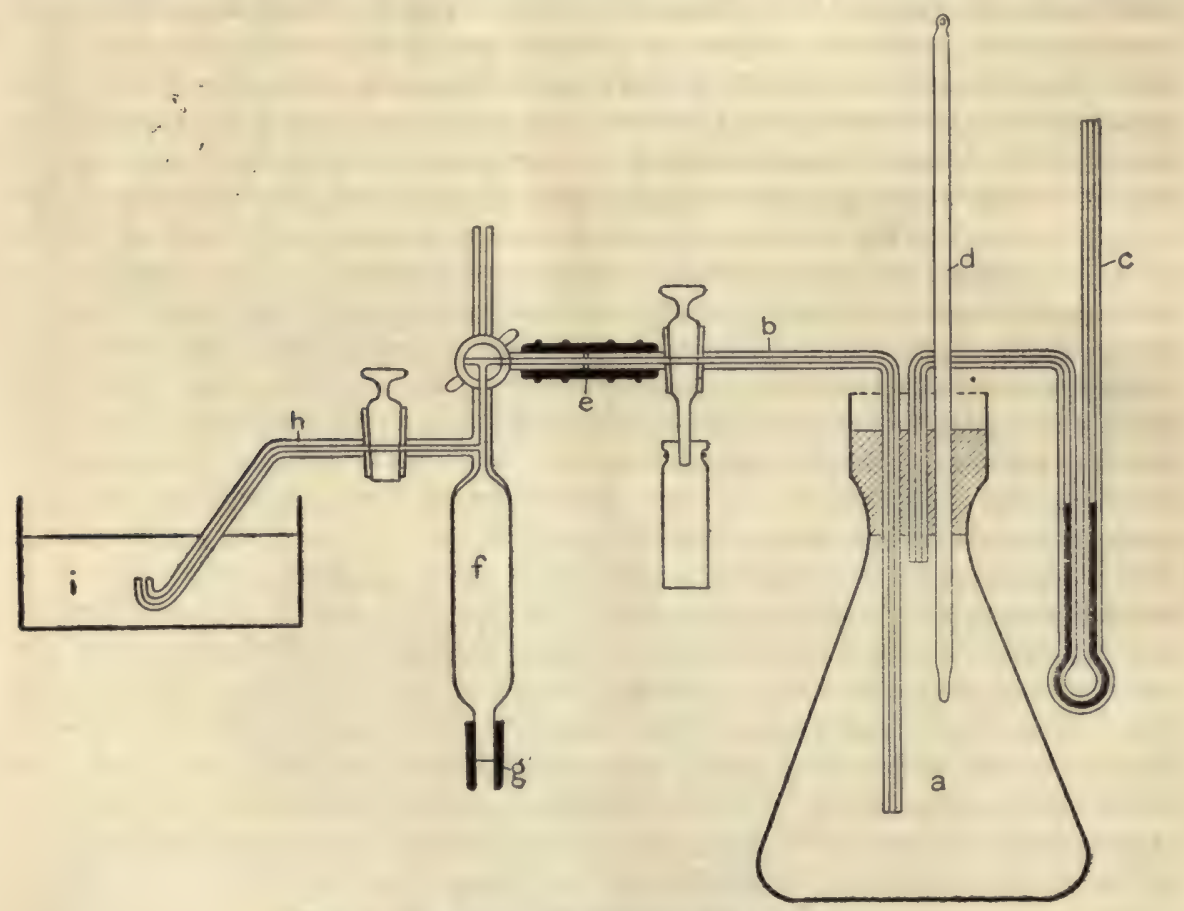

Fre. 1.-Apparatus for obtaining gas samples.

$a=$ receiver; about 750 c.c. capacity.

$\boldsymbol{b}=$ delivery tube.

$c=$ manometer

$d=$ thermometer.

$6=$ rubber connector; wired. $f=$ bulb of sampling apparatus: 25 c.c. capacity.

$g=$ rubber tube connecting with mercury reservoir.

$h=$ delivery tube of sampling apparatus.

$i=$ mercury bath.

The attachment for determining capacity of receiver was simply a large bulb of about 75 c.c. capacity, attached to the delivery tube $b$ in the same way as shown above.

aubert, E. Recherches physiologiques sur les plantes grasses. 2d part, p. 11, 1892. See also Abderhalden, Handbuch d. Biochem. Arbeitsmethoden, vol. 3, p. 501. 
ing the idea adopted by Pallidin and Kostytschew the receiving flasks for the plant material were provided with extensions of the necks in the form of collars about $25 \mathrm{~mm}$. high, so that when the stopper was inserted the flasks could be securely sealed by pouring on enough mercury to cover it $(a$, fig. 1$)$. The stopper was punctured with three holes. In one a thermometer ( $d$, fig. 1) was thrust, in another a $U$ manometer (c, fig. 1$)$, and in the third the delivery tube ( $b$, fig. 1 ), which ran well down into the flask and was closed on the outside with a glass stop-cock. Figure 1 shows the general appearance of the receiver. These flasks proved exceedingly convenient, as they could be carried easily from place to place without disturbing the seal, could be darkened by covering with tinfoil and paper, and could be immersed in water if occasion required, without any danger that the material inside would become wet. They could also be set up with such rapidity that it was possible to have four sets of experiments running simultaneously without taxing the manipulator.

The material was placed in these receivers, and, after being left the desired length of time, samples were drawn off and the capacity was determined in the manner to be described. When the sample was to be taken the outlet tube was connected with what may be called the sampling apparatus, which was designed after the form used by Aubert, but differing in that it was detachable and so could be used for an indefinite number of receivers. There is not only this advantage, but also that which comes from having the receiving flasks readily transportable. This sampling apparatus consisted of a bulb of about 25 c.c. ( $f$, fig. 1 ), capacity provided with three openings. The upper one, a bent narrow-bore tube, was connected, when desired, with the outlet tube of the receiving flask, by means of rubber tubing, properly wired, and each time the connection was made it was also wired $(e, f i g .1)$. The two tubes had ground ends and came in very close contact when brought together. This seal was repeatedly tested by exhaustion and could hold a mercury column of 50 or $60 \mathrm{~mm}$. indefinitely. It may be mentioned that the ordinary cottoncovered annunciator wire was found to be excellent for such wiring purposes, as it had no tendency to cut the rubber tube when tightened around it. The second outlet, which was really a branch of the first, led to the small-bored delivery tube $(h$, fig. 1$)$, so bent as to deliver the gas conveniently when the free end was immersed in the mercury trough $(i$, fig. 1$)$. This delivery tube was provided with a glass stop-cock. There was also an extension upwards of the first outlet with a three-way cock attached, but this could have been dispensed with as well as not. The third opening at the bottom of the bulb led by means of a long rubber tube ( $g$, fig. 1$)$ to a mercury reservoir which could be elevated or depressed, as required to fill or empty the bulb.

To withdraw any gas the whole system up to the stop-cock in the outlet tube of the receiver was filled with mercury, great care being taken to see that no air was eaught in the bulb, tubes, or stop-cocks. Inasmuch as the stopcock on the receiver had a vent looking downwards, it was possible to run any quantity of mercury through the apparatus. In a similar fashion the delivery tube of the sampling contrivance was filled with mercury. Before proceeding, the whole apparatus was once more inspected for air-bubbles, especially those which are apt to stick in the bore of the stop-cocks, and to see that the joint with the receiver was tight. The stop-cock on the receiver was now opened simultaneously with the depression of the mercury reservoir so that some gas 
was drawn into the bulb from the flask. By raising and lowering the mercury reservoir this was rapidly repeated several times, to stir up the air in the flask. This mixing of the gas was commonly aided by shaking the flask gently before attaching it to the sampler, and, when considered complete, some gas was drawn into the bulb and the stop-cock on the receiver was closed. The mercury reservoir was then raised and the stop-cock of the delivery tube opened, a vial carefully filled with mercury being held to receive it. The amount of the gas sample taken was usually about 2 c.c. The vial was stoppered and stored away as previously described.

It is well to mention here a precaution that was observed in every case, namely, that in withdrawing the sample only a very slight depression in pressure, not more than 4 or $5 \mathrm{~mm}$., was allowed at any time, so that the error that might arise from internal gases withdrawn from the tissues could be neglected. This is especially important in dealing with massive tissues like those of the cactus joints, which must, without question, hold gases, especially carbon dioxide, dissolved in their juices or held in the intercellular spaces. It is not clear to the writer whether this precaution has always been observed by other experimenters, but it is certainly an important one. It is needless to add that the mercury used was clean and dry as possible, as these samples were to be kept for some time before analysis. The steps herein described are not as complicated as they sound and in a very short time the operator can learn to carry through the whole procedure in not more than 5 minutes. As a matter of practice the writer often set up series of four experiments at 5-minute intervals and when the time for sampling came there was no undue hurry.

For the purpose of determining the capacity of the receiver with its charge of specimens, another much larger bulb, of the capacity of about 75 c.c., was used. This was tightly wired to the outlet tube as before. The stop-cock on the outlet tube was turned to allow mercury to flow out of the nipple and the whole bulb and adjoining tube were filled with mercury, after which the stopcock was turned to connect with the receiver. Then the mercury was drawn off to a definite mark in the lower stem, to which the volume had been accurately calibrated. Simultaneous reading of the depression of the manometer and of the barometer was taken, giving the necessary data for determining the capacity of the flask. Before making the calculations there were added to the calibrated value of the bulb the capacity of the short end of the small-bored outlet tube of the receiver which projected beyond the stop-cock and that of the bore of the stop-cock itself, all of which formed a part of the system of the exhaust bulb. Possibly this correction was not material, for the actual cubic capacity of these parts was very small, but after it had once been determined it was a simple matter to add this figure to the capacity of the bulb.

The general method of procedure is the one first used by Bonnier and Magnin and one that has been successfully employed by many experimenters. The gas samples were analyzed by means of the Bonnier and Magnin microgas-analysis apparatus, ${ }^{a}$ which is too well known to need description. While it is by no means a perfect apparatus, it gives very consistent results when used by a careful experimentalist. All of the samples were analyzed at least

aAubert, E. Nouvel appareil pour l'analyse des gaz. Rev., Gen. Bot., vol. 3, p. 97, 1891. Thoday, D. On the capillary eudometric apparatus of Bonnier and Magnin, etc. Annals of Botany, vol. 27, p. 565, 1913. 
twice, so that there was an adequate check on any errors. A considerable number of supplementary analyses were made by the writer and the surprisingly close agreement gave evidence that individual manipulation does not cut as large a figure in the use of the Bonnier apparatus as might be supposed, and that the accuracy of the results was something more than merely relative.

By this method the amount of carbon dioxide is obtained by the diminution in volume of the gas sample following exposure to a solution of potassium hydroxide, and the oxygen is determined by the further absorption which follows the addition of pyrogallic acid. Whatever remains of the sample is taken as nitrogen. If nitrogen has been neither absorbed nor given off from the tissues, this remainder will amount to 79.1 per cent, $i$. $e$., the quantity present in normal air. If this is the case, the calculation of the percentage composition of the gas sample may be readily made directly from the figures obtained. If on the other hand the amount of nitrogen is more or less than 79.1 per cent the following correction must be applied: ${ }^{a}$

Let the amounts of carbon dioxide, oxygen, and nitrogen found be respectively $a, b$, and $c$. Further let the product of the normal percentage of nitrogen in air into that of oxygen, i. e., $\frac{20.9}{79.1}$, be $q$. Then the actual amount of oxygen absorbed is $c q-b$, and the $\frac{\mathrm{CO}_{2}}{\mathrm{O}_{2}}$ qutotient may be expressed as $\frac{a}{c q-b}$.

The question also arose as to whether a correction might not be nacessary, for the reason that the experiments were performed and the samples gathered in Tucson, Arizona, at one temperature and pressure, while the gas-analyses were mostly made in New York at another temperature and pressure. Investigation showed, however, that the correction due to the nonconformity of carbon dioxide to the gas law would affect results less than 0.1 per cent, which is below the limit of experimental error. ${ }^{b}$ Consequently this correction was disregarded.

In comparing the results obtained by this method with those from the Pettenkofer apparatus, where the earbon

TABLE 1.

\begin{tabular}{|c|c|c|c|}
\hline \multirow{2}{*}{ Temp. } & \multicolumn{3}{|c|}{ Barometric pressure. } \\
\cline { 2 - 4 } & $690 \mathrm{~mm}$. & $700 \mathrm{~mm}$. & $760 \mathrm{~mm}$. \\
\hline${ }^{\circ} \mathrm{C}$. & $m g$. & $m g$. & $m g$. \\
22 & 1.486 & 1.508 & 1.633 \\
24 & 1.460 & 1.482 & 1.614 \\
26 & 1.434 & 1.456 & 1.585 \\
28 & 1.408 & 1.429 & 1.558 \\
30 & 1.382 & 1.402 & 1.529 \\
32 & 1.355 & 1.375 & 1.500 \\
34 & 1.328 & 1.348 & 1.472 \\
36 & 1.301 & 1.321 & 1.444 \\
\hline
\end{tabular}
dioxide is estimated by weight, it is necessary to reduce them from cubic centimeters to milligrams. As most of the experiments were carried on at Tucson the barometric pressure of that locality must be taken into account. The average fluctuation is from 690 to $700 \mathrm{~mm}$. and the calculations were made on that basis. Table 1 was compiled from figures obtained by extrapolation of known datac and is the weight in milligrams of 1 c.c. of carbon dioxide, saturated with water-vapor at the different temperatures and pressures indicated.

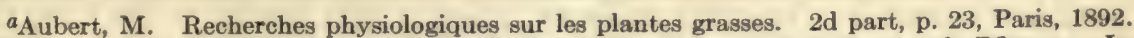
Pallidin, W., and S. Kostytschew. Methoden z. Bestimmung d. Athmung d. Pflanzen. In Abderhalden's, Handbuch der biochemischen Arbeitsmethoden, vol. III, part 1, p. 500.

'Amagat. Ann., Chim. Phys., series 4, vol. 29, p. 246, 1873. F. Fuchs. Wiedermann's Annalen, vol. 38, p. 302, 1889.

'Castell-Evans, J. Physicochemical tables, vol. 1, pp. 354-357, table Lrx, J. London, 1902. Calculated from the data of Regnault.
} 


\section{GENERAL METHODS OF PROCEDURE AND PRECAUTIONS.}

Most of the gas-interchange and respiration experiments were, of course, carried on with the plants in darkness. Whatever method was used to exclude light, care was taken that it was efficient. Owing to the peculiar behavior of the cacti in the matter of evolution of carbon dioxide, a number of experiments were, however, performed in diffuse light or direct sunlight. Those in diffuse light were exposed, uncovered, on the laboratory table or were placed out of doors in the shade. Where direct sunlight was used the receivers containing the plants were immersed in water cooled with ice. This method of preventing excessively high temperature consequent on the inclosure of the specimens in glass was efficient, though somewhat crude. Water, of course, may absorb light to a limited extent, but not as much as does glass. Care was taken to see that the water was clear and that the receivers were not immersed any deeper than necessary.

In the laboratory at Tucson, where a medium constant temperature was required, the subterranean dark-room proved very convenient. Over any 24-hour period the temperature change would rarely be more than a fraction of a degree and not to be considered from the standpoint of a physiological stimulus. For higher temperatures a fairly even rate was obtained by the use of shrouded incandescent bulbs, which, even without regulation, gave a temperature which varied only a degree or two if care was taken to prevent radiation. For short periods of exposure to high temperatures the small greenhouse attached to the laboratory gave, in clear summer weather, a temperature that was often above $40^{\circ} \mathrm{C}$., and would remain fairly constant for several hours during the middle of the day. For low temperatures ice cooling was employed, and if the body of ice were large enough surprisingly regular temperatures were obtained by it. While arrangements of this kind may not make claim to be constant in the proper sense of the term, they served for the study of the larger effects of temperature change in a physiological sense. In New York the laboratory temperature was fairly constant during the winter, varying from $29^{\circ}$ to $23^{\circ} \mathrm{C}$.; for lower temperatures an ice-box was used and for higher ones the usual type of bacteriological incubator served.

When the results of any series of determinations were to be compared among themselves, every care was taken to have samples of material as similar as possible. The acidity of different plants is not necessarily the same at the same time of day; indeed, it varies over a considerable range among plants which appear similar and are similarly placed. It was found, however, that tissue of the same age from one plant was fairly constant. Therefore joints from only one plant were used in any one series of observations. To determine the initial acidities it was, of course, impossible to use the actual material that was to be employed in the gas-interchange experiment, but in such cases joints as nearly similar as possible were chosen and have been termed "parallel" material. The writer is aware that even with these precautions errors may have crept in. It is, for instance, possible that similar joints from the same plant might occasionally be of widely different acidity, and confusion might arise by correlating their respiratory activity with the wrong acidity conditions. It may be said, however, that this would probably not happen often. Experience taught that the acidity distribution in the tissues of a healthy plant is fairly constant. A certain check on such errors was also afforded by the final acidity, which was always determined from the identical 
material from which the gas-interchange ratio was obtained. It may be added that the consistency of the results among themselves was satisfactory evidence of the sufficiency of this method.

For purposes of experiment three classes of joints were distinguished, as follows: young, mature-turgid, and mature-flaceid. Young joints were those just formed or forming, very turgid and possessed of leaves. Mature-turgid joints were those just back of the young joints or the terminal ones before the young joints were formed. They were presumably of the previous year's growth, highly turgid, and during the rainy season often showed the very characteristic longitudinal fissures, lightly healed with periderm-like tissue. Mature-flaccid joints were those of age similar to the last, but from plants that had not recently had any water-supply, that is, in the condition that obtains before the summer rains. Joints older than these were not used, partly because they commonly become too large and partly because the amount of woody tissue increases. For the sake of brevity, these two kinds of mature joints hereafter will be designated simply turgid and flaceid, it being understood that the young ones are necessarily turgid.

In choosing material for experimentation, it was necessary always to examine it for the grubs of insects that frequently burrow into the tissues. They can usually be detected with ease from the outside, but as an additional precaution the joints were inspected when they were split preparatory to juice extraction, after they had served for gas-interchange or respiration observations. Needless to say, if any contaminations of this kind were found the whole experiment was discarded, but as a matter of fact only once or twice was it necessary to do this.

TABLE 2.-Acidities of tissues of different ages.

\begin{tabular}{|c|c|c|c|c|c|c|}
\hline & \multicolumn{2}{|c|}{1 year. } & \multicolumn{2}{|c|}{2 years. } & \multicolumn{2}{|c|}{3 years. } \\
\hline & Total. & Juice. & Total. & Juice. & Total. & Juice. \\
\hline Series I . . . . . & 1.26 & 1.40 & 1.23 & 1.41 & 1.18 & 1.38 \\
\hline Series II.... & 0.94 & 0.86 & 0.91 & 0.85 & 0.87 & 0.85 \\
\hline
\end{tabular}

The young joints were generally more turgid and showed higher acidity and greater oscillation thereof than did the old ones. As has been said, the mature joints were presumably of the previous season's growth, but it is not always easy to determine the age of a joint from its external appearance. Commonly a terminal joint is but one season old, but if the plant put forth no new growth during the previous growing period the distal one may be at least two years old. Since this is the case, tests were made to determine how greatly age affects acidity. The results show that the difference in this regard is very small as between the 1 year and 2-year-old shoots, but begins to show in the third year. Even this applies only to total acidity, for the juice differs in strength very little. It is no doubt owing largely to the increase in the heavy mechanical and vascular tissue that the total acidity decreases with age, for the actual amount of succulent parenchyma must be relatively smaller in a given weight of old joints than in younger ones. The averages given in table 2, from the experiments set forth in table 22, show that no serious error could have resulted if occasionally 2 -year-old joints were used instead of those but a year in age. It is safe to say that no material older than this was used. 
The dry weights of the material show that the manner of selection resulted in a pretty constant type of tissue, as they did not vary in any class over a great range, at least not in any one season. The turgid joints averaged about 20 per cent dry substance, varying from 16 to 22 per cent in a series taken at random. The flaccid joints showed, as would be expected, a much greater percentage of dry weight, the average of all the determinations made being 29 per cent. For the young joints, which are by far the most succulent of all, the amount of dry substance is lowest, a little over 16.5 per cent. However, in discussing these general averages, which include material taken during the summers of 1912 and 1913, attention should be directed to the fact that the amount of solid material in proportion to the fresh weight was not the same both seasons as the table below shows. The winter of 1911-12 was a normal one, both as regards precipitation and temperature; and the summer rains, which began in July, while somewhat below the average, were fairly copious. Not so in the following season, when the winter temperatures were at times abnormally low and the rains of both the winter and the following summer were very light. As a result of these conditions the flaccid-mature joints in 1913 showed an increase of nearly 6 per cent in dry weight over those used during the previous year. The young joints also contained a greater proportion of dry substance, but the gain was less, being only about 3 per cent. The

TABLE 3.-Average per cent of dry weight of material in all gas-interchange experiments in 1912-1913.

\begin{tabular}{|c|c|c|c|c|c|c|c|}
\hline & \multirow{2}{*}{ 1912-13 } & \multirow{2}{*}{1912} & \multirow{2}{*}{1913} & \multicolumn{2}{|c|}{1912} & \multicolumn{2}{|c|}{1913} \\
\hline & & & & Max. & Min. & Max. & Min. \\
\hline Young...... & 16.6 & 15.3 & 18.6 & 17.1 & 13.6 & 22.3 & ${ }^{1} 17.2$ \\
\hline Mature-turgid. . & 19.5 & 19.8 & ${ }^{2} 19.2$ & 23.7 & 17.7 & 24.0 & 16.1 \\
\hline Mature-flaceid. & 29.2 & 26.2 & 31.0 & 28.5 & 25.9 & 35.7 & 25.7 \\
\hline
\end{tabular}

${ }^{1}$ Excluding the one instance mentioned above, where it was 9.7 per cent.

'These were from irrigated plants.

old turgid joints were about the same, but they do not come into consideration in this connection, as the turgidity in all cases in 1913 was attained by irrigation. In the one instance in 1913, where young joints were collected from irrigated specimens, the percentage of dry substance was the lowest ever observed, namely, 9.7 per cent. ${ }^{a}$

It was found that at the time of year when the flower-buds are forming, the acidity of the joints on which they appear is higher than usual and fluctuates irregularly, and consequently such joints were avoided. This applies only to the experiments carried on in the spring of 1911 , since all of the other work was done in the summer long after the flowers had disappeared.

In the plants of Opuntia versicolor there is a considerable range of color, from a clear, somewhat bluish green throughout to a decidedly reddish tint on the upper exposed side, with a lower side green or brownish yellow. Generally the red color is characteristic of flaccid plants, but not always by any means. Casual observation shows that many plants which are distinctly red during the dry period lose a great part of that color when the rains come, but some of the reddest plants have been found among those which are appar- 
ently fully turgid. Repeated tests did not indicate any definite correlation between color and acidity, as no distinct acidity difference appeared between red and green shoots from any one plant. Inasmuch as the dry plants are more often red than not and the turgid ones usually green, there may be some connection which the writer failed to discover. It is not impossible that a diminished water-supply may influence the formation of anthocyan in the epidermis of this species. It would be an interesting question to determine, but would take a closer study of this particular point than could be here attempted. Record was consistently made on plant color, but no data were assembled that could justify a more definite statement than the above.

Since it was obviously necessary to remove the joints from the plant for purposes of experimentation, it became important to ascertain if the wounding incident upon removal induced any traumatic reaction that affected either respiration or acidity. Various experiments were made which showed that so slight an injury as that occasioned by detaching the joints produced no important effect. The averages of four series made in March 1911, showing both the total and pure-juice acidity, give a slightly higher result for the former and practically an identical result for the latter, as is shown in table 4 . Reference to the itemized record in table 7 shows, however, that while the acidity was higher in the detached joints in two experiments, it was lower in the other two. The variations are not more than are to be expected from individual differences without reference to the question of wounding, and may be considered negligible.

TABLE 4.-Average of four series showing acidity of attached and removed joints, March 1911.

\begin{tabular}{|c|c|c|c|c|c|}
\hline & \multicolumn{5}{|c|}{ Time since removal from plant. } \\
\hline & $3 \mathrm{hrs.} 30 \mathrm{~min}$. & $7 \mathrm{hrs.}$ & 23 hrs. & 26 hrs. & $21 \mathrm{hrs}$. \\
\hline Time of day $\ldots \ldots \ldots \ldots \ldots \ldots \ldots$ & $12^{\mathrm{h}} 30^{\mathrm{m}}$ p.m. & 4 p.m. & 8 a.m. & $10 \mathrm{a.m}$. & 4 p.m. \\
\hline $\begin{array}{l}\text { Removed, total acidity per gram fresh } \\
\text { weight in c.c. } \mathrm{N} / 10 \mathrm{KOH} . . . \ldots \ldots\end{array}$ & 0.60 & 0.35 & 0.76 & 0.44 & 0.36 \\
\hline $\begin{array}{l}\text { Removed, acidity pure juice in c.c. N/10 } \\
\text { KOH }\end{array}$ & 0.87 & 0.36 & 1.17 & 1.00 & 0.38 \\
\hline Attached, total acidity per gram fresh & 0.61 & 0.37 & 0.71 & 0.60 & 0.37 \\
\hline 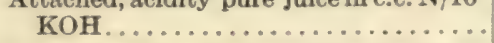 & 0.91 & 0.36 & 1.09 & 0.94 & 0.41 \\
\hline
\end{tabular}

The same results were obtained from a series of four experiments made in July 1912 , in which only the acidity of the juice was determined. The normal rise and fall of acidity is given according to the time of day at which the determination was made, as is shown in table 5.

TABLE 5.-Average of four series of juice acidity in attached and removed joints, July 1912.

\begin{tabular}{|c|c|c|c|c|c|}
\hline & \multicolumn{5}{|c|}{ Time since removal from plant. } \\
\hline & $3 \mathrm{hrs}$. & $6 \mathrm{hrs}$. & $24 \mathrm{hrs}$. & $27 \mathrm{hrs}$. & 30 hrs. \\
\hline 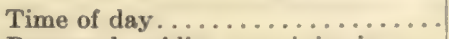 & 1 p.m. & 4 p.m. & 10 a.m. & 1 p.m. & 4 p.m. \\
\hline $\begin{array}{l}\text { Removed, acidity pure juice in c.c. } \\
\mathrm{N} / 10 \mathrm{KOH} . . . \ldots \ldots \ldots\end{array}$ & 0.78 & 0.33 & 1.55 & 0.79 & 0.30 \\
\hline $\begin{array}{l}\text { Attached, acidity pure juice in e.c. } \\
\mathbf{N} / 10 \mathrm{KOH} . . . \ldots \ldots \ldots \ldots \ldots\end{array}$ & 0.75 & 0.33 & 1.54 & 0.81 & 0.31 \\
\hline
\end{tabular}


In order to learn what effect upon the evolution of earbon dioxide the detaching of the shoots might exert, joints which had been removed from the plant for a week, and hence must have fully recovered from any possible wound stimulus, were placed in the Pettenkofer apparatus and their respiration-rate determined. The same joints were then eut at the base as they would be on removing them from the plant and their respiratory-rate was again obtained. No difference in earbon dioxide was observed over a period of hours, so that here, as with the acidity, it is evident that the removal of the joints from the plant causes no measurable wound reaction. The question of wound respiration which follows considerable injury will be considered later. The point under discussion is merely whether the necessary injury done in detaching the joints from the plant need be taken into consideration. It is evident from our experiments that any such effect is negligible. However, to avoid any possibility of traumatic reaction by increased oxygenation of the tissues, and to prevent any undue evaporation of water, the wounds eaused by breaking the joints apart were always painted with vaseline. Finally, it will be recalled that the area of the articulation of one joint with another is not at all large in Opuntia versicolor, nor, indeed, in any of the opuntias.

While it was sometimes convenient to have a considerable supply of material already gathered, particularly when a series was to be run through the night, as a rule the specimens were freshly collected, as after standing there is a noticeable decrease in weight due to loss of water. Under the conditions in the laboratory at Tucson in the spring of 1911 , it was found that 1,014 grams of fresh material of Opuntia versicolor lost, after 10 days' exposure to the air in diffuse light, 138 grams weight. Of course all the material sent from Tucson to New York was subject to this drying process. After gathering there must have been some loss of water, though after the material arrived in New York, care was taken to prevent any further evaporation; indeed in some cases there was a slight gain. In this connection it is interesting to note that the material left unprotected in the laboratory in New York lost water and shriveled far more rapidly than that lying on the tables in Tucson. Whether this was wholly because of the aridity of a steam-heated building is perhaps a question, but there can be no doubt that it was an important factor. The material sent from Tueson to New York arrived, without exception, in excellent condition, and while some was sent as late as November and some as early as March, the weather conditions at the time of transit were such that there could have been no danger of freezing. There was one thing noticeable, however, namely, that under the relatively feeble illumination of a northern winter the acidity showed much less distinet periodicity than it would have shown in its natural habitat For this reason no extended series of acidity determinations were attempted in New York, where the work was confined during the winter chiefly to respiration determinations with the Pettenkofer apparatus and later in the spring to the beginning of the gas-interchange experiments. Many of the latter determinations have not been utilized in the final assembling of data, as these experiments were more for the purpose of getting control of methods than for final results. 


\section{ACIDITY DETERMINATIONS.}

As will be seen, the bulk of determinations of acidity were made with Opuntia versicolor for the reasons already given, but a few series were undertaken with Mammillaria grahami, Carnegeia gigantea, Opuntia discata, and o. blakeana. The first problem was to establish more definitely the course of the well-known periodicity of acidity that is found in such succulent forms. While many of the investigators who have worked on succulents have made some researches into the behavior of cacti, the greatest number have been interested in various crassulaceous forms, notably Sempervivum and Echeveria. It seemed advisable, then, to obtain a complete record of the behavior of a eactus type in this regard, to which end a number of series, embracing complete 24-hour periods, were undertaken in order to plot the diurnal decrease and nocturnal increase of the acid content of the tissues.

\section{PERIODICITY IN ACIDITY.}

Three complete sets, composed of two or more separate series, shown in tables 8, 9, and 10, were carried through in March and April 1911, at Tucson. The acidity in these experiments was taken at 2-hour intervals over somewhat more than 24 hours. In addition, two partial sets, extending from early morning to late in the evening, over a period of 16 hours, as shown in tables 11 and 13 , were made late in June 1913. Of this pair the last (table 13) was with young joints, the other with mature-turgid ones. The acidity was recorded hourly except at the end, but for lack of time only the pure juice was determined. All of these experiments tell the same story, namely, the marked diminution of acidity during the daylight hours and the slow increase during the night until the maximum is reached at about sunrise. These facts are in accord with the general ones already well known. In addition, numerous other determinations were made, all of which indicate a similar periodicity, which will be discussed in their proper place.

It will be seen that in general the differences between maximum and minimum are greatest in the summer time, as, indeed, would be expected. When the plants are supplied with water they are most active during that season, and as the sunlight is stronger and the temperature higher, any effect of these factors on the acidity would be more marked. In the three series of March and April 1911 (tables 8, 9, and 10) the maximum acidity per gram fresh weight is somewhat more than twice that of the minimum, the actual ratios of the three series being 1.48 to $0.67,0.76$ to 0.31 , and 0.70 to 0.31 , respectively. These may be compared with the results shown in table 13 for mature-turgid joints, where the maximum acidity is to the minimum as 3 to 1 (actually in the average of the three series, 29 to 10). It will be observed, also, that in these experiments the acidity was taken as late as $10^{\mathrm{h}} 30^{\mathrm{m}}$ a. m., which was some hours after the highest point had been reached. This increase in ratio is even more prominent in the acidity of the pure juice, where in the spring the maximum is to the minimum as 3 to 1 (table 10), while in the summer the ratio is more nearly 7 to 1 (tables 11 and 12 ).

From these experiments it would also appear that in the summer there is a greater difference between the total acidity per gram fresh weight and the acidity of the pure juice per cubic centimeter than during the earlier months. 
In other words, while the actual amount of acid contained in the tissues is not very different at the two seasons the juice itself is less concentrated during the summer rainy season and consequently there must be more water held in the plant.

One very interesting fact indicated in table 6 is that, with increasing acidity, there is a very distinct tendency for the dry-weight acidity to increase more rapidly than that of the juice. Table 6 gives the averages of the dry and fresh weight total acidity and also the juice acidity, the basis of the arrangement being the dry weight. The higher acidities, above 4 c.c. decinormal alkali per gram dry substance, show a sharp increase of the total acid-content over the concentration of the juice, so that the ratio of the former to the latter, instead of being less than 3 to 1 , is more than 4 to 1 , a point that is most con-

TABLE 6.-Average acidity of 103 determinations, arranged in groups according to dry-weight acidity.

\begin{tabular}{|c|c|c|c|c|c|c|c|}
\hline Age of material. & $\begin{array}{l}\text { Acidity groups } \\
\text { according to } \\
\text { acidity per } \\
\text { gram dry } \\
\text { weight. }\end{array}$ & $\begin{array}{l}\text { Deter- } \\
\text { mina- } \\
\text { tions. }\end{array}$ & $\begin{array}{l}\text { Aeidity } \\
\text { per } \\
\text { gram } \\
\text { dry } \\
\text { weight. }\end{array}$ & $\begin{array}{l}\text { Acidity } \\
\text { per } \\
\text { gram } \\
\text { fresh } \\
\text { weight. }\end{array}$ & $\begin{array}{c}\text { Ratio of } \\
\text { acidity dry } \\
\text { to } \\
\text { acidity fresh. }\end{array}$ & $\begin{array}{c}\text { Acidity } \\
\text { per } \\
\text { gram } \\
\text { juice. }\end{array}$ & $\begin{array}{c}\text { Ratio of } \\
\text { acidity dry } \\
\text { to } \\
\text { acidity juice. }\end{array}$ \\
\hline \multirow{7}{*}{ Young......... } & $(1.00$ and below & 7 & 0.77 & 0.15 & 5.1 & 0.27 & 2.9 \\
\hline & $1.01-2.00$ & 7 & 1.64 & 0.29 & 5.7 & 0.78 & 2.1 \\
\hline & $2.01-3.00$ & 8 & 2.59 & 0.42 & 6.2 & 0.86 & 3.0 \\
\hline & $3.01-4.00$ & 7 & 3.52 & 0.55 & 6.4 & 1.19 & 3.0 \\
\hline & $4.01-5.00$ & 6 & 4.78 & 0.73 & 6.5 & 1.36 & 3.5 \\
\hline & $5.01-6.00$ & 4 & 5.43 & 0.84 & 6.5 & 1. 30 & 4. 2 \\
\hline & $6.01+$ & 4 & 6.45 & 1.05 & 6.1 & 1.50 & 4.3 \\
\hline \multirow{7}{*}{ Mature-turgid... } & (1.00 and below & 5 & 0.68 & 0.13 & 5.2 & 0.29 & 2.3 \\
\hline & $1.01-2.00$ & 17 & 1.64 & 0.32 & 5.1 & 0.72 & 2.3 \\
\hline & $2.01-3.00$ & 5 & 2.36 & 0.45 & 5.2 & 0.96 & 2.5 \\
\hline & $\{3.01-4.00$ & 8 & 3.55 & 0.75 & 4.7 & 1.32 & 2.7 \\
\hline & $4.01-5.00$ & 4 & 4.98 & 0.92 & 5.4 & 1.24 & 4.0 \\
\hline & $5.01-6.00$ & 5 & 5.36 & 1.12 & 4.8 & 1.56 & 3.4 \\
\hline & $6.01+$ & 1 & 6.50 & 0.98 & 6.6 & 1.50 & 4.3 \\
\hline \multirow{2}{*}{ Mature-flaccid. . } & $\{1.00$ and below & 26 & 0.67 & 0.21 & 3.2 & 0.39 & 1.7 \\
\hline & $1.01-2.00$ & 9 & 1.53 & 0.44 & 3.5 & 0.78 & 2.6 \\
\hline
\end{tabular}

sistently shown in the averages of the acidity of young joints, though it is also indicated in those of the mature-turgid ones. In the group which includes the examples of highest acidity (over 6.00 per gram dry weight) with both the young and mature-turgid joints the ratio is 4.3 to 1 .

It is true that with the mature material the ratio of the next preceding group falls considerably below that which is required, owing presumably to the fact that 2 of the 5 examples averaged had an unusually high juice acidity. If these are omitted the ratio is similar to that found with young joints of equal acidity. The variations in the acidity of the flaccid joints are much less than with the others, so that on this basis of classification into acidity groups the determinations fall into only two divisions and the vast majority of the examples come in the group with the lowest acidity. Nevertheless, as far as the ratio of dry weight to juice acidity is concerned, we find a difference between the two groups similar to that already described. The same relation of acidi- 
ties shows in the averages of the determinations given in table 12. The ratios of the dry-weight acidity to the concentration of the juice are as follows: for the young joints, high acidities 4.2 to 1 , low acidities 3.3 . to 1 ; for the mature joints, high acidities 3.4 to 1 , low acidities 2.3 to 1 .

The obvious explanation of this phenomenon would seem to be that with high-acidity content there is an increased amount of water present in the tissues, which would of course affect the concentration of the juice without influencing the total acidity. This is also borne out by the relation of dry and fresh weight acidity as it is seen in the young material. The increase of acidity on the basis of fresh weight is not so great as on the basis of the dry weight, or, in other words, the ratio of the acid-content of the latter to that of the former rises as the acidity increases. It must be admitted, however, that in the series with the old turgid material this increase in ratio does not show very satisfactorily, except in the highest acidity determination. However, it is probable that the explanation is that which is indicated above, namely, that as the acidity rises the amount of water in the tissues increases, so that the concentration of the juice itself, while higher, does not rise as rapidly as does the total amount of acid present. This whole question is an interesting one in connection with the idea promulgated by Borowikow ${ }^{a}$ and mentioned. by Spoehr and would be worthy of closer examination than is given here. According to Borowikow, there should be an increase in proportional watercontent as the acidity rises because of the increased hydratation of the protoplasmic colloids. The same effect, however, could be equally well accounted for by the older assumption of the relation of turgor pressure to the quantity of water contained by a tissue. The increased acid indicates, of course, that the osmotic coefficient of the cells must be higher, and consequently their ability to take in water must be greater. It is not impossible that both may play their parts. It would be highly profitable to make a more detailed study of this point.

With due regard to the time of day at which the determinations were made, it may be said in general that the young joints just forming show not only a higher acidity than the older joints from the same plant, but also greater oscillation. As an illustration of this, the lowest acidities obtained were in young joints which had been exposed during the day. Mature-flaccid joints, which are probably as nearly inactive as the plant ever becomes, show on the average the lowest acidities and the least range of variation therein. All things considered, the fully mature but still turgid joints may be taken to represent the normal condition of the plant as a whole, since they form the bulk of the active tissue even during the growing season, when the young joints are fairly plentiful. After the young growth has attained its full development during the first season it undoubtedly must lose its higher acidity and greater respiratory activity, a circumstance which will be discussed later. At what period the maturation of the tissue occurs would form an interesting subject for investigation. The time probably comes during the dry aftersummer, perhaps very shortly after the cessation of the summer rains. The writer has never been at Tucson at this period, and consequently has not considered this question.

${ }^{a}$ Borowikow, G. A. Ueber die Ursachen des Wachstums der Pflanzen. Biochem. Zeitschr., vol. XLrv, p. $230,1913$. 
Returning to the young joints, it is not remarkable that they should show a higher average acidity than the mature tissue, for, as will be seen later, their oxidation processes must be going on at a more rapid rate, as also is the photosynthesis, which must in the last analysis afford the material from which the acid is formed. In the same way, the greater fall of acidity in young tissue is also probably due to the more active oxidation. It is not at all impossible, also, that the acid destruction may be favored by the more delicate nature of the young epidermis, which would allow of greater penetration of the sun's rays and thus bring about more rapid deacidification. The elongation of the young joints after the bud begins to develop is exceedingly rapid if the conditions be suitable, but after the first season those of Opuntia versicolor at least do not grow greatly in length.

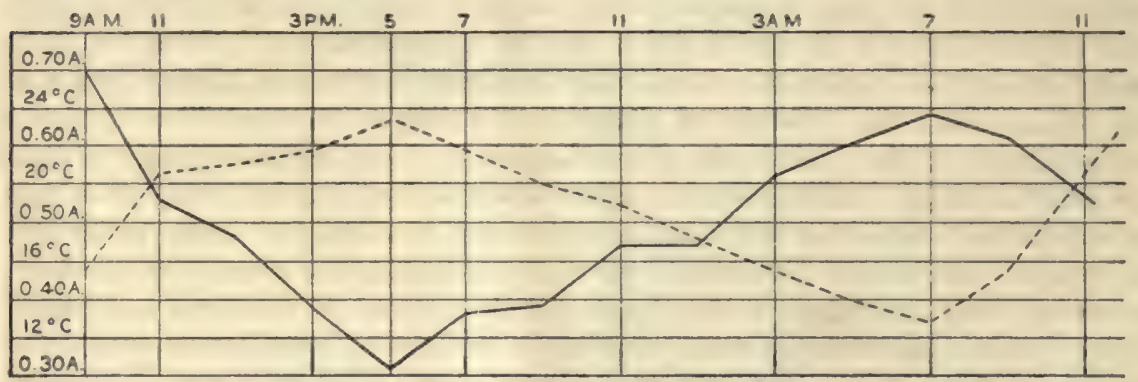

FIG. 2.-Graph showing acidity of Opuntia versicolor in terms of c.c. of decinormal alkali per gram fresh weight.

$=$ acidity.

$=$ temperature.

The ordinates read for either acidity or temperature. Thus $0.30 \mathrm{~A}$ signifies an acidity of that amount or also stands for $10^{\circ} \mathrm{C}$. temperature, similarly $12^{\circ} \mathrm{C}$. may read as well as 0.35 acidity. The plants were in the open and uncovered. Average of experiments in table 8.

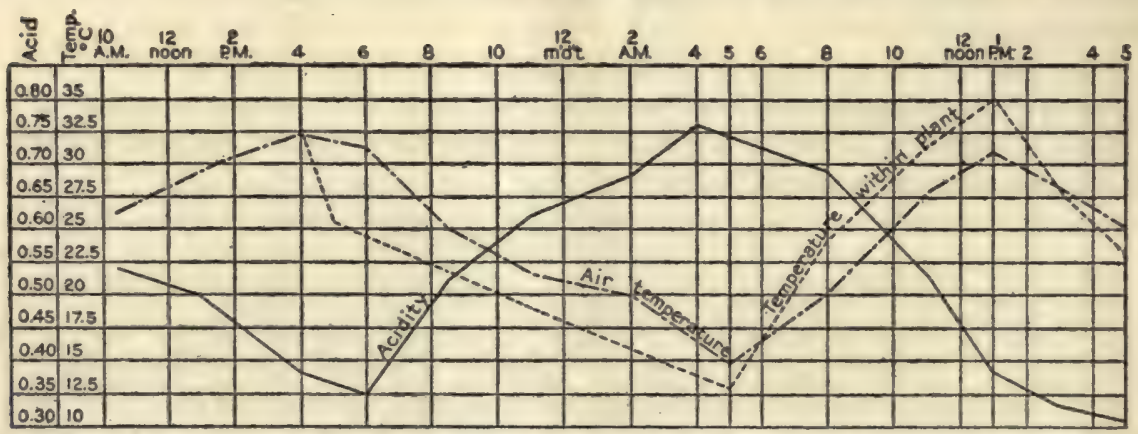

F1G. 3.-Graph showing acidity of Opuntia versicolor in terms of c.c. of decinormal alkali per gram fresh weight, in comparison with diurnal change of temperature of air and of tissues within the plant.

$$
\longrightarrow \text { acidity. }
$$

- temperature within the plant.

The ordinates read for either acidity or for temperature. Plants in the open, uncovered. Average from experiments in table 9.

From the accompanying graphs (figs. 2 and 3), which have been made from the experiments set forth in tables 8 and 9 , it may be seen that the diurnal course of acidity runs almost opposite to that of temperature, from which, however, it should not be assumed that temperature is necessarily the only 
conditioning factor, since the increase of light is eoincident with the increase in heat. The temperatures given in these graphs are those of the normal outdoor conditions. One especially interesting series is that shown in table 9 , where, in addition to the air temperature, there is given that of the interior of the cactus joint. The latter was taken by inserting into the joint a thermometer of very small diameter, which was allowed to rest before observations were made, until any possible traumatic effect had become negligible. The graph follows that of the air temperature in a general way, but differs in the important fact that the range is greater. Its maximum is higher and its minimum is lower than those of air temperature. In short, it crosses the graph of the latter twice. This phenomenon concerning temperatures within cacti was observed by Shreve ${ }^{a}$ in the case of Carnegiea gigantea, and is perhaps universal in these fleshy plants. What its significance may be is hard to say. It is not difficult to understand why the maximum within the cactus joint should rise above that of the outside air, because of heat absorption and possibly to a small extent increased metabolic activity, but it is not so easy to explain why the minimum should fall below. It is perhaps possible that this depression of temperature should be ascribed to transpiration, although the activity of eacti in this respect is notably low. The reason could hardly be found in endothermic chemical reactions. The accumulation of acid which is taking place during this time is presumably due to oxidation processes, which, while they may be only partial as compared with those that take place in ordinary plants, are nevertheless exothermic in their nature. A closer examination of this temperature relation would be of considerable interest. As far as we are concerned at the moment, the point is to emphasize the difference between the acidity and the temperature curves.

These results which have just been discussed had for their object the presentation of the complete diurnal curve of acidity under the natural conditions which surround the plant, the complete course of which has not been plotted in a detailed fashion for any succulent plant. The oscillations in acidity are known to be affected most importantly by light and temperature, and a number of experiments were made in which these two factors were isolated as far as possible, as is set forth below.

\section{EFFECT OF LIGHT ON ACIDITY.}

The method for exposing the joints to sunlight without the attendant difficulty of overheating has already been described in the account of experimental methods. It suffices to say here that the plants were kept at temperatures low enough to obviate effects on acidity due to heat and yet exposed to direct sunlight as it filtered through the glass receiver. The temperatures used varied from $5^{\circ}$ to $20^{\circ} \mathrm{C}$., which, as subsequent discussion will show, is below the point where heat markedly affects the amount of acid present. Under such conditions there is a decided drop in acid-content after exposure for several hours in the bright sun. The average acidity of the juice in all of the experiments made in this manner (table 14) was in the beginning 1.40 per cubic centimeter, but fell at the end of the exposure to 0.74 for the same amount. There was thus a drop of practically 50 per cent. This is not, indeed, as great a diminution

aShreve, F. The influence of low temperatures on the distribution of the giant cactus. Plant World, vol. 14, p. 136, 1911. 
as shown in the control experiments which were not inclosed in glass, where, at the end of a similar exposure, the acidity amounted to only 0.36 per cubic centimeter juice, or not much more than 25 per cent of the original quantity. It must be remembered that in the latter case the material was under the action of light free from any screen whatsoever, and also under the influence of the outside temperatures, which were higher in all cases than those within the cooled glass chambers. It would be better, indeed, to expose the material in quartz containers or under some form of glass which allowed all of the sunlight to pass through, in which manner the full effect of the sunlight could be obtained.

A more detailed analysis of the figures from these experiments shows that the range of acidity was greater in the young shoots used than with the older ones. In the young tissues an average shows the initial acidity to have been 1.70 per cubic centimeter pure juice, which fell to 0.71 ; while the mature joints, which in the beginning stood at 1.27 , dropped only to 0.76 per cubic centimeter juice. There does not seem to have been any marked effect of the temperature, though there was a slightly less proportional drop at $5^{\circ}$ to $6^{\circ} \mathrm{C}$. than at $20^{\circ} \mathrm{C}$. As has already been said, the temperatures were all below the critical point where this factor markedly affects the disintegration of the acids.

\section{EFFECT OF TEMPERATURE ON ACIDITY.}

The series to test the effect of temperature alone were, of course, kept in the dark. Here not only was the action of heat on the decrease of acidity studied, but also upon its increase.

The results of experiments with mature joints that have a relatively high acidity showed that at $20^{\circ}$ to $30^{\circ} \mathrm{C}$, after several hours' exposure, there is only a slight decline from the original amount of acid; but at $40^{\circ} \mathrm{C}$., on the other hand, the decrement is nearly half (table 15).

The actual averages of the various experiments are as follows: initial acidity, 1.32 per cubic centimeter juice; final acidity at $20^{\circ} \mathrm{C} ., 119$; at $30^{\circ} \mathrm{C}$, 1.24 ; at $40^{\circ} \mathrm{C}, 0.79$. With young joints under similar conditions the same phenomenon is noticed, with the exception that at $20^{\circ} \mathrm{C}$. there is an increase. The figures are as follows: initial acidity, 1.58 per cubic centimeter juice; final acidity at $20^{\circ} \mathrm{C}, 1.67$; at $30^{\circ} \mathrm{C}, 1.45$; at $40^{\circ} \mathrm{C} ., 0.81$. As in the case with mature joints, the decrease at $40^{\circ} \mathrm{C}$. is nearly 50 per cent. The difference of the response of the old and young tissue at $20^{\circ} \mathrm{C}$. is interesting, the latter showing a rise in acidity at that temperature, and even at $30^{\circ} \mathrm{C}$. an increase was noted in the young joints in one instance. The reason may be that the young joints were probably not so near their highest possible acidity, while the old joints were; consequently the equilibrium of the latter was more easily disturbed, with the resultant natural tendency for the acidity to fall when it has accumulated to its maximum. It is known from the results of de Vries and others that continued darkness tends, other things being equal, to induce a diminution of acidity; but from the experiments cited above it is evident that, aside from any influence the protracted absence of light may have on tissue of high acid-content, the decrease is hastened by rising temperature. When it comes not to the decrement of acid in material of high acidity, but to the increment of it in plants where it is already low, that of the three temperature ranges employed, the accumulation of acid in both young and old tissue is 
greatest at $30^{\circ} \mathrm{C}$. and least at $40^{\circ} \mathrm{C}$. (table 15). According to the figures shown in the table, mature joints with an average initial acidity of 0.24 per cubic centimeter juice show accumulation of acid after $18 \frac{1}{2}$ hours to the following amounts: at $20^{\circ} \mathrm{C}$., 1.15 ; at $30^{\circ}$ C., 1.54 ; at $40^{\circ}$ C., 0.62 . Similarly the younger parts, which had an average initial acidity of 0.24 per cubic centimeter juice, showed during the same period the following gain: at $20^{\circ} \mathrm{C} ., 1.44$; at $30^{\circ} \mathrm{C}$., 1.74; at $40^{\circ} \mathrm{C}$., 0.75 . As with the acidity decrease, the younger tissues are more active than the older ones, but the difference is not very great.

The results of earlier determinations made in 1911 of the accumulation of acid in mature joints, extending over much longer periods and at greater range of temperature (table 16), are not directly comparable with those just discussed, for in these cases only total acidity and not juice acidity is given. The greatest accumulation of acid took place at $7^{\circ} \mathrm{C}$. where, after 96 hours, the acidity was 1.38 per gram fresh weight, or somewhat more than double the initial acidity of the sample. The shorter the period of exposure the higher the temperature at which the maximum is found. After 18 to 24 hours it was at $20^{\circ} \mathrm{C}$.; at $31^{\circ} \mathrm{C}$. the acidity remained nearly at its initial point, but on the whole it falls the longer the exposure. At $47^{\circ} \mathrm{C}$. there is a decrease for every period, and after 96 hours at that temperature the acidity had sunk to half of its original amount. In other words, at low temperatures, while the acid is formed slowly, it is also broken down even more slowly and hence accumulates to a greater degree; while at high temperatures it is formed less rapidly and is broken down faster and hence diminishes instead of increasing. These experiments also bear out what has been reported by previous investigators regarding the effect of long-continued darkness. The series at $20^{\circ} \mathrm{C}$. is a good illustration. After 69 and still more after 96 hours of darkness at that temperature a decrease of acidity from the point that was attained at 18 hours is shown.

That the plants are affected by the normal meteorological changes was a matter of common observation. After a cool night in summer, the acidity of the tissues on the following morning was noticeably higher than when the night had been warm. Similarly the effect of relatively low temperatures during the day, not above $27^{\circ} \mathrm{C}$., especially when accompanied with a dull, overcast sky, was to maintain a higher degree of acidity than normal. On July 17,1912 , when these conditions were realized, the average acidity of the juice from six different plants at $1 \mathrm{p}$. $\mathrm{m}$. was 1.23 per cubic centimeter; the same plant a few days later, when the sky was clear and the temperature much higher, gave an average acidity of only 0.65 at the same hour. Again on July 24, when the day had been relatively cool and dull, three plants gave an average acidity of 1.15 per cubic centimeter of juice at 4 o'clock in the afternoon, the hour at which acidity is usually at its minimum; subsequently, on a bright, warm day the acidity was only 0.32 at the same time. From these data it appears that the acid-content of the plants is sensitive to the immediate fluctuations in the external conditions and that induced after-effects of the normal periodic changes are not to be anticipated. None of the experiments exposed for long periods in the dark at constant temperatures shows any indication that there is a persistence of periodicity in acidity beyond the immediate effect of the factors which caused it. Special experiments to reveal any derived periodicity did not in any case indicate diurnal oscillations other than those caused by illumination and temperature. Material of low acidity, when 
placed in the dark, shows an increase of acid up to a certain point, which is followed by a slow decrease if the darkness is prolonged. Material of high acidity under similar conditions commonly shows a slow decrease. Such results are not surprising when it is understood that the most important part of the process of deacidification is a photolytic one. Experimentally considered, this close connection of acidity with weather conditions gives an exceedingly small expectation of precisely similar results from day to day, even with material from the same plant.

Owing to such causes difficulties in the comparison of different series tend to increase, and the necessity of making large numbers of observations in order to obtain reliable averages is obvious. Even under apparently like conditions the plants are not constant in acidity. No attempt was made to discover to what causes fluctuations of this kind were due, and while some might be more or less easily traced others are probably very obscure. It is possible that there may be a correlation between degree of acidity and transpirationrate, and certainly the amount of water held at any one time in the tissues would affect the acidity of the pure juice, even if it did not greatly influence the total amount of acid. To establish points of this nature would require further investigations with a large number of experiments designed to bring out such relationships. In this work no especial effort was made to go further into the matter than has been indicated.

\section{EFFECT OF INCREASE AND DECREASE OF OXYGEN SUPPLY.}

While deacidification has, for a long while, been considered an oxidation process, it was not until the appearance of Spoehr's work that we were informed in what manner this process proceeded. His experiments, however, were not with the living plant, so that the behavior of the acid in Opuntia versicolor in atmosphere containing more or less oxygen than air is of especial interest.

Various trials were made with joints in atmospheres practically devoid of oxygen, in those in which the oxygen had been cut to a few per cent, and in others containing 75 to 80 per cent of the gas. The first were with material sent from Tucson to New York, and the reactions, while not as marked as those carried on in the natural habitat of the plant, are worthy of record. This series of determinations is shown in table 17 , series I. The material was exposed in an atmosphere of hydrogen, 97 per cent pure. The balance of 3 per cent was presumably air, which gives a concentration of oxygen of 0.6 per cent, which is almost negligible. Analyses of the atmosphere of the receiver at the end of the experiment showed no trace of oxygen, which must have disappeared almost at the outset. Under these conditions there is a small but well-marked increase in the acidity of the juice of approximately 15 per cent. The increase in total acidity is not quite so great, amounting in the average of the six experiments to 12 per cent. A similar series is shown in table 17, series II, but with the addition of experiments in a 75 to 80 per cent atmosphere of oxygen. In this set the gain of acidity in an atmosphere of hydrogen is somewhat more marked than in series I. In the atmosphere enriched with oxygen there is a distinct fall in acidity, amounting to 27 per cent. But in none of the experiments made in New York were the reactions as well marked as in the experiments carried on at Tueson. It must be remem- 
bered that the New York temperatures were not as high as those at Tucson, but still it is evident that in the study of these plants it is highly necessary to check all results with those from work carried on in the natural habitat of the plant.

In the Tucson experiments (table 18) exposure to 75 to 80 per cent oxygen was followed by a more than 50 per cent decline in acidity, showing very plainly that under fairly constant conditions of temperature and in the dark the oxidation of the acids will proceed more rapidly when an excess of oxygen is supplied. In ordinary air, under the same conditions, the diminution of acidity was considerably less, though still well marked, but in pure hydrogen it was maintained at almost its original point. As in these specimens the initial acidity was high-probably near its maximum - it would hardly be expected that actual rise of acid-content would be shown in the hydrogen atmosphere, even if such a phenomenon commonly takes place. It may be noted, however, that one experiment does show such a slight increase. The actual figures averaged from this set of experiments are as follows: for mature joints with an initial acidity of the juice of 1.32 per cubic centimeter, exposure for from 22 to 30 hours in air at about $30^{\circ} \mathrm{C}$. gave an acidity of 0.96 ; in oxygen an acidity of 0.60 , and in hydrogen one of 1.18 . Young joints under practically the same conditions showed the following changes from the initial juice acidity of 1.84 per cubic centimeter: to 1.17 in air, to 0.66 in excess oxygen, and to 1.75 in pure hydrogen.

From the next group of experiments (table 19), made on material of low initial acidity, it may be seen how the presence or absence of oxygen affects the accumulation of acid in the tissues. The average acidity of the pure juice at the beginning of the experiment was for the mature joints 0.23 per cubic centimeter and for the young ones 0.48 per cubic centimeter. This rose under the conditions of the experiment to 0.93 and 1.65 respectively, when the material was exposed to normal air. In hydrogen atmosphere the rise for the same length of time is to 1.07 for old and 1.57 for young. In excess of oxygen amounting to 75 to 80 per cent at the end of the experiment, the acidity of the mature joints had risen slightly, being 0.37 , but in the young material it was practically the same as at the beginning, being 0.46 . It is to be observed that in one of the three experiments the acidity rose perceptibly, but in the other two it fell. The average initial acidity indicated for the mature joints is exceedingly low, and the apparent rise in the oxygen atmosphere is probably no more than that represented by individual differences of the material used; at all events, in neither the young nor the mature specimens is the change of acidity of significant magnitude.

In an excess of oxygen, then, the acidity does not rise in material of low initial acidity; it shows no decrease, however, presumably because the minimum has already been attained. In hydrogen, on the other hand, there is an accumulation of acid of essentially the same amount as in normal air. This last result, as shown by this series of experiments, is not, indeed, in agreement with what others, particularly Astrue, have found with different succulents. It was, however, no surprise to have found such a marked increment in acidity in the absence of oxygen. Of course, at the beginning of the experiment, as has been explained in other cases, there remained a small percentage of oxygen, but not enough to account for the appearance of so large a quantity of acid 
by oxidation from outside. It will be shown later that the so-called intramolecular respiration of this cactus form is remarkably high, and it must be supposed that the acidity is maintained or increased by such activity, just as it is by normal aerial respiration. That there is so considerable a fall of activity in the presence of an excess of oxygen is no more than would be expected in view of the probable manner of acid formation in these plants. There is evidently no support in these experiments for the claim that Astruc makes to the effect that with an enriched oxygen supply the formation of acid is encouraged.

As the experiments described above were all carried on in the absence of light, a supplementary series was made where, under the same conditions, the plants were exposed to diffuse light. Here in the presence of excess oxygen the acidity falls to a lower point than under normal conditions, while in the absence of that gas it is maintained at somewhere near its initial amount, although there is a slight decrease. This material was exposed to daylight for the major portion of 2 days (table 20). With an initial acidity of 1.25 per cubic centimeter pure juice the mature joints, after exposure as indicated above, gave in air an acidity of 0.60 . In the absence of oxygen it diminished only to 0.96 , while with greatly increased oxygen pressure it fell to 0.39. The young joints behaved in a similar fashion. With them the initial acidity was higher, namely, 1.76 ; in ordinary air it fell to 0.46 , while in oxygen it was as low as 0.38 . As in the dark, there was a much smaller diminution in atmospheres of hydrogen, the acidity amounting to 1.23 per cubic centimeter. With the supply of oxygen less than in air, but still amounting to as much as 10 per cent, there is no marked difference from the normal in the acidity, but at a concentration of 5 per cent the effect of the lesser oxygen supply begins to manifest itself.

Behavior of acid formation in light seems to accord with that found in continued darkness. The greater decline of acidity in absence of illumination is entirely what might be expected when the effect of the light in deacidification is recalled. Nor is it difficult to account for the greater decline in the specimens exposed to hydrogen. In the light, of course, the photosynthetic activity of the plant supplied oxygen for the splitting of the organic acids, but that this supply was limited is shown by the comparatively partial deacidification, a fact that is somewhat significant, suggesting as it does how relatively feeble the photosynthetic activity of plants of this type must be. In all but one of the cases given, the degree of acidity after exposure to an increased supply of oxygen was about that which experience teaches is the natural minimum. In other words, the action of the oxygen was to carry the breakingdown of the acids as far as it could be carried. In normal air no such limit was reached, nor, indeed, could it be expected that the illumination afforded by diffuse light would be sufficiently effective. The influence of the excess oxygen is in the direction of hastening the deacidification, but not beyond a certain minimum.

\section{EFFECT OF INJURY ON ACIDITY.}

Wounding, which has the effect of increasing the area directly exposed to the air, has somewhat the same effect as does excess of oxygen. A number of experiments were tried to show this point (table 21). A sharp decline in acidity of more than 25 per cent was noticed 24 hours after injury and this 
decrease was maintained up to 60 hours, after which a slight rise was to be noticed. This last-named circumstance may very well be due to the fact that after $2 \frac{1}{2}$ days the wound periderm had formed sufficiently to protect the cut surfaces. The subsequent experiments with wound respiration bear out this probability. The acidity of a parallel specimen, which had not been wounded, shows the ordinary slight decrease in acidity which comes as a result of longcontinued darkness. It may be inferred that this diminution of acid is largely the effect of the increased exposure to the oxygen of the air consequent on the injury.

\section{MISCELLANEOUS.}

In tests made to determine the region of highest acidity it was found that the cortex is usually more acid than the pith, while leaves are of about the same acidity as the outer layers. Young fruits did not show the increased amount of acid that might be expected, though they do perhaps contain somewhat more acid than the ordinary tissues. It did not appear that the acidity varied to any noticeable extent in different parts of any one joint. A long, young joint showed at the base a similar acidity to that at the tip. Similarly, none of the mature joints that were tested showed any indication of inequalities in the longitudinal distribution of the acids.

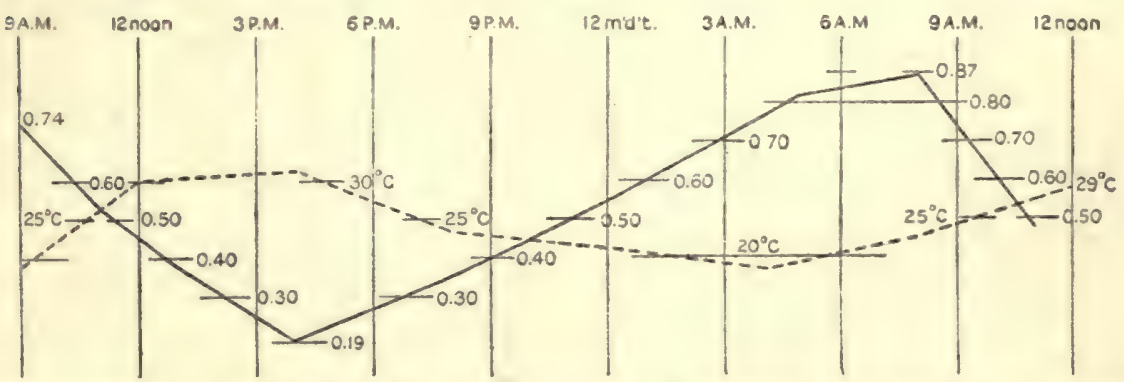

FIG. 4.-Graph showing acidity of Mammillaria grahami in comparison with diurnal temperature curve. The acidity is given in terms of c.c. of decinormal alkali per gram fresh weight. = acidity.

Attention has already been called in the chapter on experimental methods to the differences of acidity in shoots of unequal ages. The young growing joints are distinctly more acid, on the average, than the mature ones, both as to the total amount present and as to the concentration of the juice. Shoots of the age of 1 or 2 years are hardly separable on the basis of their acidity, but at 3 years there is some decline in total acidity (table 22). This may very well be due to the increase of woody tissue, which would greatly increase the dry weight and hence diminish the total acidity per gram. The acidity of the pure juice is practically identical at 1,2 , and 3 years, which would indicate that the activity of the living tissue is of the same magnitude in all three years. In the two instances where shoots bearing flower-buds were used the acidity was found to be considerably higher, showing that in this condition the tissues are probably more active. The investigation made to ascertain possible localization of acidity was not at all complete. The tests were more for the purpose of deciding what precautions should be observed in the selection of material 
for experiment than for any other reason. No determinations at all were made of the acidity of tissues more than 3 years old, though it is highly probable that whatever differences they might show would be along the same lines indicated in the 3 -year-old shoots.

The periodicity of the acid content of cacti other than Opuntia versicolor was touched on in a number of experiments which are set forth in tables 23,24 , and 25. In table 23 are given the results of three series with Mammillaria grahami over a period of 26 hours with determinations at intervals usually of 2 hours. The graph which is shown in figure 4 is from an average of these three series and is essentially the same as that determined for Opuntia versicolor. Of necessity each determination was made with a separate plant, since the individuals of this species are not large. Hence the curve does not, as in the experiments with Opuntia versicolor, represent the activity of single individuals and for that reason may show irregularities due to the variation of different specimens. Nevertheless, the decline and rise of the acidity is plainly indicated. So far as the extraction of the juice is concerned, Mammillaria grahami is perhaps better than Opuntia versicolor, as there is an entire absence of glutinous matter. It is, however, not sufficiently common to allow of its extensive use in experiments.

A few determinations, made at three periods during the day, of Opuntia leptocaulis, $O$. discata, and $O$. blakeana, are shown in table 24 . The decline that is to be expected during the course of the day shows clearly. In all of these, however, the amount of glutinous substance is very large and the acidity determinations are more relative than absolute. However, there is plainly less acid at $4 \mathrm{p} . \mathrm{m}$. than at $9 \mathrm{a} . \mathrm{m}$. The actual averages of the experiments shown are as follows: At $9 \mathrm{a} . \mathrm{m}$. three determinations of 0 . leptocaulis had the fresh-weight total acidity per gram of 1.85; at noon it had sunk to 1.07, and still later, at 4 p. m., it was only 0.83 , a marked decline, though not so great as that found in $O$. versicolor. Similarly three sets of $O$. discata gave an acidity at 9 a. $\mathrm{m}$. of 0.98 ; at 12 noon of 0.69 , and finally at 4 p. m. of 0.35 . The single series with $\mathrm{O}$. blakeana is similar in rise and fall of acidity.

The series with Carnegiea gigantea are somewhat more fragmentary. Five sets of determinations were made between April 5 and 26, 1911, in which, however, both total and juice acidity were determined. At the 3 hours taken, namely 9 a. m., 12 noon, and 4 p. m., the total acidity per gram was respectively $0.79,0.59$, and 0.43 , while the juice acidity per cubic centimeter, taken simultaneously, was $0.91,0.68$, and 0.49 . Thus here, as in the other cases, there was the characteristic drop in acidity as the day advanced.

All of these miscellaneous experiments corroborate the more elaborate results with Opuntia versicolor, and unquestionably the same reactions would be observed in these cases as were found in the latter species. 


\section{EXPERIMENTAL DATA ON ACIDITY DETERMINATION.}

TABLE 7.-Effect of removal from plant of acidity of joints of Opuntia versicolor. Tucson, March 1911 and July 1912.

Acidity of material direct from living plant compared with that from joints which had been detached but exposed under otherwise similar conditions. The wound surfaces where the joints had been separated were not in this case painted with vaseline. In the first series the total acidity of a 50-gram sample and the acidity of the pure juice per cubic centimeter are given; in the second series only the juice acidity is indicated. Acidity is given in terms of cubic centimeters of $\mathrm{N} / 10 \mathrm{KOH}$.

Series I. March 20-21, 1911.

\begin{tabular}{|c|c|c|c|c|c|}
\hline & \multicolumn{5}{|c|}{$\begin{array}{l}\text { Time of determination and hours since } \\
\text { beginning of experiment. }\end{array}$} \\
\hline & $\begin{array}{l}12^{\mathrm{h}} 30^{\mathrm{m}} \\
\text { p.m. } \\
3 \frac{1}{2} \text { hrs. }\end{array}$ & $\begin{array}{l}4 \text { p.m., } \\
7 \text { hrs. }\end{array}$ & $\begin{array}{l}8 \text { a.m. } \\
23 \mathrm{hrs} .\end{array}$ & $\begin{array}{l}10 \text { a.m. } \\
25 \text { hrs. }\end{array}$ & $\begin{array}{l}4 \text { p.m., } \\
31 \text { hrs. }\end{array}$ \\
\hline \multicolumn{6}{|l|}{$\begin{array}{l}\text { Mature-turgid; Initial acidity; total, } 31.55 \text { per } 50 \\
\text { grams; juice, } 0.98 \text { per c.c. : experiment begun } \\
\text { at } 9 \text { a.m. }\end{array}$} \\
\hline Detached; total acidity. . . . . . . . . . . . . & 28.80 & 17.40 & 36.20 & 32.70 & 19.10 \\
\hline Detached; acidity juice per c.c........... & 0.81 & 0.32 & 1.11 & 0.98 & 0.36 \\
\hline Attached; total acidity ................ & 28.30 & 17.30 & 30.80 & 29.30 & 18.90 \\
\hline Attached; acidity juice per c.c........... & 0.82 & 0.30 & 0.99 & 0.91 & 0.38 \\
\hline \multicolumn{6}{|l|}{$\begin{array}{l}\text { Mature-turgid; Initial acidity; total, } 31.55 \text { per } 50 \\
\text { grams; juice, } 1.08 \text { per c.c.: experiment begun } \\
\text { at } 9 \text { a.m. }\end{array}$} \\
\hline Detached; total acidity . . . . . . . . . . . . . . & 31.15 & 18.10 & 39.40 & 31.05 & 17.50 \\
\hline Detached; acidity juice per c.c........... & 0.94 & 0.41 & 1.23 & 1.02 & 0.40 \\
\hline Attached; total acidity . . . . . . . . . . . . . & 33.20 & 19.30 & 39.85 & 30.80 & 18.50 \\
\hline Attached; acidity juice per c.e............ & 1.01 & 0.42 & 1.20 & 0.98 & 0.44 \\
\hline
\end{tabular}

Serivg II. July 15, 16, 1912. Acidity of Jutce Only.

\begin{tabular}{|c|c|c|c|c|c|}
\hline & \multicolumn{5}{|c|}{$\begin{array}{l}\text { Time of determination and hours since } \\
\text { beginning of experiment. }\end{array}$} \\
\hline & $\begin{array}{l}1 \text { p.m., } \\
3 \text { hrs. }\end{array}$ & $\begin{array}{l}4 \text { p.m., } \\
6 \text { hrs. }\end{array}$ & $\begin{array}{l}10 \text { a.m., } \\
24 \text { hrs. }\end{array}$ & $\begin{array}{l}1 \text { p.m. } \\
27 \text { hrs. }\end{array}$ & $\begin{array}{l}4 \text { p.m., } \\
30 \mathrm{hrs} .\end{array}$ \\
\hline \multicolumn{6}{|l|}{$\begin{array}{l}\text { Young joints; initial acidity rer c.c. juice, } 1.71 . \\
\text { Experiment begun } 10 \text { a. m. }\end{array}$} \\
\hline Detached; acidity per c.c. juice............ & 0.92 & 0.40 & 1.70 & 0.88 & 0.33 \\
\hline Attached; acidity per e.c. juice.............. & 0.81 & 0.42 & 1.63 & 0.92 & 0.35 \\
\hline \multicolumn{6}{|l|}{$\begin{array}{l}\text { Young joints; initial acidity per c.c. juice, } 2.04 \text {. } \\
\text { Experiment begun } 10 \text { a. m. }\end{array}$} \\
\hline Detached; acidity per c.c. juice . . . . . . . . . . & 0.76 & 0.33 & 2.15 & 0.81 & 0.28 \\
\hline 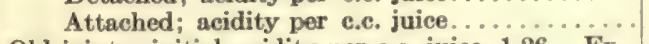 & 0.80 & 0.31 & 2.10 & 0.75 & 0.30 \\
\hline \multicolumn{6}{|l|}{$\begin{array}{l}\text { Old joints; initial acidity per c.c. juice, } 1.26 \text {. Ex- } \\
\text { periment begun } 10 \text { a. } \mathrm{m} \text {. }\end{array}$} \\
\hline Detached; acidity per c.c. juice........... & 0.80 & 0.27 & 1.12 & 0.73 & 0.25 \\
\hline Attached; acidity per c.c. juice................ & 0.72 & 0.26 & 1.15 & 0.78 & 0.34 \\
\hline \multicolumn{6}{|l|}{ Old joints; initial acidity per c.c. juice, 1.04 . Ex- } \\
\hline Detached; acidity per c.c. juice........ & 0.64 & 0.34 & 1.24 & 0.75 & 0.34 \\
\hline Attached; acidity per e.c. juice........... & 0.66 & 0.33 & 1.20 & 0.81 & 0.27 \\
\hline
\end{tabular}




\section{TABLE 8.-Diurnal range of acidity of Opuntia versicolor.}

The diurnal range of acidity of Opuntia versicolor, taken at 2-hour intervals over a period of 26 hours, from 9 a. m., March 25, to 11 a. m., March 26, 1911, at Tueson, Arizona. The day was an average one for the season, with temperature range of about $12^{\circ} \mathrm{C}$., from $24.5^{\circ}$ at $4 \mathrm{p}$. m. on March 25 to $12.2^{\circ}$ at $8 \mathrm{a}$. m. on March 26. Except for a slight shower and some cloudiness until $11 \mathrm{a}$. $\mathrm{m}$. March 25 the sky was clear.

Three simultaneous series were run, the material being freshly collected for each determination. The acidity is expressed in terms of cubic centimeters $\mathrm{N} / 10$ alkali for the total acidity of a 50-gram sample. The acidity per gram fresh weight is also given.

\begin{tabular}{|c|c|c|c|c|c|c|c|c|c|}
\hline \multirow[b]{2}{*}{ Time. } & \multirow[b]{2}{*}{ Temp. } & \multicolumn{2}{|c|}{ I. } & \multicolumn{2}{|c|}{ II. } & \multicolumn{2}{|c|}{ III. } & \multicolumn{2}{|c|}{ Average. } \\
\hline & & $\begin{array}{l}\text { Total } \\
\text { acidity. }\end{array}$ & $\begin{array}{c}\text { Acidity } \\
\text { per } \\
\text { gram. }\end{array}$ & $\begin{array}{l}\text { Total } \\
\text { acidity. }\end{array}$ & $\begin{array}{l}\text { Acidity } \\
\text { per } \\
\text { gram. }\end{array}$ & $\begin{array}{c}\text { Total } \\
\text { acidity. }\end{array}$ & $\begin{array}{c}\text { Acidity } \\
\text { per } \\
\text { gram. }\end{array}$ & $\begin{array}{c}\text { Total } \\
\text { acidity. }\end{array}$ & $\begin{array}{c}\text { Acidity } \\
\text { per } \\
\text { gram. }\end{array}$ \\
\hline 9 a.m. & $\begin{array}{l}{ }^{\circ} \mathrm{C} . \\
15.5\end{array}$ & 25.60 & 0.51 & 48.65 & 0.97 & 30.55 & 0.61 & 34.95 & 0.70 \\
\hline 11 a.m. & 20.5 & 22.95 & .46 & 32.00 & .64 & 24.60 & .49 & 26.50 & .53 \\
\hline 1 p.m. & 21.1 & 18.70 & .37 & 31.10 & .62 & 22.45 & .45 & 24.10 & .48 \\
\hline 3 p.m. & 21.7 & 16.60 & .33 & 29.50 & .59 & 13.20 & .26 & 19.75 & .39 \\
\hline 5 p.m. & 23.3 & 16.60 & .33 & 16.85 & .33 & 12.35 & .25 & 15.30 & .31 \\
\hline 7 p.m. & 21.7 & 20.60 & .41 & 19.55 & .39 & 17.50 & .35 & 19.20 & .38 \\
\hline 9 p.m. & 20.0 & 19.80 & .39 & 22.15 & .44 & 17.15 & .34 & 19.70 & .39 \\
\hline 11 p.m. & 18.9 & 23.50 & .47 & 25.80 & .52 & 21.20 & .42 & 23.50 & .47 \\
\hline 1 a.m. & 17.2 & 21.10 & .42 & 25.90 & .52 & 24.10 & .48 & 23.70 & .47 \\
\hline 3 a.m. & 15.5 & 26.90 & .54 & 31.05 & .62 & 24.10 & .48 & 27.35 & .56 \\
\hline 5 a.m. & 13.9 & 30.65 & .61 & 35.10 & .70 & 24.55 & .49 & 30.10 & .60 \\
\hline 7 a.m. & 12.8 & 34.00 & .68 & 35.20 & .70 & 26.35 & .53 & 31.85 & .64 \\
\hline 9 a.m. & 15.5 & 26.45 & .53 & 38.25 & .76 & 26.20 & .52 & 30.30 & .61 \\
\hline 11 a.m. & 20.5 & 23.20 & .46 & 31.90 & .64 & 25.05 & .50 & 26.70 & .53 \\
\hline
\end{tabular}

TABLE 9.-Diurnal periodicity of acidity, in comparison with temperature within the plant and also external temperature, Opuntia versicolor.

On April 1 the external temperature was maximum at 1 p. m. $30.8^{\circ}$ C. and minimum at 6 a. $\mathrm{m} .14 .4^{\circ} \mathrm{C}$. The temperature within the cactus joint was maximum at 12 noon, $38.3^{\circ}$ C., and minimum at 5 a. m., $12.8^{\circ} \mathrm{C}$. All of the determinations were made with material fresh from the plant and were from mature turgid joints. The acidity is given in terms of cubic centimeters of $\mathrm{N} / 10 \mathrm{KOH}$ for the whole sample of 50 grams fresh weight and also per gram.

\begin{tabular}{|c|c|c|c|c|c|c|c|c|c|}
\hline \multirow{3}{*}{ No. } & \multirow{3}{*}{ Time. } & \multirow{2}{*}{\multicolumn{2}{|c|}{ Temperature. }} & \multicolumn{6}{|c|}{ Acidity in cubic centimeter $\mathrm{N} / 10 \mathrm{KOH}$. } \\
\hline & & & & \multicolumn{2}{|c|}{ I. } & \multicolumn{2}{|c|}{ II. } & \multicolumn{2}{|c|}{ Average. } \\
\hline & & Air. & $\begin{array}{l}\text { Within } \\
\text { joint. }\end{array}$ & Total. & $\begin{array}{c}\text { Per } \\
\text { gram. }\end{array}$ & Total. & $\begin{array}{c}\text { Per } \\
\text { gram. }\end{array}$ & Total. & $\begin{array}{c}\text { Per } \\
\text { gram. }\end{array}$ \\
\hline 1 & $\begin{array}{r}\text { March 31, 1911: } \\
10^{\mathrm{h}} 30^{\mathrm{m}} \text { a.m. }\end{array}$ & $\begin{array}{l}{ }^{\circ} \mathrm{C} . \\
26.1\end{array}$ & ${ }^{\circ} \mathrm{C}$. & 21.85 & 0.44 & 32.15 & 0.64 & 27.00 & 0.54 \\
\hline 2 & 1 p.m..... & 29.6 & & 21.30 & .43 & $\begin{array}{l}32.10 \\
28.70\end{array}$ & $\begin{array}{r}0.04 \\
.57\end{array}$ & 25.00 & $\begin{array}{r}0.04 \\
.50\end{array}$ \\
\hline 3 & 4 p.m. & 32.2 & 32.8 & 16.50 & .33 & 21.20 & .42 & 18.85 & .38 \\
\hline 4 & 6 p.m..... & 31.1 & 25.5 & 16.50 & .33 & 18.75 & .38 & 17.60 & .35 \\
\hline 5 & $8^{\mathrm{h}} 30^{\mathrm{m}}$ p.m. & 25.0 & 21.6 & 25.70 & .51 & 29.10 & .58 & 27.40 & .55 \\
\hline 6 & $\begin{array}{r}11 \text { p.m.... } \\
\text { April 1, 1911: }\end{array}$ & 21.6 & 18.9 & 29.10 & .58 & 33.00 & .66 & 31.05 & .62 \\
\hline 7 & 2 a.m..... & 20.0 & 15.8 & 32.60 & .65 & 35.30 & .71 & 33.95 & .68 \\
\hline 8 & 5 a.m... & 17.2 & 12.8 & 37.45 & .75 & 38.80 & .78 & 38.10 & .76 \\
\hline 9 & 8 a.m... & 20.0 & 23.9 & 33.85 & .68 & 35.20 & .70 & 34.50 & .69 \\
\hline 10 & 11 p.m... & 27.8 & 31.1 & 22.15 & .44 & 30.50 & .61 & 26.30 & .53 \\
\hline 11 & 1 p.m.... & 30.8 & 35.0 & 18.10 & .36 & 20.00 & .40 & 19.05 & .38 \\
\hline 12 & 3 p.m... & 28.0 & 27.8 & 17.40 & .33 & 16.00 & .32 & 16.70 & .33 \\
\hline 13 & 5 p.m.... & 25.0 & 23.3 & 16.00 & .32 & 14.90 & .29 & 15.45 & .31 \\
\hline 14 & 6 p.m.... & 23.3 & & 19.20 & .38 & 20.15 & .40 & 19.70 & .39 \\
\hline
\end{tabular}




\section{TABLE 10.-Diurnal range of acidity in turgid joints of previous season's growth, Opuntia versicolor.}

Acidity was taken at 2 -hour intervals over a period of 26 hours. Two series were run, at Tucson, April 11, 12, 1911, the material having all been collected at the same time and exposed to the light and air. The day was clear and bright throughout, with a maximum of $28.5^{\circ}$ C. at $3^{\mathrm{h}} 30^{\mathrm{m}} \mathrm{p}$. m. on April 11 and a minimum of $15.5^{\circ}$ C. at $5^{\mathrm{h}} 30^{\mathrm{m}} \mathrm{a}$. m. on April 12 . The acidity is given in terms of $\mathrm{N} / 10$ alkali per gram fresh weight and pure juice, per cubic centimeter.

\begin{tabular}{|c|c|c|c|c|c|c|c|}
\hline \multirow[b]{2}{*}{ Date and time. } & \multirow[b]{2}{*}{ Temp. } & \multicolumn{2}{|c|}{ I. } & \multicolumn{2}{|c|}{ II. } & \multicolumn{2}{|c|}{ Average. } \\
\hline & & $\begin{array}{l}\text { Total } \\
\text { acidity } \\
\text { per gm., } \\
\text { fresh. }\end{array}$ & $\begin{array}{l}\text { Acidity } \\
1 \text { c.c., } \\
\text { juice. }\end{array}$ & $\begin{array}{c}\text { Total } \\
\text { acidity } \\
\text { per gm., } \\
\text { fresh. }\end{array}$ & $\begin{array}{l}\text { Acidity, } \\
1 \text { c.c., } \\
\text { juice. }\end{array}$ & $\begin{array}{c}\text { Total } \\
\text { acidity } \\
\text { per gm., } \\
\text { fresh. }\end{array}$ & $\begin{array}{l}\text { Acidity, } \\
1 \text { c.c., } \\
\text { juice. }\end{array}$ \\
\hline April 11: & ${ }^{\circ} \mathrm{C}$. & & & & & & \\
\hline $\begin{array}{r}9 \text { a.m. } \\
11 \text { a.m. }\end{array}$ & $\begin{array}{l}18.5 \\
26\end{array}$ & $\begin{array}{l}1.65 \\
1.40\end{array}$ & $\begin{array}{l}2.17 \\
1.92\end{array}$ & $\begin{array}{l}1.32 \\
1.16\end{array}$ & $\begin{array}{l}1.81 \\
1.62\end{array}$ & $\begin{array}{l}1.48 \\
1.28\end{array}$ & $\begin{array}{l}1.98 \\
1.77\end{array}$ \\
\hline 1 p.m. . & 28 & 1.05 & 1.45 & 0.95 & 1.23 & 1.00 & 1.34 \\
\hline 3 p.m.. & 29 & 0.67 & 0.95 & 0.58 & 0.90 & 0.62 & 0.93 \\
\hline 5 p.m. & 27.5 & 0.58 & 0.68 & 0.37 & 0.55 & 0.48 & 0.62 \\
\hline 8 p.m. & 24.5 & 0.79 & 1.10 & 0.54 & 0.92 & 0.67 & 1.01 \\
\hline 11 p.m. & 22 & 1.02 & 1.25 & 0.71 & 0.96 & 0.87 & 1.10 \\
\hline April 12: & & & & & & & \\
\hline 1 a.m. & 20 & 1.19 & 1.37 & 0.91 & 1.15 & 1.05 & 1.26 \\
\hline 3 a.m... & 18.5 & 1.32 & 1.58 & 1.04 & 1.22 & 1.18 & 1.40 \\
\hline 5 a.m.... & 16 & 1.48 & 1.75 & 1.19 & 1.28 & 1.34 & 1.52 \\
\hline 7 a.m. . & 19 & 1.68 & 2.15 & 1.28 & 1.62 & 1.48 & 1.89 \\
\hline 9 a.m. & 22.5 & 1.51 & 1.86 & 1.16 & 1.31 & 1.34 & 1.59 \\
\hline 11 a.m... & 25 & 1.39 & 1.81 & 1.02 & 1.28 & 1.20 & 1.55 \\
\hline
\end{tabular}

TABLE 11.-Diurnal periodicity of turgid joints at least 1 year old from irrigated plant of Opuntia versicolor.

The material had been collected 24 hours before use and had been placed in the dark constant-temperature room at a temperature of $23^{\circ} \mathrm{C}$, to accumulate as high an acidity as possible. The acidity is expressed in terms of $\mathrm{N} / 10$ alkali per cubic centimeter of pure, freshly extracted juice. After the first determination at $5^{\mathrm{h}} 30^{\mathrm{m}} \mathrm{a} . \mathrm{m}$. the joints were placed in full sunlight under as natural conditions as possible. The three series were made from different plants, at Tucson, July 27, 1913.

\begin{tabular}{|c|c|c|c|c|c|}
\hline \multirow{2}{*}{ Time. } & \multirow{2}{*}{ Temp. } & \multicolumn{4}{|c|}{$\begin{array}{l}\text { Acidity per cubic centimeter } \\
\text { pure juice. }\end{array}$} \\
\hline & & I. & II. & III. & Average. \\
\hline 5 a.m. . & ${ }_{20.5}^{\circ} C$ & 1.15 & 0.97 & 1.05 & 1.06 \\
\hline 6 a.m... & 20.8 & 1.09 & .95 & .98 & 1.01 \\
\hline 7 a.m... & 21.0 & 1.04 & .89 & .96 & .96 \\
\hline 8 a.m... & 22.2 & .99 & .89 & .93 & .94 \\
\hline 9 a.m... & 25.5 & .89 & .84 & .91 & .88 \\
\hline 10 a.m.. & 28.6 & .71 & .77 & .89 & .79 \\
\hline 11 a.m... & 31.1 & .62 & .62 & .75 & .66 \\
\hline 12 noon... & 32.2 & .52 & .49 & .70 & .57 \\
\hline 1 p.m.... & 33.9 & .46 & .43 & .56 & .48 \\
\hline 2 p.m... & 34.4 & .40 & .31 & .48 & .40 \\
\hline 3 p.m... & 33.9 & .33 & .20 & .39 & .31 \\
\hline 4 p.m... & 34.2 & .26 & .18 & .28 & .24 \\
\hline 5 p.m.. & 33.9 & .18 & .14 & .20 & .17 \\
\hline 6 p.m... & 33.3 & .14 & .17 & .20 & .17 \\
\hline 9 p.m... & 28.9 & .31 & .28 & .34 & .31 \\
\hline
\end{tabular}


TABLE 12.-Diurnal periodicity of acidity of mature-turgid and mature-flaccid and young joints with leaves of Opuntia versicolor.

All material was direct from the plant at time of determination. In each group of three the same plant was used. The morning determinations were taken between 9 and 10 o'clock; the afternoon determinations between 4 and 5 o'clock. Tucson, Arizona, July 29 to $31,1912$.

\begin{tabular}{|c|c|c|c|c|c|}
\hline \multirow{2}{*}{$\begin{array}{l}\text { Age of material and } \\
\text { time of day. }\end{array}$} & \multirow{2}{*}{$\begin{array}{l}\text { Fresh } \\
\text { weight, } \\
\text { grams. }\end{array}$} & \multirow{2}{*}{$\begin{array}{l}\text { Dry } \\
\text { weight, } \\
\text { grams. }\end{array}$} & \multicolumn{3}{|c|}{$\begin{array}{l}\text { Acidity in terms of cubic } \\
\text { centimeters } \mathrm{N} / 10 \mathrm{KOH} \text {. }\end{array}$} \\
\hline & & & $\begin{array}{l}\text { Per c.c. } \\
\text { juice. }\end{array}$ & $\begin{array}{l}\text { Per gram } \\
\text { fresh } \\
\text { weight. }\end{array}$ & $\begin{array}{c}\text { Per gram } \\
\text { dry } \\
\text { weight. }\end{array}$ \\
\hline $\begin{array}{l}\text { Young: } \\
\quad \text { Morning........ } \\
\text { Afternoon...... } \\
\text { Morning..... }\end{array}$ & $\begin{array}{l}50 \\
50 \\
50\end{array}$ & $\begin{array}{l}7.80 \\
7.50 \\
8.15\end{array}$ & $\begin{array}{l}1.50 \\
0.48 \\
1.35\end{array}$ & $\begin{array}{l}0.72 \\
0.15 \\
0.66\end{array}$ & $\begin{array}{l}4.62 \\
1.00 \\
4.10\end{array}$ \\
\hline $\begin{array}{l}\text { Morning......... } \\
\text { Afternoon ...... } \\
\text { Morning.... }\end{array}$ & $\begin{array}{l}50 \\
50 \\
20\end{array}$ & $\begin{array}{l}7.60 \\
8.00 \\
2.95\end{array}$ & $\begin{array}{l}0.90 \\
0.38 \\
0.70\end{array}$ & $\begin{array}{l}0.55 \\
0.17 \\
0.49\end{array}$ & $\begin{array}{l}3.62 \\
1.03 \\
3.32\end{array}$ \\
\hline $\begin{array}{l}\text { Morning........ } \\
\text { Afternoon...... } \\
\text { Morning..... }\end{array}$ & $\begin{array}{l}50 \\
50 \\
50\end{array}$ & $\begin{array}{l}8.10 \\
7.80 \\
8.25\end{array}$ & $\begin{array}{l}1.05 \\
0.28 \\
0.90\end{array}$ & $\begin{array}{l}0.63 \\
0.13 \\
0.60\end{array}$ & $\begin{array}{l}3.89 \\
0.83 \\
3.63\end{array}$ \\
\hline $\begin{array}{l}\text { Morning......... } \\
\text { Afternoon ......... } \\
\text { Morning..... }\end{array}$ & $\begin{array}{l}50 \\
50 \\
50\end{array}$ & $\begin{array}{l}7.70 \\
7.95 \\
7.45\end{array}$ & $\begin{array}{l}1.25 \\
0.45 \\
1.35\end{array}$ & $\begin{array}{l}0.78 \\
0.21 \\
0.70\end{array}$ & $\begin{array}{l}5.03 \\
1.16 \\
4.70\end{array}$ \\
\hline $\begin{array}{l}\text { Morning.......... } \\
\text { Afternoon........ } \\
\text { Morning..... }\end{array}$ & $\begin{array}{r}50 \\
100 \\
35\end{array}$ & $\begin{array}{r}8.00 \\
15.95 \\
5.55\end{array}$ & $\begin{array}{l}1.20 \\
0.38 \\
1.12\end{array}$ & $\begin{array}{l}0.82 \\
0.18 \\
0.75\end{array}$ & $\begin{array}{l}4.97 \\
1.15 \\
4.71\end{array}$ \\
\hline $\begin{array}{l}\text { Mature-turgid: } \\
\quad \text { Morning.......... } \\
\text { Afternoon....... } \\
\text { Morning....... }\end{array}$ & $\begin{array}{r}100 \\
100 \\
50\end{array}$ & $\begin{array}{r}20.45 \\
19.80 \\
9.65\end{array}$ & $\begin{array}{l}0.60 \\
0.36 \\
0.51\end{array}$ & $\begin{array}{l}0.28 \\
0.11 \\
0.29\end{array}$ & $\begin{array}{l}1.37 \\
0.91 \\
1.52\end{array}$ \\
\hline 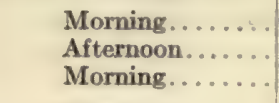 & $\begin{array}{l}50 \\
50 \\
50\end{array}$ & $\begin{array}{r}10.15 \\
9.85 \\
9.70\end{array}$ & $\begin{array}{l}0.71 \\
0.22 \\
0.66\end{array}$ & $\begin{array}{l}0.34 \\
0.09 \\
0.31\end{array}$ & $\begin{array}{l}1.38 \\
0.44 \\
1.55\end{array}$ \\
\hline $\begin{array}{l}\text { Morning......... } \\
\text { Afternoon....... } \\
\text { Morning...... }\end{array}$ & $\begin{array}{l}50 \\
\mathbf{5 0} \\
50\end{array}$ & $\begin{array}{r}9.70 \\
10.25 \\
9.95\end{array}$ & $\begin{array}{l}1.18 \\
0.41 \\
1.20\end{array}$ & $\begin{array}{l}0.90 \\
0.15 \\
1.04\end{array}$ & $\begin{array}{l}4.64 \\
0.73 \\
5.21\end{array}$ \\
\hline $\begin{array}{l}\text { Morning......... } \\
\text { Afternoon........ } \\
\text { Morning..... }\end{array}$ & $\begin{array}{l}50 \\
50 \\
50\end{array}$ & $\begin{array}{r}9.30 \\
9.80 \\
10.10\end{array}$ & $\begin{array}{l}1.24 \\
0.26 \\
1.05\end{array}$ & $\begin{array}{l}0.97 \\
0.17 \\
1.02\end{array}$ & $\begin{array}{l}5.19 \\
0.87 \\
5.02\end{array}$ \\
\hline $\begin{array}{l}\text { Morning......... } \\
\text { Afternoon ........ } \\
\text { Morning...... }\end{array}$ & $\begin{array}{l}50 \\
50 \\
50\end{array}$ & $\begin{array}{r}10.10 \\
9.60 \\
10.05\end{array}$ & $\begin{array}{l}0.95 \\
0.27 \\
0.92\end{array}$ & $\begin{array}{l}0.46 \\
0.10 \\
0.45\end{array}$ & $\begin{array}{l}2.28 \\
0.52 \\
2.25\end{array}$ \\
\hline $\begin{array}{l}\text { Mature-flaccid: } \\
\quad \text { Morning......... } \\
\text { Afternoon....... } \\
\text { Morning...... }\end{array}$ & $\begin{array}{l}50 \\
50 \\
50\end{array}$ & $\begin{array}{l}14.10 \\
13.80 \\
13.60\end{array}$ & $\begin{array}{l}1.15 \\
0.21 \\
0.98\end{array}$ & $\begin{array}{l}0.27 \\
0.16 \\
0.29\end{array}$ & $\begin{array}{l}0.96 \\
0.52 \\
1.06\end{array}$ \\
\hline $\begin{array}{l}\text { Morning.......... } \\
\text { Afternoon...... } \\
\text { Morning..... }\end{array}$ & $\begin{array}{l}50 \\
50 \\
50\end{array}$ & $\begin{array}{l}13.50 \\
14.05 \\
14.15\end{array}$ & $\begin{array}{l}0.96 \\
0.18 \\
0.98\end{array}$ & $\begin{array}{l}0.22 \\
0.08 \\
0.20\end{array}$ & $\begin{array}{l}0.82 \\
0.28 \\
0.71\end{array}$ \\
\hline
\end{tabular}




\section{TABLE 13.-Diurnal periodicily of acidity of young, turgid, newly formed joints from irrigated plants of Opuntia versicolor.}

The joints all showed some leaf development. The material was treated exactly as in the series shown in Table 11 with mature joints. The acidity is given also in the same terms. At Tucson, July 29, 1913.

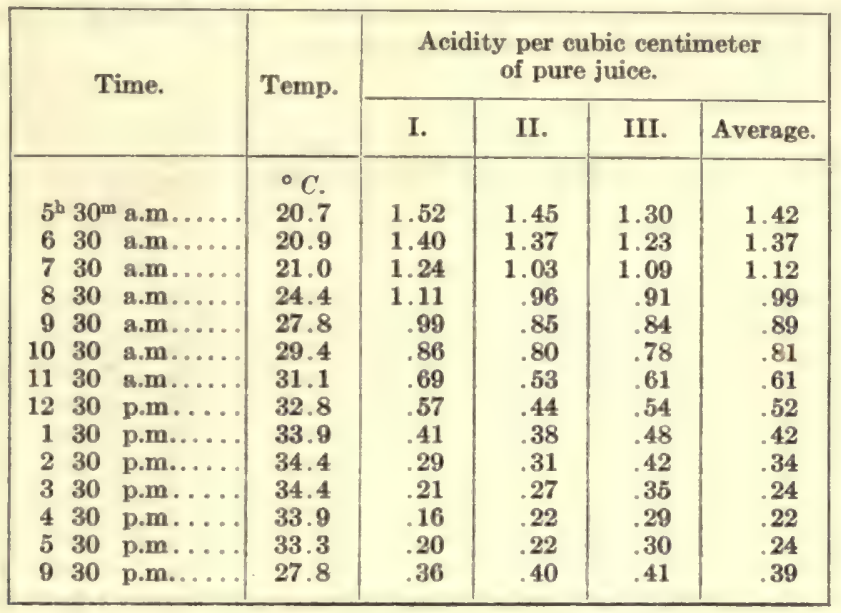

TABLE 14.-Effect of direct sunlight upon acidity. Opuntia versicolor.

The material used included both young and old turgid joints and was collected when the acidity was relatively high. The experiments were set up at once on the collection of the specimens. By immersion of the ventilated glass container under ice-water the temperature was kept low and fairly constant. For comparison the acidity of control duplicate materia] exposed in the open air until about $4 \mathrm{p} . \mathrm{m}$. is also given. The acidity is expressed in terms of centimeters $\mathrm{N} / 10$ alkali per cubic centimeter pure juice. The first set of observations, taken between August 1 and 4,1912, shows the effect of the increased intensity of the sunlight at that period of the year. The days were brilliantly elear and in each case showed a rise of about $10^{\circ} \mathrm{C}$, from $32^{\circ}$ at 10 a.m. to $42^{\circ}$ at $4 \mathrm{p} . \mathrm{m}$. The second set of observations was taken in March and April 1911; days clear, temperature $26^{\circ}$ at 10 a. m. to $32^{\circ}$ at $4 \mathrm{p} . \mathrm{m}$. All the observations were made at Tucson.

\begin{tabular}{|c|c|c|c|c|c|c|c|}
\hline Begun. & Ended. & $\begin{array}{l}\text { Dura- } \\
\text { tion. }\end{array}$ & $\begin{array}{c}\text { Age of } \\
\text { material. }\end{array}$ & $\begin{array}{l}\text { Original } \\
\text { acidity. }\end{array}$ & $\begin{array}{l}\text { Final } \\
\text { acid- } \\
\text { ity. }\end{array}$ & $\begin{array}{c}\text { Tempera- } \\
\text { ture at } \\
\text { which } \\
\text { exposed. }\end{array}$ & $\begin{array}{l}\text { Acidity } \\
\text { control } \\
\text { in open. }\end{array}$ \\
\hline Series I. & & hrs. & & & & ${ }^{\circ} \mathrm{C}$ & \\
\hline Aug. 2, 10 a.m... & Aug. $2,4^{\mathrm{h}} 30^{\mathrm{m}}$ p.m. & $6 \frac{1}{3}$ & Young. & 1.21 & 0.71 & 14 to 16 & 0.18 \\
\hline Do........ & $\ldots$ do.......... & $6 \frac{1}{2}$ & Young. & 1.21 & 0.79 & 5 to 6 & 0.18 \\
\hline Aug. $3,9^{\mathrm{h}} 30^{\mathrm{m}}$ a.m. & Aug. $3,4^{h} 15^{m}$ p.m. & $6 \frac{3}{3}$ & Young. & 1.48 & 0.61 & 20 & 0.21 \\
\hline Do......... & .... do........... & $6 \frac{3}{4}$ & Young. & 1.82 & 0.78 & 20 & 0.21 \\
\hline Aug. $3,9^{\mathrm{h}} 45^{\mathrm{m}}$ a.m & Aug. 4, 4 p.m. .... & $6 \frac{1}{4}$ & Young. & 1.78 & 0.64 & 18 to 20 & 0.30 \\
\hline Aug. 1,10 a.m... & Aug. 1, 4 p.m.... & 6 & Old.... & 1.21 & 0.64 & 12 to 16 & 0.20 \\
\hline Aug. $3,9^{\mathrm{h}} 30^{\mathrm{m}}$ a.m. & Aug. $3,4^{\mathrm{h}} 15^{\mathrm{m}}$ p.m. & $6 \frac{3}{4}$ & old.... & 1.12 & 0.53 & 20 & 0.18 \\
\hline Do.......... & .... do........... & $6 \frac{3}{4}$ & Old. & 1.04 & 0.62 & 20 & 0.20 \\
\hline Aug. $3,9^{\mathrm{h}} 30^{\mathrm{m}}$ a.m. & Aug. $4,3^{\mathrm{h}} 45^{\mathrm{m}}$ p.m. & $6 \frac{1}{4}$ & Old. & 1. 15 & 0.48 & 18 to 20 & 0.22 \\
\hline Serieg II. & & & & & & & 0.53 \\
\hline Mar. 30,10 a.m. . & Mar. 30,4 p.m. . . . & $\begin{array}{l}6 \\
6 \frac{1}{2}\end{array}$ & Old $\ldots$. & $\begin{array}{l}1.54 \\
1.04\end{array}$ & $\begin{array}{l}0.82 \\
0.91\end{array}$ & $\begin{array}{l}15 \text { to } 20 \\
15 \text { to } 20\end{array}$ & $\begin{array}{l}0.03 \\
0.45\end{array}$ \\
\hline $\begin{array}{l}\text { Mar. 31, } 10 \text { a.m. . } \\
\text { Apr. } 19,10 \text { a.m... }\end{array}$ & $\begin{array}{l}\text { Mar. } 31,4^{\mathrm{h}} 30^{\mathrm{m}} \text { p.m } \\
\text { Apr. } 19,5 \text { p.m. . . }\end{array}$ & $7^{2}$ & old.... & 1.78 & 1. 22 & 19 to 20 & 0.89 \\
\hline Do........... & ....do.............. & 7 & Old.... & 1.31 & 0.88 & 19 to 20 & 0.89 \\
\hline
\end{tabular}


TABLE 15.-Effect of increased temperatures on acidity. Opuntia versicolor.

The material used included both young and old turgid joints and in one ease young fruit. It was collected either in the morning, when the acidity was relatively high, or in the afternoon, when it was low, to test the effect on both the decrease and the increase of acidity. The experiments were set up at Tucson in July and August 1912 as soon as possible after gathering the material and were carried on in darkness. The acidity is expressed in terms of cubic centimeters $\mathrm{N} / \mathbf{1 0}$ per cubic centimeter pure juice.

\begin{tabular}{|c|c|c|c|c|c|c|c|}
\hline \multirow{2}{*}{ Begun. } & \multirow{2}{*}{ Ended. } & \multirow{2}{*}{$\begin{array}{l}\text { Dura- } \\
\text { tion. }\end{array}$} & \multirow{2}{*}{$\begin{array}{c}\text { Age of } \\
\text { material. }\end{array}$} & \multirow{2}{*}{$\begin{array}{c}\text { Origi- } \\
\text { nal } \\
\text { acidity. }\end{array}$} & \multicolumn{3}{|c|}{ Acidity in ${ }^{\circ} \mathrm{C}$. } \\
\hline & & & & & $15-20^{\circ}$ & $\left|30-31^{\circ}\right|$ & $40-41^{\circ}$ \\
\hline July 29,10 a.x & July 29,4 p.m.... & $\begin{array}{c}H r 8 . \\
6\end{array}$ & Your & 1.12 & 1.51 & 1.02 & 0.72 \\
\hline July 31,4 p. & Aug. $1,10^{h} 30^{m}$ a.m. & $18 \frac{1}{2}$ & Young. & 0.35 & 1.85 & 2.00 & 0.79 \\
\hline Aug. 1, 10 a.m & Aug. 1, 5 p.m.... & 7 & Young. & 1.92 & 2.10 & 2.30 & 0.95 \\
\hline Aug. 1, 4 p.m. & Aug. $2,10^{\mathrm{h}} 30^{\mathrm{m}}$ a.m. & $18 \frac{1}{2}$ & Young. & 0.12 & 1.03 & 1.48 & 0.70 \\
\hline Aug. $2,10^{\mathrm{h}} 15^{\mathrm{m}}$ a.m. . & Aug. $3,4^{\mathrm{b}} 15^{\mathrm{m}}$ p.m. & 30 & Young. & 1.44 & 1.56 & 1.00 & 0.74 \\
\hline Do........... & & 30 & Young. & 1.85 & 1.60 & & 0.81 \\
\hline July 29,10 a.r & July 29,4 p.m... & 6 & old.... & 1.14 & 1.06 & 1.26 & 0.81 \\
\hline & & 6 & Old. . & 1.20 & 1.15 & & 0.85 \\
\hline July 31,4 & Aug. $1,10^{h} 3$ & $18 \frac{1}{2}$ & Old.. & 0.25 & 1.30 & 1.34 & 0.80 \\
\hline Aug. 1, 4 & Aug. $2,10^{\mathrm{h}} 30^{\mathrm{m}}$ a.m. & $18 \frac{1}{2}$ & Old.. & 0.26 & 1.00 & 0.98 & 0.49 \\
\hline Do.. & $\ldots$. do........... & $18 \frac{1}{2}$ & Old.. & 0.22 & 1.15 & 1.30 & 0.56 \\
\hline Aug. $2,10^{\mathrm{h}} 15^{\mathrm{m}}$ g.m. & Aug. $3,4^{h} 15^{m}$ p.m. & 30 & Old.. & 1.36 & 1.04 & 0.88 & 0.68 \\
\hline Do......... & ....do............. & 30 & Old...... & 1.56 & 1.50 & 1.62 & 0.71 \\
\hline July 31,4 p.m. & Aug. $1,10^{h} 30^{\mathrm{m}}$ a.m. & $18 \frac{1}{2}$ & Fruit... & 0.21 & 1.20 & 1.21 & 0.57 \\
\hline
\end{tabular}

TABLE 16.-Accumulation of acid at various temperatures. Opuntia versicolor.

To show the effect of sustained exposure to various temperatures of material of relatively low acidity. The figures given are in each case the averages of two parallel determinations. The separate lots of material were kept in the dark at the temperatures given, which maintained a fair degree of constancy. The total acidity refers to that of a 50-gram sample and is expressed in cubic centimeters of $\mathrm{N} / 10$ alkali.

\section{SERTES I.}

[Material collected at $3^{\text {h }} 30^{m}$ p.m., March 28, 1911. Series begun at 4 p.m. Acidity at beginning: Total, 31.20; per gram, 0.60.]

\begin{tabular}{|c|c|c|c|c|c|c|c|c|}
\hline \multirow{2}{*}{ Temp. } & \multicolumn{2}{|c|}{$\begin{array}{c}\text { Mar. 29, 1911, } \\
10 \text { a.m., } 18 \text { hours. }\end{array}$} & \multicolumn{2}{|c|}{$\begin{array}{l}\text { Mar. 29, 1911, } \\
4 \text { p.m., } 24 \text { hours. }\end{array}$} & \multicolumn{2}{|c|}{$\begin{array}{l}\text { Mar. 30, 1911, } \\
3 \text { p.m., } 47 \text { hours. }\end{array}$} & \multicolumn{2}{|c|}{$\begin{array}{l}\text { Mar. 31, 1911, } \\
1 \text { p.m., } 69 \text { hours. }\end{array}$} \\
\hline & $\begin{array}{l}\text { Total } \\
\text { acidity. }\end{array}$ & $\begin{array}{c}\text { Acidity } \\
\text { per gram. }\end{array}$ & $\begin{array}{l}\text { Total } \\
\text { acidity. }\end{array}$ & $\begin{array}{c}\text { Acidity } \\
\text { per gram. }\end{array}$ & $\begin{array}{l}\text { Total } \\
\text { acidity. }\end{array}$ & $\begin{array}{l}\text { Acidity } \\
\text { per gram. }\end{array}$ & $\begin{array}{l}\text { Total } \\
\text { acidity. }\end{array}$ & $\begin{array}{c}\text { Acidity } \\
\text { per gram }\end{array}$ \\
\hline${ }^{\circ} \mathrm{C}$. & & & & & & & & \\
\hline 7 & 29.60 & 0.57 & 40.20 & 0.80 & 39.75 & 0.40 & 65.40 & 1.31 \\
\hline 10 & 31.70 & .63 & 33.00 & .66 & 48.30 & .97 & 62.05 & 1.24 \\
\hline 18 & 41.50 & .83 & 43.35 & .86 & 51.95 & 1.0 & 55.85 & 1.12 \\
\hline 20 & 58.00 & 1.16 & 47.65 & .95 & 51.50 & 1.03 & 47.20 & .94 \\
\hline 31 & 38.00 & .76 & 37.25 & .74 & & .90 & 42.55 & .85 \\
\hline 46 & 25.55 & .51 & 30.30 & .61 & 17.70 & .37 & 15.10 & .30 \\
\hline
\end{tabular}


TABLE 16-Continued.

SERIEs II.

[Mate rial collected at $2^{\mathrm{b}} 30^{\mathrm{m}}$ p.m., April 10, 1911. Series begun at 3 p.m. Acidity at beginning: Total 30.50; per gram, 0.65.]

\begin{tabular}{|c|c|c|c|c|c|c|c|c|c|c|}
\hline \multirow{2}{*}{ Temp. } & \multicolumn{2}{|c|}{$\begin{array}{c}\text { Apr. 1, 1911, } \\
9 \text { a.m., 18 } \\
\text { hours. }\end{array}$} & \multicolumn{2}{|c|}{$\begin{array}{c}\text { Apr. } 2,1911, \\
3 \text { p.m., } 24 \\
\text { hours. }\end{array}$} & \multicolumn{2}{|c|}{$\begin{array}{l}\text { Apr. } 3,1911, \\
3 \text { p.m., } 48 \\
\text { hours. }\end{array}$} & \multicolumn{2}{|c|}{$\begin{array}{l}\text { Apr. } 4,1911, \\
3 \text { p.m., } 72 \\
\text { hours. }\end{array}$} & \multicolumn{2}{|c|}{$\begin{array}{l}\text { Apr. } 5,1911 \\
3 \text { p.m., } 96 \\
\text { hours. }\end{array}$} \\
\hline & $\begin{array}{l}\text { Total } \\
\text { acidity }\end{array}$ & $\begin{array}{l}\text { Acidity } \\
\text { per } \\
\text { gram. }\end{array}$ & $\begin{array}{l}\text { Total } \\
\text { acidity. }\end{array}$ & $\begin{array}{l}\text { Acidity } \\
\text { per } \\
\text { gram. }\end{array}$ & $\begin{array}{l}\text { Total } \\
\text { acidity }\end{array}$ & $\begin{array}{c}\text { Acidity } \\
\text { per } \\
\text { gram. }\end{array}$ & $\begin{array}{l}\text { Total } \\
\text { acidity }\end{array}$ & $\begin{array}{c}\text { Acidity } \\
\text { per } \\
\text { gram. }\end{array}$ & $\begin{array}{l}\text { Total } \\
\text { acidity. }\end{array}$ & $\begin{array}{c}\text { Acidity } \\
\text { per } \\
\text { gram. }\end{array}$ \\
\hline${ }^{\circ} \mathrm{C}$. & & & & & & & & & & \\
\hline 7 & 30.10 & 0.60 & 39.20 & 0.78 & 43.40 & 0.87 & 68.25 & 1.32 & 69.20 & 1.38 \\
\hline 10 & 33.00 & $\begin{array}{l}0.66 \\
0.79\end{array}$ & $\begin{array}{l}37.15 \\
41.10\end{array}$ & 0.74 & 43.20 & 0.8 & 60.00 & 1.2 & 58.4 & 1.17 \\
\hline 18 & 39.50 & $\begin{array}{l}0.79 \\
.722\end{array}$ & $\begin{array}{l}41.10 \\
53 .\end{array}$ & 0.8 & 52.40 & 1.0 & 57.0 & 1.1 & $\begin{array}{l}58.25 \\
41.00\end{array}$ & 1.16 \\
\hline 21 & 51.10 & 1.22 & 53.40 & 1.07 & 54.60 & 1.09 & 45.00 & 0.9 & 41.00 & 0.82 \\
\hline 31 & 40.70 & 0.81 & 42.00 & 0.84 & 41.80 & 0.84 & 36.70 & 0.73 & 33.90 & 0.68 \\
\hline 47 & & & 29.30 & 0.59 & 18.25 & 0.36 & 16.30 & 0.33 & 16.15 & 0.31 \\
\hline
\end{tabular}

TABLE 17.-Effect of diminished and increased oxygen supply. Opuntia versicolor.

The experiments were carried on in New York with material sent from Tucson. The joints were still turgid from the winter rains and had been kept where the water-loss was minimized. In Series I, both juice and total acidity are given; in Series II, only juice acidity. Acidity is given in terms of cubic centimeters of $\mathrm{N} / 10 \mathrm{KOH}$ per cubic centimeter of juice or per gram fresh weight.

Series I.

\begin{tabular}{|c|c|c|c|c|c|c|c|c|}
\hline \multirow{2}{*}{ Begun. } & \multirow{2}{*}{ Ended. } & \multirow{2}{*}{$\begin{array}{l}\text { Dura- } \\
\text { tion. }\end{array}$} & \multirow{2}{*}{ Age. } & \multirow{2}{*}{ Temp. } & \multicolumn{2}{|c|}{ Acidity in air. } & \multicolumn{2}{|c|}{$\begin{array}{l}\text { Acidity in } \mathrm{H}_{2} \\
\text { about } 97 \text { p. ct. }\end{array}$} \\
\hline & & & & & $\begin{array}{l}\text { Pure } \\
\text { juice. }\end{array}$ & $\begin{array}{c}\text { Total } \\
\text { acidity. }\end{array}$ & $\begin{array}{l}\text { Pure } \\
\text { juice. }\end{array}$ & $\begin{array}{c}\text { Total } \\
\text { acidity. }\end{array}$ \\
\hline $\begin{array}{r}\text { Apr. } 8,10 \text { a.m... } \\
\text { Apr. } 11,4 \text { p.m... } \\
\text { Do. } \ldots \ldots . . \\
\text { Apr. } 12,3 \text { p.m... } \\
\text { Do } \ldots . . . . \\
\text { Apr. } 14,4 \text { p.m... }\end{array}$ & $\begin{array}{l}\text { Apr. 10, } 10 \text { a.m... } \\
\text { Apr. 12, } 4 \text { p.m... } \\
\ldots \ldots \text { do.......... } \\
\text { Apr. 13, } 3 \text { p.m... } \\
\text { Apr. } 15,4 \text { do......... }\end{array}$ & $\begin{array}{c}\text { hrs. } \\
48 \\
24 \\
24 \\
24 \\
24 \\
24\end{array}$ & $\begin{array}{l}\text { Old. } \\
\text { Old. } \\
\text { Old. } \\
\text { Old. } \\
\text { Old. } \\
\text { Old. }\end{array}$ & $\begin{array}{c}{ }^{\circ} C \\
20 \\
20 \\
20 \\
20 \\
20 \\
20\end{array}$ & $\begin{array}{l}0.54 \\
0.89 \\
0.72 \\
0.96 \\
1.05 \\
0.97\end{array}$ & $\begin{array}{l}0.22 \\
0.45 \\
0.33 \\
0.48 \\
0.54 \\
0.45\end{array}$ & $\begin{array}{l}0.87 \\
0.91 \\
0.52 \\
0.98 \\
1.41 \\
1.22\end{array}$ & $\begin{array}{l}0.28 \\
0.48 \\
0.23 \\
0.54 \\
0.66 \\
0.57\end{array}$ \\
\hline
\end{tabular}

Srrmes II.

\begin{tabular}{|c|c|c|c|c|c|c|c|}
\hline Begun. & Ended. & $\begin{array}{l}\text { Dura- } \\
\text { tion. }\end{array}$ & Temp. & $\begin{array}{l}\text { Initial } \\
\text { acidity. }\end{array}$ & $\begin{array}{l}\text { Final } \\
\text { acidity } \\
\text { in air. }\end{array}$ & $\begin{array}{c}\text { Final } \\
\text { acidity } \\
\text { in } \mathbf{H}_{2} \text {. }\end{array}$ & $\begin{array}{l}\text { Final } \\
\text { acidity } \\
\text { in } \mathrm{O}_{2} \text {. }\end{array}$ \\
\hline 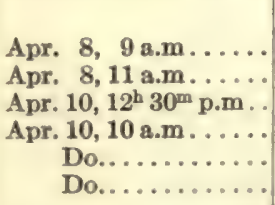 & $\begin{array}{l}\text { Apr. 9, } 10 \text { a.m. . } \\
\text { Apr. 9,11 a.m. . } \\
\text { Apr. 11, } 11 \text { a.m. . } \\
\text { Apr. 12, } 10 \text { a.m. . } \\
\text { Apr. 11, } 6 \text { p.m. } \\
\text { Apr. 12, } 10 \text { a.m. . }\end{array}$ & $\begin{array}{l}\text { Hrs. } \\
25 \\
24 \\
22 \frac{1}{2} \\
24 \\
32 \\
48\end{array}$ & \begin{tabular}{ll}
\multicolumn{2}{c}{${ }^{\circ} C}$. \\
\multicolumn{2}{c}{20} \\
\multicolumn{2}{c}{20} \\
21 to 23 \\
21 & 23 \\
21 & 23 \\
21 & 23
\end{tabular} & $\begin{array}{l}0.95 \\
0.90 \\
0.89 \\
1.48\end{array}$ & $\begin{array}{l}0.92 \\
1.05 \\
0.86 \\
1.10\end{array}$ & $\begin{array}{l}0.84 \\
1.31 \\
0.89 \\
1.15 \\
1.18 \\
1.29\end{array}$ & $\begin{array}{l}0.70 \\
0.81 \\
0.63 \\
0.86 \\
0.91 \\
0.57\end{array}$ \\
\hline
\end{tabular}


TABLE 18.-Acidity in diminished and increased oxygen supply of old and young joints of Opuntia versicolor.

Acidity is shown in terms of cubic centimeters of $\mathrm{N} / 10 \mathrm{KOH}$ per cubic centimeter juice. Experiments kept in darkness. Tucson, Arizona, July 1912.

\begin{tabular}{|c|c|c|c|c|c|c|c|c|}
\hline Begun. & Ended. & $\begin{array}{l}\text { Du- } \\
\text { ra- } \\
\text { tion. }\end{array}$ & Age. & Temp. & $\begin{array}{l}\text { Initial } \\
\text { acidity. }\end{array}$ & $\begin{array}{l}\text { Acidity } \\
\text { in air, } \\
\text { final. }\end{array}$ & $\begin{array}{c}\text { Acidity } \\
\text { in } \mathrm{H}_{2} \\
99+\text { p.ct. } \\
\text { final. }\end{array}$ & $\begin{array}{l}\text { Acidity } \\
\text { in } \mathrm{O}_{2} \\
75 \text { to } \\
80 \text { p.et., } \\
\text { final. }\end{array}$ \\
\hline July 20,4 p.m & July 21,2 p.m & 22 & Old $^{2}$. & $\begin{array}{c}{ }^{\circ} C . \\
30 \text { to } 32\end{array}$ & 1.10 & 0.42 & 0.94 & 0.27 \\
\hline Do..... & ....do........... & 22 & Old... & $30 \quad 32$ & 1.22 & 0.89 & 1.05 & 0.57 \\
\hline Do.. & July $21,4^{\mathrm{h}} 15^{\mathrm{m}}$ p. m. & $24\}$ & Old... & 30 & 1.32 & 0.99 & 1.21 & 0.65 \\
\hline Do..... & July 23,4 p.m.... & 72 & Old. & 30 & 1.15 & 0.80 & 0.84 & 0.66 \\
\hline July 23,10 a.m & July 24,4 p.m. . & 30 & Old $^{2}$. & 25 & 1.61 & 1.33 & 1.25 & 0.66 \\
\hline Do...... & $\ldots \ldots$ do............ & 30 & Old... & $25 \quad 32$ & 1.54 & 1.22 & 1.46 & 0.81 \\
\hline Do...... & ..... do.. & 30 & Young & 25 & 2.10 & 1.98 & 2.20 & 0.99 \\
\hline July 24,10 a.m & July 24 , noon..... & 26 & Young & 29 & 1.85 & 1.18 & 1.57 & 0.72 \\
\hline Do...... & $\ldots$. do........ & 26 & Young & 29 & 1.91 & 1.20 & 2.10 & 0.84 \\
\hline Do... & July 25,10 a.m... & 48 & Young & 30 & 1.66 & 1.12 & 1.62 & 0.42 \\
\hline
\end{tabular}

${ }^{1}$ Material for this and three subsequent experiments were collected several days before using. Kept in dark, relatively cool place.

${ }^{2}$ Material for this and all subsequent experiments were freshly collected.

TABLE 19.-Acidity in diminished and increased oxygen supply in Opuntia versicolor, material taken at time of low acidity.

Material was taken at time of low acidity to test the effect of the conditions upon possible rise of acidity. The experiments were kept in darkness. The series was carried through in July 1912 at Tucson. (For further details see table 18.)

\begin{tabular}{|c|c|c|c|c|c|c|c|c|}
\hline Begun. & Ended. & $\begin{array}{l}\text { Dura- } \\
\text { tion. }\end{array}$ & Age. & Temp. & $\begin{array}{c}\text { Origi- } \\
\text { nal } \\
\text { acidity. }\end{array}$ & $\begin{array}{l}\text { Acidity } \\
\text { in air } \\
\text { at end. }\end{array}$ & $\begin{array}{c}\text { Acidity } \\
\text { in } \mathbf{H}_{2} \\
98+ \\
\text { p. ct. }\end{array}$ & $\begin{array}{l}\text { Acidity } \\
\text { in } O_{3} \\
75 \text { to } \\
80 \text { p. ct. }\end{array}$ \\
\hline $\begin{array}{r}\text { July } 25,4 \text { p.m. } \\
\text { Do..... } \\
\text { Do..... } \\
\text { Aug. } 3,4 \text { p.m. } \\
\text { Do..... } \\
\text { Do..... }\end{array}$ & 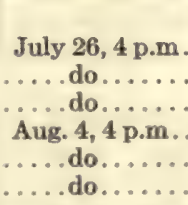 & $\begin{array}{l}h r 8 . \\
24 \\
24 \\
24 \\
24 \\
24 \\
24\end{array}$ & $\begin{array}{l}\text { Old..... } \\
\text { Old..... } \\
\text { Old...... } \\
\text { Young... } \\
\text { Young.. } \\
\text { Young.. }\end{array}$ & $\begin{array}{l}{ }^{\circ} C . \\
30 \\
30 \\
30 \\
30 \\
30 \\
30\end{array}$ & $\begin{array}{l}0.15 \\
0.28 \\
0.25 \\
0.64 \\
0.35 \\
0.44\end{array}$ & $\begin{array}{l}0.63 \\
0.94 \\
1.22 \\
1.41 \\
1.66 \\
1.89\end{array}$ & $\begin{array}{l}1.06 \\
1.12 \\
1.14 \\
1.32 \\
1.71 \\
1.68\end{array}$ & $\begin{array}{l}0.40 \\
0.31 \\
0.39 \\
0.49 \\
0.55 \\
0.34\end{array}$ \\
\hline
\end{tabular}

TABLE 20.-Acidity in diminished and increased oxygen supply, with material exposed to diffuse light during daytime.

The material (Opuntia versicolor) exposed to diffuse light during daytime. The experiments were made in July 1912 at Tucson. (For further particulars see preceding series.)

\begin{tabular}{|c|c|c|c|c|c|c|c|c|}
\hline Begun. & Ended. & $\begin{array}{l}\text { Dura- } \\
\text { tion. }\end{array}$ & Age. & Temp. & $\begin{array}{l}\text { Origi- } \\
\text { nal } \\
\text { acidity. }\end{array}$ & $\begin{array}{l}\text { Acidity } \\
\text { in air } \\
\text { at end. }\end{array}$ & $\begin{array}{c}\text { Acidity } \\
\text { in } \mathbf{H}_{2} \\
98+ \\
\text { p. et. }\end{array}$ & $\begin{array}{l}\text { Acidity } \\
\text { in } \mathrm{O}_{2} \\
75 \text { to } \\
80 \text { p. ct. }\end{array}$ \\
\hline $\begin{array}{r}\text { July } 23,10 \text { a.m } \\
\text { July } 25,2 \text { p.m } \\
\text { Do. } \ldots . . \\
\text { July } 25,10 \text { a.m. } \\
\text { Do. } \ldots . . \\
\text { July } 25,4 \text { p.m. }\end{array}$ & 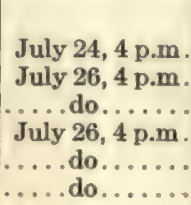 & $\begin{array}{r}\text { hrs. } \\
30 \\
26 \\
26 \\
30 \\
30 \\
24\end{array}$ & $\begin{array}{l}\text { Old... } \\
\text { Old... } \\
\text { Old... } \\
\text { Young } \\
\text { Young } \\
\text { Young }\end{array}$ & \begin{tabular}{ll}
\multicolumn{2}{c}{${ }^{\circ} C}$. \\
25 to 32 \\
23 & 30 \\
23 & 30 \\
25 & 32 \\
25 & 32 \\
25 & 32
\end{tabular} & $\begin{array}{l}1.61 \\
1.00 \\
1.15 \\
1.91 \\
1.91 \\
1.33\end{array}$ & $\begin{array}{l}0.99 \\
0.46 \\
0.35 \\
0.44 \\
0.44 \\
0.49\end{array}$ & $\begin{array}{l}1.25 \\
0.67 \\
0.96 \\
1.42 \\
1.30 \\
0.98\end{array}$ & $\begin{array}{l}0.65 \\
0.33 \\
0.21 \\
0.38 \\
0.41 \\
0.36\end{array}$ \\
\hline
\end{tabular}


TABLE 21.-Effect of injury on acidity. Opuntia versicolor.

Shows the effect of injury on acidity in mature joints, turgid from winter rains and injured by slicing into sections 5 to $10 \mathrm{~mm}$. thick, at Tucson, Arizona, March 1911. The sections were kept in moist atmosphere, but with free access of air, and in diffuse light at laboratory temperature $23^{\circ}$ to $25^{\circ} \mathrm{C}$. Acidity is expressed in terms of cubic centimeters of $\mathrm{N} / 10 \mathrm{KOH}$ per gram fresh weight.

\begin{tabular}{|r|c|c|c|c|c|c|}
\hline $\begin{array}{c}\text { Number of } \\
\text { experiment. }\end{array}$ & $\begin{array}{c}\text { Acidity } \\
\text { before } \\
\text { wounding. }\end{array}$ & $\begin{array}{c}24 \text { hours } \\
\text { after. }\end{array}$ & $\begin{array}{c}36 \text { hours } \\
\text { after. }\end{array}$ & $\begin{array}{c}48 \text { hours } \\
\text { after. }\end{array}$ & $\begin{array}{c}60 \text { hours } \\
\text { after. }\end{array}$ & $\begin{array}{c}72 \text { hours } \\
\text { after. }\end{array}$ \\
\hline $1 \ldots \ldots \ldots \ldots$ & 0.87 & 0.60 & 0.63 & 0.64 & 0.69 & 0.66 \\
$2 \ldots \ldots \ldots \ldots$ & 0.58 & 0.40 & 0.39 & 0.43 & 0.42 & 0.44 \\
$3 \ldots \ldots \ldots \ldots$ & 1.36 & 1.02 & 1.06 & 1.01 & 1.05 & 1.08 \\
$5 \ldots \ldots \ldots \ldots$ & 0.71 & 0.81 & 0.78 & 0.78 & 0.75 & 0.76 \\
Average... & 0.92 & 0.67 & 0.67 & 0.67 & 0.70 & 0.71 \\
\hline
\end{tabular}

TABLE 22.-Acidity of tissues of different ages. Opuntia versicolor.

Acidity is expressed in terms of cubic centimeters of $\mathrm{N} / 10 \mathrm{KOH}$ per gram fresh weight. The material was all mature and turgid from the winter rains. The temperature throughout the experiment was $23^{\circ}$ to $25^{\circ} \mathrm{C}$. The experiments were conducted at Tucson, Arizona, in March 1911.

\begin{tabular}{|c|c|c|c|c|c|c|c|c|c|}
\hline \multirow{2}{*}{$\begin{array}{c}\text { No. } \\
\text { of } \\
\text { expt. }\end{array}$} & \multirow{2}{*}{ Time of day. } & \multicolumn{2}{|c|}{ Shoot, 1 year old. } & \multicolumn{2}{|c|}{ Shoot, 2 years old. } & \multicolumn{2}{|c|}{$\begin{array}{c}\text { Shoot, } 3 \text { or more } \\
\text { years old. }\end{array}$} & \multicolumn{2}{|c|}{$\begin{array}{l}\text { Shoot, with } \\
\text { flower-buds. }\end{array}$} \\
\hline & & $\begin{array}{c}\text { Total } \\
\text { acidity. }\end{array}$ & $\begin{array}{l}\text { Acidity } \\
1 \text { c.c. } \\
\text { juice. }\end{array}$ & $\begin{array}{c}\text { Total } \\
\text { acidity. }\end{array}$ & $\begin{array}{c}\text { Acidity } \\
1 \text { c.c. } \\
\text { juice. }\end{array}$ & $\begin{array}{c}\text { Total } \\
\text { acidity. }\end{array}$ & $\begin{array}{c}\text { Acidity } \\
1 \text { c.c. } \\
\text { juice. }\end{array}$ & $\begin{array}{c}\text { Total } \\
\text { acidity. }\end{array}$ & $\begin{array}{c}\text { Acidity } \\
1 \text { c.c. } \\
\text { juice. }\end{array}$ \\
\hline \multirow{6}{*}{$\begin{array}{l}1 \\
2 \\
3 \\
4 \\
5\end{array}$} & Afternoon. . & 0.40 & 0.34 & 0.40 & 0.32 & 0.39 & 0.38 & 0.78 & 0.80 \\
\hline & Afternoon.. & 0.53 & 0.47 & 0.56 & 0.48 & 0.45 & 0.49 & $\ldots$ & $\ldots \ldots$ \\
\hline & Morning... & 0.99 & 1.10 & 0.93 & 1.08 & 0.94 & 1.06 & & \\
\hline & Morning... & 1.40 & 1.26 & 1.42 & 1.19 & 1.26 & 1.22 & 1.68 & 1.62 \\
\hline & Morning. . . & 1.36 & 1.15 & 1.25 & 1.17 & 1.24 & 1.10 & & $\ldots . .$. \\
\hline & Average.... & 0.94 & 0.86 & 0.91 & 0.85 & 0.86 & 0.85 & 1.23 & 1.21 \\
\hline
\end{tabular}

TABLE 23.-Diurnal periodicity of acidity in Mammillaria grahami.

Tucson, Arizona, March and April 1911. The acidity is given in cubic centimeters N/10 KOH per gram fresh weight. The plants being small, it was necessary to use a separate one for each determination.

\begin{tabular}{|c|c|c|c|c|}
\hline Time. & $\begin{array}{c}\text { I. } \\
\text { Mar. } 31 \text { to } \\
\text { Apr. 1, 1911. }\end{array}$ & $\begin{array}{c}\text { II. } \\
\text { Mar. 31 to } \\
\text { Apr. 1, } 1911 .\end{array}$ & $\begin{array}{l}\text { III. } \\
\text { Apr. 11-12, } \\
\text { 1911. }\end{array}$ & Average. \\
\hline 9 a.m. & 0.68 & 0.74 & 0.80 & 0.74 \\
\hline 11 a.m. & 0.46 & 0.60 & 0.62 & 0.53 \\
\hline 1 p.m. & 0.37 & 0.36 & 0.41 & 0.38 \\
\hline 4 p.m. & 0.17 & 0.19 & 0.22 & 0.19 \\
\hline 6 p.m. . & 0.24 & 0.22 & 0.35 & 0.27 \\
\hline 8 p.m. & 0.30 & 0.32 & 0.43 & 0.35 \\
\hline 11 p.m. & 0.43 & 0.46 & 0.58 & 0.49 \\
\hline 5 a.m. & 0.80 & 0.89 & 0.76 & 0.82 \\
\hline 8 a.m... & 0.81 & 0.94 & 0.85 & 0.87 \\
\hline 11 a.m. & 0.57 & 0.68 & 0.25 & 0.49 \\
\hline
\end{tabular}


TABLE 24.-Acidity of Opuntia leptocaulis, $O$. discata, and $O$. blakeana at various hours of the day.

The amount of acid is given in cubic centimeters of $\mathrm{N} / 10 \mathrm{KOH}$ per gram fresh weight. Owing to the large amount of glutinous substance expressed from the tissues of these species in extracting the juice, the determinations as made by the method employed can not be considered more than approximate; nevertheless they show the characteristic decrease in acidity as the day advances. The experiments were conducted at Tucson, Arizona, in March and April 1911.

\begin{tabular}{|c|c|c|c|}
\hline Species. & 9 a.m. & 12 noon. & 4 p.m. \\
\hline Opuntia leptocaulis... & $\begin{array}{l}2.20 \\
1.45 \\
1.90\end{array}$ & $\begin{array}{l}1.42 \\
0.79 \\
1.00\end{array}$ & $\begin{array}{l}0.81 \\
0.43 \\
0.66\end{array}$ \\
\hline Opuntia discata..... & $\begin{array}{l}1.60 \\
0.61 \\
0.74\end{array}$ & $\begin{array}{l}1.05 \\
0.48 \\
0.53\end{array}$ & $\begin{array}{l}0.65 \\
0.21 \\
0.20\end{array}$ \\
\hline Opuntia blakeana..... & 1.45 & 0.95 & 0.53 \\
\hline
\end{tabular}

TABLE 25.-Diurnal decrease in acidity in Carnegiea gigantea (Sahuaro).

The acidity is given in cubic centimeters $\mathrm{N} / 10 \mathrm{KOH}$ per gram fresh weight and per cubic centimeter pure juice. The material came from a single plant and was in every case from the cortical tissue. Care was taken that the different samples came from somewhat separated regions to avoid possible traumatic effects. This experiment was made at Tucson, Arizona, in April 1911.

\begin{tabular}{|c|c|c|c|c|c|c|}
\hline \multirow[b]{2}{*}{ Date. } & \multicolumn{2}{|c|}{9 a.m. } & \multicolumn{2}{|c|}{12 noon. } & \multicolumn{2}{|c|}{4 p.m. } \\
\hline & $\begin{array}{l}\text { Per gram } \\
\text { fresh } \\
\text { weight. }\end{array}$ & $\begin{array}{c}\text { Per c.c. } \\
\text { juice. }\end{array}$ & $\begin{array}{c}\text { Per gram } \\
\text { fresh } \\
\text { weight. }\end{array}$ & $\begin{array}{l}\text { Per e.c. } \\
\text { juice. }\end{array}$ & $\begin{array}{c}\text { Per gram } \\
\text { fresh } \\
\text { weight. }\end{array}$ & $\begin{array}{l}\text { Per c.c. } \\
\text { juice. }\end{array}$ \\
\hline Apr. 3,1911 & 0.77 & 0.91 & 0.63 & 0.76 & 0.41 & 0.58 \\
\hline Apr. 5,1911 & 0.69 & 0.89 & 0.56 & 0.69 & 0.38 & 0.46 \\
\hline Apr. 5,1911 & 0.76 & 0.94 & 0.60 & 0.75 & 0.41 & 0.51 \\
\hline Apr. 25,1911 & 0.62 & 0.81 & 0.54 & 0.70 & 0.39 & 0.49 \\
\hline Apr. 26, 1911 & 1.12 & 1.00 & 0.81 & 0.80 & 0.56 & 0.47 \\
\hline Average. & 0.79 & 0.91 & 0.63 & 0.74 & 0.43 & 0.50 \\
\hline
\end{tabular}




\title{
EVOLUTION OF CARBON DIOXIDE AS DETERMINED BY THE PETTENKOFER METHOD.
}

\author{
NORMAL RESPIRATION.
}

The rate of liberation of carbon dioxide in the cacti shows considerable variation, which is to be expected if it is in any way connected with the acidity and the fluctuations thereof. In the first place, there must be distinguished here, as in the case of acidity, three classes of tissue. These are as follows: that which is mature and turgid; that which is mature, but flaccid by reason of desiccation; and that which is young. Table 28 shows the relative activity of all three at $30^{\circ}, 35^{\circ}, 40^{\circ}$, and $45^{\circ} \mathrm{C}$. These temperatures were chosen for experimentation as representing the normal and the higher ranges to which the plant may be subjected in its native habitat during the summer season.

It is evident that the young joints, either those which arise in the natural course of events as a result of the summer rains or those the formation of which is induced by irrigation, have a much higher rate of carbon dioxide evolution than the mature ones. If the comparison is made on the basis of equal weights of fresh tissue the amount given off is from 80 to 100 per cent higher in the young material than in the old. The disparity is considerably greater if the dry weight is taken as the standard since the young tissue contains proportionally more water, the excess of carbon dioxide produced by the young joints over that of the mature ones being from 118 per cent at the lowest temperature, to almost 200 per cent at $40^{\circ} \mathrm{C}$. Reference to table 26 will show this. It will be remembered that the young tissue is also more acid than the older parts, which indicates what the subsequent experiments show, that acidity and evolution of carbon dioxide are closely connected.

In comparing the turgid and flaccid joints there does not appear to be as great a difference in the rate at which the gas is given off as might be expected. On the basis of fresh weights, the latter appear to be more active than the former, which is of course due to the considerably larger amount of dry substance in the flaccid material over that in the turgid when equal weights of fresh tissue are taken. The true comparison should be made on the basis of dry weights. With this standard it will be seen that the flaccid material at $30^{\circ} \mathrm{C}$. gives out about 90 per cent as much carbon dioxide as does the turgid, diminishing proportionally with rising temperature until at $45^{\circ} \mathrm{C}$. it is not much over 80 per cent. The rate, however, is considerable even in the most desiccated and shriveled plants found under normal conditions. It was, indeed, a matter of some surprise to find such an active evolution of carbon dioxide with the tissues in an apparently quiescent condition. It appears that the waterbalance maintained in the absence of external water-supply, while not sufficient to keep the cells of the plant turgid or to afford the conditions necessary for growth, was evidently enough to allow for a not very greatly diminished metabolic activity. Thus it can hardly be said that the cacti enter into a period of rest when they become desiccated during the dry season. This probably applies to the constructive as well as to the destructive processes, and, as will be seen for reasons given later, it seems not unlikely that the actual accumulation of substance by this group of plants takes place not so much during the hot and relatively moist period of the summer rains as 
during the cooler periods, when the external conditions are much drier. As this point is brought out better in the discussion of the gas-interchange experiments, further comment will be deferred until they are reached.

The various points referred to above are brought out in table 26, which gives averages of the experiments, which are shown in full in table 28.

TABLE 26.

\begin{tabular}{|c|c|c|c|c|c|c|}
\hline \multirow{2}{*}{ Temp. } & \multicolumn{3}{|c|}{$\begin{array}{c}\text { Carbon dioxide per gram-hour, } \\
\text { fresh weight. }\end{array}$} & \multicolumn{3}{|c|}{$\begin{array}{c}\text { Carbon dioxide per gram-hour, } \\
\text { dry weight. }\end{array}$} \\
\cline { 2 - 7 } & Turgid. & Flaceid. & Young. & Turgid. & Flacoid. & Young. \\
\hline & & & & & & \\
${ }^{\circ} C$. & $m g$. & $m g$. & $m g$. & $m g$. & $m g$. & $m g$. \\
30 & 0.12 & 0.16 & 0.22 & 0.62 & 0.55 & 1.35 \\
35 & 0.17 & 0.22 & 0.29 & 0.84 & 0.74 & 1.84 \\
40 & 0.24 & 0.30 & 0.48 & 1.22 & 1.03 & 3.05 \\
45 & 0.35 & 0.41 & 0.61 & 1.78 & 1.44 & 3.85 \\
\hline
\end{tabular}

The acidities of the juice were also determined in connection with this series, using parallel material at the end of each temperature period. There is, of course, a fall in acidity with the rising temperature, which is greatest in the young joints where there is the largest evolution of carbon dioxide. It is least in the flaccid specimens where the acidity is already low. It does not appear, however, that there is an exact relation between this fall of acidity and the respiration-rate, for the disparity between the loss of acid in the turgid and flaccid material is much greater than the difference of the amount of carbon dioxide evolved. Nor, indeed, is the difference in the rate of acidity decrease at $40^{\circ}$ and $45^{\circ}$ in correspondence with the increase in respiration. Other evidence will be given to show that the breaking down of the acid undoubtedly influences the quantity of carbon dioxide produced, but it seems that it is not the whole course of the formation of that waste product.

The averages of the acidity decrease may be compared with the rates of carbon dioxide formation given above. These figures are in terms of cubic centimeters of $\mathrm{N} / 10 \mathrm{KOH}$ per cubic centimeter of juice and are given in table 27.

TABLE 27.

\begin{tabular}{|c|c|c|c|}
\hline Temp. & $\begin{array}{c}\text { Mature- } \\
\text { turgid. }\end{array}$ & $\begin{array}{c}\text { Mature- } \\
\text { flaceid. }\end{array}$ & Young. \\
\hline${ }^{\circ} \mathrm{C}$. & & & \\
30 & 1.44 & 0.85 & 1.98 \\
35 & 1.29 & 0.79 & 1.76 \\
40 & 1.15 & 0.72 & 1.41 \\
45 & 1.07 & 0.65 & 1.23 \\
\hline
\end{tabular}

That there is, however, some relation between acidity and the rate at which carbon dioxide is evolved is shown by a series of experiments at approximately the same temperature, but at widely differing acidities (tables 29 and 30). The relation is not entirely constant, but points only in one direction. Taking the averages of the three series with turgid joints (table 29), the forenoon 
acidity was relatively high, being 1.03 per cubic centimeter juice, and the amount of carbon dioxide that was liberated was $0.72 \mathrm{mg}$. per gram-hour, dry weight; while in the afternoon, when the acidity had sunk to 0.38 per cubic centimeter, it was only $0.42 \mathrm{mg}$. per gram-hour. It is to be remembered that in the first case the acidity was falling, though not very greatly, while in the second case it was already low and was rising slightly. A similar state of affairs is to be observed in the three series with young joints. The evolution of carbon dioxide in the morning, which was $4.08 \mathrm{mg}$. per gram-hour, dryweight, was accompanied by an initial acidity equivalent of 1.49 per cubic centimeter, while in the afternoon, when the acidity had fallen to 0.28 per cubic centimeter, the amount of the gas given off was only $1.81 \mathrm{mg}$. for the same unit. This was in the face of the fact that the temperature in the afternoon was, if anything, slightly higher than in the morning.

The results of the temperature series already discussed might seem at first sight to be antagonistic to that which has just been said, but a closer consideration shows that there is no real contradiction. In all of the experiments given in table 28 the acidity was fairly high and was falling, and so it is only with the morning determinations that they should be compared. It is to be regretted that we have no determinations of the effect of temperature upon tissue with low acidity.

The general conclusions which seem justified from these data are that the higher the initial acidity the higher also is the rate of respiration, and the lower it is the lower also will the rate be. Plants of high acidity kept in the dark at normal temperatures, while they do not show a very great decrease in acidcontent, do not ordinarily show an increase thereof. On the other hand, plants of low acidity in the dark at temperatures not above $35^{\circ} \mathrm{C}$. universally show a gain in acid-content up to a certain point. Thus it would seem that the formation of acid is accompanied with a decreased carbon-dioxide formation, which is to be expected. Again, fuller discussion must be deferred until the consideration of the gas-interchange determinations which also bear upon this question.

During the normal day in the warm seasons in their native habitat around Tucson, the cacti must be subjected at times to temperatures as high as $50^{\circ} \mathrm{C}$., when the fact is taken into consideration that within the tissue itself the temperature rises several degrees above the air maximum. This phenomenon has already been spoken of in connection with the course of acidity from observations made in April 1911. A more extended series of observations on this point were made during the summer of 1912. With an external maximum of $45^{\circ} \mathrm{C}$, the temperature within the joint was found to be $47.5^{\circ} \mathrm{C}$. In order to determine how such high temperatures affect carbon dioxide evolution, three series were made at temperatures from $35^{\circ}$ to $65^{\circ} \mathrm{C}$., at 5-degree intervals (table 31 ). In all cases it will be seen that the maximum carbon-dioxide production is at $45^{\circ} \mathrm{C}$., and it is almost twice that at $35^{\circ} \mathrm{C}$. At $50^{\circ} \mathrm{C}$. in two cases there was a somewhat greater evolution of earbon dioxide than at $40^{\circ} \mathrm{C}$, , but in one case slightly less. Even at $55^{\circ} \mathrm{C}$. there is still as much as at $40^{\circ} \mathrm{C}$., while at $60^{\circ} \mathrm{C}$. the amount of carbon dioxide formed is about that found at $35^{\circ} \mathrm{C}$, showing a diminution from the $55^{\circ} \mathrm{C}$. rate. At $65^{\circ} \mathrm{C}$. there is still some carbon dioxide given off, though much below the normal. It is hardly to be supposed that the tissues are still alive at tempera- 
tures like $60^{\circ}$ or $65^{\circ} \mathrm{C}$, and it is doubtful if they are at $55^{\circ} \mathrm{C}$. The carbon dioxide given ofi at these temperatures is probably either that which is held dissolved in the cell-contents or that which is formed by the action of the high temperatures in breaking up unstable organic compounds, entirely aside from life processes, or perhaps both. Indeed, in dealing with such massive tissues, results which seem to indicate a real respiratory curve must be accepted with great caution. That there does appear here to be a definite maximum at $45^{\circ} \mathrm{C}$., as indicated by the diminished activity at $50^{\circ} \mathrm{C}$, where the tissues must still be alive, is an interesting point and merits further investigation, bearing in mind, however, the possible sources of confusion mentioned above.

That rise in temperature by itself affects acidity as well as the rate of respiration has been shown, and this is further borne out by the behavior of the plant under conditions necessitating intramolecular respiration. Data for the production of carbon dioxide in air in comparison with that in hydrogen and in nitrogen are given in tables 32,33 , and 34 . At relatively low temperatures, that is $20^{\circ}$ to $21^{\circ} \mathrm{C}$., the intramolecular respiration is less than two-thirds that of the normal, the actual ratio from averages of the experiments carried out being 28 to 17 ; but it is noticeable that at a higher temperature, to wit, $35^{\circ} \mathrm{C}$., there is a much closer approximation of the two. Under these conditions the ratio becomes more nearly 6 to 5 , or, in other words, intramolecular respiration increases more rapidly with rising temperature than does the normal. Why these cacti have such a high intramolecular respiration is puzzling. That the evolution of carbon dioxide can be due (directly, at least) to the diminution of acid in the tissues does not seem probable, for their breaking down is to a large extent dependent upon an adequate supply of oxygen. Rather, it serves as an additional reason for not considering deacidification as the only source for the evolution of carbon dioxide by the plant. If, as for good reasons is usually assumed, the massive tissues of such succulent plants are not easily accessible to the oxygen of the air, one can see, in this phenomenon of intramolecular respiration as in acid formation, a correlation of function with morphological structure. While, of course, the carbon dioxide formed during respiration diffuses out from the tissues into the surrounding air, it would seem probable that, at night at least, the gases held in the tissues must be very poor in oxygen, and consequently the conditions approach those where intramolecular respiration comes into play. The point is one of considerable interest and demands further investigation, particularly in regard to the nature of the inclosed gases and the rôle of intramolecular respiration in these plants. It was interesting to note that the tissues in the core of those joints kept free from oxygen and at a relatively high temperature for some time, were frequently in a state of semi-liquefaction.

The deacidification processes are known to be associated with the evolution of carbon dioxide; and, since sunlight is one of the most active agents in breaking down the plant acids, it seemed well to make a number of experiments to discover if an excess greater than the photosynthetic processes could utilize might be formed under illumination. Even under these conditions a considerable evolution of carbon dioxide was found, a circumstance already noted by Aubert ${ }^{a}$ in the case of certain cacti and by Garreau ${ }^{b}$ with plants under feeble light. The results of these experiments are set forth in table 35.

Aubert. Recherches sur les plantes grasses. 2d part, p. 77, Thesis, Paris, 1892.

${ }^{b}$ Garreau. Annal. de sci. nat. Botanique, Series 3, vol. Xv, p. 6, 1851, 1892. 
In the three controls in darkness, irrespective of temperature, there was an average carbon-dioxide production of $0.43 \mathrm{mg}$. per gram-hour, fresh weight. The same plants, under similar temperatures in the diffuse light from a north window of the laboratory, gave out about half that quantity of the gas$0.21 \mathrm{mg}$. per gram-hour-and, exposed to the most direct sunlight possible in an inclosed apparatus, produced an amount of carbon dioxide per gram-hour that was slightly more than one-third of that given out in darkness $(i . e$, $0.147 \mathrm{mg}$. per gram-hour). In the two series with young material a similar state of affairs obtained, except that while the rate in darkness and diffuse light is considerably higher than in sunlight, it is not correspondingly so. The amount of carbon dioxide given off per gram-hour is as follows: darkness, $0.96 \mathrm{mg}$; d diffuse light, $0.48 \mathrm{mg}$.; sunlight, $0.18 \mathrm{mg}$. The greater photosynthetic activity of the young tissue probably explains its difference in this regard from the mature.

It is debatable whether we have in this case true respiratory activity, for it seems probable that the evolution of the carbon dioxide, or at least a portion of it, is due to some cause other than the action of the living protoplasm itself. It is also probable that the actual source of the gas is from the mere breaking down of the acids present by the effect of sunlight, largely irrespective of the true respiratory functions. That the latter may be the case is indicated not only by what we know of the action of light on certain organic acids in vitro, apropos of which Spoehr's recent work has already been referred to, but also by the behavior of the plants at temperatures as high as $60^{\circ}$ to $65^{\circ} \mathrm{C}$. As the previously described results show, there is a considerable evolution of carbon dioxide under high-temperature conditions where the protoplasm can not possibly be living. In other words, then, it is possible that there may be apparent evidences of respiration when that function is not really concerned. However that may be, it is interesting to note that in some way more carbon dioxide may be produced by the cacti in direct sunlight than can be utilized by the photosynthetic machinery of the plant.

In these experiments every possible care was taken to insure that the evolution of gas in sunlight and diffuse light was not due to any extraneous organism. In the first place, the joints used were inspected with more than usual care, both before and after the experiments, to see if any insect grubs were present in the tissues. In every case no indication of any animal parasite was to be found. The joints used were exceptionally healthy in appearance. Although the possibility of the presence of bacteria in quantity sufficient to affect the respiration markedly was exceedingly improbable, these organisms were guarded against. In the last four series the joints were washed in a dilute solution of formalin and then rinsed in freshly boiled distilled water. The fact that control tests as well as the first two of the series showed no essential difference in the amount of carbon dioxide evolved showed not only that the question of the presence of superficially growing bacteria need not be considered, but also that the method of treatment with formalin was harmless to the material used. In addition to these precautions, toluol vapor was drawn through the whole system of the apparatus with the air-current. It was always the practice in the use of the Pettenkofer apparatus to test it from time to time for possible accidental sources of carbon dioxide, and in these experiments it was subjected to especially careful scrutiny. At the end of the series 
the apparatus was run without any plants in the receiver for 3 hours and there was absolutely no indication of any precipitate in the barium-hydroxide absorption tubes. It may be safely affirmed that whatever carbon dioxide was found came from the plants themselves and that these plants were entirely normal and healthy.

The sunlight to which the material was exposed was as direct and as uninfluenced by interposed screens as was possible with the apparatus at hand. The method, previously referred to, of immersion in clear water cooled with ice was resorted to in order to prevent undue rise in temperature. It is realized that some of the intensity of the sunlight is lost in transmission through the glass and the water and that the results do not give the entire possible effect of exposure to the sun. For this latter purpose it would be necessary to utilize quartz or special glass for the receiver and cool it by some device which did not require the immersion in water. With such an apparatus one might indeed obtain an even greater evolution of carbon dioxide. The figures are under rather than over the possible ones.

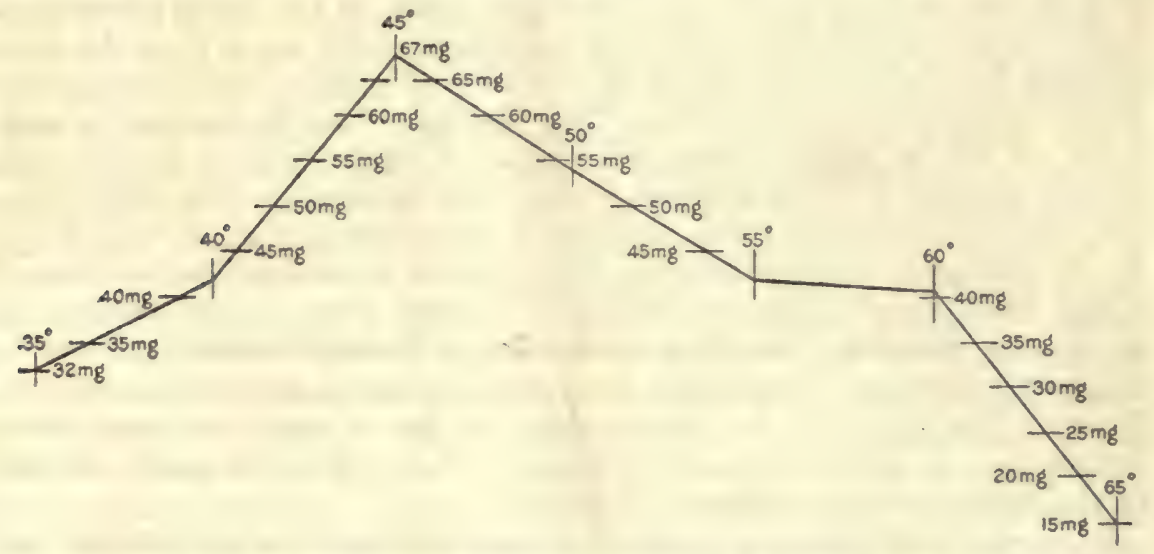

F1G. 5.-Graph showing rate of evolution of carbon dioxide by Opuntia versicolor at different temperatures. In milligrams of $\mathrm{CO}_{2}$ per gram hour. The data are from table 31 .

\section{WOUND RESPIRATION.}

That the small injury resulting from the removal of joints from the cactus plants does not produce any measurable wound respiration has already been shown in the description of experimental methods and precautions, and further reference is unnecessary; but that a definite wound respiration follows a considerable injury was established (tables 36,37 ) and is of some interest, especially in connection with the acidity relations. The sudden temporary rise in the amount of carbon dioxide, which has been found with other massive tissues immediately after wounding, ${ }^{a}$ was not observed. This abrupt rise has been shown to be due to gas held in the tissue which escapes because of the mechanical effect of the injury. It it not to be supposed that it is absent in the case of the cacti, but rather that, owing to the great quantity of water in these succulent plants, it is probably held in solution. During the third hour

aRichards, H. M. The Respiration of Wounded Plants, Annals of Botany, pp. 531-582, vol. $10,1896$. 
after injury there is a marked increase in the respiration which, with slight oscillations, rises to its maximum in 26 hours. After that period there is a slow decline in the amount of carbon dioxide evolved until by the beginning of the fourth day it is normal again (fig. 5).

Two other partial series were made in connection with the variation in acidity which is consequent upon wounding. It has been shown that acidity is influenced by traumatic reaction and that the acidity is considerably lower at the time of greatest respiration. The results of these two series (table 37) are consistent both with the previously described respiration effect and with the acidity determinations (table 21). Averaging the results in this case the maximum is at 24 hours after injury, at which time the acidity is lowest. As the healing processes set in and the carbon dioxide decreases in amount there is evidence of a rise in acidity. Entirely aside from the question of wound respiration in general, in this case the increase in carbon dioxide is very likely due to the more rapid oxidation of the organic acids, which, by reason of the exposure of a larger surface of tissue to the air, are more readily broken down. In that respect, as in the case of carbon-dioxide evolution in sunlight, the phenomenon may not be wholly a respiratory one in the strict sense of the term. That we have to do here with an oxidation process is brought out clearly by the experiment given in table 38 , which shows the wound respiration in relation to absence of oxygen. At both $20^{\circ} \mathrm{C}$. and $35^{\circ} \mathrm{C}$. the evolution of carbon dioxide is greatly reduced in an atmosphere of pure nitrogen; in the first case to less than one-third that in air and in the second to less than half. The respiration in the absence of oxygen is about that which would be expected in uninjured tissue.

\section{DIURNAL PERIODICITY IN RELATION TO TEMPERATURE.}

Three continuous series were carried through over periods of more than 24 hours under temperature conditions representing the diurnal change of an average day at Tucson in late spring (tables 39,40 , and 41). The objects were to plot the daily march of respiration and to determine how slow but continuous changes in temperature would affect the rate of carbon-dioxide production. The series was, of course, made with the receiver darkened, as it was not desired to complicate the question with photosynthetic action. In order that the temperature changes as they affect the tissues themselves could be noted, the thermometer in each case was thrust into one of the joints in the receiver. This was effected by boring a small hole longitudinally through a joint, which was then laid aside for a few days until the wound had healed. The temperature within the eactus joint lagged behind the air temperature in the receiver by about half an hour. In the tables it is the temperature within the tissue that is given.

The most interesting point which developed was the lag in the reaction to the temperature changes. In each case the minimum rate of carbon-dioxide production was about an hour later than the minimum temperature within the joint. Similarly the maximum respiratory activity was delayed. The accompanying graphs (fig. 6) bring this out clearly. In comparing these results with the diurnal acidity curve, it appears that the time of lowest acidity, especially when the acidity has been falling rapidly, must also be the time of the greatest evolution of carbon dioxide. But it must not 
be supposed for this reason that the alterations in acidity are dependent simply upon temperature changes. It has been shown previously that while high temperatures affect acidity to a certain extent, the decrease which is due to this cause is not nearly so great as that eaused by the photolytic action of sunlight. The fact that the carbon-dioxide output is so markedly influenced by temperature, falling as it does in the range of temperatures employed in these experiments to only 25 per cent of the maximum, gives another indication that decrease in acidity is probably not a respiratory phenomenon in the strictest sense. Were it so, temperature would be expected to exert as great an influence upon acidity as it does on the production of carbon dioxide, which is not the case.

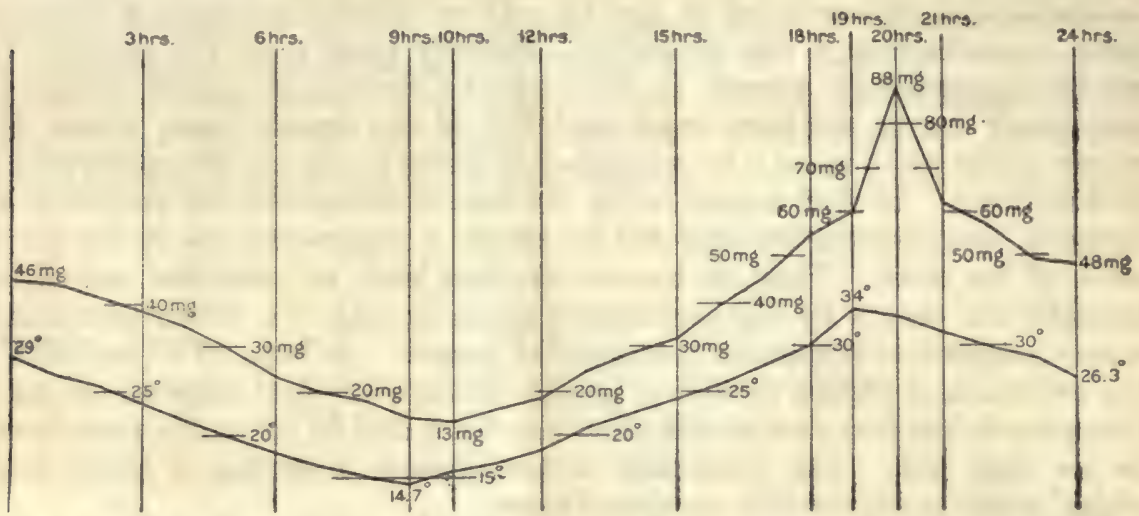

Fig. 6.-Graph showing evolution of carbon dioxide by Opuntia versicolor with progressively changing temperature.

In milligrams of $\mathrm{CO}_{2}$ per gram hour, fresh weight. The upper graph is of the $\mathrm{CO}_{2}$; the lower one of the temperature. The graphs are composite ones from the data given in tables 31,32 , and 33.

It is interesting to observe in these graphs how sharply the curve rises at $34^{\circ} \mathrm{C}$. and drops correspondingly rapidly as the temperature falls. At temperatures below $39^{\circ} \mathrm{C}$. this cactus is decidedly sluggish; but at $5^{\circ}$ higher, which may be considered as an average normal temperature in the sun, its production of carbon dioxide is not inconsiderable. The common statement of the exceedingly slow rate of respiratory activity in cacti is largely due, no doubt, to the fact that most investigators used temperatures optimal for the ordinary plant, but not so favorable for the cacti.

It is to be observed, in looking over the whole series of results, that there is a very considerable variation in the rate of carbon-dioxide evolution, even at similar temperatures. In general, the determinations made in New York with material sent from Tucson are higher than those made at Tucson itself. The material used in New York was all sent during the winter months and the joints used were those of the previous season's growth. They were fully mature, but at the same time were younger than the youngest mature joints used during the summer. This may very well account for their greater activity over those used the following summer. 


\section{EXPERIMENTAL DATA OF DETERMINATIONS WITH PETTENKOFER APPARATUS.}

TABLE 28.-Respiration and acidity of young, mature-turgid, and mature-flaccid joints of Opuntia versicolor at various temperatures.

The determinations were made in half-hour periods and the results are the averages of these, estimated in terms of milligrams of $\mathrm{CO}_{2}$ per hour. The number of periods from which the averages were made is indicated in the fifth column. No determinations were made until the material had been at least $1 \frac{1}{2}$ hours at the temperatures named. The acidities given were made from parallel material at the close of each temperature period, except the acidities at $45^{\circ} \mathrm{C}$., which were from the material used in the $\mathrm{CO}_{2}$ determinations. The experiments were made at Tucson, Arizona, in June and July 1912.

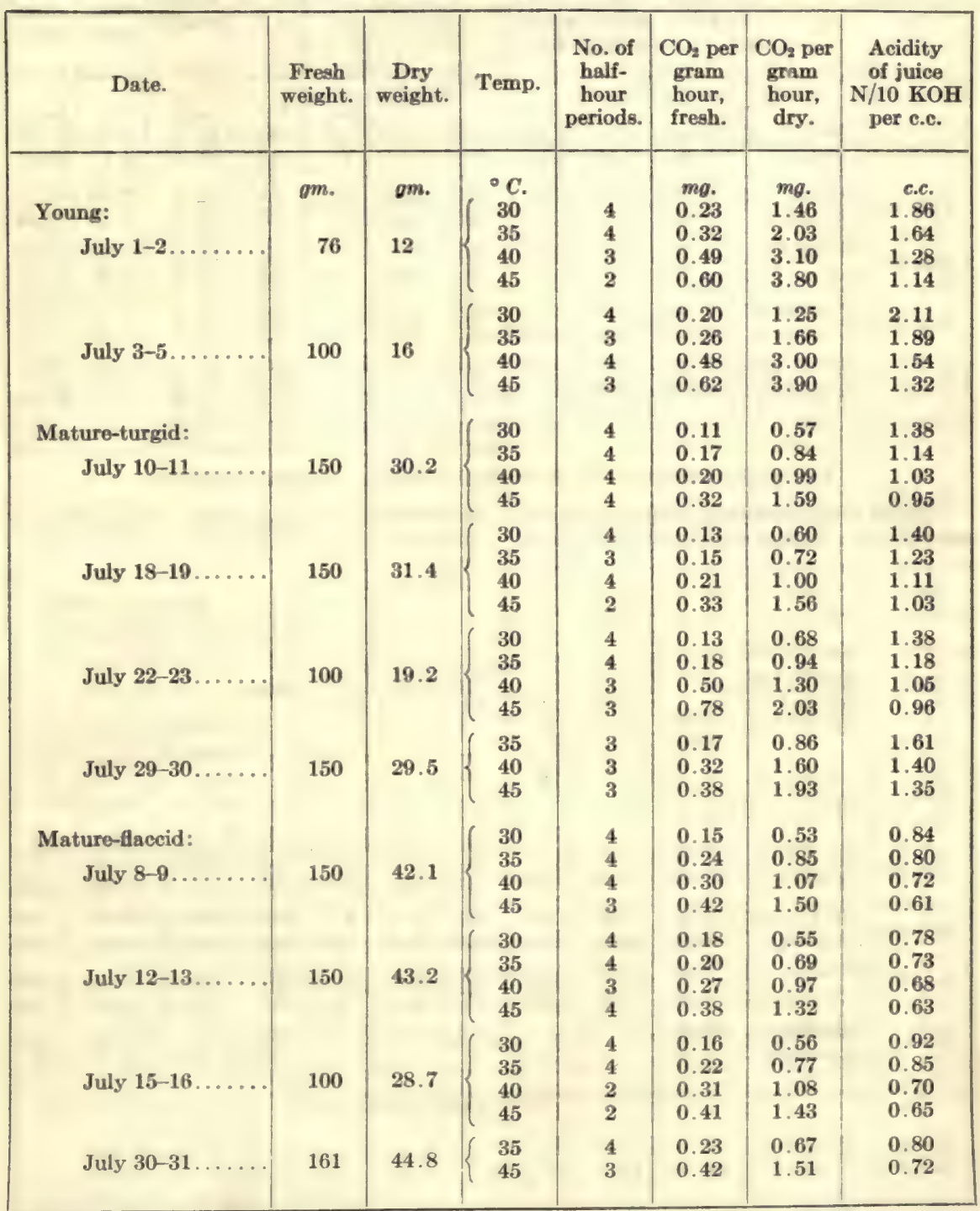


TABLE 29.-Respiration in relation to acidity. Opuntia versicolor.

Samples were taken during the morning and afternoon, directly from the plant in the open. The respiration in darkness was determined by the Pettenkofer apparatus and at the same time the acidity was recorded. The acidity is given in cubic centimeters of $\mathrm{N} / 10$ alkali and the respiration rate in milligrams of $\mathrm{CO}_{2}$ per hour. The material used was of the previous season's growth and turgid. The experiments were conducted at Tucson, Arizona, in July 1912.

\begin{tabular}{|c|c|c|c|c|c|c|c|c|c|c|c|}
\hline \multirow[b]{2}{*}{ Date. } & \multirow[b]{2}{*}{ Time begun. } & \multicolumn{3}{|c|}{ Acidity. } & \multirow[b]{2}{*}{$\begin{array}{c}\text { Fresh } \\
\text { wt. }\end{array}$} & \multirow[b]{2}{*}{$\begin{array}{l}\text { Dry } \\
\text { wt. }\end{array}$} & \multirow[b]{2}{*}{$\begin{array}{l}\text { Dura- } \\
\text { tion. }\end{array}$} & \multirow[b]{2}{*}{ Temp. } & \multicolumn{3}{|c|}{$\begin{array}{l}\text { Respiration, } \mathrm{CO}_{2} \\
\text { per hour. }\end{array}$} \\
\hline & & $\begin{array}{l}\text { Pure } \\
\text { juice. }\end{array}$ & $\left\{\begin{array}{c}\text { Total } \\
\text { per } \\
\text { gram, } \\
\text { fresh. }\end{array}\right.$ & $\begin{array}{c}\text { Total } \\
\text { per } \\
\text { gram, } \\
\text { dry. }\end{array}$ & & & & & $\begin{array}{l}\text { Entire } \\
\text { sample. }\end{array}$ & $\begin{array}{c}\text { Per } \\
\text { gram, } \\
\text { fresh. }\end{array}$ & $\begin{array}{c}\text { Per } \\
\text { gram, } \\
\text { dry. }\end{array}$ \\
\hline July 17. & $\left\{\begin{array}{r}10^{\mathrm{h}} 15^{\mathrm{m}} \mathrm{a} . \mathrm{m} . \\
4 \text { p.m..... }\end{array}\right.$ & $\begin{array}{l}0.80 \\
0.36\end{array}$ & $\begin{array}{l}0.75 \\
0.36\end{array}$ & $\begin{array}{l}3.95 \\
1.80\end{array}$ & $\begin{array}{l}150 \\
153\end{array}$ & $\begin{array}{l}31.0 \\
33.4\end{array}$ & $\begin{array}{l}h r 8 . \\
2 \frac{1}{2} \\
1 \frac{1}{4}\end{array}$ & $\begin{array}{l}{ }^{\circ} C . \\
34 \\
35\end{array}$ & $\begin{array}{r}m g \\
27.1 \\
17.0\end{array}$ & $\begin{array}{l}m g . \\
0.18 \\
0.11\end{array}$ & $\begin{array}{l}m o . \\
0.87 \\
0.51\end{array}$ \\
\hline July 18. & $\left\{\begin{array}{r}10 \text { a.m...... } \\
4 \text { p.m.... }\end{array}\right.$ & $\begin{array}{l}0.98 \\
0.42\end{array}$ & $\begin{array}{l}0.84 \\
0.31\end{array}$ & $\begin{array}{l}4.40 \\
2.00\end{array}$ & $\begin{array}{l}200 \\
205\end{array}$ & $\begin{array}{l}45.3 \\
44.5\end{array}$ & $\begin{array}{l}2 \frac{1}{4} \\
1 \frac{1}{2}\end{array}$ & $\begin{array}{l}34 \\
36\end{array}$ & $\begin{array}{l}35.2 \\
19.0\end{array}$ & $\begin{array}{l}0.18 \\
0.09\end{array}$ & $\begin{array}{l}0.78 \\
0.43\end{array}$ \\
\hline July 19. & $\left\{\begin{array}{l}9^{\mathrm{h}} 50^{\mathrm{m}} \mathrm{a} . \mathrm{m} . \\
4 \text { p.m. . . . . }\end{array}\right.$ & $\begin{array}{l}1.25 \\
0.42\end{array}$ & $\begin{array}{l}0.45 \\
0.18\end{array}$ & $\begin{array}{l}2.33 \\
0.93\end{array}$ & $\begin{array}{l}207 \\
212\end{array}$ & $\begin{array}{l}41.1 \\
42.0\end{array}$ & $\begin{array}{l}3 \\
1 \frac{1}{2}\end{array}$ & $\begin{array}{l}33 \\
35\end{array}$ & $\begin{array}{l}22.5 \\
15.4\end{array}$ & $\begin{array}{l}0.11 \\
0.07\end{array}$ & $\begin{array}{l}0.55 \\
0.37\end{array}$ \\
\hline July 21 . & $\left\{\begin{array}{lll}9^{\mathrm{h}} & 30^{\mathrm{m}} & \text { a.m. } \\
3 & 30 & \text { p.m. }\end{array}\right.$ & $\begin{array}{l}1.10 \\
0.31\end{array}$ & $\begin{array}{l}0.82 \\
0.29\end{array}$ & $\begin{array}{l}4.32 \\
1.55\end{array}$ & $\begin{array}{l}200 \\
210\end{array}$ & $\begin{array}{l}40.6 \\
41.9\end{array}$ & $\begin{array}{l}4 \\
2\end{array}$ & $\begin{array}{l}34 \\
35\end{array}$ & $\begin{array}{l}24.5 \\
13.7\end{array}$ & $\begin{array}{l}0.12 \\
0.07\end{array}$ & $\begin{array}{l}0.60 \\
0.32\end{array}$ \\
\hline Aver. . & $\left\{\begin{array}{l}\text { Morning. . . } \\
\text { Afternoon. }\end{array}\right.$ & $\begin{array}{l}1.03 \\
0.38\end{array}$ & $\begin{array}{l}0.74 \\
0.29\end{array}$ & $\begin{array}{l}3.75 \\
1.57\end{array}$ & & & & $\begin{array}{l}32.5 \\
35\end{array}$ & $\begin{array}{l}27.3 \\
16.3\end{array}$ & $\begin{array}{l}0.15 \\
0.08\end{array}$ & $\begin{array}{l}0.70 \\
0.41\end{array}$ \\
\hline
\end{tabular}

TABLE 30.-Respiration in relation to acidity. Opuntia versicolor.

Similar to the preceding series, except that the material used was young. The joints were very turgid and had well-developed leaves. The work was done at Tucson, in July 1912.

\begin{tabular}{|c|c|c|c|c|c|c|c|c|c|c|c|}
\hline \multirow[b]{2}{*}{ Date. } & \multirow{2}{*}{$\begin{array}{l}\text { Time of col- } \\
\text { lection and } \\
\text { beginning of } \\
\text { experiment. }\end{array}$} & \multicolumn{3}{|c|}{ Acidity. } & \multirow{2}{*}{$\begin{array}{l}\text { Fresh } \\
\text { wt. }\end{array}$} & \multirow{2}{*}{$\begin{array}{l}\text { Dry } \\
\text { wt. }\end{array}$} & \multirow{2}{*}{$\begin{array}{l}\text { Dura- } \\
\text { tion. }\end{array}$} & \multirow[b]{2}{*}{ Temp. } & \multicolumn{3}{|c|}{$\begin{array}{l}\text { Respiration, } \mathrm{CO}_{2} \\
\text { per hour. }\end{array}$} \\
\hline & & $\begin{array}{l}\text { Pure } \\
\text { juice. }\end{array}$ & $\begin{array}{l}\text { Total } \\
\text { per } \\
\text { gram, } \\
\text { fresh. }\end{array}$ & $\begin{array}{c}\text { Total } \\
\text { per } \\
\text { gram, } \\
\text { dry. }\end{array}$ & & & & & $\begin{array}{l}\text { Entire } \\
\text { sample. }\end{array}$ & $\begin{array}{c}\text { Per } \\
\text { gram, } \\
\text { fresh. }\end{array}$ & $\begin{array}{c}\text { Per } \\
\text { gram, } \\
\text { dry. }\end{array}$ \\
\hline July 29. & $\left\{\begin{array}{c}10^{\mathrm{h}} 30^{\mathrm{m}} \text { a.m.m. } \\
4 \mathrm{p} . \mathrm{m} . . . .\end{array}\right.$ & $\begin{array}{l}1.09 \\
0.23\end{array}$ & $\begin{array}{l}0.89 \\
0.19\end{array}$ & $\begin{array}{l}6.32 \\
1.40\end{array}$ & $\begin{array}{c}g m . \\
180 \\
141\end{array}$ & $\begin{array}{l}g m . \\
27.9 \\
20.5\end{array}$ & \begin{tabular}{|c|}
$h r s$. \\
$2 \frac{1}{2}$ \\
$1 \frac{1}{2}$
\end{tabular} & $\begin{array}{l}{ }^{\circ} C . \\
28 \\
29\end{array}$ & $\begin{array}{r}m g . \\
104.5 \\
40.7\end{array}$ & $\begin{array}{l}m g . \\
0.58 \\
0.29\end{array}$ & $\begin{array}{l}m g . \\
3.74 \\
1.98\end{array}$ \\
\hline July 30 . & $\left\{\begin{array}{r}10^{\mathrm{h}} 15^{\mathrm{m}} \mathrm{a} . \mathrm{m} \\
4 \text { p.m. . . . }\end{array}\right.$ & $\begin{array}{l}1.82 \\
0.31\end{array}$ & $\begin{array}{l}1.20 \\
0.22\end{array}$ & $\begin{array}{l}7.10 \\
1.34\end{array}$ & $\begin{array}{l}150 \\
150\end{array}$ & $\begin{array}{l}22.9 \\
23.6\end{array}$ & $\begin{array}{l}3 \\
1 \frac{1}{2}\end{array}$ & $\begin{array}{l}32 \\
34\end{array}$ & $\begin{array}{l}92.0 \\
35.3\end{array}$ & $\begin{array}{l}0.61 \\
0.23\end{array}$ & $\begin{array}{l}4.02 \\
1.49\end{array}$ \\
\hline July 31 . & $\left\{\begin{array}{c}10 \text { a.m } \ldots . . \\
3^{\mathrm{h}} 30^{\mathrm{m}} \text { p.m }\end{array}\right.$ & $\begin{array}{l}1.56 \\
0.29\end{array}$ & $\begin{array}{l}0.98 \\
0.23\end{array}$ & $\begin{array}{l}6.15 \\
1.38\end{array}$ & $\begin{array}{l}200 \\
135\end{array}$ & $\begin{array}{l}31.4 \\
20.1\end{array}$ & $\begin{array}{l}3 \\
1 \frac{3}{4}\end{array}$ & $\begin{array}{l}33 \\
35\end{array}$ & $\begin{array}{r}141.0 \\
39.4\end{array}$ & $\begin{array}{l}0.70 \\
0.29\end{array}$ & $\begin{array}{l}4.49 \\
1.96\end{array}$ \\
\hline Aver. & $\left\{\begin{array}{l}\text { Morning.... } \\
\text { Afternoon . . }\end{array}\right.$ & $\begin{array}{l}1.49 \\
0.28\end{array}$ & & & & & & $\begin{array}{l}31 \\
33\end{array}$ & $\begin{array}{r}112.5 \\
38.5\end{array}$ & $\begin{array}{l}0.63 \\
0.27\end{array}$ & $\begin{array}{l}4.08 \\
1.81\end{array}$ \\
\hline
\end{tabular}


TABLE 31.-Evolution of $\mathrm{CO}_{2}$ at higher temperatures. Opuntia versicolor.

All of these determinations were made in New York in 1912 from material sent from Tucson. In all three series the material was treated in a similar way. Determinations were made only after the specimens had been for at least 2 hours under the temperature under investigation. The actual determinations were made in half-hour periods, but have been calculated in terms of whole hours for the sake of comparison with the standard of milligrams $\mathrm{CO}_{2}$ per hour, per gram fresh weight, which has been used throughout.

\begin{tabular}{|c|c|c|c|c|c|c|c|}
\hline & \multicolumn{7}{|c|}{$\mathrm{CO}_{2}$ per gram-hour, fresh weight. } \\
\hline & At $35^{\circ}$. & At $40^{\circ}$. & At $45^{\circ}$. & At $50^{\circ}$. & At $55^{\circ}$. & At $60^{\circ}$. & At $65^{\circ}$ \\
\hline I. Apr. 9-10, 1912, & $\begin{array}{r}m g . \\
0.57 \\
.59 \\
\ldots\end{array}$ & $\begin{array}{r}m g . \\
0.86 \\
.82 \\
.83\end{array}$ & $\begin{array}{r}m g . \\
0.97 \\
.89 \\
.87\end{array}$ & $\begin{array}{r}m g . \\
0.75 \\
.78 \\
.79\end{array}$ & $\begin{array}{l}m g . \\
\cdots \\
\cdots \\
\cdots\end{array}$ & $\begin{array}{l}m o . \\
\cdots \\
\cdots \\
\cdots\end{array}$ & $\begin{array}{l}m g . \\
\cdots \\
\cdots \\
\cdots\end{array}$ \\
\hline II. May 24-25, 1912 . & $\begin{array}{r}0.27 \\
.31 \\
\ldots .\end{array}$ & $\begin{array}{l}.36 \\
.35 \\
.41\end{array}$ & $\begin{array}{l}.58 \\
.62 \\
.69\end{array}$ & $\begin{array}{r}.54 \\
.52 \\
\ldots .\end{array}$ & $\begin{array}{r}0.43 \\
.40 \\
\ldots .\end{array}$ & $\begin{array}{r}0.35 \\
.33 \\
.26\end{array}$ & $\begin{array}{l}0.11 \\
\ldots \\
\cdots\end{array}$ \\
\hline III. Apr. 6-7, 1912 . & $\left\{\begin{array}{r}0.38 \\
.32 \\
\ldots\end{array}\right.$ & $\begin{array}{r}.44 \\
.52 \\
\ldots .\end{array}$ & $\begin{array}{l}.68 \\
.75 \\
.69\end{array}$ & $\begin{array}{r}.58 \\
.51 \\
\ldots .\end{array}$ & $\begin{array}{r}.42 \\
.44 \\
\ldots .\end{array}$ & $\begin{array}{c}.38 \\
.33 \\
\ldots .\end{array}$ & $\begin{array}{l}.20 \\
.18 \\
.09\end{array}$ \\
\hline
\end{tabular}

TABLE 32.-Intramolecular respiration.

The material used was 15 joints of the previous season's growth of Opuntia versicolor having a fresh weight of 336 grams. Respiration was observed in air and in pure hydrogen at $20^{\circ}$ to $21^{\circ}$ and $34^{\circ}$ to $36^{\circ} \mathrm{C}$. The experiment was carried on at New York, April 1 to 3, 1912, with material sent from Tueson, Arizona.

\begin{tabular}{|c|c|c|c|c|}
\hline Time. & Duration. & Temp. & Total $\mathrm{CO}_{2}$. & $\begin{array}{l}\mathrm{CO}_{2} \text { per } \\
\text { gram, } \\
\text { hour. }\end{array}$ \\
\hline 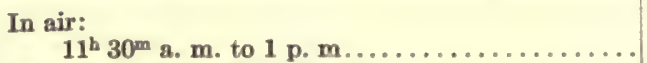 & $\begin{array}{c}\text { hours. } \\
1 \frac{1}{2}\end{array}$ & $\begin{array}{l}{ }^{\circ} \mathrm{C} . \\
21\end{array}$ & $\begin{array}{l}m g . \\
111.00\end{array}$ & $\begin{array}{l}m g . \\
0.22\end{array}$ \\
\hline In hydrogen; ran blank for 1 hour: & & & & \\
\hline 2 to $3 \mathrm{p} . \mathrm{m} \ldots \ldots \ldots \ldots \ldots \ldots$ & 1 & 21 & 42.50 & .13 \\
\hline 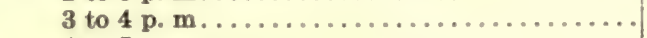 & 1 & 21 & 45.50 & .14 \\
\hline 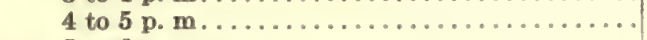 & 1 & 20 & 46.25 & .14 \\
\hline 5 to 6 p. m..... & 1 & 21 & 46.25 & .14 \\
\hline In air; ran blank for $1 \frac{1}{2}$ hours: & & & & \\
\hline $7^{\mathrm{b}} 30^{\mathrm{m}}$ to $8^{\mathrm{h}} 30^{\mathrm{m}}$ p. m........... & 1 & 21 & 83.00 & .25 \\
\hline 830 to 930 p. $\mathrm{m} \ldots \ldots \ldots$ & 1 & 20.5 & 77.25 & .23 \\
\hline 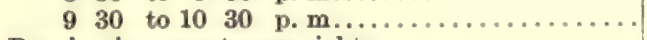 & 1 & 20 & 74.00 & .22 \\
\hline $\begin{array}{l}\text { Ran in air-current over night: } \\
9^{\mathrm{b}} 40^{\mathrm{m}} \text { to } 10^{\mathrm{h}} 40^{\mathrm{m}} \text { a. m..... }\end{array}$ & 1 & 20 & 84.75 & .25 \\
\hline In hydrogen; ran blank from $10^{\mathrm{h}} 40^{\mathrm{m}} \mathrm{a} . \mathrm{m} . \mathrm{:}$ & & & 07.70 & .20 \\
\hline 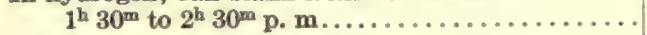 & 1 & 20 & 48.50 & .14 \\
\hline 230 to 330 p. $m \ldots \ldots \ldots \ldots \ldots \ldots$ & 1 & 20 & 46.25 & .14 \\
\hline 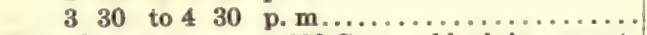 & 1 & 20 & 48.25 & .14 \\
\hline $\begin{array}{l}\text { Raised temperature to } 35^{\circ} \mathrm{C} \text {.; ran blank in current } \\
\text { of hydrogen: }\end{array}$ & & & & \\
\hline 9 to 10 p. m. $\ldots \ldots \ldots \ldots \ldots \ldots \ldots \ldots$ & 1 & 35 & 149.25 & .44 \\
\hline In air; ran blank 1 hour: & & & & \\
\hline $\begin{array}{l}11 \text { to } 12 \text { midnight. ......................... } \\
\text { Ran blank over night; raised temperature to } 35^{\circ} \\
\text { at } 8^{\mathrm{h}} 30^{\mathrm{m}} \text { g. m.: }\end{array}$ & 1 & 35 & 140.25 & .42 \\
\hline 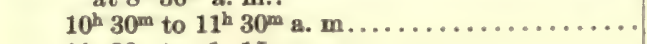 & 1 & 35 & 122.00 & .36 \\
\hline 1130 to 115 p. m............ & $1 \frac{3}{6}$ & 35 & 189.50 & .32 \\
\hline In hydrogen; ran blank for 1 hour: & & & & \\
\hline 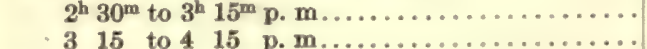 & $\frac{3}{4}$ & $\begin{array}{l}35 \\
35\end{array}$ & $\begin{array}{l}87.00 \\
85.75\end{array}$ & $\begin{array}{l}.35 \\
.34\end{array}$ \\
\hline
\end{tabular}




\section{TABLE 33.-Intramolecular respiration.}

The material used was 12 mature joints of Opuntia versicolor of the previous season's growth, having a fresh weight of 320 grams. Respiration was observed in air and in pure nitrogen at $21^{\circ}$ and $35^{\circ} \mathrm{C}$. The experiment was carried on in New York with material sent from Tucson.

\begin{tabular}{|c|c|c|c|c|}
\hline Time. & Duration. & Temp. & Total $\mathrm{CO}_{2}$ & $\begin{array}{l}\mathrm{CO}_{2} \text { per } \\
\text { gram, } \\
\text { hour. }\end{array}$ \\
\hline 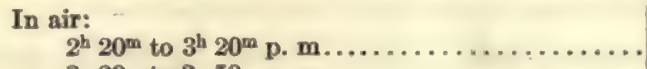 & hrs. & ${ }^{\circ} \mathrm{C}$. & $\begin{array}{l}m g . \\
78.75\end{array}$ & $\begin{array}{l}m g . \\
0.24\end{array}$ \\
\hline 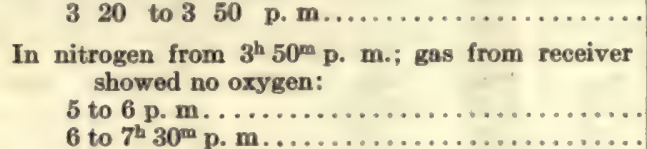 & $\begin{array}{l}1 \\
1 \frac{1}{2}\end{array}$ & $\begin{array}{l}21 \\
21\end{array}$ & $\begin{array}{l}53.50 \\
72.50\end{array}$ & $\begin{array}{l}.17 \\
.15\end{array}$ \\
\hline 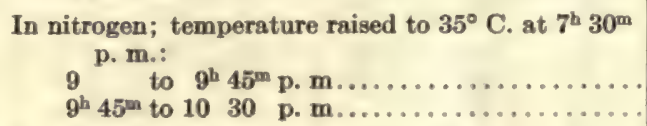 & $\frac{3}{\frac{3}{2}}$ & $\begin{array}{l}35 \\
35\end{array}$ & $\begin{array}{l}71.00 \\
79.50\end{array}$ & $\begin{array}{l}.30 \\
.33\end{array}$ \\
\hline 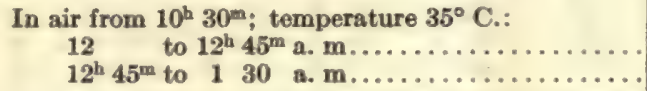 & $\begin{array}{l}\frac{3}{4} \\
\frac{1}{4}\end{array}$ & $\begin{array}{l}35 \\
35\end{array}$ & $\begin{array}{l}90.75 \\
91.50\end{array}$ & $\begin{array}{l}.38 \\
.38\end{array}$ \\
\hline
\end{tabular}

TABLE 34.-Intramolecular respiration.

Carried on in New York with material sent from Tucson, consisting of 9 mature joints of Opuntia versicolor, of the previous season's growth, with a fresh weight of 200 grams. Respiration was observed in air and in pure nitrogen at $21^{\circ}$ and $35^{\circ} \mathrm{C}$.

\begin{tabular}{|c|c|c|c|c|}
\hline Time. & Duration. & Temp. & Total $\mathrm{CO}_{2}$ & $\begin{array}{l}\mathrm{CO}_{2} \text { per } \\
\text { gram- } \\
\text { hour. }\end{array}$ \\
\hline 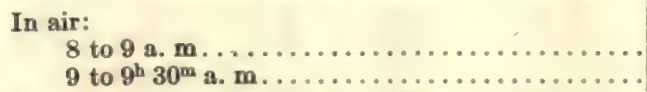 & $\begin{array}{c}\text { hrs. } \\
1 \\
\frac{1}{2}\end{array}$ & $\begin{array}{l}{ }^{\circ} \mathrm{C} . \\
21 \\
21\end{array}$ & $\begin{array}{l}m g . \\
82.50 \\
42.00\end{array}$ & $\begin{array}{r}m g . \\
0.41 \\
.42\end{array}$ \\
\hline $\begin{array}{l}\text { In nitrogen from } 9^{\mathrm{h}} 30^{\mathrm{m}} \text {; gas from receiver showed } \\
\text { no oxygen: }\end{array}$ & & & & \\
\hline 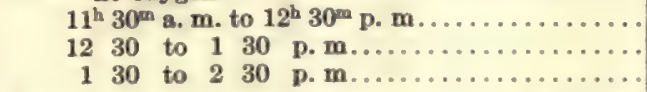 & $\begin{array}{l}1 \\
1 \\
1\end{array}$ & $\begin{array}{l}21 \\
21 \\
21\end{array}$ & $\begin{array}{l}52.00 \\
56.50 \\
52.00\end{array}$ & $\begin{array}{l}.26 \\
.28 \\
.26\end{array}$ \\
\hline 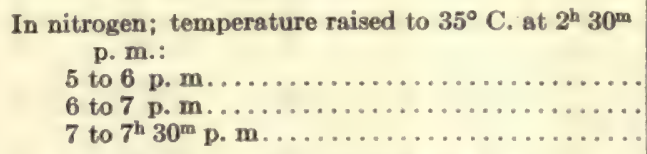 & $\begin{array}{l}1 \\
1 \\
{ }_{3}\end{array}$ & $\begin{array}{l}35 \\
35 \\
35\end{array}$ & $\begin{array}{r}160.25 \\
152.15 \\
78.00\end{array}$ & $\begin{array}{l}.80 \\
.76 \\
.78\end{array}$ \\
\hline 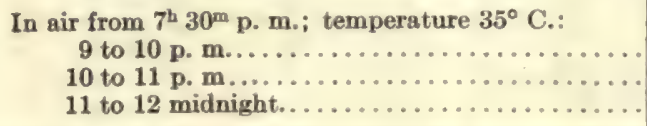 & $\begin{array}{l}1 \\
1 \\
1\end{array}$ & $\begin{array}{l}35 \\
35 \\
35\end{array}$ & $\begin{array}{l}184.00 \\
180.00 \\
188.25\end{array}$ & $\begin{array}{l}.92 \\
.90 \\
.94\end{array}$ \\
\hline
\end{tabular}


TABLE 35.-Evolution of $\mathrm{CO}_{2}$ in sunlight and in diffuse light, compared with that in darkness.

The experiment was made with Opuntia versicolor, at Tueson, July 23, 29, 30, 31, and August 2 and 3,1912. The joints exposed to sunlight were in a glass receiver immersed in water cooled with ice; those in diffuse light were in the same receiver and were placed out of doors in the shade. The apparatus was very carefully tested after the determinations, to make sure that there could be no vitiation of the result from leakage. After running blank for 3 hours without any plants in the receiver no trace of $\mathrm{CO}_{2}$ was found.

\begin{tabular}{|c|c|c|c|c|c|c|c|c|c|c|c|c|c|}
\hline \multirow[b]{2}{*}{$\begin{array}{c}\text { No. } \\
\text { of } \\
\text { exp. }\end{array}$} & \multirow[b]{2}{*}{ Material. } & \multirow[b]{2}{*}{$\begin{array}{c}\text { Fresh } \\
\text { wt. }\end{array}$} & \multirow[b]{2}{*}{$\begin{array}{l}\text { Dry } \\
\text { wt. }\end{array}$} & \multirow[b]{2}{*}{ Temp. } & \multicolumn{3}{|c|}{ In sunlight. } & \multicolumn{3}{|c|}{ In diffuse light. } & \multicolumn{3}{|c|}{ In darkness. } \\
\hline & & & & & $\begin{array}{c}\mathrm{Du}- \\
\mathrm{ra}- \\
\text { tion. }\end{array}$ & $\begin{array}{l}\text { Total } \\
\mathrm{CO}_{2} .\end{array}$ & $\begin{array}{l}\mathrm{CO}_{2} \\
\text { per } \\
\text { gram- } \\
\text { hour. }\end{array}$ & $\begin{array}{c}\mathrm{Du}- \\
\mathrm{ra-} \\
\text { tion. }\end{array}$ & $\begin{array}{l}\text { Total } \\
\mathrm{CO}_{2} \text {. }\end{array}$ & $\begin{array}{l}\mathrm{CO}_{2} \\
\text { per } \\
\text { gram- } \\
\text { hour. }\end{array}$ & $\begin{array}{c}\mathrm{Du}- \\
\mathrm{ra}- \\
\text { tion. }\end{array}$ & $\begin{array}{l}\text { Total } \\
\mathrm{CO}_{2} .\end{array}$ & $\begin{array}{l}\mathrm{CO}_{2} \\
\text { per } \\
\text { gram- } \\
\text { hour. }\end{array}$ \\
\hline 1 & Mat & gms. & gms. & ${ }^{\circ} \mathrm{C}$ & hrs. & $m g$. & mg. & hrs. & mo. & $m g$. & hrs. & $m g$. & mo. \\
\hline & turgid. & 255 & 51.2 & $20-21$ & & & & 3 & 16.5 & 0.02 & 3 & 21.0 & 0.03 \\
\hline 2 & Do.. & 250 & 50 & $35-37$ & 4 & 96.75 & 0.09 & $2 \frac{3}{4}$ & 109.25 & 0.16 & 2 & 220.0 & 0.44 \\
\hline 3 & Do. & 200 & 41.4 & 30 & 3 & 76.50 & 0.13 & 1 & 35.7 & 0.18 & 2 & 94.8 & 0.27 \\
\hline 4 & Do. & 282 & 56 & $36-38$ & 2 & 124.00 & 0.22 & 2 & 167.5 & & 2 & 305 & 0.55 \\
\hline 5 & Young & 195 & 31.4 & $35-36$ & 3 & 72.00 & 0.22 & 2 & 216.75 & 0.56 & 2 & 375.5 & 0.96 \\
\hline 6 & Do & 172 & 27.1 & 25 & 2 & 44.75 & 0.13 & 1 & 70.75 & 0.41 & 1 & 165.0 & 0.96 \\
\hline
\end{tabular}

\section{TABLE 36.-Wound respiration.}

Series I consisted of 8 mature joints of Opuntia versicolor, with a fresh weight of 120 grams, and was begun April 10 at $8 \mathrm{a} . \mathrm{m}$., and wounded at $10^{\mathrm{h}} 30^{\mathrm{m}} \mathrm{a} . \mathrm{m}$. Series II consisted of 7 joints of the same plant, with a fresh weight of 132 grams, and was begun at 2 p. m. April 10 and wounded at $7^{\mathrm{h}} 30^{\mathrm{m}} \mathrm{p}$. $\mathrm{m}$. The temperature throughout was $25^{\circ} \mathrm{C}$. After determination of normal respiration, wounding was effected by slicing the joints into sections 10 to $15 \mathrm{~mm}$. thick. The experiments were made at New York, April 10 to 12, 1912.

\begin{tabular}{|c|c|c|c|c|c|c|}
\hline & \multicolumn{2}{|r|}{ I. } & \multicolumn{2}{|r|}{ II. } & \multicolumn{2}{|c|}{ Average. } \\
\hline & $\begin{array}{c}\mathrm{CO}_{2} \text { per } \\
\text { gram- } \\
\text { hour. }\end{array}$ & $\begin{array}{c}\text { Acidity } \\
\text { juice } \\
\mathrm{N} / 10 \mathrm{KOH} \\
\text { per c.c. }\end{array}$ & $\begin{array}{l}\mathrm{CO}_{2} \text { per } \\
\text { gram- } \\
\text { hour. }\end{array}$ & $\begin{array}{c}\text { Acidity } \\
\text { juice } \\
\mathrm{N} / 10 \mathrm{KOH} \\
\text { per c.c. }\end{array}$ & $\begin{array}{c}\mathrm{CO}_{2} \text { per } \\
\text { gram- } \\
\text { hour. }\end{array}$ & $\begin{array}{c}\text { Acidity } \\
\text { juice } \\
\text { N / } 10 \mathrm{KOH} \\
\text { per c.c. }\end{array}$ \\
\hline Normal..... & $\left\{\begin{array}{l}m g . \\
0.24 \\
0.22\end{array}\right.$ & 0.94 & $\left\{\begin{array}{l}m g . \\
0.20 \\
0.23\end{array}\right.$ & 0.94 & $\left\{\begin{array}{l}m g . \\
0.22 \\
0.22\end{array}\right.$ & 0.94 \\
\hline $\begin{array}{l}\text { Wounded: } \\
\text { Time since } \\
\text { wounding, hrs. } \\
1 \ldots \ldots \\
2 \ldots \ldots \\
3 . \ldots .\end{array}$ & $\begin{array}{l}0.25 \\
0.27 \\
0.34\end{array}$ & 0.95 & $\begin{array}{l}0.21 \\
0.25 \\
0.36\end{array}$ & 0.92 & $\begin{array}{l}0.23 \\
0.26 \\
0.35\end{array}$ & 0.93 \\
\hline $\begin{array}{l}23 \ldots \ldots \ldots \\
24 \ldots \ldots \\
25 \ldots \ldots\end{array}$ & $\begin{array}{l}0.52 \\
0.51 \\
0.55\end{array}$ & 0.63 & $\begin{array}{l}0.49 \\
0.54 \\
0.47\end{array}$ & 0.58 & $\left\{\begin{array}{l}0.50 \\
0.51 \\
0.52\end{array}\right.$ & 0.60 \\
\hline $\begin{array}{l}48 \ldots \ldots \ldots \\
49 \ldots \ldots \ldots\end{array}$ & $\begin{array}{l}0.34 \\
0.31\end{array}$ & 0.68 & $\left\{\begin{array}{l}0.36 \\
0.36\end{array}\right.$ & 0.74 & $\left\{\begin{array}{l}0.35 \\
0.33\end{array}\right.$ & 0.71 \\
\hline
\end{tabular}


TABLE 37.-Wound respiration.

The normal respiration was first determined, and the plant then wounded by slicing joints into sections 10 to $15 \mathrm{~mm}$. thick. The determinations were made in New York with the Pettenkofer apparatus, the material being 8 joints of Opuntia versicolor having a fresh weight of $170 \mathrm{gm}$., sent from Tucson, Arizona. The date of the experiment was April 5 to 9, 1912.

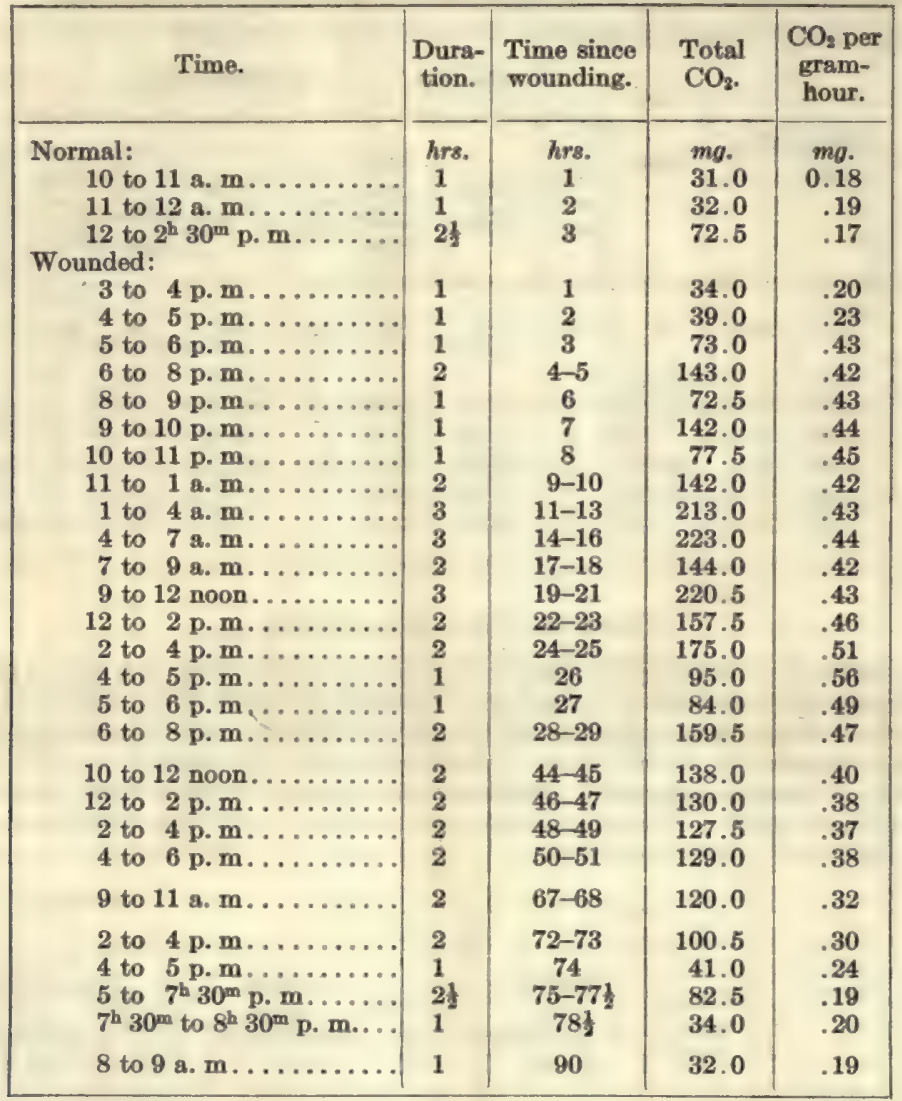


TABLE 38.-Intramolecular respiration after wounding, May 6, 1912.

The experiment was carried on in New York with material sent from Tucson, consisting of 15 joints of Opuntia versicolor, having a fresh weight of 320 grams. The normal respiration as determined the day before the experiment was 0.28 grams per hour. The specimens were wounded at 10 a. m. May 5 by slicing into sections 10 to $15 \mathrm{~mm}$. thick. Wound respiration was observed in air and in pure nitrogen at $20^{\circ}$ and $35^{\circ} \mathrm{C}$. The wound respiration would be somewhere near its maximum when the determinations began.

\begin{tabular}{|c|c|c|c|c|}
\hline Time. & $\begin{array}{l}\text { Dura- } \\
\text { tion. }\end{array}$ & Temp. & $\begin{array}{l}\text { Total } \\
\mathrm{CO}_{2}\end{array}$ & $\begin{array}{l}\mathrm{CO}_{2} \text { per } \\
\text { gram- } \\
\text { hour. }\end{array}$ \\
\hline 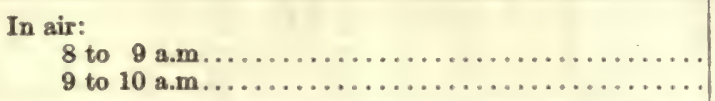 & $\begin{array}{c}\text { hrs. } \\
1 \\
1\end{array}$ & $\begin{array}{l}{ }^{\circ} \mathrm{C} . \\
20 \\
20\end{array}$ & $\begin{array}{l}m g . \\
227.00 \\
230.25\end{array}$ & $\begin{array}{l}m g . \\
0.70 \\
0.72\end{array}$ \\
\hline $\begin{array}{l}\text { In nitrogen from } 10 \text { a.m.; gas from receiver showed no } \\
\text { oxygen: }\end{array}$ & & & & \\
\hline 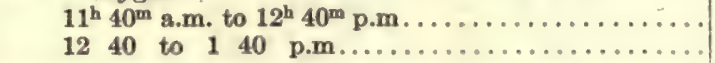 & $\begin{array}{l}1 \\
1\end{array}$ & $\begin{array}{l}20 \\
20\end{array}$ & $\begin{array}{l}60.00 \\
66.00\end{array}$ & $\begin{array}{l}0.19 \\
0.21\end{array}$ \\
\hline 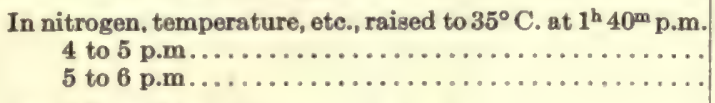 & $\begin{array}{l}1 \\
1\end{array}$ & $\begin{array}{l}35 \\
35\end{array}$ & $\begin{array}{l}140.50 \\
151.00\end{array}$ & $\begin{array}{l}0.44 \\
0.47\end{array}$ \\
\hline 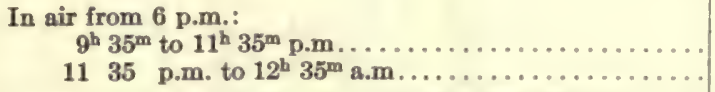 & $\begin{array}{l}1 \\
1\end{array}$ & $\begin{array}{l}35 \\
35\end{array}$ & $\begin{array}{l}352.10 \\
364.75\end{array}$ & $\begin{array}{l}1.10 \\
1.14\end{array}$ \\
\hline
\end{tabular}

TABLE 39.-Respiration with continuously changing temperature.

This determination was made at New York, January 29 and 30, 1912, in the dark, under temperature conditions simulating those of a normal spring day at Tucson. The material was sent from Tucson and consisted of 11 mature joints of Opuntia versicolor, having a fresh weight of 130 grams.

\begin{tabular}{|c|c|c|c|c|c|}
\hline & Time. & $\begin{array}{l}\text { Dura- } \\
\text { tion. }\end{array}$ & Temp. & $\begin{array}{l}\text { Total } \\
\mathrm{CO}_{2} .\end{array}$ & $\begin{array}{c}\mathrm{CO}_{2} \text { per } \\
\text { gram- } \\
\text { hour. }\end{array}$ \\
\hline \multirow{2}{*}{\multicolumn{2}{|c|}{$11^{\mathrm{h}} 45^{\mathrm{m}}$ a.m. to $3^{\mathrm{h}} 30^{\mathrm{m}}$ p.m. }} & nrs. & ${ }^{\circ} \mathrm{C}$. & $m g$. & $m g$. \\
\hline & & $3 \frac{3}{4}$ & 33 & 260 & 0.53 \\
\hline & to 630 p. m... & 3 & 30 & & .52 \\
\hline 630 & to $8 \mathrm{p} . \mathrm{m} \ldots \ldots$ & $1 \frac{1}{2}$ & 28 & 95.8 & .50 \\
\hline 8 to & 9 p. m............ & 1 & 27 & 63.3 & .49 \\
\hline 9 to & 10 p.m........ & 1 & 26 & 60.1 & .46 \\
\hline 10 to & 1 p. m....... & 1 & 24 & 56.1 & .43 \\
\hline 11 to & 12 midnight..... & 1 & 23 & 55.4 & .43 \\
\hline 12 to & 1 a.m....... & 1 & 21 & 52 & .40 \\
\hline 1 to & 2 a.m....... & 1 & 19 & 46.7 & .36 \\
\hline 2 to & 3 a.m....... & 1 & 17 & 40.5 & .31 \\
\hline 3 to & 4 a. m........ & 1 & 15 & 33.9 & .26 \\
\hline 4 to & 5 a. m....... & 1 & 14 & 28.6 & .22 \\
\hline 5 to & $3^{h} 30^{m}$ a. m..... & $1 \frac{1}{2}$ & 16 & 18 & .14 \\
\hline $6^{\mathrm{h}} 30$ & to $7^{\mathrm{h}} 30^{\mathrm{m}} \mathrm{a} . \mathrm{m}$. & 1 & 18 & 25 & .19 \\
\hline 730 & to 9 a. m...... & $1 \frac{1}{2}$ & 20 & 35.5 & .18 \\
\hline 9 to & 10 a. m......... & 1 & 23 & 41.7 & .32 \\
\hline 10 to & 11 a. $\mathrm{m} . . . .$. & 1 & 25 & 52.9 & .41 \\
\hline 11 to & 12 noon..... & 1 & 27 & 54 & .42 \\
\hline 12 to & 1 p.m......... & 1 & 28 & 56.2 & .43 \\
\hline 1 to & 2 p.m......... & 1 & 30 & 58.5 & .45 \\
\hline 2 to & 3 p. m.......... & 1 & 32 & 62 & .48 \\
\hline 3 to & 4 p. m......... & 1 & 35 & 71.3 & .55 \\
\hline 4 to & 5 p. m........... & 1 & 34 & 82 & .63 \\
\hline 5 to & 6 p.m......... & 1 & 32 & 69 & .53 \\
\hline 6 to & 8 p.m.... & 2 & 30 & 138 & .53 \\
\hline 8 to & 9 p. m...... & 1 & 27 & 61 & .47 \\
\hline
\end{tabular}


TABLE 40.-Respiration with continuously changing temperature.

The temperature variation is about that of an April day in Tucson. Determinations made in New York, March 22 and 23, 1912, the material being 15 mature joints of Opuntia versicolor of the previous season's growth, with a fresh weight of 180 grams, sent from Tucson.

\begin{tabular}{|c|c|c|c|c|}
\hline Time. & $\begin{array}{l}\text { Dura- } \\
\text { tion. }\end{array}$ & Temp. & $\begin{array}{l}\text { Total } \\
\mathrm{CO}_{2}\end{array}$ & $\begin{array}{c}\mathrm{CO}_{2} \text { per } \\
\text { gram- } \\
\text { hour. }\end{array}$ \\
\hline & hrs. & ${ }^{\circ} \mathrm{C}$. & $m g$. & $m g$. \\
\hline 6 to $7 \mathrm{p.} \mathrm{m} \ldots \ldots \ldots$ & 1 & 30 & 117.5 & 0.65 \\
\hline 7 to 9 p. m......... & 2 & 30 & 173.5 & .48 \\
\hline 9 to 10 p. m........ & 1 & 28 & 80.0 & .45 \\
\hline 10 to 11 p. m. . . . . . & 1 & 28 & 82 & .46 \\
\hline 11 to 12 midnight....... & 1 & 25.5 & 79 & .44 \\
\hline 12 to 1 a. $\mathbf{m} . . . \ldots \ldots$ & 1 & 23.5 & 62.5 & .35 \\
\hline 1 to $2 \mathrm{a} . \mathrm{m} \ldots \ldots \ldots$ & 1 & 20.5 & 54.5 & .30 \\
\hline 2 to 3 a. $\mathbf{m} \ldots \ldots \ldots$ & 1 & 20 & 40.5 & .22 \\
\hline 3 to $4 \mathrm{a} . \mathrm{m} \ldots \ldots \ldots$ & 1 & 18 & 36 & .20 \\
\hline 4 to 5 a. m........... & 1 & 16 & 32.5 & .18 \\
\hline 5 to $6 \mathrm{a} . \mathrm{m} \ldots \ldots \ldots$ & 1 & 14 & 34.5 & .19 \\
\hline 6 to $7^{\mathrm{h}} 30^{\mathrm{m}}$ a. $\mathrm{m} \ldots \ldots$ & $1 \frac{1}{2}$ & 16 & 39.5 & .15 \\
\hline $7^{\mathrm{b}} 30^{\mathrm{m}}$ to 9 a. m..... & $1 \frac{1}{2}$ & 18 & 44 & .16 \\
\hline 9 to 10 a. m........... & 1 & 21 & 44.5 & .25 \\
\hline 10 a. m. to $12^{\mathrm{h}} 15^{\mathrm{m}}$ p. $\mathrm{m}$. . & $2 \frac{1}{4}$ & 24 & 120 & .30 \\
\hline $12^{\mathrm{h}} 15^{\mathrm{m}}$ to 2 p. m....... & $1 \frac{3}{6}$ & 27 & 143.5 & .46 \\
\hline 2 to 3 p. m........... & 1 & 31 & 116 & .64 \\
\hline 3 to 4 p. m........... & 1 & 34 & 133 & .74 \\
\hline 4 to 5 p. m.......... & 1 & 33 & 191.5 & 1.06 \\
\hline 5 to 6 p. m........... & 1 & 31 & 127 & 0.71 \\
\hline 6 to 7 p. m......... & 1 & 29 & 100 & .55 \\
\hline 7 to $8^{\mathrm{h}} 30^{\mathrm{m}}$ p. $\mathrm{m} . . .$. & $1 \frac{\pi}{2}$ & 27 & 148 & .55 \\
\hline $8^{\mathrm{h}} 30^{\mathrm{m}}$ to 10 p. m..... & $1 \frac{1}{2}$ & 25 & 78 & .29 \\
\hline
\end{tabular}

TABLE 41.-Respiration with continuously changing temperature.

Made at New York, May 8 and 9, 1912, with material sent from Tucson. This material consisted of 18 mature joints of Opuntia versicolor of the previous season's growth, with a fresh weight of 354 grams. Previous to determination the plant was subjected to a temperature of $30^{\circ}$ for several hours.

\begin{tabular}{|c|c|c|c|c|}
\hline Time. & $\begin{array}{l}\text { Dura- } \\
\text { tion. }\end{array}$ & Temp. & $\begin{array}{l}\text { Total } \\
\mathrm{CO}_{2} .\end{array}$ & $\begin{array}{l}\mathrm{CO}_{2} \text { per } \\
\text { gram- } \\
\text { hour. }\end{array}$ \\
\hline 8 to $9 \mathrm{p}, \mathrm{m}$. & hrs. & ${ }^{\circ} \mathrm{C}$. & $\begin{array}{l}m g . \\
150\end{array}$ & $m g$. \\
\hline 9 to 10 p.m....... & 1 & 27 & 154 & .43 \\
\hline 10 to $11 \mathrm{pm} . \ldots \ldots$ & 1 & 25 & 133 & .38 \\
\hline 11 to 12 midnight...... & 1 & 23 & 107.5 & .30 \\
\hline 12 to 1 a. $\mathrm{m} . \ldots \ldots$ & 1 & 21.5 & 101.5 & .29 \\
\hline 1 to 2 a. $\mathbf{m} \ldots \ldots$ & 1 & 20 & 76 & .21 \\
\hline 2 to 3 a. $m \ldots \ldots$ & 1 & 18 & 69 & .20 \\
\hline 3 to 4 a. $\mathrm{m} \ldots \ldots$ & 1 & 17 & 52.5 & .15 \\
\hline 4 to $5^{\mathrm{h}} 10^{\mathrm{m}}$ a. m........ & $1 \frac{6}{6}$ & 16 & 52 & .13 \\
\hline $5^{\mathrm{h}} 10^{\mathrm{m}}$ to $5^{\mathrm{h}} 40^{\mathrm{m}}$ a. m. & & 12 & 17.5 & .10 \\
\hline $5^{\text {h }} 40^{\mathrm{m}}$ to 610 a. m.. & & 14 & 14 & .08 \\
\hline 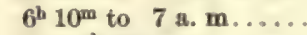 & 8 & 15 & 27.5 & .09 \\
\hline 7 to $8^{\mathrm{h}} 30^{\mathrm{m}}$ a. m........ & 1 ) & 16 & 84 & .16 \\
\hline $8^{\mathrm{h}} 30^{\mathrm{m}}$ to $10 \mathrm{a} . \mathrm{m} \ldots$ & $1 \frac{1}{8}$ & 20 & 116 & .22 \\
\hline 10 to 11 a. m........ & 1 & 21 & 81 & .23 \\
\hline 11 to 12 noon......... & 1 & 22.5 & 88.5 & .25 \\
\hline 12 to 1 p. m......... & 1 & 24 & 133 & .38 \\
\hline 1 to 2 p. m.......... & 1 & 27 & 161.5 & .46 \\
\hline 2 to 3 p. m........... & 1 & 30 & 183 & .52 \\
\hline 3 to 4 p. m.......... & 1 & 33 & 193.5 & .55 \\
\hline 4 to $4^{\mathrm{h}} 30^{\mathrm{m}}$ p. m........ & $\frac{1}{2}$ & 34.5 & 132 & .75 \\
\hline $4^{\mathrm{h}} 30^{\mathrm{m}}$ to 5 p. $\mathrm{m} . \ldots \ldots$ & & 33 & 170 & .96 \\
\hline 5 to $5^{\mathrm{h}} 30^{\mathrm{m}}$ p. m......... & & 32 & 145 & .82 \\
\hline $5^{\mathrm{h}} 30^{\mathrm{m}}$ to 6 p. m....... & $\frac{i}{2}$ & 31 & 111 & .63 \\
\hline 6 to $8 \mathrm{pm} . . . \ldots \ldots$ & 2 & 29 & 314 & .44 \\
\hline 8 to 9 p. m....... & 1 & 27 & 142 & .40 \\
\hline
\end{tabular}




\section{GAS INTERCHANGE. ${ }^{a}$}

\section{GENERAL CONSIDERATIONS.}

The problem presented in the study of the interchange of carbon dioxide and oxygen and the $\frac{\mathrm{CO}_{2}}{\mathrm{O}_{2}}$ quotient, particularly in relation to the acidity conditions, is a complex one and some preliminary considerations are necessary before any detailed discussion is attempted.

Attention has been called to the fact that acidity and the rate of respiration are very greatly influenced by the age and condition of the tissues. The former is highest and the latter most rapid in the young joints, which are, of course, highly turgid. Other things being equal, the acidity is lower and the respiration somewhat less in amount in the mature joints that are turgid, which is the condition ordinarily presented in the winter and summer rainy seasons. In the mature joints which are flaccid, by reason of the loss of water in the dry seasons, both the acidity and evolution of carbon dioxide are at their minimum. The distinguishing of these three conditions of the plant, the young, the mature-turgid, and the mature-flaccid, becomes of especial importance. It is, of course, obvious that there can be no sharp line between these stages so far as the life of any one individual is concerned; but in the actual conditions presented by the plants at the time of year when most of these experiments were carried on, the three classes of tissue were sharply enough marked. A study of the transitional stages in the physiological activity would, no doubt, be of considerable interest, although in this work no definite attempt was made in this direction; but, as will be shown later, the examination of the data revealed certain instances of intermediate conditions. For example, in many of the experiments on the mature joints which were carried on during the summer of 1913, except those which were made from especially irrigated plants, it was found, when the dry weights of the specimens were determined, that they were essentially in the flaccid class, despite the fact that some of them were putting forth new growth. It was also found that this new growth, though in many respects in the typical young condition, was by no means as high in water-content as the joints obtained from plants more liberally supplied with water.

The basis of separation for purposes of discussion and classification is made, then, on three conditions of the tissue, determined in the main by the percentage of dry weight, although other characters occasionally have influenced the decision into which group the material should be assigned. The young joints, with the exception of those referred to above, averaged in these experiments between 15 and 17 per cent of dry substance; the mature-turgid joints from 18 to 20 per cent, while those which were flaccid were all over 25 per cent, running up in some cases to as much as 35 per cent of dry weight.

The young joints are undoubtedly the most active in respiration, and probably also the most active in photosynthesis, but they are not necessarily the most important part of the plant as far as nutrition is concerned. To begin with, the actual amount of young growth in proportion to the mature is relatively small, even in a plant which is growing rapidly, and it is not probable that it keeps up its increased activity beyond the beginning of the dry after-

${ }^{a}$ This portion of the work was done in collaboration with Miss M. E. Latham. 
summer, following the summer rainy season during which it was produced. The really essential part of the active tissue must be comprised in the mature joints when they are turgid, a condition realized during the rainy seasons, which are characteristic of the region around Tueson, and for a time subsequent to these periods. During the winter rains there will not be any of the young joints in the case of Opuntia versicolor, since these are formed almost exclusively in the summer. As will be seen later, the winter and spring seasons must be a highly important period for this species of cactus, if not also for others, for it seems that the bulk of the actual storing of potential energy must take place during the bright days in the winter and the warmer but still relatively cool days of the spring. The condition presented by the flaccid joints does not, it seems, inhibit their activity, for while they are relatively quiescent the gas interchange is by no means non-existent. Whether they carry on much photosynthetic work is perhaps a question, for in appearance, at least, the chlorophyll is certainly less in evidence than when the plants are turgid. Not a small portion of the year, however, is spent in a desiccated condition by the smaller cacti, which do not store the enormous quantities of water found in the more bulky forms.

It has not been possible to trace the gradual transition from the turgid to the flaccid condition, for neither of the writers has been in Tucson at the proper time of year, which would be in May and June or from late August to October. But the assumption of a turgid condition from the flaccid state is very easy of accomplishment. In as short a period as 5 days, a plant which was copiously irrigated in 1913 increased its water-content from about 66 per cent to 79 per cent, or, in other words, its dry weight fell from 33 to 21 per cent. By further irrigation for about two weeks the dry weight fell to about 17 per cent. In the summer, after the rains have commenced, it is safe to say that within a week the plants are practically fully turgid and active.

As a matter of practical experimentation it was easily possible in the summer of 1912 to carry on simultaneous determinations with flaccid, turgid, and young joints. Certain plants in the neighborhood of an irrigated area were already in full activity and had put forth a quantity of young shoots by the middle of June. At the same time the plants in their natural condition, removed from any source of water, were wholly flaccid. Not one showed signs of producing young joints.

The condition in 1913 was somewhat different. The winter had been an exceptionally cold one, indeed almost a record for the region, and a great deal of winter-killing had taken place; also, there had been a shortage of rain during the winter months. Despite the latter circumstance and perhaps because the actual mass of the plant had been so greatly diminished by the parts lost by freezing, plants wholly removed from any source of irrigation had put forth new shoots, although the mature joints were shriveled and dry. There could be no mistake that these shoots were new growth, for they were all provided with leaves. They showed a dry weight of about 20 per cent, which is considerably greater than that usually found in young tissue, which it will be remembered is about 15 per cent. Indeed, the dry weight of these joints closely approximated that which had been determined in the previous summer as the average for the mature-turgid joints. Nevertheless they behaved essentially as young joints are wont to and were putting forth an 
abundance of leaves. Their acidity, it is true, was usually lower than that of young material from more turgid plants, with the consequential effect on their $\frac{\mathrm{CO}_{2}}{\mathrm{O}_{2}}$ ratio. In a measure they constituted a condition intermediate between the young and the old stems.

Thus it will be seen that there must be expected a very considerable variation in the condition and consequent behavior of cacti from season to season and, indeed, as experience has shown between different plants in the same season. It becomes imperative, therefore, to have a large number of experiments in order to establish any kind of a reliable average, a fact that is additionally true in the case of such physiological processes as those involved in gas interchange, which are also so greatly influenced by relatively small changes in the external conditions. The attempt has been made to accumulate a considerable body of data, which, while relatively large, would no doubt be more satisfactory if doubled.

Not every one of the experiments carried out has been incorporated in the account given here. As has been said in the chapter on experimental methods, all experiments were thrown out in which the analysis showed that more than 5 per cent carbon dioxide was accumulated, with the exception of a few selected ones, retained for special reasons and so indicated. For various causes a number of other experiments were also neglected, especially in the beginning, but none has been abandoned except for well-defined and cogent reasons which rendered their results untrustworthy.

In connection with the conditions of dryness and turgidity, it is interesting to note a possible relation of the color of the plant. In almost all cases record was made of the color of the exterior of the joint, which varies from the typical somewhat bluish green to a reddish tint that shades to a yellow brown in the grooves and on the under side of the joint. When these notes were compared with the results of the acidity determinations and the gas interchange it did not develop that there was any very definite or marked relation to be found between them. In a general way, the drier the plants are the more likely is their color to be red, but except in so far as the dry condition affects both their acidity and rate of gas interchange, which is lower in each case, there is no close correlation. For instance, in those cases where the mature and also turgid joints were red-which while not common is also not infrequent-there appeared no regularity as to a greater or lesser quantity of acid or to an increased or decreased $\frac{\mathrm{CO}_{2}}{\mathrm{O}_{2}}$ quotient. The young joints also showed a reddish tinge at times, notably those mentioned as having been used in the summer of 1913 , but except for their somewhat lower activity there was no effect to be correlated with color.

However, it is probable that redness of color is generally associated with loss of water by the tissues. It would be interesting to investigate this point, as the formation of anthocyan in chlorophyll-bearing tissue is usually held to be correlated with low temperatures. Of course, one effect of cold is to deprive the plant of water and the question may be asked whether desiccation due to whatever circumstance is not a predisposing cause for the formation of anthocyan compounds. From observations made, which were necessarily incomplete, it seems improbable that the reddening of the Opuntia versicolor joints is connected with the lower winter temperatures, for in March and April, 
according to the notes kept, the highly colored plants seem to have been much less frequent than in late June and early July. A continuous series of observations during the seasonal changes would be of considerable interest in throwing light on this question as well as for determining, what very well may be the case, whether there is any individual predisposition on the part of certain plants to form and to retain a reddish color more or less permanently. The red is not exclusively limited to the flaccid plants. It will be remembered in this connection that the flowers of Opuntia versicolor exhibit a considerable range of color, but no satisfactory evidence was forthcoming that any particular color in the flower characterized plants with red color present or absent in the stem.

\section{QUANTITIES IN GAS INTERCHANGE.}

An inspection of the results set forth in table 42 indicates the same difference in the activity of the plants, according to their age and condition, that was seen in the results of the Pettenkofer experiments. They also show that there is a great variation in the volumes of the gases which are given off and absorbed. This, as will be shown in the subsequent discussion, is to a large extent dependent upon the temperature and increasing or decreasing acidity.

In the study of the complete gas interchange we have, of course, to consider not only the carbon dioxide evolved, but also the oxygen absorbed. The former does not vary alone, but with the latter, although not always in the same degree. Consequently, under changing conditions there may be an alteration in the $\frac{\mathrm{CO}_{2}}{\mathrm{O}_{2}}$ quotient. We have here attempted to trace these changes and to find how the gas-interchange ratio is related to both the external and internal conditions.

Before discussing the details it is well to consider the general rate of gas interchange in relation to the fundamental question of the age and state of the tissues. Table 42 gives the general averages of the whole series of gas-interchange experiments in which the external conditions, except temperature, are relatively constant. All of these experiments were in normal air and in the dark. No account has been taken of the individual $\frac{\mathrm{CO}_{2}}{\mathrm{O}_{2}}$ ratios or acidities in these averages, but the results have been arranged in three (in one case four) temperature groups. The average gas-interchange ratio has been given for each group, but does not have great significance, save to show in a very general way the gross average $\frac{\mathrm{CO}_{2}}{\mathrm{O}_{2}}$ quotient. The amounts of gases exhaled and absorbed are given in terms of both fresh and dry weights of the plant substance.

Attention is again called to the fact that in this section of this paper all quantities of carbon dioxide and oxygen are expressed in cubic centimeters unless it is specifically stated otherwise. The acidities are given in terms of cubic centimeters of decinormal alkali per cubic centimeter of juice or per gram fresh or dry weight.

For the same amount of dry substance the young joints respire at a rate about three times that of the flaccid ones and twice that of the turgid plants. The relative quantities of carbon dioxide evolved and oxygen absorbed are essentially the same in the young and the turgid material, at the temperatures from 31 to $36^{\circ} \mathrm{C}$., so that their $\frac{\mathrm{CO}_{2}}{\mathrm{O}_{2}}$ ratios are similar. In the $40^{\circ}$ to $41^{\circ} \mathrm{C}$. 
temperature group among the experiments on turgid joints the ratio rises very greatly. With flaccid joints there is a general tendency to have a great oxygen absorption, which shows also in the averages, so that the gas ratio is necessarily lower. Attention should be called, however, to the fact that no conclusions should be drawn from this table as to the relation of temperature and the $\frac{\mathrm{CO}_{2}}{\mathrm{O}_{2}}$ quotient, since neither the amount nor the course of the various acidities have been taken into account in making these averages. It will develop, from the more specific analysis of the results which is to follow, that these considerations are of no small importance. The purpose of this table is to indicate in a general way the difference in activity of the three classes of tissues.

TABLE 42.-Evolution of $\mathrm{CO}_{2}$ and absorption of $\mathrm{O}_{2}$ in relation to temperatures.

Evolution of $\mathrm{CO}_{2}$ and absorption of $\mathrm{O}_{2}$ in relation to temperature, arranged without regard to the $\frac{\mathrm{CO}_{2}}{\mathrm{O}_{2}}$ ratios; averages of 104 gas-interchange experiments, made during the summers of 1912 and 1913.

\begin{tabular}{|c|c|c|c|c|c|c|c|}
\hline & Temperature. & $\begin{array}{c}\text { No. } \\
\text { of } \\
\text { expts. } \\
\text { aver- } \\
\text { aged. }\end{array}$ & $\begin{array}{c}\mathrm{CO}_{2} / \mathrm{O}_{2} \\
\text { ratio. }\end{array}$ & $\begin{array}{c}\mathrm{CO}_{2} \\
\text { evolved } \\
\text { per gma } \\
\text { per hr., } \\
\text { fresh } \\
\text { weight. }\end{array}$ & $\begin{array}{c}\mathrm{O}_{2} \mathrm{ab}- \\
\text { sorbed } \\
\text { per } \mathrm{gm} . \\
\text { per } \mathrm{hr} . \\
\text { fresh } \\
\text { weight. }\end{array}$ & $\begin{array}{c}\mathrm{CO}_{2} \\
\text { evolved } \\
\text { per gm. } \\
\text { per hr., } \\
\text { dry } \\
\text { weight. }\end{array}$ & $\begin{array}{c}\mathrm{O}_{2} \text { ab- } \\
\text { sorbed } \\
\text { per gm. } \\
\text { per hr., } \\
\text { dry } \\
\text { weight. }\end{array}$ \\
\hline $\begin{array}{l}\text { Mature-turgid; average per } \\
\text { cent, dry weight, } 20.8 \ldots\end{array}$ & $\begin{array}{c}{ }^{\circ} C . \\
\text { Below } 30 \ldots \\
31 \text { to } 33 \ldots \\
34 \text { to } 36 \ldots \\
40 \text { to } 41 \ldots\end{array}$ & $\begin{array}{r}24 \\
8 \\
7 \\
4\end{array}$ & $\begin{array}{l}0.72 \\
0.74 \\
0.74 \\
1.12\end{array}$ & $\begin{array}{l}0.087 \\
0.100 \\
0.140 \\
0.340\end{array}$ & $\begin{array}{l}0.123 \\
0.136 \\
0.190 \\
0.303\end{array}$ & $\begin{array}{l}0.472 \\
0.490 \\
0.710 \\
1.545\end{array}$ & $\begin{array}{l}0.651 \\
0.662 \\
0.960 \\
1.381\end{array}$ \\
\hline $\begin{array}{l}\text { Mature-flaccid; average per } \\
\text { cent, dry weight, } 30.7 \ldots\end{array}$ & $\left\{\begin{array}{l}\text { Below } 30 \ldots \\
31 \text { to } 33 \ldots \\
34 \text { to } 36 \ldots\end{array}\right.$ & $\begin{array}{r}7 \\
11 \\
6\end{array}$ & $\begin{array}{l}0.52 \\
0.64 \\
0.68\end{array}$ & $\begin{array}{l}0.068 \\
0.115 \\
0.140\end{array}$ & $\begin{array}{l}0.130 \\
0.176 \\
0.206\end{array}$ & $\begin{array}{l}0.220 \\
0.385 \\
0.441\end{array}$ & $\begin{array}{l}0.425 \\
0.598 \\
0.648\end{array}$ \\
\hline $\begin{array}{l}\text { Young; average per cent, } \\
\text { dry weight, 16.4 ...... }\end{array}$ & $\left\{\begin{array}{l}\text { Below } 30 \ldots \\
31 \text { to } 33 \ldots \\
34 \text { to } 36 \ldots\end{array}\right.$ & $\begin{array}{r}14 \\
18 \\
5\end{array}$ & $\begin{array}{l}0.65 \\
0.74 \\
0.70\end{array}$ & $\begin{array}{l}0.131 \\
0.230 \\
0.226\end{array}$ & $\begin{array}{l}0.200 \\
0.310 \\
0.324\end{array}$ & $\begin{array}{l}0.739 \\
1.444 \\
1.303\end{array}$ & $\begin{array}{l}1.124 \\
1.946 \\
1.854\end{array}$ \\
\hline
\end{tabular}

The amount of carbon dioxide given off is not as much as that formed by the typical plant, but the disparity is by no means as great as would be supposed from the statements that are usually made. Indeed, in the young tissue the evolution of carbon dioxide is decidedly rapid. In order better to make comparisons it is well to estimate the results by weight rather than by volume. Reducing those given in table 42 , where the quantities of carbon dioxide are expressed in cubic centimeters, by multiplying by the appropriate factor for the weight of the gas at different temperatures and at the barometric pressure for Tucson (see description of methods), we have (in table 43) the amounts in terms of milligrams per gram tissue per hour. The amounts are in as close agreement with the results indicated by the Pettenkofer method as would be expected and as may be seen by reference to table 28 , on page 55. The young tissue at $31^{\circ}$ to $36^{\circ} \mathrm{C}$. loses in 24 hours approximately 0.8 per cent of its fresh weight or 4.5 per cent of its dry weight in carbon dioxide. At the same temperatures, the old turgid joints show a loss of about half that amount in their fresh weight, but less than a third when reckoned for dry weight. At $40^{\circ}$ to $41^{\circ} \mathrm{C}$. their activity is somewhat greater 
TABLE 43.

\begin{tabular}{|c|c|c|c|c|c|}
\hline Age and condition. & Temperature. & $\begin{array}{l}\mathrm{CO}_{2} \text { per } \\
\text { gram- } \\
\text { hour, } \\
\text { fresh } \\
\text { weight. }\end{array}$ & $\begin{array}{c}\text { Loss } \mathrm{CO}_{2} \\
\text { per } 24 \\
\text { hours, } \\
\text { fresh } \\
\text { weight. }\end{array}$ & $\begin{array}{l}\mathrm{CO}_{2} \text { per } \\
\text { gram- } \\
\text { hour, } \\
\text { dry } \\
\text { weight. }\end{array}$ & $\begin{array}{c}\text { Loss } \mathrm{CO}_{2} \\
\text { per } 24 \\
\text { hours, } \\
\text { dry } \\
\text { weight. }\end{array}$ \\
\hline Mature-turgid. . & $\left\{\begin{array}{c}{ }^{\circ} \mathrm{C} . \\
31 \text { to } 33 \ldots \ldots \\
34 \text { to } 36 \ldots \ldots \\
40 \text { to } 41 \ldots \ldots\end{array}\right.$ & $\begin{array}{l}m g . \\
0.13 \\
0.14 \\
0.19 \\
0.42\end{array}$ & $\begin{array}{l}\text { p.ct. } \\
0.3 \\
0.3 \\
0.5 \\
1.0\end{array}$ & $\begin{array}{l}m g . \\
0.71 \\
0.68 \\
0.96 \\
0.93\end{array}$ & $\begin{array}{l}\text { p. ct. } \\
1.7 \\
1.6 \\
2.3 \\
4.6\end{array}$ \\
\hline Mature-flaccid. . & $\left\{\begin{array}{l}\text { Below } 30 \ldots \\
31 \text { to } 33 \ldots \\
34 \text { to } 36 \ldots\end{array}\right.$ & $\begin{array}{l}0.10 \\
0.16 \\
0.19\end{array}$ & $\begin{array}{l}0.2 \\
0.4 \\
0.5\end{array}$ & $\begin{array}{l}0.33 \\
0.53 \\
0.60\end{array}$ & $\begin{array}{l}0.8 \\
1.3 \\
1.4\end{array}$ \\
\hline Young.... & $\left\{\begin{array}{l}\text { Below } 30 \ldots \\
31 \text { to } 33 \ldots \\
34 \text { to } 36 \ldots\end{array}\right.$ & $\begin{array}{l}0.20 \\
0.32 \\
0.31\end{array}$ & $\begin{array}{l}0.5 \\
0.8 \\
0.7\end{array}$ & $\begin{array}{l}1.11 \\
2.00 \\
1.77\end{array}$ & $\begin{array}{l}2.7 \\
4.8 \\
4.2\end{array}$ \\
\hline
\end{tabular}

than that of the young plant at $31^{\circ}$ to $36^{\circ} \mathrm{C}$. The flaceid joints at the latter temperature lose about the same percentage of their fresh weight as do the turgid ones, but their dry-weight loss is considerably less.

For comparison with these figures it is interesting similarly to calculate a few of the results given by Aubert both of cacti and of some other plants that are more typical. In two cactus forms, Opuntia tomentosa and Mamillaria newmanniana, he finds the loss is respectively 0.14 and 0.08 per cent in a 24-hour period. In plants which are not succulents the following figures for the loss in weight by the evolution of carbon dioxide, for a similar period, may be given: Ricinus, 0.08 per cent; Hedera, 0.9 per cent; Triticum, 1.1 per cent. In this connection it may be well to call attention to a mistake which has crept into the citations of the figures from which these calculations have been made. Aubert's own results are given in cubic millimeters per hour, but they have been cited as cubic centimeters ${ }^{a}$. Comparison of Aubert's results with our own indicate that the Opuntia versicolor was far more active than either of the two cacti mentioned above. The evolution of carbon dioxide at $31^{\circ}$ to $33^{\circ} \mathrm{C}$. was equal to that of Ricinus at $20^{\circ} \mathrm{C}$. and not so very much less than that of Triticum at $13^{\circ} \mathrm{C}$. Since from $31^{\circ}$ to $36^{\circ} \mathrm{C}$. may be taken as the normal temperature for these cacti in the summertime in their native habitat, it would appear that under their natural conditions and in their normal state of activity cacti are by no means as torpid in regard to the evolution of carbon dioxide as is commonly supposed.

\section{TEMPERATURE EFFECT.}

For the study of the effect of temperature alone upon the rate and especially the ratio of gas interchange, it is most instructive to take a group of data in which the acidity conditions are similar. Such a one is the series under discussion. In these experiments which were carried on in New York under the equable conditions of the laboratory, not only was the acidity of the samples

${ }^{a}$ Pfeffer, W. Physiology of plants. (Translated by Ewart.) Vol. I, p. 525, 1904. The citation in the original German edition is correct. See also Czapek, F., Biochemie der Pfianzen, vol. II, p. 382, 1905. 
closely similar, but the actual amount of acid present was less fluctuating (table 53). Four series were carried on simultaneously and at three temperatures, namely, $15^{\circ}, 25^{\circ}, 40^{\circ} \mathrm{C}$. Expressed in cubic centimeters per gram-hour fresh weight, the averages of the series are shown.

It will be seen that the ratio rises with the temperature or, in other words, the production of earbon dioxide increases more rapidly than does the absorption of oxygen. This is in agreement with the results of Aubert.

It is interesting to note in this connection the acceleration of interchange of gases in comparison with that of other ehemical reactions. The doubling of rate called for by the ordinarily accepted idea of van't Hoff's statement regarding reaction velocities is not attained, but, as Barry ${ }^{a}$ has said, many circumstances may condition the speed of reactions in such complicated physiological processes. At $25^{\circ}$ the amount of carbon dioxide produced is 83 per cent higher than at $15^{\circ}$, while at $40^{\circ}$, where an increase of the original rate of 600 per cent would be predicted, there is an actual increase of 550 per cent. On the other hand, there are individual experiments in which the difference

TABLE 44.

\begin{tabular}{|c|c|c|c|}
\hline Temp. & $\mathrm{CO}_{2}$ evolved. & $\mathrm{O}_{2}$ absorbed. & Ratio $\mathrm{CO}_{2} / \mathrm{O}_{2}$ \\
\hline${ }^{\circ}{ }_{C .}$ & & & \\
15 & $0 . c$. & $c . c$. & \\
25 & 0.076 & 0.164 & 0.46 \\
40 & 0.420 & 0.216 & 0.64 \\
& & 0.523 & 0.80 \\
\hline
\end{tabular}

between the rates at $15^{\circ} \mathrm{C}$. and $25^{\circ} \mathrm{C}$. is almost exactly 100 per cent. In one case the evolution of carbon dioxide at $15^{\circ} \mathrm{C}$. is 0.066 c.c. per gram-hour and at $25^{\circ} \mathrm{C}$. it is 0.134 c.c. for the same unit. In another case the figures at $15^{\circ} \mathrm{C}$. and $40^{\circ} \mathrm{C}$. are 0.075 c.c. and 0.45 c.c., respectively, which is an increase of exactly 600 per cent.

It is obvious since the $\frac{\mathrm{CO}_{2}}{\mathrm{O}_{2}}$ ratio rises, that the reactions involved in the absorption of oxygen from the air do not keep pace with those concerned in the production of carbon dioxide. The amount of oxygen taken in at $25^{\circ} \mathrm{C}$. is only 32 per cent more than at $15^{\circ} \mathrm{C}$., while at $40^{\circ} \mathrm{C}$. it has risen only to 220 per cent. It would, however, be unsafe to say that the actual oxidation does not proceed in something like geometrical ratio with rising temperature, for at higher temperatures it is not impossible that some of the necessary oxygen is supplied, as it is in intramolecular respiration.

In connection with the discussion of temperature effects, it is well to turn back to an examination of the general mass of determinations from the standpoint of increased carbon dioxide formation. In comparing the group of experiments carried on at $23^{\circ}$ to $24^{\circ} \mathrm{C}$. with those which were made at $33^{\circ}$ to $34^{\circ} \mathrm{C}$., approximately the same increase is noted as above described, irrespective of acidity or other consideration. However, as has been pointed out, the $\frac{\mathrm{CO}_{2}}{\mathrm{O}_{2}}$ ratio is greatly affected by the degree of the acidity, so that it is evi-

${ }^{a_{B}}$ Barry, F. The influence of temperature on chemical reaction in general. Amer. Journ. of Bot., vol. I, pp. 203-225, 1914. 
dent that the absorption of oxygen, rather than the evolution of carbon dioxide, is influenced. The effect of temperature change on the activity of young joints is brought out in experiments $39,39 a, b$, and $c$ (table 60). The first two were carried on at $24^{\circ} \mathrm{C}$, , the others at $34^{\circ} \mathrm{C}$. In this case the identical material was used in all four experiments. The averages are given in table 45 .

TABLE 45.

\begin{tabular}{|c|c|c|c|c|c|c|c|}
\hline \multirow[t]{2}{*}{ Experiment. } & \multirow[t]{2}{*}{ Temp. } & \multirow{2}{*}{$\begin{array}{l}\mathrm{CO}_{2} \text { per } \\
\text { gram- } \\
\text { hcur, } \\
\text { fresh. }\end{array}$} & \multirow{2}{*}{$\begin{array}{l}\mathrm{O}_{2} \text { per } \\
\text { gram- } \\
\text { hour, } \\
\text { Fresh. }\end{array}$} & \multirow{2}{*}{$\begin{array}{l}\mathrm{CO}_{2} \text { per } \\
\text { gram- } \\
\text { hour, } \\
\text { dry. }\end{array}$} & \multirow{2}{*}{$\begin{array}{l}\mathrm{O}_{2} \text { per } \\
\text { gram } \\
\text { hour, } \\
\text { dry. }\end{array}$} & \multicolumn{2}{|c|}{$\begin{array}{l}\text { Acidity per gram } \\
\text { dry weight, in } \\
\mathrm{N} / 10 \mathrm{KOH} \text {. }\end{array}$} \\
\hline & & & & & & Initial. & Final. \\
\hline $\begin{array}{l}39,39 a \ldots \\
39 b, 39 c \ldots\end{array}$ & $\begin{array}{l}{ }^{\circ} C . \\
24 \\
34\end{array}$ & $\begin{array}{l}m g . \\
0.155 \\
0.332\end{array}$ & $\begin{array}{l}m g . \\
0.186 \\
0.365\end{array}$ & $\begin{array}{l}m g . \\
0.809 \\
1.755\end{array}$ & $\begin{array}{l}m g . \\
0.971 \\
1.933\end{array}$ & $\begin{array}{l}\text { e.c. } \\
6.78\end{array}$ & $\begin{array}{l}\text { c.c. } \\
4.40\end{array}$ \\
\hline
\end{tabular}

The $\frac{\mathrm{CO}_{2}}{\mathrm{O}_{2}}$ quotient rose during the experiments from 0.83 to 0.90 , but it is not that point which is of present concern. There would normally be a rising ratio with falling acidity, which is perhaps accentuated in this case by the rising temperature as well. As for the amount of carbon dioxide given off, there is an increase of over 100 per cent at the higher as compared with the lower temperature.

While, as has been shown in the pages on acidity, increase of temperature is accompanied by decrease in acid-content, it is not to be expected that the averages taken from the whole mass of miscellaneous experiments, the material for which was collected under varying circumstances and from plants of very diverse acidity, would give any decisive evidence in this direction. A high acidity which is falling will give a relatively high ratio between the oxygen and carbon dioxide, irrespective of temperature, while the reverse is true with a low acidity that is rising. Thus, while temperature influences the ratio it is not so important a factor as is the acidity or the age or condition of the material.

By selecting a series with a fairly limited range of acidity the temperature effect on the $\frac{\mathrm{CO}_{2}}{\mathrm{O}_{2}}$ ratio becomes apparent. Taking from the experiments with mature-turgid joints the ratios in which the material showed an acidity value ranging between 1.01 and 2.00 c.c. and also those between 3.01 and 4.00 c.c., $\mathrm{N} / 10 \mathrm{KOH}$ per gram dry weight, the results are as follows:

TABLE 46.

\begin{tabular}{|c|c|c|}
\hline Acidity value. & Temp. & $\begin{array}{c}\mathrm{CO}_{2} / \mathrm{O}_{2} \\
\text { ratio. }\end{array}$ \\
\hline Between 1.01 and 2.00 c.c....... & ${ }^{\circ}{ }^{C .}$ & \\
24 & 0.61 \\
30 & 0.66 \\
36 & 0.77 \\
42 & 1.32 \\
& & 0.94 \\
23 & 0.94 \\
28 & 0.98 \\
33 & \\
42 & 1.12 \\
\hline
\end{tabular}


The number of experiments is not large enough to select very complete series, but they show agreement with the special temperature series already considered.

This matter has been discussed at some length, since, in the tables which follow, the experiments have been arranged on the basis of gas-interchange ratios and only secondarily according to temperature, so that owing to individual variation the real temperature effects are sometimes masked.

In summing up the effect of temperature on the respiratory gas interchange it may be said that the amount of earbon dioxide given off rises measurably in accord with the van't Hoff generalization regarding reaction velocities, while the increase of absorption of oxygen is somewhat less. As a consequence, the $\frac{\mathrm{CO}_{2}}{\mathrm{O}_{3}}$ quotient tends to rise with ascending temperatures.

\section{GAS INTERCHANGE RATIO AND ACIDITY.}

When the whole mass of experiments made during the summers of 1912 and 1913 from material in its natural habitat is arranged according to the gasinterchange ratio, quite irrespective of whether the material was young or old, turgid or flaccid, and without regard to temperatures, we get the general averages given in table 47.

TABLE 47.-General average of 104 gas-interchange determinations urith accompanying acidities arranged without regard to temperature, but grouped under the $\mathrm{CO}_{2} / \mathrm{O}_{2}$ ratios.

\begin{tabular}{|c|c|c|c|c|c|}
\hline $\begin{array}{l}\text { No. of } \\
\text { expts } \\
\text { aver- } \\
\text { aged. }\end{array}$ & $\mathrm{CO}_{2} / \mathrm{O}_{2}$ ratio. & $\begin{array}{c}\text { Aetual } \\
\text { average of } \\
\mathrm{CO}_{2} / \mathrm{O}_{2} \\
\text { ratios. }\end{array}$ & $\begin{array}{c}\text { Acidity } \\
\text { juice, } \\
\text { per e.c. } \\
\text { N/10 KOH }\end{array}$ & $\begin{array}{c}\text { Total } \\
\text { acidity } \\
\text { N / } 10 \mathrm{KOH} \\
\text { per gram, } \\
\text { fresh } \\
\text { weight. }\end{array}$ & $\begin{array}{c}\text { Total } \\
\text { acidity } \\
\text { N / } 10 \mathrm{KOH} \\
\text { per gram, } \\
\text { dry weight. }\end{array}$ \\
\hline $\begin{array}{r}2 \\
17 \\
14 \\
16 \\
17 \\
22 \\
16\end{array}$ & $\begin{array}{l}\text { Below } 0.40 \ldots \\
0.41 \text { to } 0.50 \ldots \\
0.51 \text { to } 0.60 \ldots \\
0.61 \text { to } 0.70 \ldots \\
0.71 \text { to } 0.80 \ldots \\
0.81 \text { to } 0.90 \ldots \ldots \\
0.91+\ldots \ldots\end{array}$ & $\begin{array}{l}0.33 \\
0.46 \\
0.56 \\
0.67 \\
0.75 \\
0.86 \\
1.08\end{array}$ & $\begin{array}{l}c . c . \\
0.28 \\
0.47 \\
0.64 \\
0.71 \\
0.88 \\
1.45 \\
1.53\end{array}$ & $\begin{array}{l}c . c . \\
0.14 \\
0.23 \\
0.34 \\
0.44 \\
0.50 \\
0.94 \\
0.90\end{array}$ & $\begin{array}{l}c . c . \\
0.58 \\
r .97 \\
1.50 \\
2.22 \\
2.75 \\
4.68 \\
4.63\end{array}$ \\
\hline
\end{tabular}

With rising ratio there is rising acidity until, when the acidity is highest, the gas-interchange quotient is slightly more than unity. In other words, the evolution of carbon dioxide is a little in excess of the absorption of oxygen. At the other end of the scale, where the acidity is lowest, the average evolution of the former was only one-third of the absorption of the latter. In individual experiments there is, of course, considerable variation. Experiment 32 (table 60 ) showed an initial acidity of 2.32 for the pure juice, which was the highest obtained, and of 5.75 per gram dry weight, giving as its average ratio almost exactly 1.00 . The highest ratio obtained, however, was 1.32 (experiment $44 a$, table 60 ), from material the initial acidity of which was 0.81 per cubic centimeter pure juice and 2.05 per gram dry weight. On the other hand, the highest total acidity per gram dry substance, namely, 7.85 , had only a purejuice acidity of 1.57 , and gave a gas ratio of no more than 0.88 . Similarly, another group of experiments, 39 et seq., with the very high initial total acidity 
of 6.78 per gram dry weight and of 2.00 per cubic centimeter juice, gave at the beginning only a ratio of 0.83 , rising as the acidity diminished to 0.91 . Thus it may be seen that the question is by no means a simple one and that a proper understanding of the problem demands a closer analysis than is given by these general averages. Nevertheless, it is impressive that despite great variations, which, as will be shown later, are dependent upon the course of the acidity at the time the determination was carried on, the high acidities and high ratios go together. Later the conditioning circumstances of these various experiments will be considered.

It is the same with the low acidities and low ratios as with the higher ones. Great individual variation is found in the various experiments, but here, as in the other case, the age of the tissue and the course of the acidity are important influences. In the lowest ratio group, that below 0.40 , there were only two experiments which agreed well. One was with some mature-flaccid joints (experiment B', table 56) and the other was with young material (experiment 12, table 58). This latter gave the lowest gas ratio that was found, as follows: ratio 0.29 , acidity juice 0.38 per cubic centimeter, total acidity 0.72 per gram dry weight. The acidity was rising. The former with a considerably lower acidity gave a somewhat higher ratio. There were, it is true, a few experiments in which little or no carbon dioxide was produced and a considerable amount of oxygen was absorbed, but these departed so very widely from the rule that they may be regarded as somewhat anomalous. The lowest acidity, as far as the juice itself was concerned, was found in a young specimen (experiment $\mathrm{DD}^{3}$, table 55 ) and was but 0.16 , though the total acidity was not proportionally low. This specimen gave the low gas ratio of 0.53 , which is, however, considerably higher than either of the two mentioned above. Other cases of as low or even lower ratios were found, but with considerably greater acidity as indicated below.

TABLE 48.

\begin{tabular}{|c|c|c|c|c|c|}
\hline Age. & $\frac{\mathrm{CO}_{2}}{\mathrm{O}_{2}}$ & $\begin{array}{l}\text { Acidity, } \\
\text { juice } \\
\text { per c. c. }\end{array}$ & $\begin{array}{c}\text { Total } \\
\text { acidity } \\
\text { pergram, } \\
\text { dry } \\
\text { weight. }\end{array}$ & $\begin{array}{l}\text { No. of } \\
\text { expts. }\end{array}$ & Table. \\
\hline Young......... & 0.45 & 0.52 & 2.34 & $J^{\prime}$ & 55 \\
\hline Young....... & 0.50 & 0.38 & 0.73 & 12 & 58 \\
\hline Old, turgid. . & 0.50 & 0.40 & 1.53 & $F^{\prime}$ & 54 \\
\hline Old, turgid. . & 0.47 & 0.88 & 1.69 & 34 & 59 \\
\hline Old, flacoid. . & 0.51 & 0.55 & 0.68 & 4 & 57 \\
\hline
\end{tabular}

The variation is considerable, but not more than might be anticipated. In general, it is true that plants that have the lowest acidities give the lowest gas ratios, especially where they are mature and flaccid. From a closer study of the data, it becomes evident that the variation in the $\frac{\mathrm{CO}_{2}}{\mathrm{O}_{2}}$ ratio at any given acidity is very largely dependent upon whether the acidity happens to be rising or falling. Where the acid-content is high it is naturally usually falling, and rising where it is low. Consequently, the largest variation of gas ratio is to be expected in the middle ranges of acidity, since there would be less uniformity 
there in the course of the acidity. This is, indeed, the case, and in the subsequent analysis of the data from those experiments where the course of the acidity was known, the relation of the rise or fall of acid-content to the proportional evolution of carbon dioxide and absorption of oxygen will be discussed. The greatest range was found, as might be expected, in the young joints, which are far more active than the older joints, even when the latter are fully turgid.

\section{GAS RATIO AND RATE OF GAS INTERCHANGE.}

The actual rate of carbon-dioxide evolution and oxygen absorption shows a tendency to increase as the ratio rises; or rather, the more rapid gas interchange usually results in a higher ratio. This, indeed, is what might be anticipated, for, as table 49 shows, the acidities also rise with the ratios and the higher the acidity the greater the rapidity of gas interchange, since the breaking down of the acid is so intimately connected with these processes. There is in addition, of course, the influence of temperature, concerning which there has already been discussion. Nevertheless, in table 49, the averages now under consideration, where the arrangement of the data has been according to ratios, even the general averages of experiments at all temperatures show an increase of gas interchange with the ratio. In the first group an average of 17 experiments with a gas ratio of 0.46 gave a per gram-hour evolution of carbon dioxide of 0.089 c.e. fresh weight or 0.404 dry weight. Set against this, at the other end of the table, is the average of 14 experiments with a gas ratio of nearly 1.00 and an amount of evolved carbon dioxide about double that found in the previous case. It is more instructive, however, to take a single temperature group in this table and to follow it through the various ratios. Each temperature group shows a pretty constant increase in gas interchange, with the exception of that at $28^{\circ}$ to $30^{\circ} \mathrm{C}$., where there is irregularity, particularly with the higher ratios. This temperature group is compiled from the smallest number of experiments, and it happened, moreover, that the material giving the high gas ratios was exceptionally inactive.

The experiments made at between $31^{\circ}$ and $34^{\circ} \mathrm{C}$. were the most numerous, and that temperature is, indeed, nearly normal for these cacti. These show a consistent rise in activity with the rise in ratio. At the ratio of 0.82 there is nearly three times the amount of carbon dioxide given off as there is when the ratio is $\mathbf{0 . 4 5}$; while at the still higher ratio of 0.93 the increase approximates four times the amount of the original rate. All of the other temperature groups are sufficiently consistent to warrant the general statement that the greater the amount of gas interchange the more nearly the $\frac{\mathrm{CO}_{2}}{\mathrm{O}_{2}}$ quotient approaches unity. Indeed, it may surpass it. This of course means that while the evolution of carbon dioxide increases, the absorption of oxygen also increases, but not so rapidly.

It will be seen that along with the increasing ratios there is also increasing acidity, both of the juice and of the total quantity in the tissues. The general statement may be further supplemented by including this fact, and we may say that high acidities, high ratios, and high rate of gas interchange are all associated. When the acidity is high, there is, other things being equal, a marked inclination for it to fall if the slightest stimulus which favors the breaking down of the acids is present. Such conditions are realized in increase 
of illumination, prolonged darkness, or rise of temperature, and there may be others concerning which we have no data. The splitting of the acid demands a greater absorption of oxygen and results in still greater formation of carbon dioxide, so that the ratio must also rise until it approaches unity or even, in some cases, exceeds it. Where the ratio is increasing it must mean that some carbon dioxide is being formed without the intervention of atmospheric

TABLE 49.--General averages of 102 gas-interchange determinations made during the summers of 1912 and 1913, arranged according to ratios and grouped according to temperatures.

\begin{tabular}{|c|c|c|c|c|c|c|c|c|c|c|}
\hline \multirow{3}{*}{$\begin{array}{l}\text { No. of } \\
\text { expts } \\
\text { aver- } \\
\text { aged. }\end{array}$} & \multirow{3}{*}{$\begin{array}{c}\text { Groups of } \\
\mathrm{CO}_{2} / \mathrm{O}_{2} \\
\text { ratio. }\end{array}$} & \multirow{3}{*}{ Temp. } & \multirow{3}{*}{$\begin{array}{c}\text { Acidity } \\
\text { pure } \\
\text { juice, } \\
\mathrm{N} / 10 \\
\mathrm{KOH} \\
\text { per c.c. }\end{array}$} & \multirow{3}{*}{$\begin{array}{c}\text { Total } \\
\text { acidity } \\
\mathrm{N} / \mathbf{1 0} \\
\mathrm{KOH} \\
\text { per gm. } \\
\text { fresh } \\
\text { weight. }\end{array}$} & \multirow{3}{*}{$\begin{array}{c}\text { Total } \\
\text { acidity } \\
\mathrm{N} / 10 \\
\mathrm{KOH} \\
\text { per gm. } \\
\text { dry } \\
\text { weight. }\end{array}$} & \multirow{3}{*}{$\begin{array}{l}\text { Average } \\
\text { of } \\
\mathrm{CO}_{2} / \mathrm{O}_{2} \\
\text { ratios. }\end{array}$} & \multicolumn{4}{|c|}{ Gas interchange per gram-hour. } \\
\hline & & & & & & & \multicolumn{2}{|c|}{ Fresh weight. } & \multicolumn{2}{|c|}{ Dry weight. } \\
\hline & & & & & & & $\begin{array}{l}\mathrm{CO}_{2} \\
\text { evol. }\end{array}$ & $\begin{array}{c}\mathrm{O}_{2} \\
\text { abs. }\end{array}$ & $\begin{array}{l}\mathrm{CO}_{2} \\
\text { evol. }\end{array}$ & $\begin{array}{l}\mathrm{O}_{3} \\
\text { abs. }\end{array}$ \\
\hline 2 & \multirow{4}{*}{$\begin{array}{c}0.41 \\
\text { to } \\
0.50\end{array}$} & $\begin{array}{c}{ }^{\circ} \mathrm{C} \\
23 \text { to } 24\end{array}$ & $\begin{array}{l}\text { c.c. } \\
0.92\end{array}$ & $\begin{array}{l}\text { c.c. } \\
0.32\end{array}$ & $\begin{array}{l}\text { c.c. } \\
1.71\end{array}$ & 0.49 & $\begin{array}{c}\text { c.c. } \\
0.077\end{array}$ & $\begin{array}{c}c . c . \\
0.154\end{array}$ & $\begin{array}{c}c . e . \\
0.409\end{array}$ & $\begin{array}{c}\text { c.c. } \\
0.820\end{array}$ \\
\hline 6 & & 28 to 30 & 0.50 & 0.23 & 1.17 & 0.43 & .096 & .223 & .452 & 1.004 \\
\hline 4 & & 31 to 34 & 0.45 & 0.25 & 1. 12 & 0.45 & .075 & .167 & .330 & .739 \\
\hline 5 & & $(35$ to 37 & 0.34 & 0.22 & 0.91 & 0.48 & .093 & .195 & .392 & .817 \\
\hline 17 & \multirow{6}{*}{$\begin{array}{l}0.51 \\
\text { to } \\
0.60\end{array}$} & 23 to 37 & 0.47 & 0.23 & 0.97 & 0.46 & .089 & .194 & .404 & .856 \\
\hline 4 & & $(23$ to 24 & 1.06 & 0.60 & 1.80 & 0.53 & .075 & .144 & .390 & .720 \\
\hline 3 & & 28 to 30 & 0.31 & 0.22 & 0.98 & 0.55 & .098 & .175 & .450 & .828 \\
\hline 6 & & 31 to 34 & 0.53 & 0.24 & 0.96 & 0.56 & .118 & .209 & .471 & .832 \\
\hline 1 & & $(35$ to 37 & 0.50 & 0.22 & 0.65 & 0.59 & .099 & 169 & .295 & .502 \\
\hline 14 & & 23 to 37 & 0.64 & 0.34 & 1.50 & 0.56 & .100 & .180 & .433 & .774 \\
\hline 4 & \multirow{5}{*}{$\begin{array}{l}0.61 \\
\text { to } \\
0.70\end{array}$} & 23 to 24 & 1.00 & 0.55 & 2.35 & 0.68 & .096 & .141 & .509 & .739 \\
\hline 5 & & 28 to 30 & 0.54 & 0.32 & 2.34 & 0.64 & .113 & .179 & .504 & .792 \\
\hline 5 & & 31 to 34 & 0.50 & 0.29 & 1. 26 & 0.64 & .155 & .244 & .657 & 1.029 \\
\hline 2 & & 35 to 37 & 0.78 & 0.68 & 3.68 & 0.66 & .185 & .280 & 1.035 & 1.560 \\
\hline 16 & & 23 to 37 & 0.71 & 0.44 & 2.22 & 0.67 & .110 & .165 & .553 & .828 \\
\hline 2 & \multirow{3}{*}{$\begin{array}{l}0.71 \\
\text { to } \\
0.80\end{array}$} & 23 to 24 & 0.96 & 0.52 & 2.64 & 0.79 & .119 & .150 & .632 & .798 \\
\hline 8 & & $\left\{\begin{array}{l}28 \text { to } 30 \\
31 \text { to } 34\end{array}\right.$ & 0.84 & $\ddot{0}, \ddot{49}$ & 3.10 & & 198 & 264 & 1.208 & 1.606 \\
\hline 7 & & 35 to 37 & 0.89 & 0.50 & 2.35 & 0.75 & .177 & .236 & .850 & 1.113 \\
\hline 17 & \multirow{5}{*}{$\begin{array}{c}0.81 \\
\text { to } \\
0.90\end{array}$} & 23 to 37 & 0.88 & 0.50 & 2.75 & 0.75 & .180 & .239 & .986 & 1.315 \\
\hline 9 & & ( 23 to 24 & 1.54 & 0.98 & 4.20 & 0.84 & .131 & .156 & .664 & .792 \\
\hline 3 & & 28 to 30 & 1.24 & 0.79 & 4.83 & 0.86 & .110 & .130 & .687 & .820 \\
\hline 7 & & 31 to 34 & 1.28 & 0.87 & 4.78 & 0.82 & .206 & .240 & 1.147 & 1.346 \\
\hline 3 & & (35 to 37 & 1.26 & 0.83 & 8.98 & 0.90 & .237 & .263 & 1.528 & 1.712 \\
\hline 22 & \multirow{5}{*}{$0.91+$} & 23 to 37 & 1.45 & 0.94 & 4.68 & 0.86 & .176 & .205 & .992 & 1.156 \\
\hline 2 & & (23 to 24 & 2.32 & 1.38 & 5.75 & 1.00 & .139 & .139 & .720 & .725 \\
\hline 5 & & 28 to 30 & 1.32 & 0.82 & 5.27 & 0.94 & .173 & .184 & .711 & .754 \\
\hline 7 & & 31 to 34 & 1.38 & 0.87 & 2.72 & 0.93 & .277 & .299 & 1.500 & 1.620 \\
\hline $4^{1}$ & & 40 to 41 & 1.20 & 0.60 & 2.60 & 1.12 & .340 & .303 & 3.107 & 2.762 \\
\hline 14 & $\ldots . . .$. & 23 to 34 & 1.53 & 0.90 & 4.63 & 0.95 & .162 & .172 & .914 & .961 \\
\hline
\end{tabular}

${ }^{1}$ These four results not included in average. 
oxygen. The greatest contrast will naturally be found between those experiments where the temperature, acidity, and rate are low and those where all three are high. For example, at $28^{\circ}$ to $30^{\circ} \mathrm{C}$. with a total acidity of 1.17 per gram dry weight, the gas ratio is 0.43 with the evolution of carbon dioxide amounting to 0.452 e.c. per gram dry weight. At $40^{\circ}$ to $41^{\circ} \mathrm{C}$., with the total acidity of 2.66 and evolution of carbon dioxide of 2.572 per gram dry weight, the gas ratio is 1.20 . If the material used in the high-temperature experiments had chanced to have been of higher acidity, no doubt the contrast would have been even greater, That these differences exist is not astonishing, for the actual rate of gas interchange which accompanies the disruption processes connected with the breaking down of the acids must naturally be greater when the acidity is high than when it is low. The acids are undoubtedly the source of at least a considerable part of the carbon dioxide which is given off, so it is evident that when there is less actual acid present in the tissue there could not under any circumstances be so much carbon dioxide formed.

Attention is called to the fact that in discussing the general averages set forth in table 49 the four experiments at $40^{\circ}$ to $41^{\circ} \mathrm{C}$. have not been included, since only one series of relatively high acidity was carried on at this temperature. They are not, moreover, wholly comparable with the experiments carried on at a similar temperature which have already been discussed in connection with temperature effects. The experiments under consideration at present were made from fresh material at Tucson, while those cited earlier were carried out in New York from material collected in Tucson at another season of the year and kept for some time in the laboratory. They are, however, instructive in contrast with the Tucson experiments, in which both the ratio and the temperature were low.

\section{ACIDITY AND RATE OF GAS INTERCHANGE.}

Arranging the data from the Tucson experiments on still another basis, that of acidity, whether it be the acidity of the expressed juice or the total acidity per gram dry or per gram fresh weight, there is additional and corroborative evidence of some of the facts brought out in the preceding discussion. With the higher acidities there are, in general, a higher rate of gas interchange and corresponding higher gas ratios. This is always excepting the $40^{\circ}$ to $41^{\circ} \mathrm{C}$. series, which is not comparable with the others. At the dry weight, total acidity of 1.00 per gram, the ratio is about 0.50 ; at acidities from 1.01 to 3.00 per gram, the ratio averages 0.65 ; at from 3.01 to 5.00 per gram acidity, the ratio has risen to about 0.80 ; and finally, in the last group including acidities from 5.01 to 7.85 per gram (the highest found), the ratio is 0.88 . To summarize, the rate of evolution of carbon dioxide rises in the ratio of 4 to 9 from the lowest acidity to the highest, but (as before) the number of instances averaged was not always large enough to be free from the effect of special cases which depart from the usual conditions.

The series grouped between the temperatures of $31^{\circ}$ and $34^{\circ} \mathrm{C}$. is again the most consistent for the reason already mentioned, $i$. e., that a larger number of experiments are averaged. In the four acidity groups given in table 50, the gas ratios at this temperature rise as follows: $0.55,0.68,0.80,0.85$. The rate of carbon dioxide evolution rises as follows, $0.297,1.001,0.860,1.475$ c.c. per gram dry weight. The irregularity is due to the presence in the second 
acidity group of some experiments with material of very high acidity, so that the rate is higher than it should be. It is, of course, realized that in assembling the averages of these experiments, which are necessarily diverse because of the number of variables, there must be considerable irregularity in the results. It must be remembered that data from material in all conditions are included, both turgid and flaccid, mature joints and young ones. Notwithstanding this, the general tendencies stand out pretty clearly to support the conclusions already drawn regarding the association of high values in acidity, rate of gas interchange, and ratios of carbon dioxide evolved with oxygen absorbed. But this question has been discussed and requires no further treatment.

It is noticeable in table $\mathbf{5 0}$ that in the two lowest groups, which include material with dry-weight acidity up to 3.00 per gram, the upper limit of acidity

\section{TABLE 50.-Averages of 99 gas-interchange experiments made during the summers of 1918 and 191s, arranged according to acidity per gram dry weight.}

Averages of 99 gas-interchange experiments made during the summers of 1912 and 1913 are given in table 50, arranged according to acidity per gram dry weight expressed in terms of cubic centimeters of $\mathrm{N} / 10 \mathrm{KOH}$. The temperature groups correspond to the mean temperatures at which the majority of the experiments were conducted. In every case the acidities are expressed in terms of cubic centimeters of N/10 KOH per gram dry weight, and the amounts of $\mathrm{CO}_{2}$ evolved and $\mathrm{O}_{2}$ absorbed in cubic centimeters of gas per gram per hour.

\begin{tabular}{|c|c|c|c|c|c|c|c|c|c|}
\hline Acidity. & Temp. & $\begin{array}{c}\text { Acidity } \\
\text { per } \\
\text { gram, } \\
\text { dry } \\
\text { weight. }\end{array}$ & $\begin{array}{c}\text { A cidity } \\
\text { per } \\
\text { gram, } \\
\text { fresh } \\
\text { weight. }\end{array}$ & $\begin{array}{c}\text { Acidity } \\
\text { per c.c. } \\
\text { pure } \\
\text { juice. }\end{array}$ & $\begin{array}{c}\mathrm{CO}_{2} \\
\text { per } \\
\text { gram } \\
\text { per } \\
\text { hour, } \\
\text { dry } \\
\text { weight. }\end{array}$ & $\begin{array}{c}\mathrm{O}_{y} \text { ab- } \\
\text { sorbed } \\
\text { per } \\
\text { gram } \\
\text { per } \\
\text { hour, } \\
\text { dry } \\
\text { weight. }\end{array}$ & $\begin{array}{c}\mathrm{CO}_{2} \\
\text { evolved } \\
\text { per } \\
\text { gram } \\
\text { per } \\
\text { hour, } \\
\text { fresh } \\
\text { weight. }\end{array}$ & $\begin{array}{c}\mathrm{O}_{2} \mathrm{ab}- \\
\text { sorbed } \\
\text { per } \\
\text { gram } \\
\text { per } \\
\text { hour, } \\
\text { fresh } \\
\text { weight. }\end{array}$ & $\begin{array}{l}\mathrm{CO}_{2} / \mathrm{O}_{3} \\
\text { ratio. }\end{array}$ \\
\hline 1.00 and under. & 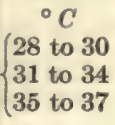 & $\begin{array}{l}\text { c.e. } \\
0.70 \\
0.75 \\
0.75\end{array}$ & $\begin{array}{l}\text { c.c. } \\
0.15 \\
0.23 \\
0.20\end{array}$ & $\begin{array}{l}\text { c.c. } \\
0.24 \\
0.43 \\
0.44\end{array}$ & $\begin{array}{c}c . c . \\
0.490 \\
0.297 \\
0.382\end{array}$ & $\begin{array}{c}c . c . \\
1.003 \\
0.542 \\
0.860\end{array}$ & $\begin{array}{l}c . c . \\
0.166 \\
0.091 \\
0.095\end{array}$ & $\begin{array}{l}c . c . \\
0.335 \\
0.165 \\
0.214\end{array}$ & $\begin{array}{l}0.49 \\
0.55 \\
0.44\end{array}$ \\
\hline 1.01 to 3.00 . & $\left\{\begin{array}{l}23 \text { to } 24 \\
28 \text { to } 30 \\
31 \text { to } 34 \\
35 \text { to } 37 \\
40 \text { to } 41\end{array}\right.$ & $\begin{array}{l}1.47 \\
1.64 \\
2.00 \\
1.90 \\
1.73\end{array}$ & $\begin{array}{l}0.31 \\
0.37 \\
0.35 \\
0.35 \\
0.38\end{array}$ & $\begin{array}{l}0.53 \\
0.75 \\
0.64 \\
0.82 \\
1.02\end{array}$ & $\begin{array}{l}0.392 \\
0.293 \\
1.001 \\
1.020 \\
2.740\end{array}$ & $\begin{array}{l}0.600 \\
0.551 \\
1.483 \\
1.443 \\
2.163\end{array}$ & $\begin{array}{l}0.074 \\
0.070 \\
0.184 \\
0.212 \\
0.442\end{array}$ & $\begin{array}{l}0.114 \\
0.132 \\
0.272 \\
0.300 \\
0.352\end{array}$ & $\begin{array}{l}0.65 \\
0.53 \\
0.68 \\
0.72 \\
1.12\end{array}$ \\
\hline 3.01 to $5.00 \ldots$ & $\left\{\begin{array}{l}23 \text { to } 24 \\
28 \text { to } 30 \\
31 \text { to } 34 \\
35 \text { to } 37 \\
40 \text { to } 41\end{array}\right.$ & $\begin{array}{l}3.65 \\
3.39 \\
4.01 \\
4.14 \\
3.58\end{array}$ & $\begin{array}{l}0.68 \\
0.69 \\
0.73 \\
0.79 \\
0.92\end{array}$ & $\begin{array}{l}1.34 \\
1.40 \\
1.12 \\
1.11 \\
1.36\end{array}$ & $\begin{array}{l}0.838 \\
0.672 \\
0.860 \\
1.210 \\
2.402\end{array}$ & $\begin{array}{l}1.002 \\
0.767 \\
1.152 \\
1.442 \\
2.013\end{array}$ & $\begin{array}{l}0.155 \\
0.120 \\
0.152 \\
0.197 \\
0.550\end{array}$ & $\begin{array}{l}0.186 \\
0.140 \\
0.191 \\
0.237 \\
0.262\end{array}$ & $\begin{array}{l}0.84 \\
0.85 \\
0.80 \\
0.82 \\
\cdots\end{array}$ \\
\hline 5.01 to $7.85 \ldots$ & $\left\{\begin{array}{l}23 \text { to } 24 \\
28 \text { to } 30 \\
31 \text { to } 34\end{array}\right.$ & $\begin{array}{l}5.96 \\
6.02 \\
6.15\end{array}$ & $\begin{array}{l}1.28 \\
0.88 \\
1.05\end{array}$ & $\begin{array}{l}2.11 \\
1.39 \\
1.52\end{array}$ & $\begin{array}{l}0.557 \\
0.812 \\
1.475\end{array}$ & $\begin{array}{l}0.642 \\
0.909 \\
1.737\end{array}$ & $\begin{array}{l}0.120 \\
0.128 \\
0.272\end{array}$ & $\begin{array}{l}0.136 \\
0.142 \\
0.322\end{array}$ & $\begin{array}{l}0.88 \\
0.90 \\
0.85\end{array}$ \\
\hline $\begin{array}{l}1.00 \text { and under. } \\
1.01 \text { to } 3.00 \ldots \\
3.01 \text { to } 5.00 \ldots\end{array}$ & $\left\{\begin{array}{l}\text { General } \\
\text { average } \\
27 \text { to } 37\end{array}\right\}$ & $\begin{array}{l}0.73 \\
1.85 \\
3.85\end{array}$ & $\begin{array}{l}0.19 \\
0.36 \\
0.74\end{array}$ & $\begin{array}{l}0.37 \\
0.74 \\
1.21\end{array}$ & $\begin{array}{l}0.390 \\
0.771 \\
0.914\end{array}$ & $\begin{array}{l}0.812 \\
1.159 \\
1.123\end{array}$ & $\begin{array}{l}0.121 \\
0.155 \\
0.156\end{array}$ & $\begin{array}{l}0.238 \\
0.233 \\
0.191\end{array}$ & $\begin{array}{l}0.51 \\
0.66 \\
0.82\end{array}$ \\
\hline $\begin{array}{l}1.00 \text { and under. } \\
1.01 \text { to } 3.00 \ldots \\
3.01 \text { to } 5.00 \ldots \\
5.01 \text { to } 7.85 \ldots\end{array}$ & $\begin{array}{l}\text { General } \\
\text { average } \\
27 \text { to } 34\end{array}$ & $\begin{array}{l}0.72 \\
1.82 \\
3.70 \\
6.08\end{array}$ & $\begin{array}{l}0.19 \\
0.36 \\
0.71 \\
0.96\end{array}$ & $\begin{array}{l}0.33 \\
0.69 \\
1.26 \\
1.40\end{array}$ & $\begin{array}{l}0.393 \\
0.647 \\
0.766 \\
1.124\end{array}$ & $\begin{array}{l}0.772 \\
1.017 \\
0.964 \\
1.323\end{array}$ & $\begin{array}{l}0.128 \\
0.127 \\
0.136 \\
0.200\end{array}$ & $\begin{array}{l}0.250 \\
0.202 \\
0.167 \\
0.232\end{array}$ & $\begin{array}{l}0.51 \\
0.66 \\
0.81 \\
0.86\end{array}$ \\
\hline
\end{tabular}


is reached at the higher temperatures, whereas in the highest acidity group, from 5.00 to 7.85 per gram, the reverse is the case, as the acidity is highest at the lowest temperature, $23^{\circ}$ to $24^{\circ} \mathrm{C}$. This is in accord with what has already been described in the previous chapter on acidity alone. When the acidity is low, high temperatures do not so greatly affect it; and if conditions are otherwise favorable for an increase, under such circumstances it will commonly rise. On the other hand, when the acidity is high it will fall if the temperature is raised, since the breaking down of the acid is considerably hastened thereby. This accounts for the condition just described. Left to itself without external stimulus, it may be supposed that the tissue establishes a certain equilibrium of acid concentration within itself, which is higher than that found in the lowest acidity group and lower than that of the highest group. In the former case, rising temperature may serve as a stimulus to acid formation, while in the latter case it acts in the opposite way. In this connection attention should again be called to the fact that too much stress should not be laid on the results of the series at $40^{\circ}$ to $41^{\circ} \mathrm{C}$. There were only a few experiments at this temperature and in these it chanced that the acidity of the juice was very high in proportion to the total acidity in the material used.

The relation between pure-juice acidity and dry-weight acidity must be dependent on the actual amount of juice present in the tissue. A high acidity of the expressed juice, with a low total acidity dry weight, must mean a relatively desiccated tissue; and the opposite must also be true. There is a considerable range of individual variation in this regard aside from the large differences which are to be noticed between what can readily be distinguished as turgid and flaccid joints. A study of loss or gain in acidity in relation to water loss or gain in the tissues would throw light on this question and would no doubt be of no little interest, but no such investigation was attempted.

In the matter of the relation of total acidity as calculated for dry and fresh weight, the proportion of one to the other must depend directly on the percentage of dry substance present, and naturally there will be greater disparity between the two with young and turgid joints than with old and flaccid ones.

\section{PURE-JUICE ACIDITY AND RATE OF GAS INTERCHANGE.}

It should be noted that the acidity of the undiluted juice as expressed from the tissues really means the concentration in terms of acid of that juice. Concentration should influence at least the speed of the reactions which are taking place and it is not without interest to examine the results considered on the basis of this pure-juice acidity, as shown in table 51. The irregularity of the gas interchange at different concentrations does not suggest that it plays a very important part, and a comparison with the previous table (50) of averages, where the basis of separation was dry-weight acidity, makes it seem that the actual quantity of acid present most greatly influences these phenomena. From the averages given here, however, it does appear that the evolution of carbon dioxide and absorption of oxygen are highest when the juice acidity is from 0.71 to 0.80 per cubic centimeter. To establish any certainty in this matter would require a very much larger number of experiments as well as the observation of certain precautions that were not taken inasmuch as this idea was an afterthought. 
TABLE 51.-Average of 99 gas-interchange experiments, arranged according to the acidity of the pure juice.

Average of 99 gas-interchange experiments, arranged according to the acidity of the pure juice, and grouped according to temperatures. The acidity is given in terms of cubic centimeters $\mathrm{N} / 10 \mathrm{KOH}$ per cubic centimeter pure juice. The $\mathrm{CO}_{2}$ and $\mathrm{O}_{2}$ are given according to cubic centimeters of gas per gram-hour, fresh weight.

\begin{tabular}{|c|c|c|c|c|c|}
\hline & \multicolumn{4}{|c|}{ Temperature. } & \multirow{2}{*}{ Average. } \\
\hline & 23 to 26 & 27 to 30 & 31 to 34 & 35 to 38 & \\
\hline \multicolumn{6}{|l|}{ Acidity below 0.50: } \\
\hline Acidity ........... & 0.45 & 0.20 & 0.40 & 0.40 & 0.30 \\
\hline Ratio $\mathrm{CO}_{2} / \mathrm{O}_{2} \ldots \ldots$ & 0.50 & 0.45 & 0.55 & 0.60 & 0.50 \\
\hline $\mathrm{CO}_{2}$ evolved.... & 0.055 & 0.085 & 0.135 & 0.091 & 0.100 \\
\hline $\mathrm{O}_{2}$ absorbed. & 0.116 & 0.180 & 0.255 & 0.150 & 0.195 \\
\hline \multicolumn{6}{|l|}{ Acidity 0.51 to 0.60 : } \\
\hline $\begin{array}{l}\text { Acidity } \ldots \ldots \ldots \\
\text { Ratio } \mathrm{CO}_{3} / \mathrm{O}_{\mathrm{z}} \ldots\end{array}$ & 0.55 & $\begin{array}{l}0.60 \\
0.65\end{array}$ & $\begin{array}{l}0.50 \\
0.70\end{array}$ & $\begin{array}{l}0.65 \\
0.75\end{array}$ & 0.50 \\
\hline $\begin{array}{l}\text { Ratio } \mathrm{CO}_{2} / \mathrm{O}_{2} \ldots . . \\
\mathrm{CO}_{2} \text { evolved..... }\end{array}$ & 0.50 & $\begin{array}{l}0.65 \\
0.070\end{array}$ & $\begin{array}{l}0.70 \\
0.115\end{array}$ & & 0.60 \\
\hline $\begin{array}{l}\mathrm{CO}_{2} \text { evolved...... } \\
\mathrm{O}_{2} \text { absorbed.... }\end{array}$ & $\begin{array}{l}0.100 \\
0.190\end{array}$ & $\begin{array}{l}0.070 \\
0.115\end{array}$ & 0.185 & 0.260 & 0.168 \\
\hline \multicolumn{6}{|l|}{ Acidity 0.61 to 0.70 : } \\
\hline Acidity.......... & 0.65 & 0.70 & 0.65 & $\cdots \cdots$ & 0.65 \\
\hline Ratio $\mathrm{CO}_{2} / \mathrm{O}_{2} \ldots$ & 0.95 & 1.00 & 0.70 & $\ldots$. & 0.70 \\
\hline $\mathrm{CO}_{2}$ evolved..... & 0.080 & 0.070 & 0.140 & ...... & 0.110 \\
\hline $\mathrm{O}_{2}$ absorbed..... & 0.085 & 0.070 & 0.210 & $\ldots \ldots$ & 0.146 \\
\hline \multicolumn{6}{|l|}{ Acidity 0.71 to 0.80 : } \\
\hline Ratio $\mathrm{CO}_{2} / \mathrm{O}_{2} \ldots \ldots$ & $\ldots$. & $\ldots$. & $\begin{array}{l}0.70 \\
0.75\end{array}$ & 0.80 & 0.80 \\
\hline $\mathrm{CO}_{2}$ evolved.... & $\ldots \ldots$ & .... & 0.230 & 0.273 & 0.250 \\
\hline $\mathrm{O}_{2}$ absorbed. . & $\ldots$. & $\ldots$. & 0.300 & 0.330 & 0.315 \\
\hline \multicolumn{6}{|l|}{ Acidity 0.81 to 0.90 : } \\
\hline Acidity.......... & 0.85 & 0.90 & 0.85 & 0.85 & 0.80 \\
\hline Ratio $\mathrm{CO}_{2} / \mathrm{O}_{2}$.. & 0.70 & 0.95 & 0.80 & 0.85 & 0.80 \\
\hline $\mathrm{CO}_{2}$ evolved. . & 0.080 & 0.075 & 0.200 & 0.160 & 0.180 \\
\hline $\mathrm{O}_{2}$ absorbed....... & 0.110 & 0.080 & 0.260 & 0.195 & 0.230 \\
\hline \multicolumn{6}{|l|}{ Acidity 0.91 to 1.00 : } \\
\hline $\begin{array}{l}\text { Acidity } \ldots \ldots \ldots \\
\text { Ratio } \mathrm{CO}_{2} / \mathrm{O}_{2}\end{array}$ & $\begin{array}{l}0.90 \\
0.90\end{array}$ & $\cdots \cdots$ & $\cdots \cdots$ & 0.85 & $\begin{array}{l}0.90 \\
0.90\end{array}$ \\
\hline $\mathrm{CO}_{2}$ evolved.... & 0.160 & ..... & $\ldots$. & 0.200 & 0.180 \\
\hline $\mathrm{O}_{2}$ absorbed.... & 0.175 & .... & ..... & 0.230 & 0.205 \\
\hline \multicolumn{6}{|l|}{ Acidity above 1.01: } \\
\hline Acidity ............ & 1.70 & 1.25 & 1.50 & 1.30 & 1.50 \\
\hline Ratio $\mathrm{CO}_{2} / \mathrm{O}_{2} \ldots$ & 0.70 & 0.70 & 0.90 & 0.90 & 0.85 \\
\hline $\mathrm{CO}_{2}$ evolved.... & 0.125 & 0.130 & 0.230 & 0.250 & 0.185 \\
\hline $\mathrm{O}_{2}$ absorbed. & 0.180 & 0.185 & 0.250 & 0.275 & 0.215 \\
\hline
\end{tabular}

\section{CERTAIN ANOMALOUS CASES.}

In four of the experiments carried out at Tucson during 1912 and 1913 there was an entire or practically entire cessation of carbon dioxide evolution. These must be regarded as anomalous, for they stand out sharply from all the others. The lowest gas ratio cited, that of 0.29 , where the amount of gas produced was greatly diminished, is hardly comparable with the condition of gas interchange found in these instances. The experiments in question are $\mathrm{K}^{\prime}$ and $\mathrm{DD}^{\prime}$ (table 64), where the amount of carbon dioxide found was minimal and $\mathrm{Q}^{\prime}, 1$, and 17 (table 64), where there was no evolution of carbon dioxide at 
all. In $\mathrm{K}^{\prime}$ the ratio sank to 0.02 and in $\mathrm{DD}^{\prime}$ to 0.05 , for, although the absorption of oxygen was about normal, the carbon dioxide given off was very slight. The acidity conditions in $\mathbf{K}^{\prime}$, which was with mature-turgid material both as to pure juice and total acidity, were not noteworthy, being neither very high nor very low. In the second case, the material of which was young, the acidity was high in the beginning, but fell off to a very great extent at the end. In this experiment, which ran for only $1 \frac{1}{2}$ hours, the acidity, both in juice and in total amount present, fell to less than an eighth of its initial figure. This was the greatest drop noted in so short a time. In the face of what all other experiments with falling acidity show, this is hard to understand, for it is to be expected that when the acid is diminished there would be a large evolution of carbon dioxide.

In the three other experiments, in which no carbon dioxide at all was found, the acidity varied. In $\mathrm{Q}^{\prime}$ with young material it was relatively high, and rose somewhat during the course of the experiment. In the other two instances, where flaccid material was employed (experiments 1 and 17), the acidity was low-in experiment 1 very low. As regards acidity, these results are conflicting and no conclusion can be drawn from them. However, as there was no adequate reason for excluding them, they were accepted, but have not been used in the general averages that have been discussed. It is possible that some unknown experimental condition affected the carbon-dioxide evolution. It does not seem probable that the results have important significance, and no further mention of them will be made.

\section{RELATION OF GAS RATIO TO COURSE OF ACIDITY.}

Of all the series of experiments, those carried on during the summer of 1913 are the most interesting. In these, as well as in a few conducted during the previous summer, the acidity of the material was determined at the beginning of the experiment (initial acidity) and also at the end (final acidity). Since determining the acid-content necessitates the destruction of the tissue, it was impossible to determine the initial acidity from the same specimen that was used for gas interchange. Consequently parallel material was employed which came from the same plant at the same time and from as nearly as possible the same region. The final acidity was always obtained from the specimens actually employed in the gas-interchange experiment. By this means, the important point as to whether the acidity was rising or falling could be determined with tolerable certainty. The acidity of different plants has been found to be very different, but the acidity of neighboring parts of the same plant, where the tissues are of the same age, is closely similar. Table 52 gives the averages for these experiments. It brings out conspicuously that with low acidities that are rising the gas ratio is usually low, while with high acidities that are falling the ratio approximates unity. This fact has been hinted in several places in this paper, but no detailed consideration of these important points has as yet been made.

In the first group there is but one experiment which gave a $\frac{\mathrm{CO}_{2}}{\mathrm{O}_{2}}$ quotient of 0.29 , with a total acidity that rose to nearly double the original amount during the course of the experiment (experiment 12a, table 58). The material used was a young joint in active growth; but, despite this, the acidity was low, the 
experiment having been begun at $4 \mathrm{p}$. m. It has already been cited as having given the lowest gas-interchange ratio that was obtained in any case. In this connection it is to be noted that the rise in acidity during the course of the experiment was relatively very great, all of which is in keeping with the statement just made regarding the relation of the course of the acidity and the proportion of carbon dioxide evolved to oxygen absorbed. However striking the result of this individual experiment may be, it would, of course, not have important significance did it not show correlation with the others in the series. All of the other ratio groups are averages of several experiments, as indicated in table 52, and consequently carry more weight, especially since they form a consistent series. This table of averages shows an acidity greater at the end than at the beginning, up to the ratio group 0.71 to 0.80 , where the total dry-weight acidity is 2.13 at the beginning and 2.23 at the end. Above that, in the two highest ratio groups, the acidity, which is also high, is falling.

TABLE 52.-General average of 51 gas-interchange determinations during summer of 1913, arranged according to $\mathrm{CO}_{2} / \mathrm{O}_{2}$ ratios and showing average acidity at beginning and at end of experiments.

\begin{tabular}{|c|c|c|c|c|c|c|c|c|}
\hline \multirow{2}{*}{$\begin{array}{l}\text { No. of } \\
\text { expts. }\end{array}$} & \multirow{2}{*}{ Ratio. } & \multirow{2}{*}{$\begin{array}{c}\text { Average } \\
\text { of } \\
\text { ratios. }\end{array}$} & \multicolumn{2}{|c|}{$\begin{array}{c}\text { Average of acid- } \\
\text { ity, pure juice, } \\
\text { per c.c. } \\
\text { (c.c. N / } 10 \mathrm{KOH} \text { ). }\end{array}$} & \multicolumn{2}{|c|}{$\begin{array}{l}\text { Average of total } \\
\text { acidity per gram, } \\
\text { fresh weight, } \\
\text { (c.c. } \mathrm{N} / 10 \mathrm{KOH}) .\end{array}$} & \multicolumn{2}{|c|}{$\begin{array}{l}\text { Average of total } \\
\text { acidity per gram, } \\
\text { dry weight, } \\
\text { (c.c. N/10 KOH). }\end{array}$} \\
\hline & & & $\begin{array}{l}\text { Begin- } \\
\text { ning. }\end{array}$ & End. & $\begin{array}{l}\text { Begin- } \\
\text { ning. }\end{array}$ & End. & $\begin{array}{l}\text { Begin- } \\
\text { ning. }\end{array}$ & End. \\
\hline 1 & Below $0.40 \ldots . .$. & 0.29 & 0.38 & 0.52 & 0.16 & 0.28 & 0.72 & 1.25 \\
\hline 9 & 0.41 to $0.50 \ldots$. & 0.45 & 0.65 & 0.68 & 0.26 & 0.27 & 1.19 & 1.22 \\
\hline 11 & 0.51 to $0.60 \ldots \ldots$ & 0.55 & 0.70 & 0.82 & 0.27 & 0.43 & 1.53 & 1.89 \\
\hline 8 & 0.61 to $0.70 \ldots \ldots$ & 0.67 & 0.80 & 0.89 & 0.43 & 0.48 & 1.79 & 2.00 \\
\hline 4 & 0.71 to $0.80 \ldots \ldots$ & 0.79 & 0.81 & 0.87 & 0.43 & 0.46 & 2.13 & 2.23 \\
\hline 10 & 0.81 to $0.90 \ldots \ldots$ & 0.84 & 1.52 & 1.44 & 0.87 & 0.83 & 4.26 & 4.06 \\
\hline 8 & $0.90+\ldots \ldots \ldots \ldots$ & 1.05 & 1.64 & 1.53 & 0.97 & 0.84 & 4.33 & 3.97 \\
\hline
\end{tabular}

If we take the gas ratio of 0.30 as the low point and 1.00 as the high, which correspond very closely to the figures in table 52 , the middle point for the ratio would be 0.65 . This will be found to correspond approximately to the average middle point of the dry-weight acidity, which may be reckoned in a similar way from the figures in the table. So estimated, the dry-weight total acidity would be about 2.00. In table 52 the average $\frac{\mathrm{CO}_{3}}{\mathrm{O}_{3}}$ ratio of 0.67 has the average dry-weight acidity of 1.79 to 2.00 , which is as close a correspondence to the predicted value as could be expected. The ratio, then, rises with the acidity, and when the latter is at a point where it begins to fall the highest ratios are realized.

The analysis of individual experiments further corroborates this generalization. Experiments 3 and 4 (table 57) are comparable, the material being from similar plants and being carried on simultaneously. In the former, where a fall in acidity is indicated, the ratio is higher than in the latter where the acidity is stationary. In experiments 7 and 8 in the same table, which are also comparable, the acidity of the first rose slightly, while that of the 
second showed a considerable fall. The gas ratio of the latter was noticeably higher. Similarly in series 33 (table 59) the ratio was higher in the first one of the set, where the acidity was falling, than it was in $33 b$ where an increase in the acid-content was found. In the middle experiment, 33a, where a slight rise in acidity is indicated, it is true that the ratio is nearly as high as in 33 , but an exact mathematical correspondence is hardly to be anticipated. Also in series 34 (table 59), the rising acidity in 34 itself gave a lower ratio than $34 a$, where the amount of acid diminished. The last one of this set, $34 b$, had an acidity which remained stationary, the ratio again low, though somewhat higher than in the first experiment. In all of these cases the acidity was relatively low and the rise or fall was not very great. It was difficult, at least under the conditions of experimentation, to obtain a very great rise in acidity during the time of the experiments, which was usually not over 2 hours. In general, acidity rises more slowly than it falls, certainly when the diminution of the acid occurs in tissue where the initial accumulation is considerable.

In experiments 12 and $12 a$ (table 58) we have a case, however, where the acidity was at a very low point, yet showed a marked increase. These two experiments are comparable, for the material came from different branches of the same plant, and they were carried on at the same time. The acidity was rising in both, but it reached a higher point in $12 a$ than in 12 , almost doubling itself in the 2 hours during which the experiment was in progress. The ratio of experiment $12 a$ was very much lower than of experiment 12 ; indeed, it was, as has already been pointed out, the lowest ratio obtained. In experiment 12 the rise in acidity amounted to 37 per cent and the ratio was 0.50 ; in $12 a$, where the rise was 87.5 per cent, the ratio was 0.29 . The initial acidity was practically the same in both cases.

Hence it is evident that during the process of the accumulation of acid in the tissue, much less carbon dioxide is given off in proportion to the amount of oxygen absorbed, or vice versa. This statement is further supported by an examination of those experiments in which the initial acidity was high and falling (tables 60 and 61). In those where the gas interchange is going on at the most rapid rate, which means that the evolution of carbon dioxide is at its maximum, the ratio is of necessity higher. The group of experiments numbered from 39 to $39 c$ (table 60 ) makes this especially clear. The first two in this series were carried on at the temperature of $24^{\circ} \mathrm{C}$., and, while the fall in acidity was considerable, it was much less than in the other two, where the temperature was from $31^{\circ}$ to $32^{\circ} \mathrm{C}$. The ratio in the first case was 0.83 and in the latter was 0.90 . In every instance where the gas-interchange rate is high, which means also a high acidity that is ready to fall under even a slight stimulus, the ratio is also high. In other words, while more oxygen is absorbed with falling acidity under these conditions, the absorption does not keep pace with the increased evolution of carbon dioxide, so that the ratio naturally approaches more nearly to unity, or even at times exceeds it.

If general averages are compared, the following results are obtained: In 27 experiments, all of which showed acidity that was diminishing, the average ratio is 0.90 , with a total dry-weight acidity at the beginning of 4.50 per gram and of 3.16 per gram at the end. On the other hand, 21 experiments with material of low initial acidity that was on the increase gave an average ratio of 0.59 and an initial acidity of 1.44 per gram rising to 1.85 . Whether looked 
at individually or in the mass, it would appear, then, that there can be no question as to the relation of the course of acidity and the $\frac{\mathrm{CO}_{2}}{\mathrm{O}_{2}}$ ratio. Of course individual experiments occasionally depart from the general rule; for internal causes, concerning which we can have no information, may, no doubt, influence either the exhalation of carbon dioxide or the absorption of oxygen or both, and so affect the ratio in its relation to the acidity. However, the results agree in the main and show unequivocally that the above generalization is sound.

The very high ratio and exceedingly rapid gas interchange shown in $43 a$ and $44 a$ (table 60) have no great significance. In both cases, despite the relatively short period of the experiment, a very large amount of carbon dioxide accumulated in the flask, amounting to more than 12 per cent. As has been shown, the carbon dioxide-oxygen relation is disturbed when the former gas collects so largely. The experiments are included simply to show the effect of a longcontinued application of a relatively high temperature.

\section{EVOLUTION OF CARBON DIOXIDE IN DIFFUSE AND DIRECT SUNLIGHT.}

Because of the highly interesting results obtained by the Pettenkofer method to determine the formation of carbon dioxide in diffuse light and in direct sunlight, a considerable number of experiments were made under these conditions to ascertain the complete gas-interchange relations.

In the table giving the results of the experiments with diffuse light (table 62) it will be seen that the amount of carbon dioxide given off is not very different from that evolved in the dark. There is a tendency for the gas ratio, as it shows in the analysis of the atmosphere surrounding the plant, to rise somewhat. This is probably due to the use of oxygen formed in the tissues by the photosynthetic processes, for the higher ratio appears to be due rather to a lesser absorption of external oxygen than to an increase in the formation of carbon dioxide. In the two experiments $45 a$ and $46 a$ (table 62) there was almost no oxygen absorbed, in consequence of which the ratio rose in one case to 7.00 and in the other to 6.33 .

It would be a point of the highest interest to determine whether this phenomenon can be observed at all seasons of the year, or is, perhaps, only characteristic of the period of the summer rains, when the temperature is high and the fully turgid plants are rich in acid. It would also be important to ascertain the effect of lower temperatures and whether under such conditions the photosynthetic activity was less influenced than the processes which result in the liberation of carbon dioxide. It is not at all impossible that under low temperatures the amount of this gas evolved would be so reduced that it would all be consumed by the active chlorophyll-bearing tissue. The low temperature series ( 48 to 52 , inclusive, table 62 ) was earried on with material that was really in a flaccid condition, although it appeared nearly turgid to the eye. The percentage of dry weight was in the neighborhood of 30. Also, they were not carried on at Tucson, but at Carmel, California, from material which had been shipped from Arizona some weeks previously. The light conditions were not comparable with those in Tucson, but of much less intensity, although described as the "bright diffuse light" of that seacoast region. Consequently, these experiments are not directly parallel with the others 
shown in table 62. However, the results of the two controls carried on in the dark show that the same general conditions prevail.

Evolution of carbon dioxide by plants in diffuse light has been noted before by Garreau ${ }^{\alpha}$ and in cacti especially by Aubert, but in none of the cases cited by these writers was there so considerable an amount of carbon dioxide formed. It seems hardly possible that so large an evolution of this gas takes place at all times of the year, for the actual loss of substance is not inconsiderable. It must be remembered, however, that under natural conditions the cacti are not exposed to a subdued light and the relatively feeble photosynthetic action of the limited amount of chlorophyll-bearing tissue is not enough to outweigh the action of light in breaking down the organic acids present.

What is more surprising than the evolution of carbon dioxide in diffuse light is the considerable amount that is given off when the plants are exposed to the direct rays of the sun (table 63). As has already been described, the manner of exposing the cactus joints in a closed vessel to the sun's rays was to immerse the container in ice-cooled water. It is realized that under such conditions the full effect of the sunlight might not be obtained, but nevertheless, there is a marked effect. The results corroborate those by the Pettenkofer method, which have been given in detail. Unlike the action in diffuse light there is no oxygen absorbed from the external air in normal active tissue either young or old; instead, an increase in the oxygen content was observed. It may reasonably be supposed that the photosynthetic processes afforded the oxygen necessary for the breaking down of the acids, and that which escaped was the surplus not used in these disintegration operations. The actual amount of oxygen given off varied considerably; in one case it was minimal, but in three other instances it averaged 0.45 c.c. per gram hour. The evolution of carbon dioxide, while much less than that found in diffuse light, was by no means negligible, but here also there is a great variation in amounts. In one case it was 0.072 per gram-hour, dry weight, in another as high as 0.432 . It is noticeable that in experiments TT and UU (table 63), where there is more carbon dioxide, there is less oxygen, and vice versa. In the one instance in which young material was used, there was a very large amount of carbon dioxide formed, nearly 0.84 c.c. per gram-hour, dry weight.

As would be anticipated, the acidity was falling rapidly in all these sunlight experiments, and it is probable that the photochemical action of the sun's rays caused such a rapid splitting of the organic acids that the amount of carbon dioxide produced was more than could be taken care of by the chlorophyll tissue.

In the two experiments tried with flaccid material, absorption of oxygen was indicated even under exposure to sunlight. The gas ratio is rather more than unity, and of about the same magnitude as that found in the dark (see table 56 for comparison). It seems questionable, then, if in the flaccid plants there is more than a much reduced photosynthetic activity or perhaps none at all. A mere external examination of an old, thoroughly flaccid joint suggests at once that its photosynthetic activity is probably minimal, for the color is commonly far from the normal green, and the chlorophyll appears not to be simply masked, but really of a yellowish color. It is true that for the amount of carbon dioxide produced, there is less external oxygen absorbed in these plants

${ }^{a}$ Garreau. Annal. de sci. nat. Botanique, series 3, vol. Xv, p. 6, 1851. 
exposed to the sunlight, so that it is probable that some of the latter gas is afforded the plant from that which is liberated by the feeble action of the chlorophyll-bearing tissue.

Appended to table 63 are the results of four experiments (RR, WW, SS, ZZ) carried on in sunlight, which are exceedingly perplexing. Since there was no known reason for excluding them, they have perforce been incorporated with the rest. Two of them were with young material and two with mature-turgid joints. In all, there was a very small evolution of carbon dioxide and a very large absorption of oxygen. In fact, the oxygen absorption exceeds that found in any other series of experiments. What the cause may have been for this extraordinary behavior there is no clue. It is possible that there was some hidden experimental error, but the records of the experiments give no information which will afford an explanation.

The question of the reaction of these cacti in the sunlight brings up many interesting problems. It would seem that at the time of year when there is large storage of acid and when the temperatures are relatively high there must be an actual loss of weight as a result of the action of the light upon the stored acids. It is not to be denied that during such periods-in the summer rainy season-Opuntia versicolor makes its growth, and makes it seemingly at the expense of its stored food supply. The photosynthetic activities do not keep pace with the growth metabolism. It is suggested by these results that the actual accumulation of energy for growth must take place during the cooler periods of the year, but at a time when the tissues are turgid and consequently active. This would be during the winter rains, and the relatively cooler spring season which follows them. It is at that time, indeed, that many of the other Opuntias make their growth and when the majority of them produce their flowers. The subject is one of no little interest and demands investigation in an extensive manner. It is to be regretted that no determinations of gas interchange in sunlight were made at lower temperatures, which might have afforded the answer to this question. It is, of course, quite impossible that this evolution of carbon dioxide is a constant phenomenon under all conditions of illumination unless we were to imagine the preposterous possibility that these cacti are nourished by the mycorrhizas which exist on their root systems. There can not be any reason for doubting the experiments, and the fact that another experimental method, that of the Pettenkofer apparatus, yielded similar results, gives additional consideration for accepting them. Care was taken to exclude the possibility of external non-chlorophyll-bearing organisms influencing the results, and the material used was inspected with especial care to make sure that no insect grubs were harbored in the tissues, so that possible contamination of the results by carbon dioxide from these sources may be neglected.

\section{EVOLUTION OF CARBON DIOXIDE IN THE ABSENCE OF OXYGEN.}

In the experiments tried with an atmosphere of practically pure hydrogen, there is naturally no question of a $\frac{\mathrm{CO}_{2}}{\mathrm{O}_{3}}$ ratio (table 65). The small percentage of oxygen which was present at the beginning of the experiment had disappeared at the time the gas sample was collected. The main point of interest here is the relatively high rate of the earbon-dioxide production, despite the absence of oxygen. 
The mature joints showed an evolution of carbon dioxide of 0.11 c.c. per gram-hour fresh weight in the absence of oxygen and of 0.16 c.c. in normal air. while with the young joints the amounts stand, respectively, 0.25 e.c. and 0.35 c.c. In comparing these figures with those of the Pettenkofer determinations, it will be seen that they are in accord with the latter. With the Pettenkofer experiments it will be remembered that at $21^{\circ} \mathrm{C}$. about half as much carbon dioxide was evolved in the absence of oxygen as was the case in normal air, while at $30^{\circ} \mathrm{C}$. the amounts were nearly equal. In those now under consideration the difference in the behavior of the plants in an atmosphere of hydrogen and in normal air is greater than that found at $30^{\circ} \mathrm{C}$. and less than that at $21^{\circ} \mathrm{C}$.; but it will be noticed that the temperature is also intermediate, being $27.5^{\circ} \mathrm{C}$. The actual quantity of carbon dioxide evolved is less in these experiments, which were carried on at Tueson in 1912, than in the Pettenkofer experiments which were made in New York. This difference has already been discussed in connection with other determinations and nothing further need be said. Reducing the volume of the gas to weight in milligrams, we have the following figures: mature material in hydrogen, $0.16 \mathrm{mg}$. per gram-hour fresh weight, in air $0.23 \mathrm{mg}$.; young material in hydrogen, $0.36 \mathrm{mg}$. per gram-hour, in air $0.50 \mathrm{mg}$. These quantities are closely similar to those found in two of the Pettenkofer series (tables 32 and 33), but considerably less than the amounts shown in table 34 .

For the sake of convenience, this evolution of earbon dioxide may be referred to as intramolecular respiration without making a definite statement as to whether or not it is entirely comparable with intramolecular respiration as ordinarily understood. As the hydrogen used in the containers was of a purity of 99.5 per cent, only a very minimal quantity of the evolved gas can be ascribed to the absorption of external oxygen. If the impurity was air, which may be fairly assumed, then the actual percentage of oxygen present was no more than 0.1 per cent, an amount which, as has been said, must speedily be absorbed. It has been shown that the acidity as determined by the method employed did not diminish at the rate at which it does in the presence of oxygen, and that, indeed, is what is to be expected. Consequently, the carbon dioxide which is formed does not seem to have come from the breaking up of the acid to the same extent as in the normal cases. It is possible that the preliminary steps in the degeneration of the malic acid may take place, thereby releasing an amount of carbon dioxide, but at the same time maintaining an acidity that would be evident by the titration method. Whether this is the case could only be determined by a more precise examination of the acid content of the tissue than was attempted. The whole question of the so-ealled intramolecular respiration in these forms is well worthy of closer study.

\section{INCREASED OXYGEN SUPPLY AND GAS INTERCHANGE.}

An increased supply of oxygen tends to raise rather than to lower the gas ratio, as is shown by the experiments set forth in table 66. From the results of the experiments on carbon dioxide evolution with the Pettenkofer apparatus it has been seen that the rate of the production of this gas is greatly increased, and this is borne out by the experiments now under discussion. The intake of oxygen is also increased, but it does not keep pace with the larger output of carbon dioxide. Consequently, the gas ratio must rise. 
In all of the three experiments, with a not especially high acidity, there is a high ratio, which averages close to unity; while the corresponding control experiments in ordinary air show a ratio that is nearer 0.75 . The increase of carbon dioxide is shown by these experiments to be from twice to three times that which it is in air. In the acidity experiments already described, it has been shown that there is a diminution of acidity with increased oxygen, so that it seems probable that the effect of the additional supply is largely to hasten the disintegration of the acids. High gas ratios can only mean an increase in the breaking-down processes which liberate carbon dioxide, unless they are caused by a diminution of the amount of oxygen absorbed, which is not the case in this instance. The number of experiments with increased oxygen-supply was limited and none was tried with material either of very high or of low acidity. In the former case we may surmise that the only effect would be that the amount of carbon dioxide produced would be still greater and the ratio even higher. In the latter case the effect of the additional oxygen would be to prevent the accumulation of acid, and as a consequence the ratio also would be higher than under normal conditions.

\section{GAS INTERCHANGE OVER LONG PERIODS.}

During the first summer when the gas-interchange determinations were made, a considerable number of experiments were carried out in which the carbon dioxide was allowed to accumulate in the receiver for considerable periods. As the amount of material used in these determinations was the same as that employed where the time period was much shorter, the amount of this gas which gathered was considerable, amounting usually to 12 and in one case to as much as 18 per cent. These have not been included in the general consideration of the results, since it is known that the presence of so much carbon dioxide in the surrounding air affects the ratio of gas interchange. A few of these results are given in table 67 . The chief effect seems to be the proportional diminution in the amount of oxygen absorbed, in consequence of which the ratio is high, considering the acidity of the specimen. The amount of carbon dioxide is also less than under more normal conditions, which perhaps may be ascribed to the effect of the carbon dioxide which accumulated, rather than to the lessened oxygen supply. The long-period experiments tried in 1913, where the amount of material was adjusted to the duration of the experiment and no great accumulation of carbon dioxide took place, gave normal results (experiments $35,36,29,25 b, 26 b, 27 b$, table 59 ). The occasion for mentioning the experiments described above is chiefly to call attention to the effect of increased carbon dioxide content of the surrounding air. They have otherwise no particular significance. 


\section{EXPERIMENTAL DATA OF GAS-INTERCHANGE DETERMINATIONS.}

In all of these experiments the lettered series were made in 1912, those with numbers in 1913. In any one series the same letter or figure indicates that the same material was used, the individual members of the series being shown by an index figure or letter.

\section{TABLE 53.-Temperalure and gas-interchange.}

The material used was all mature and fairly turgid joints of Opuntia versicolor. It had been sent from Tucson, Arizona, and kept for some weeks in the laboratory in New York at a temperature of from $20^{\circ}$ to $22^{\circ} \mathrm{C}$. and under conditions which prevented any considerable drying. The material was a mixed lot, and various determinations of the acidity showed the value of 1 c.c. pure juice to be from 0.9 to 1.10 c.c. $\mathrm{N} / 10$ alkali. Under the conditions at which it was kept the acidity remained fairly constant. During actual experimentation it was not kept long enough at the extremes of temperature to greatly affect the acidity, though there was the usual tendency for the amount of acid to increase at the lower temperature and to decrease at the higher. The material was respectively cooled or warmed for from 2 to 3 hours before the corresponding determination was made. At other times it was at ordinary room temperature of $20^{\circ}$ to $22^{\circ} \mathrm{C}$. Determinations were made in New York during April 1912.

\begin{tabular}{|c|c|c|c|c|c|c|}
\hline $\begin{array}{l}\text { Designa- } \\
\text { tion of ex- } \\
\text { periment. }\end{array}$ & Date and time. & $\begin{array}{l}\text { Dura- } \\
\text { tion. }\end{array}$ & Temp. & $\begin{array}{c}\text { Fresh } \\
\text { weight. }\end{array}$ & $\begin{array}{l}\text { Total } \\
\mathrm{CO}_{2} .\end{array}$ & $\begin{array}{c}\text { Total } \\
\mathrm{O}_{2} .\end{array}$ \\
\hline $\begin{array}{l}\text { Temp. } \mathbf{A}^{1} \\
\text { Temp. } \mathbf{A}^{2} \\
\text { Temp. } \mathbf{A}^{3}\end{array}$ & $\begin{array}{l}\text { Apr. } 10,9 \text { a. m. to } 12 \text { noon.......... } \\
\text { Apr. } 11,8^{\mathrm{h}} 30^{\mathrm{m}} \text { a. m. to } 12 \text { noon...... } \\
\text { Apr. 11, } 4 \text { p. m. to } 5 \text { p. } \mathrm{m} \ldots \ldots \ldots \ldots\end{array}$ & $\begin{array}{l}h r 8 \\
3 \\
3 \frac{1}{2} \\
1\end{array}$ & $\begin{array}{l}{ }^{\circ} C \\
15 \\
25 \\
40\end{array}$ & $\begin{array}{l}g m . \\
34.5 \\
34.5 \\
34.5\end{array}$ & $\begin{array}{l}\text { c.c. } \\
8.13\end{array}$ & $\begin{array}{c}\text { c.c. } \\
18.47 \\
26.68 \\
12.05\end{array}$ \\
\hline $\begin{array}{l}\text { Temp. } B^{1} \\
\text { Temp. } B^{2} \\
\text { Temp. } B^{3}\end{array}$ & $\begin{array}{l}\text { Apr. } 10,9^{\mathrm{h}} 15^{\mathrm{m}} \text { a. m. to } 12^{\mathrm{h}} 15^{\mathrm{m}} \text { p. m... } \\
\text { Apr. } 11,8^{\mathrm{h}} 45^{\mathrm{m}} \text { a. m. to } 12^{\mathrm{h}} 15^{\mathrm{m}} \text { p. m... } \\
\text { Apr. } 11,4^{\mathrm{h}} 15^{\mathrm{m}} \text { p. m. to } 5^{\mathrm{h}} 30^{\mathrm{m}} \text { p. m... }\end{array}$ & $\begin{array}{l}3 \\
3 \frac{1}{2} \\
1 \frac{1}{4}\end{array}$ & $\begin{array}{l}15 \\
25 \\
40\end{array}$ & $\begin{array}{l}35.0 \\
35.0 \\
35.0\end{array}$ & $\begin{array}{r}8.84 \\
19.47\end{array}$ & $\begin{array}{l}20.00 \\
23.95 \\
19.17\end{array}$ \\
\hline $\begin{array}{l}\text { Temp. } C^{1} \\
\text { Temp. } C^{2} \\
\text { Temp. } C^{3}\end{array}$ & $\begin{array}{l}\text { Apr. } 19,11 \text { a. } \mathrm{m} \text {. to } 2 \text { p. m......... } \\
\text { Apr. } 20,9 \text { a. m. to } 12 \text { noon } \ldots \ldots \ldots \ldots \\
\text { Apr. } 20,3^{\mathrm{h}} 45^{\mathrm{m}} \text { p. m. to } 5 \text { p. } \mathrm{m} \ldots \ldots \ldots\end{array}$ & $\begin{array}{l}3 \\
3 \\
1 \frac{1}{4}\end{array}$ & $\begin{array}{l}15 \\
25 \\
40\end{array}$ & $\begin{array}{l}28.0 \\
28.0 \\
28.0\end{array}$ & $\begin{array}{r}6.27 \\
11.47 \\
15.93\end{array}$ & $\begin{array}{l}12.05 \\
18.70 \\
22.65\end{array}$ \\
\hline $\begin{array}{l}\text { Temp. } D^{1} \\
\text { Temp. } D^{2} \\
\text { Temp. } D^{3}\end{array}$ & $\begin{array}{l}\text { Apr. } 19,11^{\mathrm{h}} 10^{\mathrm{m}} \text { a. m. to } 2^{\mathrm{h}} 10^{\mathrm{m}} \text { p. m.... } \\
\text { Apr. 20, } 9^{\mathrm{h}} 05^{\mathrm{m}} \text { a. m. to } 10^{\mathrm{h}} 05^{\mathrm{m}} \text { a. m } \ldots . . \\
\text { Apr. 20, } 3^{\mathrm{h}} 30^{\mathrm{m}} \text { p. m. to } 4^{\mathrm{h}} 45^{\mathrm{m}} \text { p. m... }\end{array}$ & $\begin{array}{l}3 \\
3 \frac{1}{2} \\
1 \frac{1}{4}\end{array}$ & $\begin{array}{l}15 \\
25 \\
40\end{array}$ & $\begin{array}{l}33.5 \\
33.5 \\
33.5\end{array}$ & $\begin{array}{r}6.65 \\
15.72 \\
19.00\end{array}$ & $\begin{array}{l}15.15 \\
25.90 \\
27.90\end{array}$ \\
\hline $\begin{array}{l}\text { Designa- } \\
\text { tion of ex- } \\
\text { periment. }\end{array}$ & Date and time. & \multicolumn{2}{|c|}{$\begin{array}{l}\mathrm{CO}_{2} \\
\text { evolved } \\
\text { per gram } \\
\text { per hour. }\end{array}$} & \multicolumn{2}{|c|}{$\begin{array}{l}\mathrm{O}_{2} \\
\text { absorbed } \\
\text { per gram } \\
\text { per hour. }\end{array}$} & $\begin{array}{l}\text { Ratio, } \\
\mathrm{CO}_{2} / \mathrm{O}_{2} \text {. }\end{array}$ \\
\hline $\begin{array}{l}\text { Temp. } \mathbf{A}^{1} \\
\text { Temp. } A^{2} \\
\text { Temp. } A^{3}\end{array}$ & $\begin{array}{l}\text { Apr. } 10,9 \text { a. } \mathrm{m} . \text { to } 12 \text { noon } \ldots \ldots \ldots \ldots \\
\text { Apr. } 11,8^{\mathrm{h}} 30^{\mathrm{m}} \text { a. } \mathrm{m} \text {. to } 12 \text { noon. } \ldots \\
\text { Apr. } 11,4 \text { p. m. to } 5 \text { p. } \mathrm{m} \ldots \ldots\end{array}$ & & $\begin{array}{l}0 . c . \\
072 \\
127 \\
325\end{array}$ & $\begin{array}{l}\text { c.c. } \\
0.17 \\
0.22 \\
0.34\end{array}$ & & $\begin{array}{l}0.44 \\
0.57 \\
0.93\end{array}$ \\
\hline $\begin{array}{l}\text { Temp. } \mathbf{B}^{1} \\
\text { Temp. } \mathbf{B}^{2} \\
\text { Temp. } \mathbf{B}^{3}\end{array}$ & $\begin{array}{l}\text { Apr. } 10,9^{\mathrm{h}} 15^{\mathrm{m}} \text { a. m. to } 12^{\mathrm{h}} 15^{\mathrm{m}} \text { p. } \mathrm{m} . \ldots \\
\text { Apr. } 11,8^{\mathrm{h}} 45^{\mathrm{m}} \text { a. m. to } 12^{\mathrm{h}} 15^{\mathrm{m}} \text { p. m... } \\
\text { Apr. } 11,4^{\mathrm{h}} 15^{\mathrm{m}} \text { p. m. to } 5^{\mathrm{h}} 30^{\mathrm{m}} \text { p. m.... }\end{array}$ & & $\begin{array}{l}.084 \\
.159 \\
.445\end{array}$ & $\begin{array}{l}0.19 \\
0.19 \\
0.43\end{array}$ & & $\begin{array}{r}0.44 \\
-0.81 \\
1.02\end{array}$ \\
\hline $\begin{array}{l}\text { Temp. } C^{3} \\
\text { Temp. } C^{2} \\
\text { Temp. } C^{3}\end{array}$ & $\begin{array}{l}\text { Apr. } 19,11 \text { a. } \mathrm{m} . \text { to } 2 \text { p. } \mathrm{m} . \ldots \ldots \ldots \ldots \\
\text { Apr. } 20,9 \text { a. } \mathrm{m} \text {. to } 12 \text { noon } \ldots \ldots \ldots \ldots \\
\text { Apr. } 20,3^{\mathrm{h}} 45^{\mathrm{m}} \text { p. } \mathrm{m} \text {. to } 5 \text { p. } \mathrm{m} \ldots \ldots \ldots\end{array}$ & & $\begin{array}{l}075 \\
.136 \\
455\end{array}$ & $\begin{array}{l}0.14: \\
0.22 \\
0.647\end{array}$ & & $\begin{array}{l}0.52 \\
0.60 \\
0.70\end{array}$ \\
\hline $\begin{array}{l}\text { Temp. } D^{1} \\
\text { Temp. } D^{2} \\
\text { Temp. } D^{3}\end{array}$ & $\begin{array}{l}\text { Apr. } 19,11^{\mathrm{h}} 10^{\mathrm{m}} \text { a. } \mathrm{m} \text {. to } 2^{\mathrm{h}} 10^{\mathrm{m}} \text { p. } \mathrm{m} . \ldots \\
\text { Apr. } 20,9^{\mathrm{h}} 05^{\mathrm{m}} \text { a. } \mathrm{m} \text {. to } 10^{\mathrm{h}} 05^{\mathrm{m}} \text { a. } \mathrm{m} \ldots \ldots \\
\text { Apr. } 20,3^{\mathrm{h}} 30^{\mathrm{m}} \text { p. } \mathrm{m} \text {. to } 4^{\mathrm{h}} 45^{\mathrm{m}} \text { p. } \mathrm{m} . \ldots\end{array}$ & & $\begin{array}{l}066 \\
134 \\
454\end{array}$ & $\begin{array}{l}0.151 \\
0.22 \\
0.65\end{array}$ & & $\begin{array}{l}0.44 \\
0.60 \\
0.69\end{array}$ \\
\hline
\end{tabular}




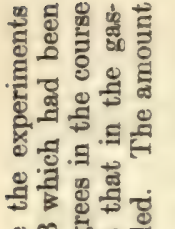
요유

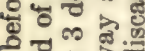

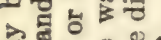
赵

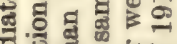

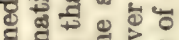
胃.

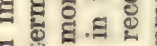

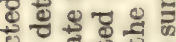

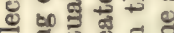
의

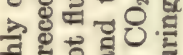

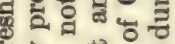
.

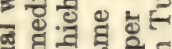

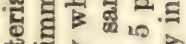

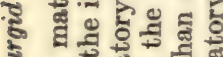

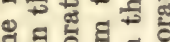

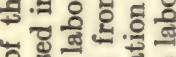

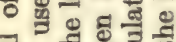
₹. 낭 궁 I0. เ 可品嵒 ए। 단 要 है 政 क 要

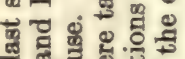
응 웅 현료 응 吼

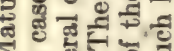
o 뎨 든

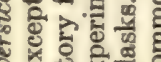
항ㅎㅀ 중

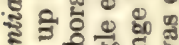

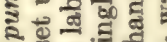
ฌ 政

\begin{tabular}{|c|c|c|c|c|c|c|c|c|c|}
\hline \multirow{3}{*}{ 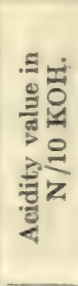 } & \multicolumn{2}{|c|}{ 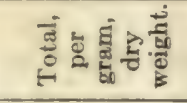 } & 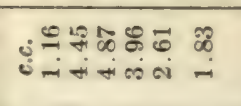 & 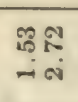 & †े & 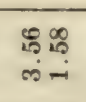 & สุฐ & $\begin{array}{l}\text { 용 } \\
\text { +i }\end{array}$ & 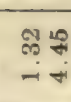 \\
\hline & \multicolumn{2}{|c|}{ 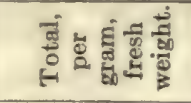 } & 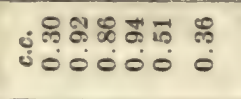 & $\begin{array}{l}\text { 藏 } \\
00\end{array}$ & $\begin{array}{l}5 \\
00 \\
00\end{array}$ & $\begin{array}{l}\text { R. } \\
0.0 \\
00\end{array}$ & $\begin{array}{l}\infty \pi+1 \\
00 \\
00\end{array}$ & $\begin{array}{l}0 \\
0 \\
0 \\
0 \\
0\end{array}$ & 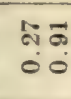 \\
\hline & \multicolumn{2}{|c|}{ 造苛苛 } & نी & P. & $\begin{array}{l}\vec{\infty} \infty \\
-i 0\end{array}$ & $\begin{array}{l}\text { क्ष } 80 \\
-0 \\
-0\end{array}$ & 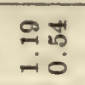 & 星 & 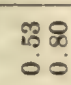 \\
\hline \multicolumn{3}{|c|}{ 'орџม ${ }^{8} \mathrm{O} /{ }^{2} \mathrm{O}$} & $\begin{array}{l}\text { Noד } 0008 \\
0000000 \\
00000\end{array}$ & 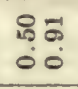 & $\begin{array}{l}\overrightarrow{0} \cong \\
00 \\
00\end{array}$ & $\begin{array}{l}\overrightarrow{0} \hat{0} \\
00 \\
0\end{array}$ & $\begin{array}{c}8 \pm 0 \\
-10 \\
-10\end{array}$ & $\begin{array}{l}5: 7 \\
0: 0 \\
00\end{array}$ & $\begin{array}{l}\text { ô: : } \\
00 \\
0\end{array}$ \\
\hline \multirow{6}{*}{ 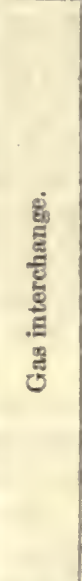 } & \multirow{2}{*}{ 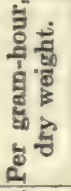 } & $\begin{array}{l}\text {-рәqдоs } \\
-q \varepsilon{ }^{2} \mathrm{O}\end{array}$ & 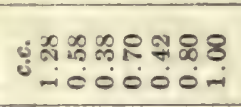 & 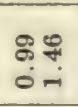 & $\begin{array}{l}1920 \\
912 \\
00\end{array}$ & 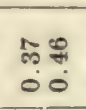 & 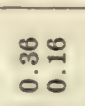 & 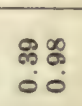 & 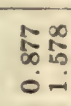 \\
\hline & & 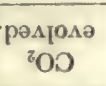 & 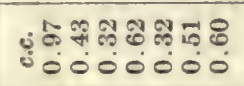 & शึ? श्? & 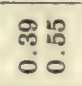 & कृ & $\begin{array}{l}\infty \\
\stackrel{0}{0}=1 \\
00\end{array}$ & $\begin{array}{l}0 \% \\
00 \\
00\end{array}$ & 형 \\
\hline & \multirow{2}{*}{ 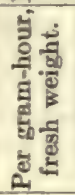 } & $\begin{array}{l}\text { 'pequos } \\
-4 \varepsilon^{2} \mathrm{O}\end{array}$ & 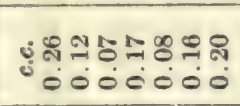 & $\begin{array}{l}\stackrel{9}{9} \overrightarrow{0} \\
0 \\
00\end{array}$ & $\begin{array}{l}0: 0 \\
0: 0 \\
00\end{array}$ & $\begin{array}{l}\infty 8 \\
0.8 \\
00\end{array}$ & $\begin{array}{l}50 \\
00 \\
0\end{array}$ & $\begin{array}{l}\infty \\
0 \\
0 \\
0 \\
00\end{array}$ & 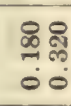 \\
\hline & & $\begin{array}{l}\text { рәлјолә } \\
\text { 'ОО }\end{array}$ & 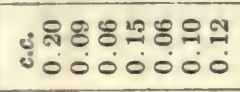 & 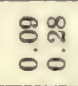 & $\begin{array}{l}5:= \\
0: 0\end{array}$ & $\begin{array}{l}8 \% \\
00\end{array}$ & $\begin{array}{l}\text { 둥 } \\
00\end{array}$ & $\begin{array}{l}108 \\
8 \% \\
00\end{array}$ & 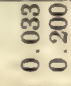 \\
\hline & \multirow{2}{*}{ 哥 } & $\begin{array}{l}\text { pequos } \\
-q^{2} \varepsilon^{2}\end{array}$ & 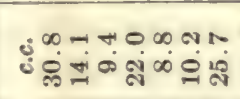 & 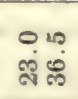 & $\begin{array}{l}\because 0 \\
=\infty\end{array}$ & $\begin{array}{l}\infty \\
\infty\end{array}$ & 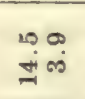 & 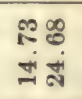 & $\begin{array}{l}+\infty \\
\text { तi } \\
\infty\end{array}$ \\
\hline & & ралјома & 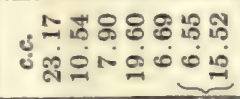 & 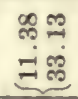 & 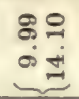 & $\begin{array}{l}\text { 궁영 } \\
\text { 엉 }\end{array}$ & 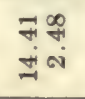 & $\begin{array}{l}5 \infty \\
0 \infty \\
90 \\
90\end{array}$ & 89 \\
\hline \multicolumn{3}{|c|}{ 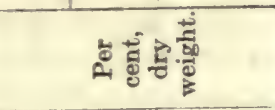 } & 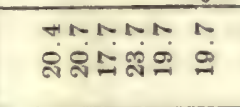 & $\stackrel{0}{9}$ & สิ & $\begin{array}{l}\stackrel{0}{0} \\
\dot{g}\end{array}$ & 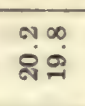 & $\begin{array}{l}0 \infty \\
\text { ลั่ }\end{array}$ & : \\
\hline \multicolumn{3}{|c|}{ 施 } & 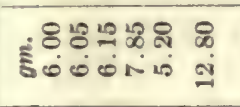 & $\begin{array}{l}\infty \\
\text { is }\end{array}$ & $\stackrel{20}{6}$ & 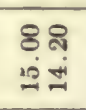 & $\begin{array}{l}8.8 \\
0.9\end{array}$ & $\begin{array}{l}\text { 여 } \\
\text { 19.9 }\end{array}$ & $\stackrel{0}{\circ}$ \\
\hline \multicolumn{3}{|c|}{ 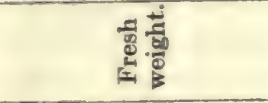 } & 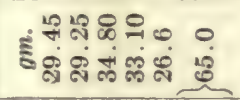 & 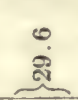 & $\stackrel{-10}{-10}$ & 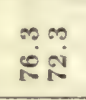 & $\begin{array}{l}\dot{\infty} \infty \\
\infty \infty \\
\infty\end{array}$ & 我 & 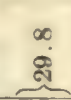 \\
\hline \multicolumn{3}{|c|}{ 离 } & 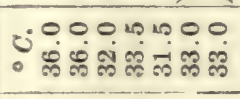 & $\begin{array}{l}100 \\
100 \\
10\end{array}$ & $\begin{array}{l}00 \\
\dot{0}: 0 \\
\infty\end{array}$ & $\begin{array}{l}0: 0 \\
\text { i. } \\
\text { aे }\end{array}$ & 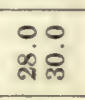 & 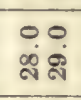 & $\begin{array}{ll}00 \\
0 \dot{0}\end{array}$ \\
\hline \multicolumn{3}{|c|}{ 官出兽 } & 5 & $H 4$ & $H \pi$ & $a=$ & הิt-1 & $a=$ & $H$ \\
\hline \multicolumn{3}{|c|}{ 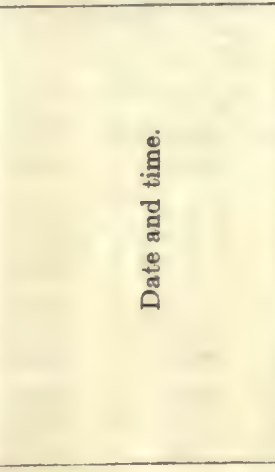 } & 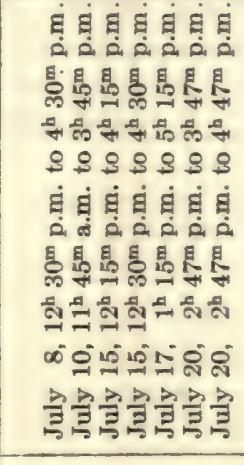 & 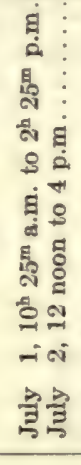 & 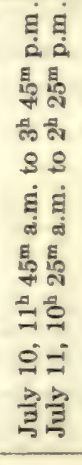 & 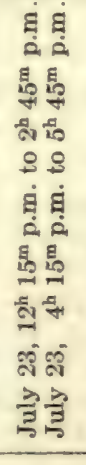 & 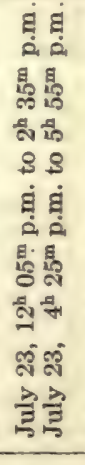 & 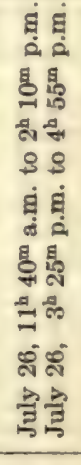 & 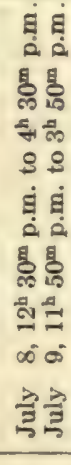 \\
\hline \multicolumn{3}{|c|}{ 席 } & $\triangle 0 A \infty X \bar{x}$ & 居勘 & $\bar{z} \bar{z}$ & జొ & ర్ర్రెల్ర & $z_{z}^{n} \bar{z}$ & $\pm x$ \\
\hline
\end{tabular}


EXPERIMENTAL DATA OF GAS-INTERCHANGE DETERMINATIONS. 89

\begin{tabular}{|c|c|c|c|c|c|c|c|c|c|c|}
\hline 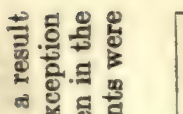 & .97 & & 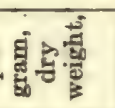 & 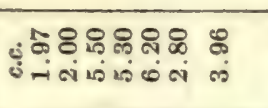 & $\begin{array}{l}\text { ภै: } \\
\text { ஸ่ }\end{array}$ & $\begin{array}{l}\text { 땡요 } \\
\text { ம் }\end{array}$ & 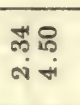 & 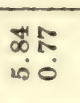 & $\begin{array}{l}\text { t1: } \\
00 \\
00\end{array}$ & $\begin{array}{l}\text { 영 } \\
\text { is }\end{array}$ \\
\hline 要 & 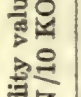 & & 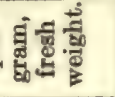 & 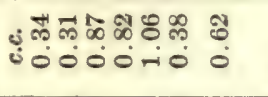 & 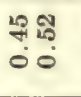 & 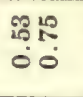 & 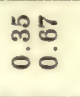 & 용 & $\begin{array}{l}\infty \\
\infty \\
0 \\
0\end{array}$ & i. \\
\hline 동 형 & 近 & & ڤ. & 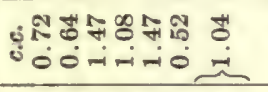 & $\begin{array}{l}\text { Nが } \\
00\end{array}$ & 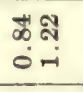 & ㄸำ & 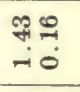 & 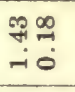 & 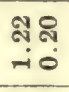 \\
\hline 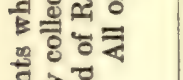 & & $78 \times{ }^{8} \mathrm{O} /$ & ${ }^{8} \mathrm{O}$ & 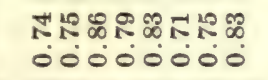 & $\begin{array}{l}8: 2 \\
00 \\
00\end{array}$ & $\begin{array}{l}\text { No } \\
00\end{array}$ & 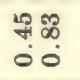 & 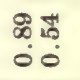 & 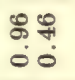 & 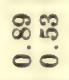 \\
\hline 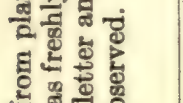 & & 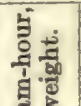 & $\begin{array}{l}\text { prqsos } \\
-q^{z}{ }^{z} O\end{array}$ & 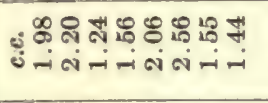 & 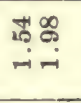 & 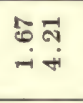 & $\begin{array}{l}\text { 궁요 } \\
\text {-ioi }\end{array}$ & $\underset{-i 0}{S}$ & গ゙ळ & : \\
\hline 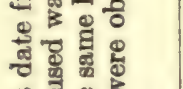 & & 然 & 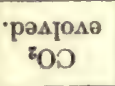 & 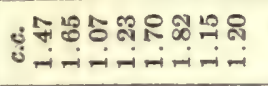 & 둄ำ & $\underset{-\infty}{\stackrel{\text { aิ }}{i}}$ & 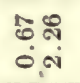 & ஜำ & $\begin{array}{l}\stackrel{0}{\infty} \infty \\
-i 0\end{array}$ & $\begin{array}{l}\text { N.: } \\
0: 0\end{array}$ \\
\hline 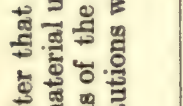 & 递 & 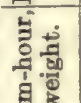 & $\begin{array}{l}\text { pequsos } \\
-q 8^{8} 0\end{array}$ & 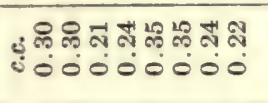 & 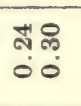 & $\begin{array}{l}\text { aㅗ } 8 \\
\text { a : } \\
00\end{array}$ & $\begin{array}{l}\text { ㄱํำ } \\
\text { ஸั }\end{array}$ & \begin{tabular}{l}
$0 \%$ \\
\hdashline$\%$ \\
00
\end{tabular} & 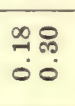 & $\begin{array}{l}\text { 유 } \\
\text { 에 } \\
\text { 00 }\end{array}$ \\
\hline 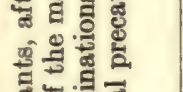 & 兽 & 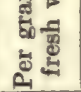 & $\begin{array}{l}\text { "ралјолә } \\
{ }^{2}\end{array}$ & 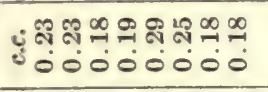 & $\begin{array}{l}\stackrel{7}{\circ} \text { สุ } \\
00\end{array}$ & $\begin{array}{l}25 \\
0.00 \\
0\end{array}$ & $\begin{array}{l}0 \pi \\
00 \\
00\end{array}$ & $\begin{array}{l} \pm 17 \\
00\end{array}$ & $=\stackrel{2}{=1}$ & $\stackrel{52}{0: 1}$ \\
\hline 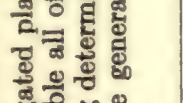 & & छु & $\begin{array}{l}\text { 'peqsos } \\
-q^{2}{ }^{2} O\end{array}$ & 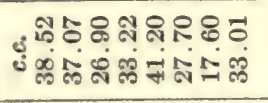 & กั & $=+$ & $\begin{array}{l}\forall 0 \\
\ddot{\infty} \infty\end{array}$ & 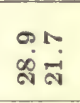 & ๓ุ & 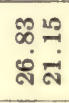 \\
\hline$E+\infty$ & & 룰 & $\begin{array}{c}\text { рәлјолә } \\
\text { "ОD }\end{array}$ & 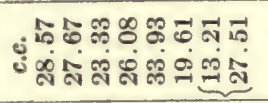 & 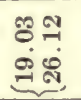 & 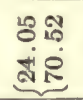 & 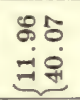 & $\begin{array}{l}18: 2 \\
10=\end{array}$ & $\begin{array}{l}\text { ลิธ } \\
\text { ลे० }\end{array}$ & 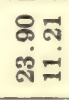 \\
\hline 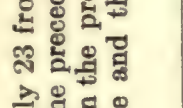 & & क्ष & & 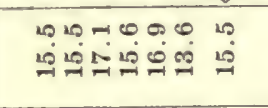 & $\begin{array}{ll}10 \\
19\end{array}$ & 울 & $\stackrel{9}{+}$ & $\begin{array}{l}00 \\
010\end{array}$ & 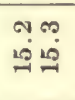 & $\begin{array}{l}\infty 90 \\
290\end{array}$ \\
\hline . & & 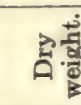 & & 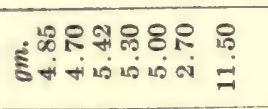 & $\stackrel{4}{\circ}$ & $\frac{18}{4}$ & ำ & $\begin{array}{l}\text { 육워 } \\
\text { 펴 }\end{array}$ & $\begin{array}{l}8: 0 \\
\infty \\
\infty \infty\end{array}$ & $\begin{array}{l}\text { 요 } \\
\text { = }\end{array}$ \\
\hline 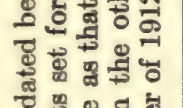 & & 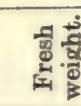 & & 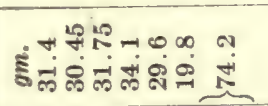 & : & $\overbrace{}^{\circ}$ & 芦 & 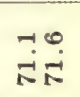 & 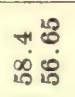 & ió \\
\hline 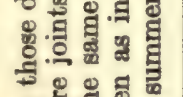 & & है & & ర0\% & மூ & 00 & मृं & 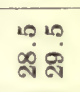 & ค่อ & $\begin{array}{l}00 \\
\infty \\
\infty\end{array}$ \\
\hline & & 它融. & & 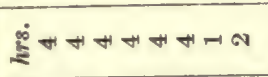 & $H$ & 44 & $A 4$ & $\vec{a}=$ & הN" & $+\infty$ \\
\hline 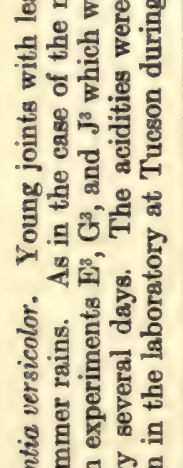 & & 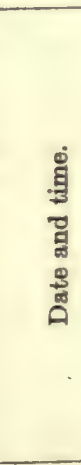 & & 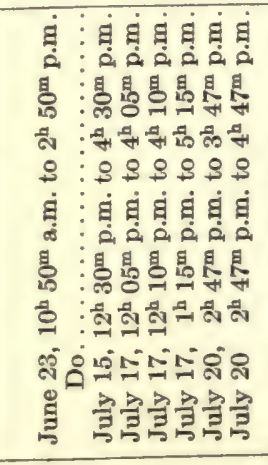 & 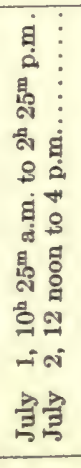 & 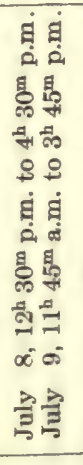 & 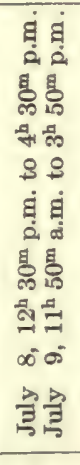 & 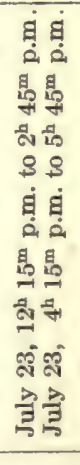 & 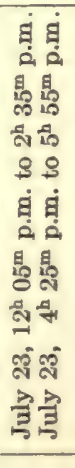 & 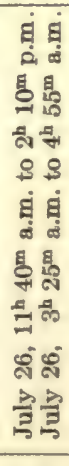 \\
\hline 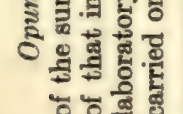 & & 蒙 & & UคณHDEล & 南单 & ઇึ & 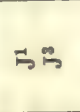 & ค้ดัด & 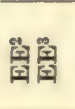 & 幽 \\
\hline
\end{tabular}




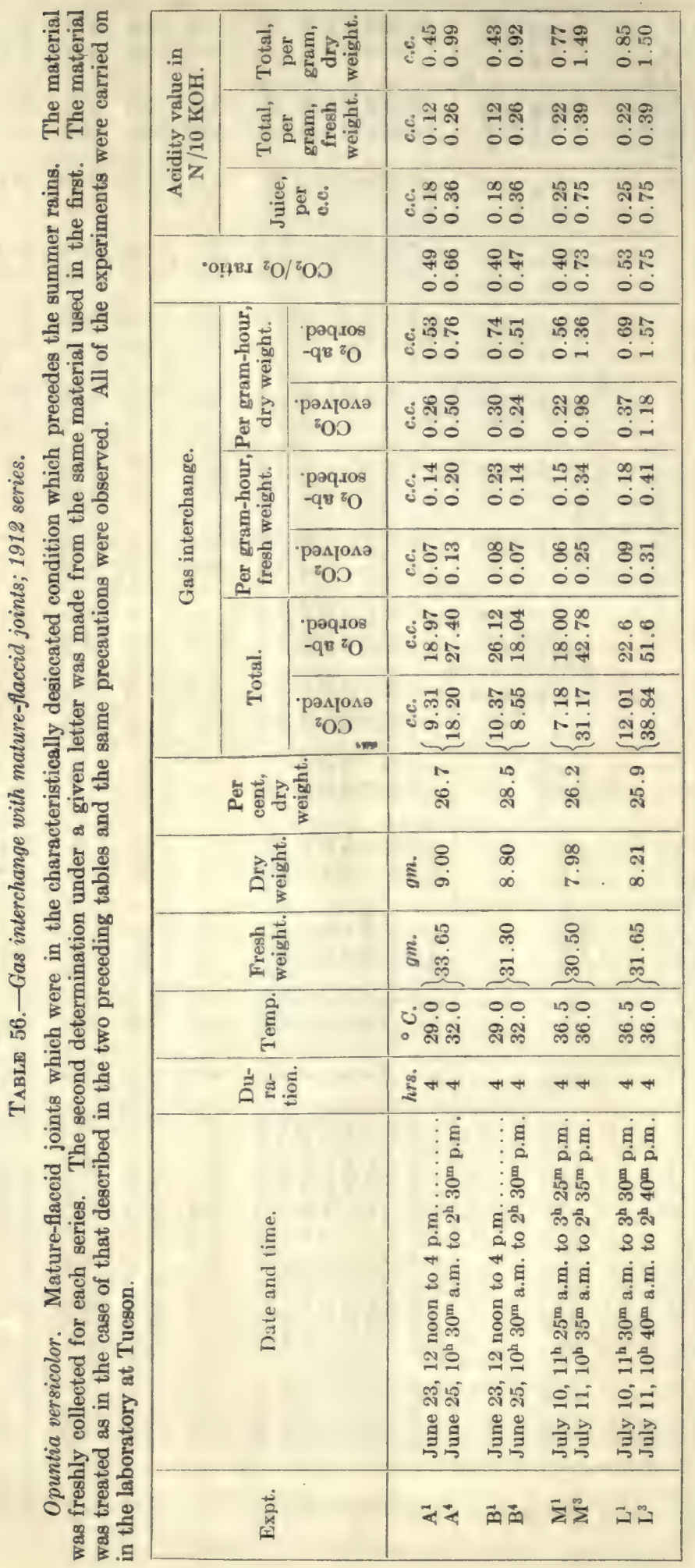




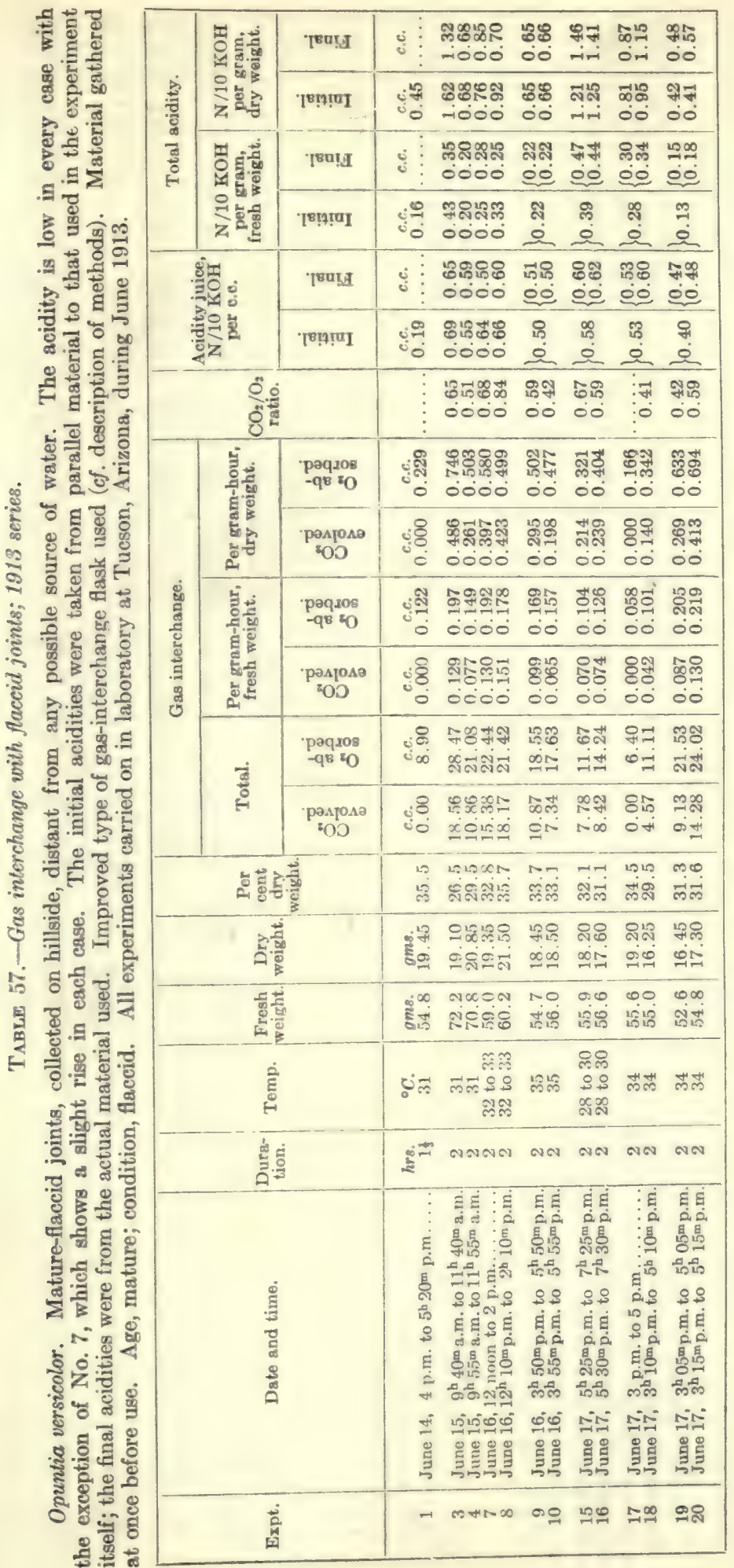


ACIDITY AND GAS INTERCHANGE IN CACTI.

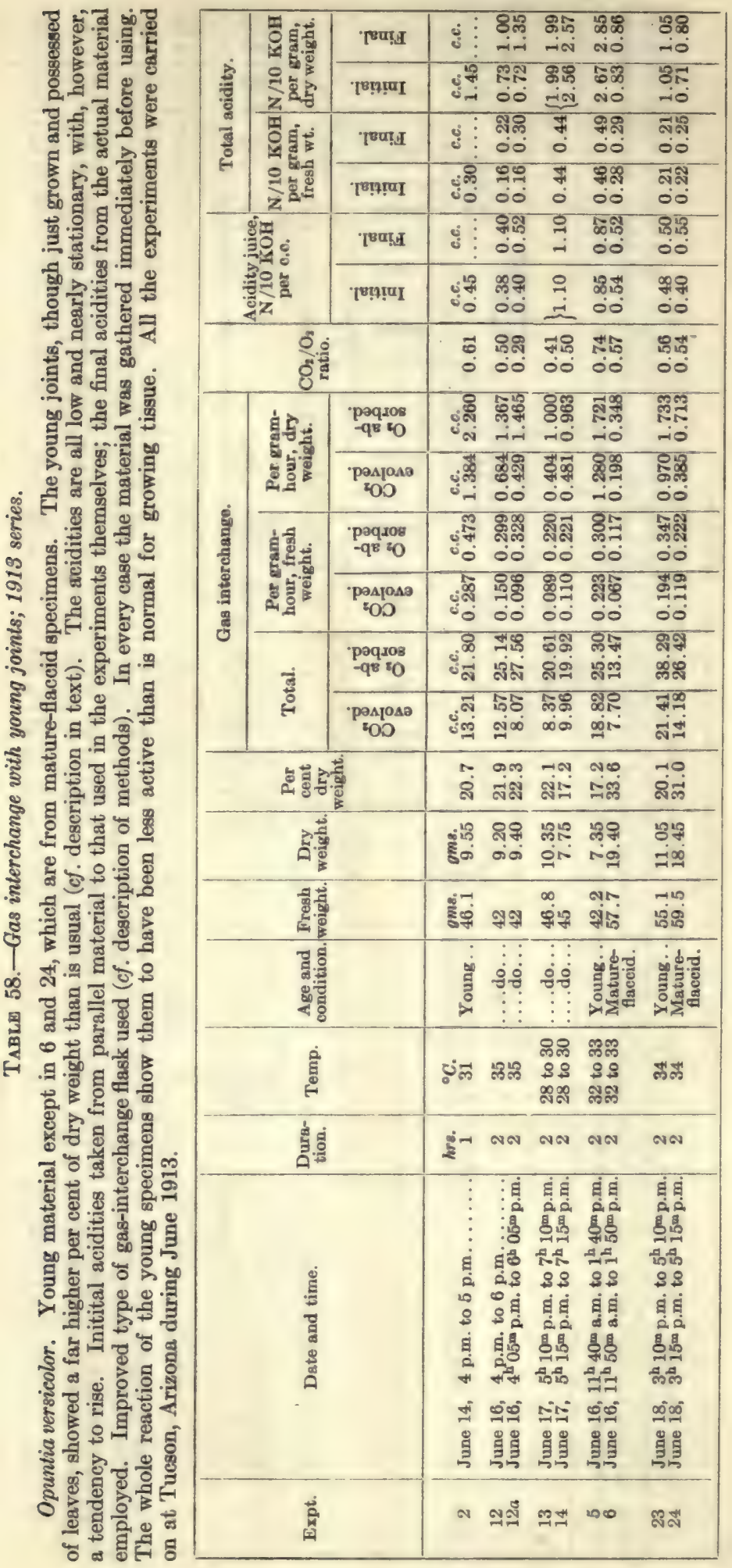




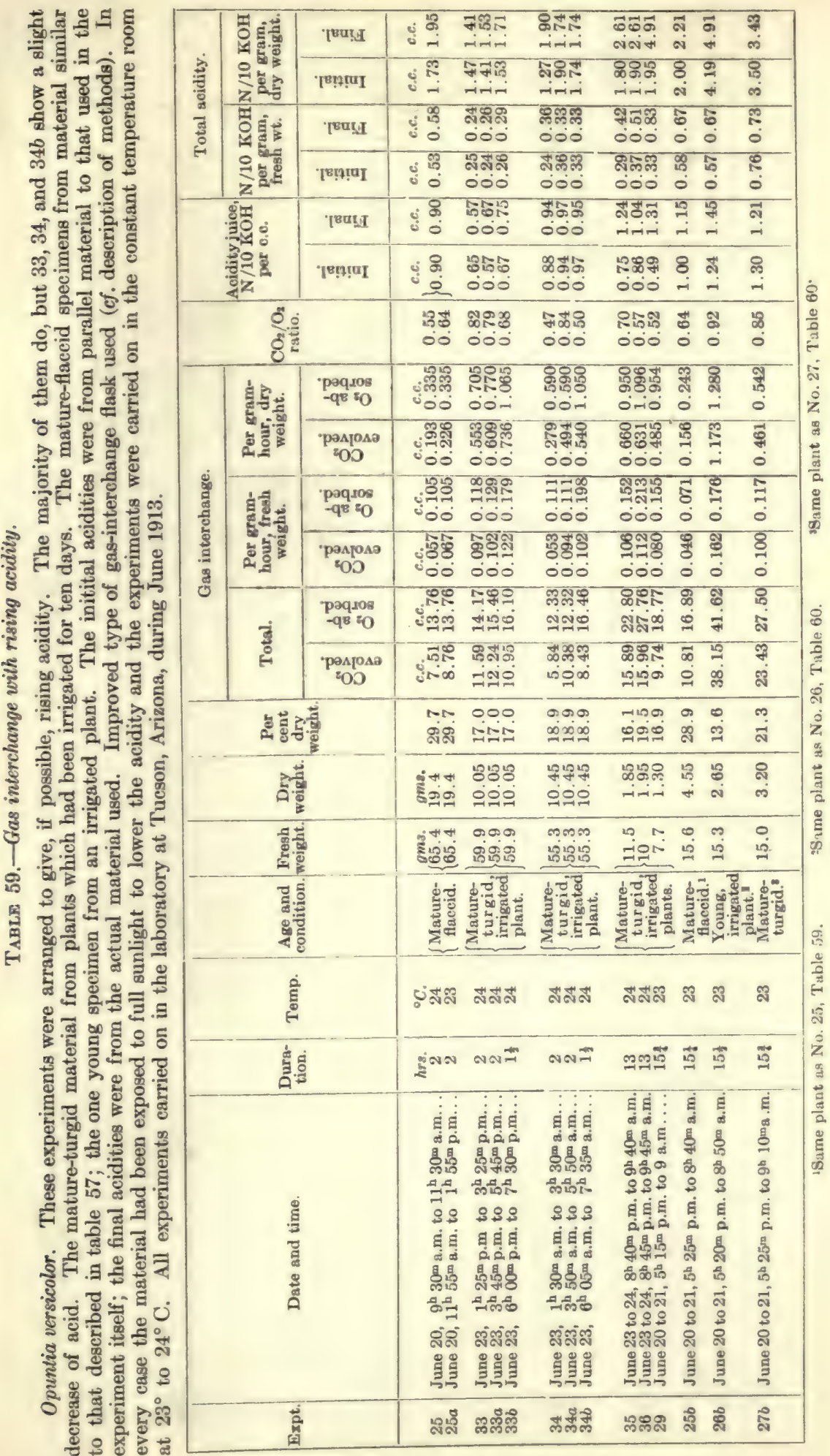




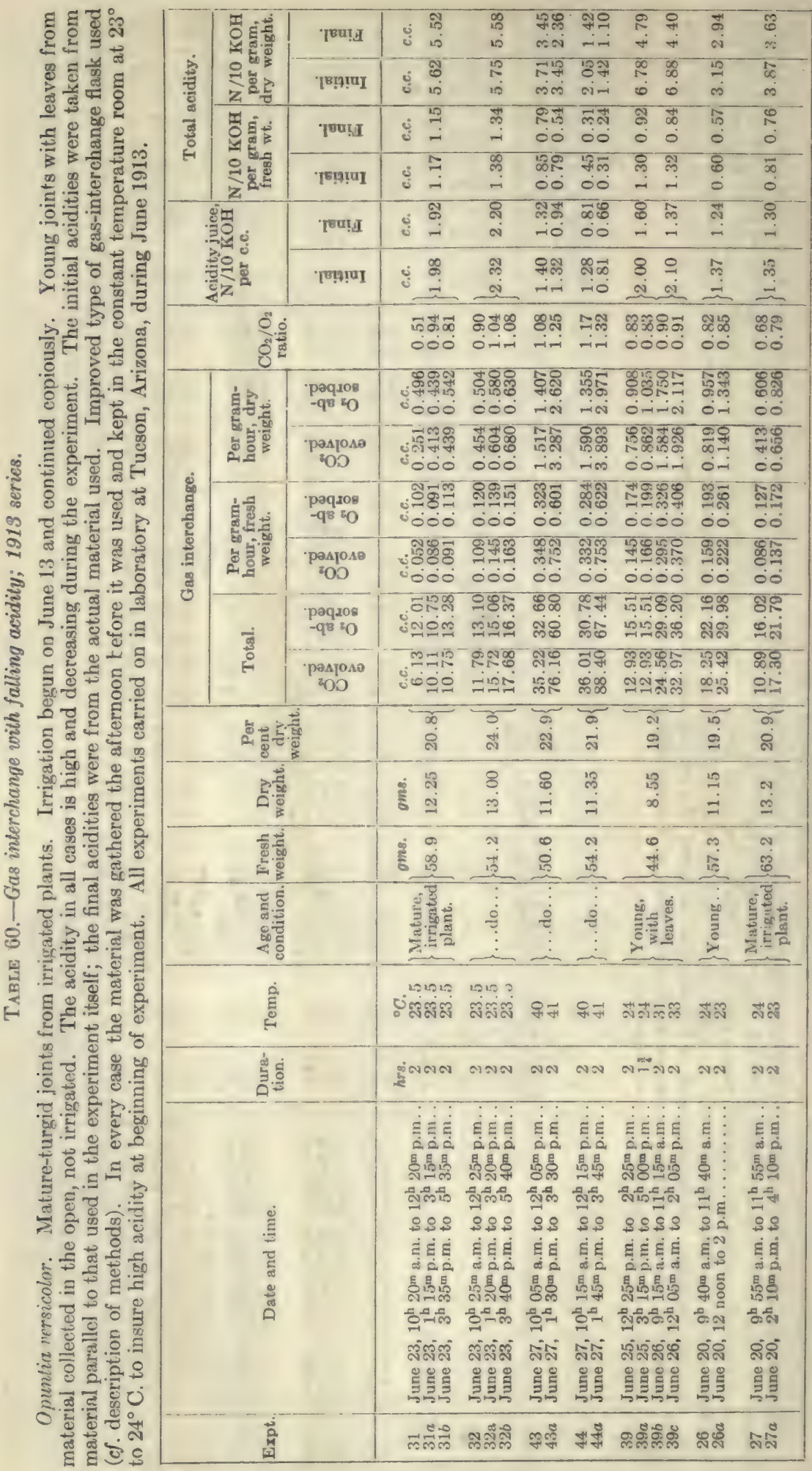


EXPERIMENTAL DATA OF GAS-INTERCHANGE DETERMINATIONS. 95

\begin{tabular}{|c|c|c|c|c|c|}
\hline 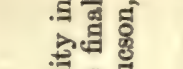 & & 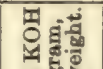 & 'reu!d & 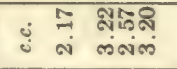 & 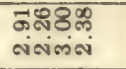 \\
\hline 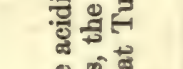 & 胥 & 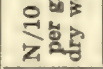 & 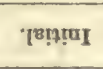 & 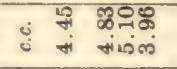 & 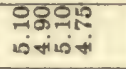 \\
\hline 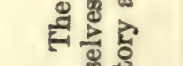 & : & 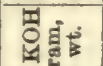 & 'ןणा] & $\begin{array}{c}\text { If } 1070 \\
0 \\
0\end{array}$ & $\begin{array}{l}\text { कालनक } \\
\text { 0000 }\end{array}$ \\
\hline : हี้ & & 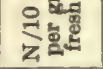 & | & 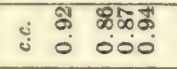 & $\begin{array}{l}\text { कीश\% } \\
0000\end{array}$ \\
\hline 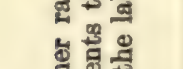 & & 80 & 'ruț & 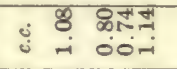 & 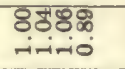 \\
\hline & & 远 & 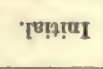 & : & 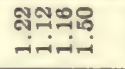 \\
\hline 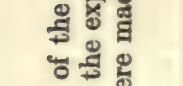 & & & & 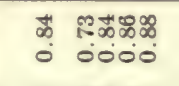 & 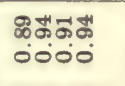 \\
\hline & & & $\begin{array}{l}\cdot{ }^{-p q u x o s} \\
-q 8=0\end{array}$ & 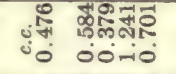 & 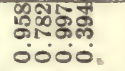 \\
\hline 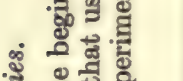 & & 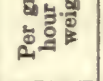 & $\begin{array}{l}\text { PEATOAO } \\
\text { २DD }\end{array}$ & 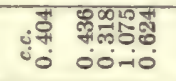 & 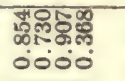 \\
\hline 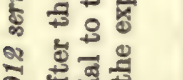 & 魷 & 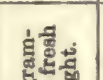 & $\begin{array}{l}\text { 'pequos } \\
-q^{2} \varepsilon_{0}\end{array}$ & 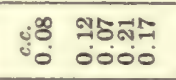 & $\begin{array}{l}\text { 200\% } \\
000\end{array}$ \\
\hline 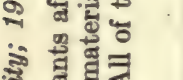 & 量 & 这 & 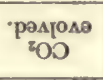 & $\begin{array}{l}880010 \\
050 \\
0000 \\
000\end{array}$ & $\begin{array}{l}97=18 \\
9000 \\
000\end{array}$ \\
\hline हैं & & & $\begin{array}{l}\text { paqros } \\
-q \varepsilon=0\end{array}$ & 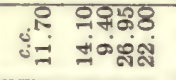 & 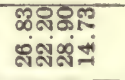 \\
\hline 영 & & : & $\begin{array}{c}\text { pasjosa } \\
\text { "OD }\end{array}$ & 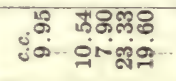 & 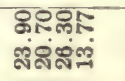 \\
\hline 蛋 & & 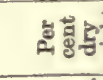 & & 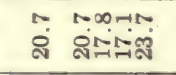 & 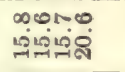 \\
\hline 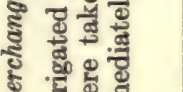 & & 施 & & 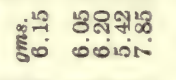 & 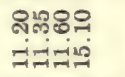 \\
\hline 호욜 & & 题: & & 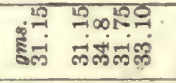 & 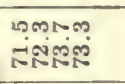 \\
\hline T. & & 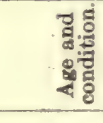 & & 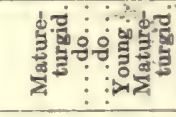 & 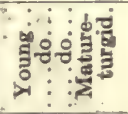 \\
\hline 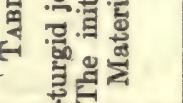 & & : & & பீ口 ศొติ & 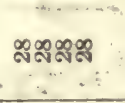 \\
\hline & & 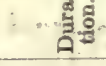 & & 5 & ลतल \\
\hline 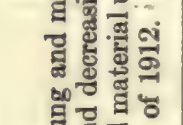 & . & & $\therefore$ & 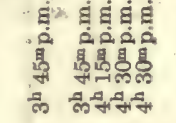 & 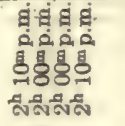 \\
\hline 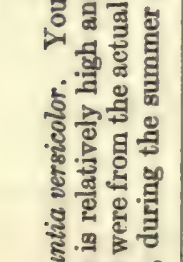 & & 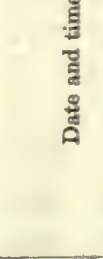 & & 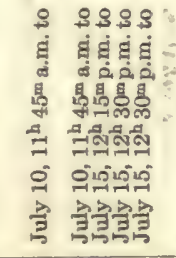 & 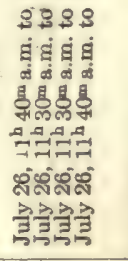 \\
\hline 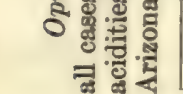 & & 后 & & $\vec{z}$ OR:⿻上丨 & 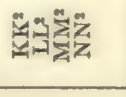 \\
\hline
\end{tabular}




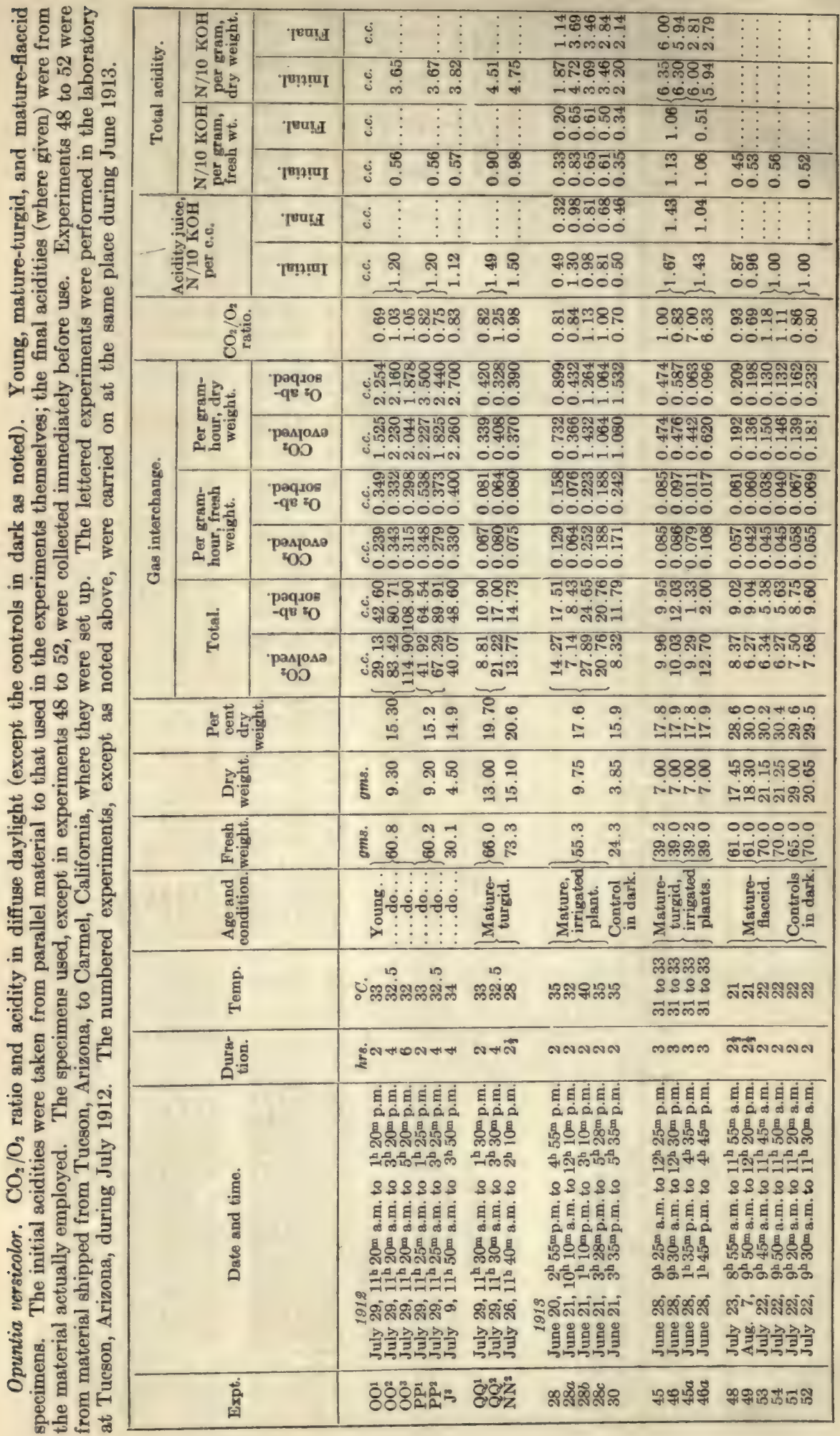




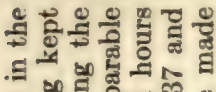
.

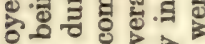

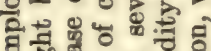
c.

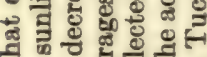
을 ब. 탰ㅇㅎㅇ응 의 क्षे 해웛ㄹ 응

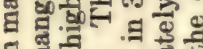
도에

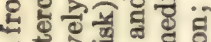
5. 둥

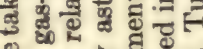

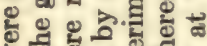
एँ

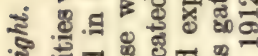

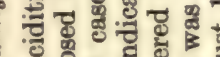
क

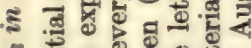
o . 의의

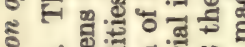

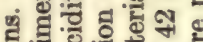
. 드의

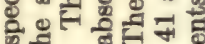

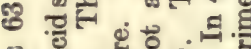

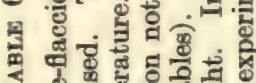
늘 정 형 等

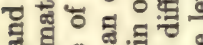
얼

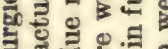

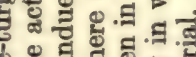

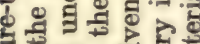

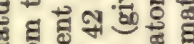

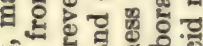
50 o

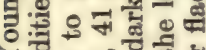

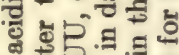
s줄

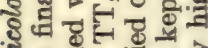

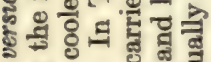

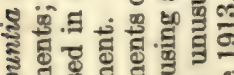
है. 年

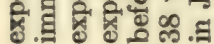

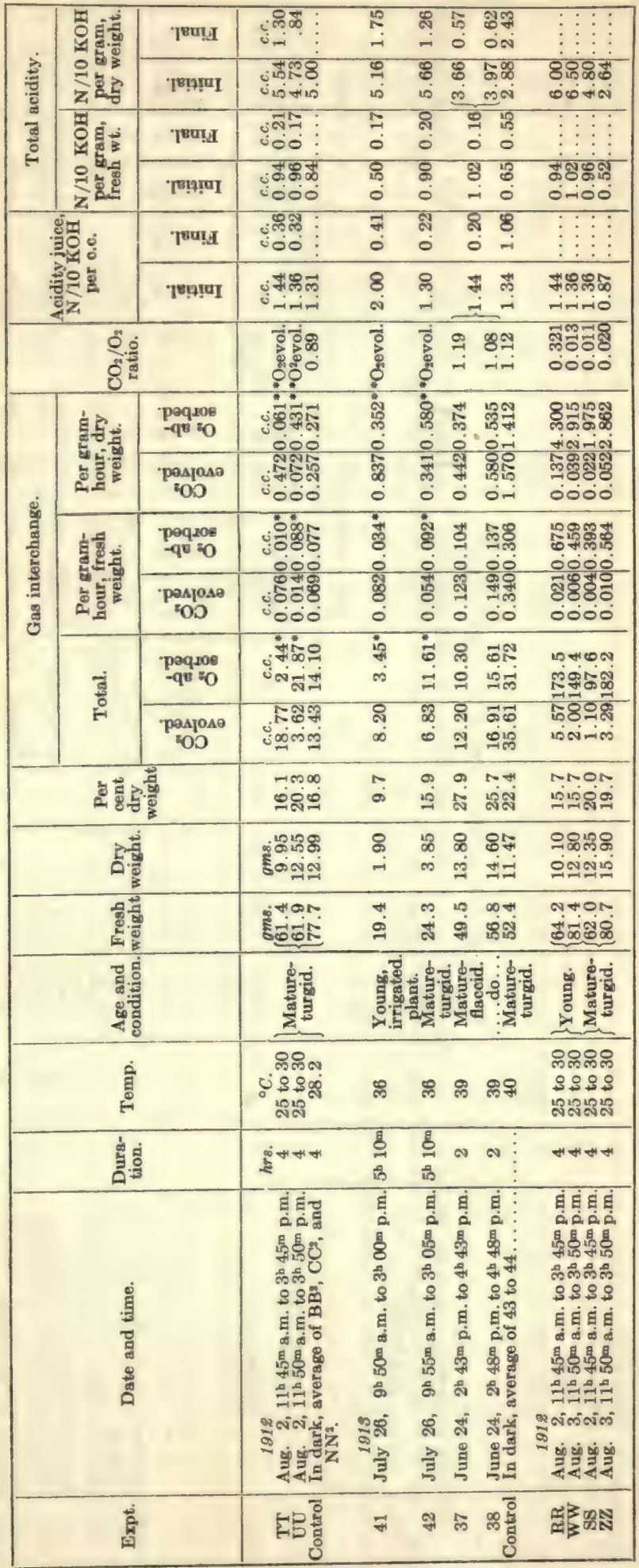




\begin{tabular}{|c|c|c|c|c|c|}
\hline 递 & 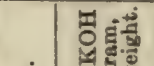 & 'rout & ن & & $\begin{array}{l}\infty \\
\infty \\
0\end{array}$ \\
\hline 害 & 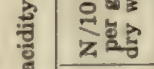 & 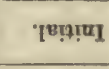 & 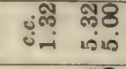 & 2 & $\begin{array}{l}\bar{\infty} \\
0\end{array}$ \\
\hline 宅 & 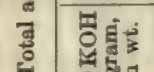 & '[8u!] & 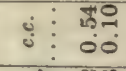 & $\vdots$ & $\begin{array}{l}\stackrel{0}{0} \\
0\end{array}$ \\
\hline कृ & 安忽 & 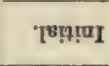 & 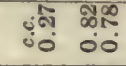 & $\stackrel{0}{0}$ & : \\
\hline 휴응 & 矛晤: & 'ए8u[!] & 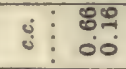 & $\vdots$ & $\begin{array}{l}\text { : } \\
0\end{array}$ \\
\hline 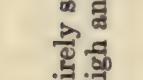 & 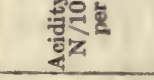 & 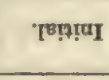 & نำ & $\stackrel{9}{0}$ & $\begin{array}{l}\text { : } \\
0 \\
0\end{array}$ \\
\hline है & 8 & & $\begin{array}{l}\text { of } \\
0 \\
0\end{array}$ & & $\vdots$ \\
\hline हैं & 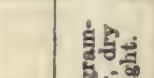 & $\begin{array}{l}\text { peqpos } \\
-q 8=0\end{array}$ & 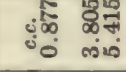 & $\begin{array}{l}\text { सू้ } \\
0\end{array}$ & : \\
\hline & 造 & 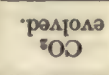 & 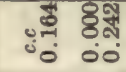 & $\begin{array}{l}8 \\
8 \\
0\end{array}$ & 8 \\
\hline 동 & 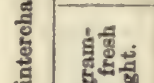 & $\begin{array}{l}\text { paqros } \\
-q 8=0\end{array}$ & 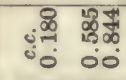 & ฐ్తై & $\begin{array}{l}\infty \\
0 \\
0\end{array}$ \\
\hline 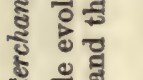 & ठू & 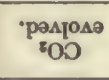 & 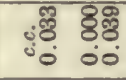 & $\begin{array}{l}8 \\
\\
0\end{array}$ & $\begin{array}{l}8 \\
0\end{array}$ \\
\hline . స్ & ฮี่ & $\begin{array}{l}\text { peqsos } \\
-q^{8}=0\end{array}$ & نั & $\begin{array}{l}8 \\
\infty\end{array}$ & ? \\
\hline 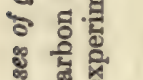 & : & 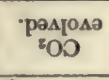 & $\begin{array}{cc}8 & 8 \pm \\
ن-4 & -1 \\
\end{array}$ & $\stackrel{8}{0}$ & 8 \\
\hline है & 岁苨结 & & 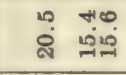 & เి & के \\
\hline 农 & 触 & & $\begin{array}{ll}50 \\
50\end{array}$ & $\stackrel{20}{2}$ & ๙ి \\
\hline 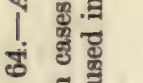 & 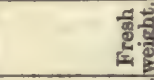 & & ถู่ & $\underbrace{\infty}_{\text {in }}$ & 苗 \\
\hline 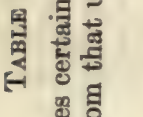 & 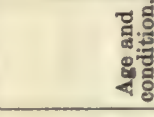 & & 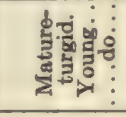 & 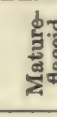 & $\begin{array}{l}\vdots \\
\vdots \\
\vdots\end{array}$ \\
\hline 可 & 家 & & 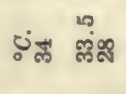 & $\vec{m}$ & \\
\hline 哥 & 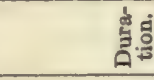 & & है" & $=$ & \\
\hline 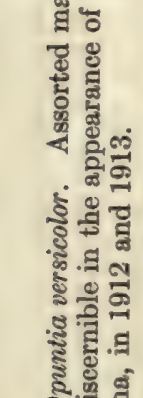 & 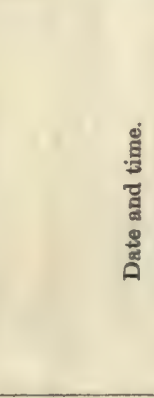 & & 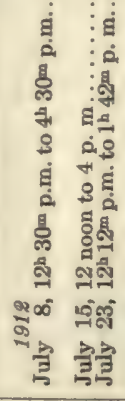 & 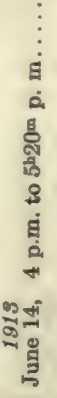 & 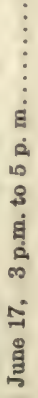 \\
\hline 要 & 总 & & تैق & -1 & $\approx$ \\
\hline
\end{tabular}




\section{EXPERIMENTAL DATA OF GAS-INTERCHANGE DETERMINATIONS. 99}

\section{TABLE 65.-Intramolecular respiration.}

Opuntia versicolor. Young and mature-turgid material, in atmosphere of hydrogen, 99.5 per cent. Only initial acidity given, in terms of c.c. N/10 KOH. For comparison with acidity determinations. Experiments made at Tucson, Arizona, in July 1912.

\begin{tabular}{|c|c|c|c|c|c|c|c|c|c|}
\hline $\begin{array}{l}\text { Experi- } \\
\text { ment. }\end{array}$ & Date and time. & $\begin{array}{l}\text { Gas in } \\
\text { receiver. }\end{array}$ & $\begin{array}{l}\text { Du- } \\
\text { ra- } \\
\text { tion. }\end{array}$ & Temp. & $\begin{array}{l}\text { Fresh } \\
\text { weight }\end{array}$ & $\begin{array}{c}\mathrm{CO}_{2} \\
\text { evolved }\end{array}$ & $\mid \begin{array}{c}\mathrm{CO}_{2} \\
\text { per gram } \\
\text { per hour. }\end{array}$ & $\begin{array}{l}\text { Acidity, } \\
\text { pure } \\
\text { juice. }\end{array}$ & $\begin{array}{l}\text { Condi- } \\
\text { tion. }\end{array}$ \\
\hline FF $^{1}$ & July $23,11^{\mathrm{h}} 40^{\mathrm{m}}$ a.m. to $2^{\mathrm{h}} 10^{\mathrm{m}}$ p.m. & Hydrogen. . & $\begin{array}{c}h r s . \\
2 \frac{1}{2}\end{array}$ & $\begin{array}{l}{ }^{\circ} C . \\
27.5\end{array}$ & $\begin{array}{l}\text { gms. } \\
62.3\end{array}$ & $\begin{array}{c}\text { c.c. } \\
17.20\end{array}$ & $\begin{array}{l}c . c . \\
0.11\end{array}$ & $\begin{array}{l}\text { c.c. } \\
1.31\end{array}$ & Mature \\
\hline $\mathrm{GG}^{1}$ & July $23,11^{\mathrm{h}} 50^{\mathrm{m}}$ a.m. to $2^{\mathrm{h}} 20^{\mathrm{m}}$ p.m. & Air........ & $2 \frac{1}{2}$ & 27.5 & 66.6 & 27.45 & 0.16 & 1.31 & Do. \\
\hline $\mathbf{H H}^{1}$ & July $23,11^{\mathrm{h}} 40^{\mathrm{m}}$ a.m. to $2^{\mathrm{h}} 10^{\mathrm{m}}$ p.m. & Hydrogen. & $2 \frac{1}{2}$ & 27.5 & 63.6 & 40.29 & 0.25 & 1.09 & Young. \\
\hline $\mathbf{J} \mathbf{J}^{\mathbf{2}}$ & July $23,11^{\mathrm{b}} 50^{\mathrm{m}}$ a.m. to $2^{\mathrm{h}} 20^{\mathrm{m}}$ p.m. & Air...... & $2 \frac{\pi}{2}$ & 27.5 & 65.4 & 58.10 & 0.35 & 1.09 & Do. \\
\hline
\end{tabular}

\section{TABLE 66.-Gas interchange and acidity with increased oxygen supply.}

Opuntia versicolor. Similar to other experiments except that a great excess of oxygen was supplied. For comparison with acidity determinations in similar atmospheres. Acidity in terms of e.c. N/10 KOH. Experiment $A$ and $\mathbf{A}^{1}$ were made in New York, the others in Tucson in 1912.

\begin{tabular}{|c|c|c|c|c|c|c|c|c|c|c|c|}
\hline Expt. & Date and time & $\mid \begin{array}{c}\mathrm{Du}- \\
\mathrm{ra-} \\
\text { tion. }\end{array}$ & Temp. & $\begin{array}{c}\mathrm{O}_{2} \text { con- } \\
\text { tent. }\end{array}$ & $\begin{array}{c}\text { Fresh } \\
\text { weight }\end{array}$ & $\begin{array}{c}\mathrm{CO}_{2} \\
\text { evolved. }\end{array}$ & $\begin{array}{c}\mathrm{O}_{2} \text { ab- } \\
\text { sorbed. }\end{array}$ & $\begin{array}{c}\mathrm{CO}_{2} \\
\text { per gm., } \\
\text { per hr. }\end{array}$ & $\begin{array}{c}\mathrm{O}_{2} \\
\text { per gm., } \\
\text { per } \mathrm{hr} .\end{array}$ & $\begin{array}{c}\text { Ratio, } \\
\mathrm{CO}_{2} / \mathrm{O}_{2}\end{array}$ & 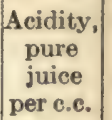 \\
\hline $\begin{array}{l}\mathbf{A} \\
\mathbf{A}^{1} \\
\mathbf{Y Y}\end{array}$ & $\begin{array}{l}\text { Apr. } 18,10^{\mathrm{h}} 45^{\mathrm{m}} \text { a.m. to } 5^{\mathrm{h}} 45^{\mathrm{m}} \text { p.m. } \\
\text { Apr. } 19,10 \text { a.m. to } 2 \text { p.m. } . \ldots \ldots \ldots \\
\text { Aug. } 3,11^{\mathrm{h}} 55^{\mathrm{m}} \text { a.m. to } 3^{\mathrm{h}} 55^{\mathrm{m}} \text { p.m. } \\
\text { July R. T. O. W.12 } \ldots \ldots \ldots \ldots \ldots \\
\text { Aug. } 3,12 \text { noon to } 4 \text { p. m........ }\end{array}$ & $\begin{array}{r}h r s \\
7 \\
4 \\
4 \\
\cdots \\
4\end{array}$ & $\begin{array}{l}{ }^{\circ} C . \\
24.0 \\
24.0 \\
32.0 \\
31.5 \\
32.0\end{array}$ & $\begin{array}{l}\text { p. ct. } \\
72.8 \\
\text { Air. } \\
69.4 \\
\text { Air. } \\
83.5\end{array}$ & $\begin{array}{l}g m s . \\
61.6 \\
61.6 \\
53.7 \\
28.8 \\
53.6\end{array}$ & $\begin{array}{c}c . c . \\
106.8 \\
22.1 \\
85.97 \\
25.74 \\
11.77\end{array}$ & \begin{tabular}{|l|} 
c.c. \\
95.1 \\
31.4 \\
85.97 \\
32.25 \\
12.84
\end{tabular} & \begin{tabular}{l|l}
$c . c$. \\
0.25 \\
0.09 \\
0.40 \\
0.23 \\
0.05
\end{tabular} & \begin{tabular}{l|l} 
c.c. & \\
0.22 \\
0.13 \\
0.40 \\
0.29 \\
0.06
\end{tabular} & $\begin{array}{l}1.12 \\
0.70 \\
1.00 \\
0.79 \\
0.87\end{array}$ & \begin{tabular}{l|l} 
c.c. \\
1.02 \\
1.02 \\
1.08 \\
1.22 \\
0.72
\end{tabular} \\
\hline
\end{tabular}

\section{TABLE 67.-Gas interchange and acidity, over long periods.}

Opuntia versicolor, young and mature-turgid joints. These experiments were run for a long period-18 hours. The $\mathrm{CO}_{2}$ collected in large quantities in the receiver and in all cases was found on analyses of the gas samples to be over 10 per cent and often as high as 20 per cent. In effect the plants were in an atmosphere of increased $\mathrm{CO}_{2}$ content. In other respects these experiments are similar to those given in tables 54 and 55, for which reference may be made for further details. Experiments made at Tucson in June and July 1912.

\begin{tabular}{|c|c|c|c|c|c|c|c|c|c|}
\hline $\begin{array}{l}\text { Ex- } \\
\text { peri- } \\
\text { ment. }\end{array}$ & Condition, date, and time. & $\begin{array}{c}\mathrm{Du}- \\
\mathrm{ra}- \\
\text { tion. }\end{array}$ & Temp. & $\begin{array}{l}\text { Weight } \\
\text { fresh. }\end{array}$ & $\begin{array}{c}\mathrm{CO}_{2} \\
\text { evolved. }\end{array}$ & $\begin{array}{l}\mathrm{O}_{2} \mathrm{ab}- \\
\text { sorbed. }\end{array}$ & $\begin{array}{c}\mathrm{CO}_{2} \\
\text { evolved } \\
\text { per gram } \\
\text { per hour. }\end{array}$ & $\begin{array}{c}\mathrm{O}_{2} \\
\text { absorbed } \\
\text { per gram } \\
\text { per hour. }\end{array}$ & $\begin{array}{l}\text { Ratio, } \\
\mathrm{CO}_{2} / \mathrm{O}_{2} \text {. }\end{array}$ \\
\hline $\mathrm{N}^{2}$ & $\begin{array}{l}\text { Mature-turgid: } \\
\text { July } 10-11,4 \text { p.m. to } 10 \text { a.m... }\end{array}$ & $\begin{array}{c}h r s . \\
18\end{array}$ & $\begin{array}{l}{ }^{\circ} \mathrm{C} . \\
35\end{array}$ & $\begin{array}{l}\text { gms. } \\
31.15\end{array}$ & $\begin{array}{ll}\text { c.c. } \\
65.93\end{array}$ & $\begin{array}{c}c . c . \\
65.9\end{array}$ & $\begin{array}{c}\text { c.e. } \\
0.12\end{array}$ & $\begin{array}{c}c . c . \\
0.12\end{array}$ & 1.00 \\
\hline $0^{2}$ & 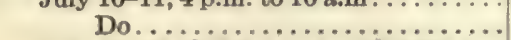 & 18 & 35 & 29.25 & 64.39 & 67.4 & 0.12 & 0.13 & 0.95 \\
\hline $\mathbf{P}^{2}$ & July $15-16,4^{\mathrm{h}} 30^{\mathrm{m}}$ p.m. to $10^{\mathrm{h}} 30^{\mathrm{m}}$ a.m. . & 18 & 32 & 34.8 & 31.36 & 42.5 & 0.05 & 0.07 & 0.74 \\
\hline $\mathbb{s}^{2}$ & Do $\ldots \ldots \ldots \ldots$ & 18 & 32 & 33.1 & 115.20 & 119.0 & 0.15 & 0.17 & 0.97 \\
\hline $\mathrm{X}^{2}$ & $\begin{array}{l}\text { July } 17-18,5 \text { p.m. to } 11 \text { a.m.......... } \\
\text { Young: }\end{array}$ & 18 & 32 & 26.6 & 37.47 & 41.6 & 0.08 & 0.09 & 0.92 \\
\hline $\mathrm{G}^{2}$ & July $8-9,5^{\text {h }} 30^{\mathrm{m}}$ p.m. to $11^{\mathrm{h}} 30^{\mathrm{m}}$ a.m.... & 18 & 35 & 30.9 & 100.0 & 116.9 & 0.18 & 0.21 & 0.86 \\
\hline $\mathrm{J}^{2}$ & Do $\ldots \ldots \ldots \ldots$ & 18 & 35 & 30.1 & 129.3 & 147.1 & 0.24 & 0.27 & 0.88 \\
\hline $\mathbf{R}^{2}$ & July $15-16,4^{\mathrm{h}} 30^{\mathrm{m}}$ p.m. to $10^{\mathrm{h}} 30^{\mathrm{m}}$ a.m. . & 18 & 32 & 31.75 & 111.0 & 114.6 & 0.19 & 0.20 & 0.96 \\
\hline $\mathrm{U}^{2}$ & June $17-18,4$ p.m. to 10 a.m......... & 18 & 32 & 29.6 & 124.21 & 127.8 & 0.23 & 0.24 & 0.96 \\
\hline$W^{2}$ & June $17-18,5$ p.m. to 11 a.m......... & 18 & 32 & 19.8 & 109.41 & 121.5 & 0.31 & 0.34 & 0.90 \\
\hline
\end{tabular}




\section{SUMMARY AND CONCLUSIONS.}

It is obvious that where so many variables are concerned as are presented in the problems of the acidity and respiration of the cacti it becomes a difficult matter properly to evaluate the results obtained. It will be well to summarize briefly the main points which have been brought out before attempting any general discussion.

In all previous work upon the succulents, the cactus forms have not been utilized as much as other types, which, indeed, is not remarkable considering that no adequate supply of material could have been easily available. Had not de Saussure's original observations on the anomalous gas interchange of fleshy plants been made upon an Opuntia they might not have been used at all.

Regarding these problems of acidity and gas interchange the following categorical statements may be made, some of which cover facts previously known.

1. With rising acidity the total amount of acid in the tissues increases more rapidly than does the concentration of the juice. The carbon dioxide production with rising acidity is relatively small, while the oxygen absorption is large; hence the $\mathrm{CO}_{2} / \mathrm{O}_{2}$ ratio is low.

2. Light is the most important factor in the diurnal decrease of acidity, but is less effective at low temperatures than at high ones. At higher temperatures carbon dioxide is given off from the plant even in direct sunlight, as also is oxygen. In diffuse light, carbon dioxide is produced in larger quantities and oxygen is still absorbed. Dry joints absorb oxygen even in sunlight.

3 . Rising temperature, especially above $30^{\circ} \mathrm{C}$., causes a decrease in acidity when the latter is already high, but does not wholly inhibit the accumulation of acid when near or at its minimum. With an increased evolution of carbon dioxide due to rising temperature the $\mathrm{CO}_{2} / \mathrm{O}_{2}$ ratio rises, since a corresponding amount of oxygen is not absorbed. There is a lag in the response of carbon dioxide evolution with both rising and falling temperatures.

4. Acidity declines when the oxygen-supply is much above the normal and tends to rise to a certain extent when the plant is deprived of that gas, provided that the temperature is not too high. In an excess of oxygen the $\mathrm{CO}_{2} / \mathrm{O}_{2}$ ratio rises; in its absence the ratio remains stationary or decreases.

5. Wounding causes a noticeable decrease in acidity, the amount being proportional to the extent of the injury. Like other cases of decreasing acidity, this implies an increased evolution of carbon dioxide and a consequent raising of the gas-interchange ratio. The maximum evolution of carbon dioxide is attained 24 hours after injury, slowly decreasing to the fourth day, when it is again normal. The traumatic effect of the mere removal of a joint from the plant is not sufficient to constitute an error for experimental purposes.

6 . Except in very young tissue which has the maximum acidity, the acidcontent and concentration do not vary greatly with age. The slightly lower total acidity in 3-year-old turgid joints is due probably to the increase in the thick-walled prosencyhmatic tissues rather than to actual decline in the acid content of the parenchymatic cortex, since the concentration of the juice is practically the same in the 1-year old tissue. The flaccid joints have a generally lower acidity. The actual rate of the production of carbon dioxide is greatest in the youngest tissues, next in the old turgid joints, and least of all 
in the flaccid ones. The gas-interchange ratios vary according to the acidity conditions rather than according to the age of the tissue.

7. In general, high acidities, high rate of evolution of earbon dioxide, and high $\mathrm{CO}_{2} / \mathrm{O}_{2}$ ratios are associated and the reverse of this statement is true.

8. No difference in acidity was found between the base and the tip of a joint, but the major portion of the acid is held in the layers of soft, highly turgid cells outside of the bundle ring.

The rise and fall of acidity, as far as external conditions are concerned, seems to be influenced mainly by two factors: light, which is the most important, and temperature which, while it plays a secondary rôle, is by no means to be neglected. In the daytime, particularly during the brilliant and hot days that are characteristic of the native climate of the cacti, both of these factors are in an optimal condition for the processes of de-acidification. Consequently, the diurnal acidity curve follows closely the diurnal temperature curve, but lags behind it by about an hour and must also be fairly close to that of diurnal light intensity. At night not only is light absent, but also the temperature is lower, and in the arid regions inhabited by these plants the difference between night and day temperatures is very marked with a consequent accumulation of acid. This relation to light and temperature is so intimate that changes in the intensity of either are quickly reflected in the acidity of the tissues. After a cool night the acidity is measurably higher than after a warm one, and a cloudy day greatly reduces the rate of de-acidification. Such being the case, the degree of acidity in any one plant varies greatly from day to day. Photolytic action is unquestionably the most powerful factor in the fall of acidity.

That the water-content of the tissues appears to increase somewhat more rapidly than does the total acid present, in consequence of which the increase in the concentration of the juice lags behind, is a point of some interest. It has already been noted that there might be applied here the idea brought out by Borovikow concerning the increased hydratative power of acidified colloids. Under such conditions as he postulates, water which might otherwise be transpired is held in the tissues. Also it may be remarked that the increase of acids in the vacuoles might well increase the turgor pressure which in a measure would act in the same way.

That acidity declines in an excess of oxygen does not seem surprising, notwithstanding the statement of Astruc that an increased partial pressure of the gas is favorable for acid formation. Both the accumulation and loss of acid are undoubtedly oxidation phenomena, but under ordinary circumstances oxygen is more essential to the latter than to the former process. That there should be even a slight rise in acidity with a complete or partial absence of oxygen is a matter of some surprise. Under such conditions the rise is, indeed, slow and is not very great compared with that found in normal air, but it is a definitely marked one. Since the acids are themselves the product of a partial oxidation of substances in the cells, the question arises how can they be formed when oxygen is absent. The explanation must be that acids are also formed in the course of "intramolecular respiration." This would not, indeed, be wholly in accord with some of the prevalent ideas regarding the phenomenon, but at the same time it is hard to see why the auto-oxidations of the protoplasm might not yield, in some measure at least, end-products 
besides carbon dioxide, which are similar to those formed by normal respiration. Presumably, the acid found in the tissues exposed to atmospheres devoid of oxygen is the same as under normal conditions, but of this we have no proof. In connection with this question it should be determined if alcohol is produced by the "intramolecular respiration" of cacti, as appears to be the ease in all other plants in the absence of oxygen, but since the normal result of partial oxidation in the cacti seems to be malic acid, their behavior under these conditions may be quite different from that of the ordinary plant.

According to Spoehr, in the paper already referred to, ethyl alcohol must be the first degeneration product of malic acid when exposed to light in the presence of oxygen. This then passes over by further oxidations to acids which become successively simpler. Looked at from this standpoint, it would seem as if the normal respiration of the cacti were of the nature of what is commonly called intramolecular, except that the process is not carried far enough to yield alcohol, but stops at malic acid. Alcohol is now commonly recognized as an accompanying result of intramolecular respiration in forms that have sugars at their disposal. Such an interpretation is in accord with the idea already largely entertained, namely, that the respiratory activity of succulents is influenced by the insufficient oxygen supply of the tissues. It is plain, however, that in this connection an investigation should be made into the nature of the gases held in the tissues of these plants. Such knowledge might throw further light upon the question.

That the acids are formed by reason of the comparative lack of oxygen in the massive tissues of the succulents has been the conclusion of many investigators. This interpretation has much to recommend it and is supported both by the behavior of the cacti in the absence of oxygen as well as by their behavior in the presence of an excess of that gas. That the acids are the only end product of this respiration is not necessarily the case-nor indeed, probably sofor some carbon dioxide is evolved even when the tissues are gaining in acidcontent. If we were informed of the exact nature of the substances consumed in the first place, it might be possible to estimate how large a percentage of the actual energy-releasing processes this oxidation to acid represents. It is safe to say that it is the major part. It may be said, in this connection, that in these experiments there were very few cases-only one or two-where there was a complete absence of the evolution of carbon dioxide in the dark. These cases, moreover, were anomalous in other respects. Whether the relatively small residual output of carbon dioxide was from oxidations resulting from contact with free oxygen or arose as did the carbon dioxide of intramolecular respiration would be difficult to determine. It would be necessary to ascertain the exact amount of oxygen required to produce the malic acid found from the materials at the disposal of the cells and then to see how it compared in quantity with the actual amount of oxygen absorbed. In such a way it could then be decided whether the carbon dioxide given off when the acidity is rising is produced in an aerobic or an anaerobic fashion.

In the opinion of the writer the accumulated acid, together with whatever carbon dioxide is evolved during the process of accumulation, represents the end-products of the respiratory activity, if we exclude the metabolic water which must also be formed. But the respiratory activity is by no means the direct cause of all of the carbon-dioxide which may be given off. A considerable portion, and under some conditions by far the largest portion of this gas, 
is the result of the deacidification, which does not seem to be connected with the actual vital processes. The breaking down of the acid by sunlight is an unavoidable consequence of its accumulation in the tissues and does not seem to be connected with the energy-releasing reactions which are of a true respiratory nature.

Carbon-dioxide evolution as a whole, while not so great as in more typical plants, is by no means as small in the cacti as is commonly supposed. Carbondioxide evolution as representing true katabolic activity is probably much less. In estimating its output it is of course impossible to say, except by inference, how much of the gas is from the latter source and how much simply from the splitting of the stored acids.

By both the methods which were used it was found that the newly formed joints have a much higher rate of carbon-dioxide formation, which is probably due as much to the increased amount of acid stored as to any other cause. If activity is to be measured in terms of this sort, the mature-turgid joints are much less active than the young tissue and the mature joints which are desiccated are still more quiescent, but not by any means in what could properly be called a resting-state. The proportional relation of carbon-dioxide evolution in the three conditions of the tissues is represented by the ratio $6: 3: 2$. The relatively slight decrease in the rate in mature-flaccid joints, as compared with the mature-turgid ones, when considered in connection with the fact that their acidity is much lower than the more active tissues, again suggests that the relation between respiration in the proper sense and de-acidification is not as close as has been assumed.

Increased heat hastens the production of carbon dioxide 100 per cent or more for every $10^{\circ}$ increase, thus conforming measurably to the principle of van't Hoff regarding the acceleration of chemical reactions by rise in temperature. However, since the absorption of oxygen does not increase as rapidly, the gas-exchange ratio with oxygen naturally rises under these conditions, which only goes to support the idea that a considerable part of the increased evolution of carbon dioxide is not truly a result of the respiratory function.

The maximum carbon-dioxide formation is at $45^{\circ} \mathrm{C}$. and from this point there is a gradual decrease as the temperature rises. It is, however, questionable if at the high temperatures of $60^{\circ}$ to $65^{\circ} \mathrm{C}$. the continuance of an evolution of carbon dioxide may not be wholly due to destructive processes not properly respiratory. High temperatures in the presence of oxygen result in the decrease of acid in the living plant, and it is possible that there may be some katalytic agent present which initiates this action even in the absence of light. Were it not for the evidence which Spoehr has brought forward the presence of some enzyme might be suspected. Finally it may be added that some of the carbon dioxide exhaled might be due to gas dissolved in the cell fluids which the high temperature drives off.

"Intramolecular respiration" is relatively high in these plants. If the amount of carbon dioxide evolved under normal conditions be taken as 100 , then in the absence of oxygen the quantity at $23^{\circ} \mathrm{C}$. is 66 and at $35^{\circ}$ is 85 . That there is proportionally so large an amount of the gas produced does not seem to be due to deacidification, for as we know acidity does not fall rapidly in the absence of oxygen and it may rise. As has been pointed out, however, it is not impossible that the preliminary stages of deacidification which involve the formation of simpler acids than malic may be going on, so that when the 
acid is determined in toto by titration, no decrease in acidity would show. To determine if this be true, it would be necessary to investigate the precise nature of the acids present when the conditions are normal and to make a comparison with those found in the absence of oxygen.

When the oxygen-supply is increased rather than diminished the question arises what may be the relation of the interchange of oxygen and carbon dioxide. The actual amount of both is measurably increased, but the latter more than the former, so that the ratio naturally rises also. As we have seen, increased oxygen supply hastens deacidification and it may very well be that the major portion of the accelerated carbon dioxide production is due simply to the splitting of the acid and is not a proper respiratory reaction. It has been shown in other plants that increased oxygen supply is not accompanied by a correspondingly large increase in carbon dioxide output, a fact which supports the above opinion. Furthermore this interpretation is in keeping with all the experiments recorded here, in which falling acidity is concerned, where the $\mathrm{CO}_{2} / \mathrm{O}_{2}$ ratio has been shown usually to be high.

That a high $\mathrm{CO}_{2} / \mathrm{O}_{2}$ ratio is accompanied by a high acidity which is falling, and that the reverse is true with low acidity that is rising, are no more than would be expected, since we know that the breaking down of malic and other related acids is attended by the evolution of earbon dioxide without a corresponding absorption of oxygen, whereas their formation is accompanied by the absorption of oxygen without the evolution of any gaseous waste product. There is strong support for the interpretation that exhaled carbon dioxide may arise from sources other than that of a true respiratory process in the case of falling acidity, for even at normal temperatures the organic acids which are concerned can be split to simpler forms with the evolution of this gas without any activity of living protoplasm. In deacidification the initial acid-content of the tissues bears a relation both to the amount of carbon dioxide produced and to the gas interchange ratio. With the greatest amount of acid there is also the greatest production of carbon dioxide, which, as it is not accompanied by a similar increase in the absorption of oxygen, leads to the highest $\mathrm{CO}_{2} / \mathrm{O}_{2}$ ratio; and as the acidity diminishes there is commonly a corresponding decrease in the evolution of gas and in the ratio.

If the amount of water contained in the tissues is large, the juice itself may be relatively weak, although the total acid-content is great. Increase of juice concentration, which is not always, though usually, accompanied by a proportional increase in total acidity, is likewise correlated with high ratios, though the effect is not so well marked. In other words, while deacidification seems to take place rather more rapidly when the juice concentration is high than when it is low, the actual amount of total acid present is more important in determining the rate of carbon dioxide production and the gas ratio.

The phenomena connected with rising acidity are also in accord with what has been said above. The oxygen which is absorbed is used largely in the partial oxidations which lead to the formation of malic acid, though there is also a residual carbon dioxide evolution that is always present. The major portion, then, of the energy release which results from the aerobic respiration would seem to be connected with the formation of this acid. The question of the possible source of the residual carbon dioxide has already been discussed. It seems gratuitous to maintain, as does Nathansohn, that the breaking-down of the acids is simply a continuation of the ordinary respiration processes, 
begun when the original malic acid was formed. It is hard to see why in the succulents the respiration should depend so largely upon the action of sunlight when such is certainly not to be regarded as the case in the vast majority of plants. It may be urged that we have acids in the tissues of practically all plants and that in the presence of light these acids behave in a fashion similar to that in the succulents, so that such processes are not peculiar to the fleshy forms. However, in the ordinary plant the amount of carbon dioxide production is large in proportion to the amount of acids found in the leaves, so that in any case the latter could not cut much of a figure in respiration.

It is as if when malic acid is formed a certain, and in the succulents a very large, portion of the available food material were side-tracked out of the line of the usual katabolic processes. Their further oxidation not taking place rapidly, they accumulate in the tissues during the night, only to be destroyed during the day by the action of light. As has been said before, the malic or other acids may reasonably be supposed to exist as such in the vacuole and are not to be regarded as in any intimate connection with the active protein, but rather to be removed from the immediate sphere of protoplasmic activity.

It is true that some deacidification occurs in the absence of light or under high temperatures when the initial acidity is high, and consequently it may be maintained that malic acid is utilized as a source of energy. That this utilization of the malic acid should occur under such circumstances does not seem to influence the general question. It may well be that in the prolonged absence of light, when the more readily available substances have been disposed of, the malic acid is attacked. Or in the case of high temperature, practically the same thing happens, but more quickly, as the increased heat causes a more rapid consumption of the food material. However, the katabolic disintegration of malic acid is ordinarily not considerable and consequently it collects at night, only to be broken down by the light during the daytime, but not in connection with the protoplasm itself. According to the writer's point of view, it would be necessary for the malic acid to form some union with the living protein, just as sugar probably does, before the energy released in its breaking down could avail the plant.

The question of the evolution of carbon dioxide while under the illumination of even direct sunlight, despite the photosynthetic processes which are going on under such conditions, is a matter of particular interest. In the cases examined there seems to be a greater production of this gas under these conditions than has previously been reported. In diffuse light the rate of carbon dioxide evolution is considerable and some absorption of oxygen is still going on. It is apparent, then, that in such relatively weak illumination the photosynthetic activity must be feeble. In direct sunlight there is still some formation of carbon dioxide, but it is much diminished. The oxygen, however, ceases to be absorbed in the young and in the mature-active tissue or may even be evolved, though in the mature-flaccid plants the intake of the gas continues in even full sunlight. In the last case it may be asked if photosynthesis is not practically suspended, as indeed is indicated by the condition of the chlorophyll, which is usually yellowish rather than green in color. Under any circumstances, however, there must be an actual loss of weight even in the sunlight. Such a phenomenon could not persist if the plant is to maintain itself for any length of time, let alone to grow. It may be that the actual accumulation of energized substance on which the cactus lives and grows takes place during the 
summer only at the cooler part of the day, or it may take place mainly at the cooler time of the year, when, by reason of the lower temperature and somewhat diminished intensity of the sunlight, the breaking-down of the acids is less. At such times the photosynthetic activity of the plant is able to more than utilize all the carbon dioxide which is evolved in the processes of deacidification. Such a relatively restricted period during which the eactus is actually gaining in substance would mean a slow accumulation of stored energy and might account for the relatively slow growth of the plant. The first expansion of the young joints in Opuntia versicolor is, it is true, rapid, so rapid indeed that it must be accomplished on the basis of material already accumulated, but after the first growth the increment is very gradual. In this species the formation of new joints takes place during the summer rains, a period of high temperature and ample water-supply, and, if the above is true, on the basis of the potentital energy stored during the previous spring. This whole question is one of such interest that it would be well worth while to investigate the matter closely, as it appears to represent a periodicity which is partially inverted as compared with the ordinary type of plant, when the hottest time of the year is time of greatest food accumulation. In this research, however, no attempt was made to investigate the photosynthesis of these plants, so no further explanation is at present possible.

It has been pointed out by various authors that the anatomical structure of the cactus stem must greatly interfere with the absorption of both carbon dioxide and of oxygen. A conservation, therefore, of the carbon would, it is maintained, become a matter of great moment to the plant. Hence it is considered that the retention of the combined carbon in the form of acid is an effective means of this conservation, for in the daytime, even if the acid may not be directly built up again by photosynthesis into plastic food material, it may at least serve as an additional source for carbon dioxide when it is broken down by the sunlight. This may well be the case in a large measure, but it is evident from the results just discussed that photolysis of the acids and the consequent production of carbon dioxide can take place more rapidly than the photosynthesis can, so that under these conditions there must be an actual loss of dry weight.

It has been said above, that in the estimation of the writer the carbon dioxide arising from deacidification which is the result of the further oxidation of the malic acid present is not to be considered as a consequence of a true katabolic process and is not respiratory carbon dioxide. As this point of view is not in agreement with the usual supposition further analysis of the matter is necessary.

It has been stated that the partial oxidation processes which result in the formation of acids, of which malic is undoubtedly the chief, constitute the respiratory phenomena and may be conceived as taking place at all times, although during the day the accumulation of the acid does not ensue because of the effect of light and higher temperature. In the writer's opinion, the substance oxidized to form these acids is the complex of the living protoplasm itself, which in turn no doubt draws upon the reserve food supply to make up the loss. This reserve food supply may very well be in its last analysis the accumulated carbohydrates. That the sugar is directly consumed as such, and that the energy liberated directly from such consumption can be that 
which the plant utilizes he does not regard as a necessary assumption. It may be true that in many eases the amount of earbon dioxide and water produced can be shown to balance with the amount of sugars consumed, but that is no satisfactory proof that the sugar as such is actually split up in the processes of respiration. It is far more likely that it forms combinations with the molecule of the living protoplasm itself and in such connection the actual oxidations and release of energy take place. The union must be an unstable one and with our present incomplete knowledge of the structure of the protein molecule we can hardly postulate more than the probable occurrence of a linkage of the sugar or some derivative of it with the living protoplasm. Its union with the active protoplasm, no matter how tenuous it may be, would afford the means by which the chemical energy released by the oxidation processes is brought in relation with the living substance. Such a picture, crude as it is, can not lead us so far astray from what actually happens as to consider that the energy release takes place simply in the sugars themselves and not in intimate connection with the protoplasm.

To return to the question of the rôle of deacidification in this regard, it may be pointed out that the malic acid present can be broken down in vitro in the presence of light and free oxygen. The acid is presumably present in the cell in the vacuole and when the plant is exposed to the sunlight the deacidification processes very probably take place there, quite removed from the sphere of action of the living protoplasm. The writer is aware that Nathansohn takes a wholly different view and regards the deacidification processes as simply a second step in the katabolic changes, but to the writer such seems improbable in view of all the evidence. The chief reason for assuming that the splitting of the acid is a respiratory process seems to be that such a use of it would be economical from the standpoint of the cactus. It is obviously not necessary to make such an assumption, for the accumulation of acid seems, by general agreement, to be the result of imperfect oxidation which in turn is due to the morphological structure of the cactus. Consequently, whatever of energy there may be from the final oxidation of the acid outside the sphere of protoplasmic activity is simply the result of anatomical peculiarities of the plant, the advantages of which may well outweigh this loss. Any cause which leads to the splitting of the malic acid or its derivatives, whether it be light, high temperature, or prolonged darkness, increases the total evolution of carbon dioxide faster than it does the absorption of oxygen. Consequently, the $\mathrm{CO}_{2} / \mathrm{O}_{2}$ ratio rises and approaches or even exceeds unity. What is considered the normal ratio of these gases in katabolism is thus established, but in reality the approach to the typical gas-relation is not real, for it is supplied simply by the breaking down of the acid. It is to be observed at times when the acidity is high and is falling and is brought about by processes which have no immediate relation with the energy-releasing reactions of the living protoplasm. The true respiratory quotient of the cacti is that which is attained when the acidity is stationary or is rising. At such times there is always less and sometimes very much less carbon dioxide evolved than oxygen absorbed and in consequence the $\mathrm{CO}_{2} / \mathrm{O}_{2}$ ratio is less than unity. This primal fact was established in the original observations of de Saussure, and has been supported by subsequent investigators, but the interpretation adopted here presents the question in a somewhat new light. 







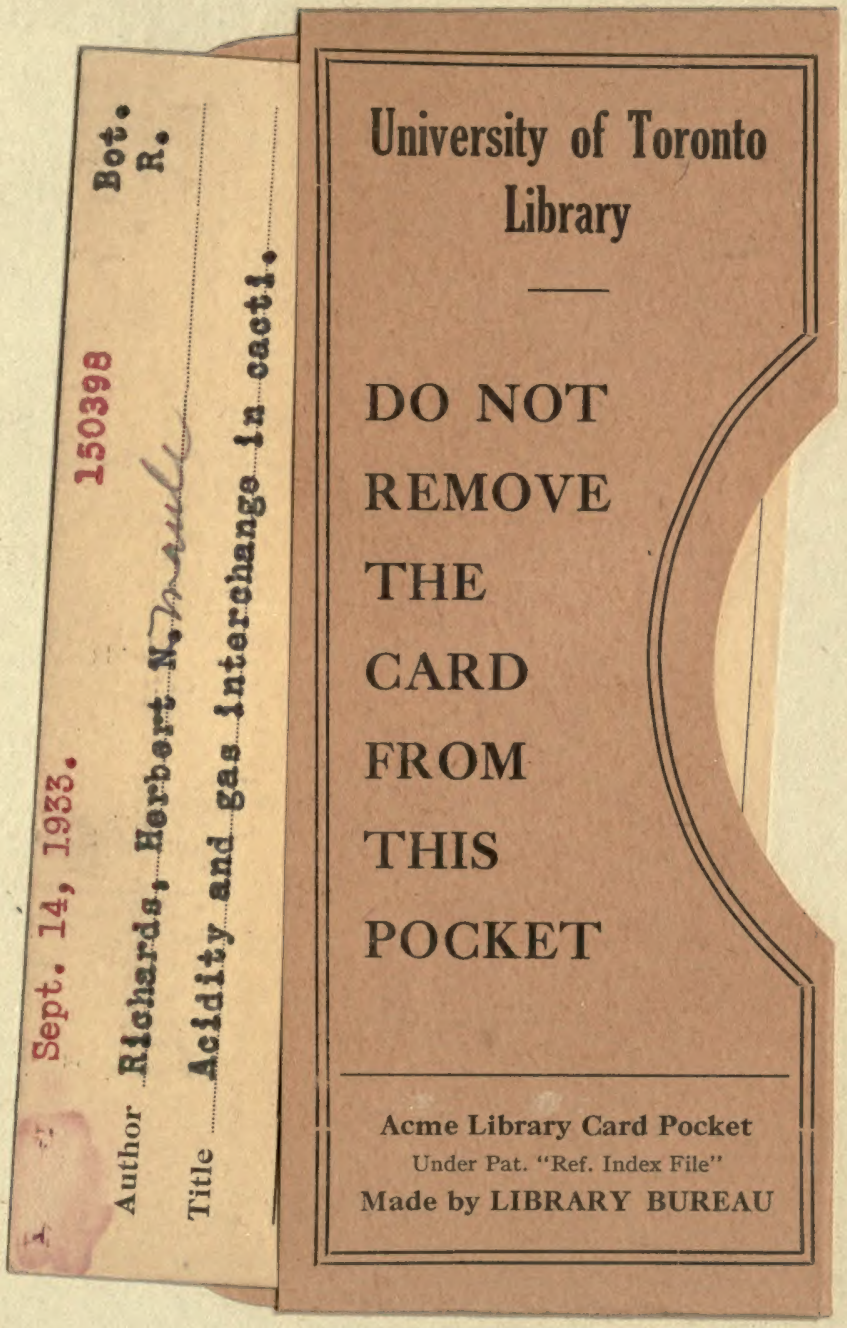


